\author{
UNIVERSIDADE DE SÃO PAULO \\ ESCOLA DE ENGENHARIA DE SÃO CARLOS \\ DEPARTAMENTO DE CIÊNCIA E ENGENHARIA DE MATERIAIS - \\ INTERUNIDADES
}

\title{
RECICLAGEM DE RESÍDUOS DE INDÚSTRIA DE PLACAS CERÂMICAS: UM ESTUDO DE CASO
}

MÁRCIA RODRIGUES DE MORAIS

Orientador: Professor Doutor Eduvaldo Paulo Sichieri

DISSERTAÇÃO DE MESTRADO

SÃO CARLOS

2002 


\author{
UNIVERSIDADE DE SÃO PAULO \\ ESCOLA DE ENGENHARIA DE SÃO CARLOS \\ DEPARTAMENTO DE CIÊNCIA E ENGENHARIA DE MATERIAIS - \\ INTERUNIDADES
}

\title{
RECICLAGEM DE RESÍDUOS DE INDÚSTRIA DE PLACAS CERÂMICAS: UM ESTUDO DE CASO
}

MÁRCIA RODRIGUES DE MORAIS

Dissertação apresentada ao Departamento de Ciência e Engenharia de Materiais Interunidades da Escola de Engenharia de São Carlos, da Universidade de São Paulo, como parte dos requisitos para obtenção do título de Mestre em Ciência e Engenharia de Materiais.

ORIENTADOR: Prof. Dr. Eduvaldo Paulo Sichieri

SÃO CARLOS 
“... e o que nesse momento se revelará aos povos, surpreenderá a todos não por ser exótico, mas pelo fato de poder ter estado oculto, quando terá sido o obvio”.

Caetano Veloso 
A minha mãe e irmãs, por todas as

lutas e conquistas do caminho.

Ao André, por seu amor. 
SUMÁRIO

RESUMO

ABSTRACT

AGRADECIMENTOS

ÍNDICE GERAL

LISTA DE FIGURAS

LISTA DE TABELAS

LISTA DE ABREVIAÇÕES, SIGLAS E SÍMBOLOS 


\section{RESUMO}

Reciclar é a palavra de ordem nos dias atuais. A escassez de matérias-primas, a economia com insumos, a preservação do meio ambiente e o ganho de confiabilidade com a melhora da imagem da empresa são alguns dos aspectos importantes da reutilização dos resíduos. Os lançamentos dos programas de qualidade de processos e produtos fizeram com que as indústrias buscassem meios de produzir mais e melhor, para suportar a competitividade no setor. Porém algumas indústrias brasileiras de revestimento cerâmico ainda produzem elevado índice de resíduos sólidos. Esses índices refletem a deficiência do processo produtivo, o prejuízo com o desperdício de matérias-primas e insumos, e causam o problema do descarte dos resíduos, uma vez que poucas indústrias se aventuram a reciclar, devido à falta de informação técnica. Nos últimos anos, com a crescente preocupação com as questões ambientais e, principalmente, com a implantação dos sistemas de gestão e certificação ambientais, vem sendo observada uma sensível melhora na política ambiental das indústrias de revestimento cerâmico. Mas é necessário, além das políticas, a orientação técnica às empresas, para a adequação de suas atividades em benefício ao meio ambiente. Frente a esses problemas, a presente pesquisa desenvolve um necessário estudo científico, caracterizando e classificando os resíduos, bem como propondo métodos de reutilização baseados em análises experimentais. De acordo com os resultados obtidos, é possível reciclar totalmente os resíduos das lamas do processo de esmaltação e dos resíduos queimados, sem alterar as condições industriais de processamento das placas, obtendo-se, em alguns casos, a melhoria das propriedades mecânicas das peças, recuperando os resíduos como matéria-prima, extinguindo o problema de disposição dos resíduos, e, conseqüentemente, os riscos ao meio ambiente.

Palavras chaves: placas cerâmicas, reciclagem, meio-ambiente. 


\begin{abstract}
Currently recycling is a necessity. The scarcity of raw materials, the economy of resources and labor costs, the preservation of the environment and the gain in confidence with improvement of the company image are some of the important aspects of residue reutilization. The initiation of programs of process and product quality control has made industries searched for ways to produce more and better products in order to be competitive in the sector. However, some Brazilian ceramic tile industries still produce high indices of solid residues. These indices reflect the deficiencies of the production process, losses due to waste of raw materials and resources and labor costs, and cause the problem of the discarding of the residue, since few industries venture to recycle, due to lack technical information. In recent years, with the increasing concern with environmental questions and, mainly with the implantation of environmental management systems and certification, a sensible improvement in the environmental politics of the ceramic tile industries has been observed. However, it is necessary, in addition to these policies, the technical orientation of the companies, to adaptation of its activities in benefit of the environment. Considering these problems, the present research develops a necessary scientific study, characterizing and classifying the residue, as well as proposing methods of reutilization based on experimental analyses. According to the results obtained, it is possible to recycle the mud residues of the enameling and glazing processes, without modifying the industrial conditions of the tile processing. In some cases, obtaining an improvement of the mechanical properties of the pieces, recuperating the residue as raw material, and eliminating the residue disposal problem, and consequently, the risks to the environment
\end{abstract}

Keywords: Tile, recycling, environment. 


\section{AGRADECIMENTOS}

Agradeço a Deus, que me permitiu a execução desse trabalho, como forma de aprendizado da natureza humana, através do aprendizado da natureza das coisas.

Ao professor Dr. Eduvaldo P. Sichieri, pela amizade, apoio e orientação aos trabalhos de pesquisa.

À CAPES/MEC pela bolsa durante todo o período do mestrado.

À Indústria Cerâmica Fragnani - Incefra, em especial ao Marcos Rampo e ao Cristiano, pela disponibilidade durante o desenvolvimento da pesquisa.

À professora Dra. Agnieszka Pawlicka, pelo importante auxílio na pesquisa.

Ao professor Dr. Edward R. Dockal, do DQ da UFSCar, pela amizade, por colocar à disposição o laboratório que coordena e pela revisão do abstract.

Aos técnicos dos institutos IFSC e IQSC da USP, Geraldo Frigo, Cássio, Bento, Edson e Vânia pelo auxílio na obtenção das diversas análises, necessárias à pesquisa.

Aos técnicos dos Departamentos de Geotecnia e de Arquitetura da USP, José Luiz, Sérgio e Paulo, e do DEMA da UFSCar, Walter, Binoto e Luizinho, pelo auxílio na execução das análises.

Ao Marcelo Caridade e Dimas, do Laboratório de Ensaios Físicos do CCB, em Santa Gertrudes, pelo apoio, paciência e auxílio dado à fase inicial do trabalho de pesquisa.

Ao professor Évaldo Spíndola e à Clarice Paschoal, pela realização dos bioensaios.

As secretárias da pós-graduação, pela carinhosa orientação nas questões burocráticas do mestrado.

Aos amigos Érica, Marcos, Maurício, Luciana Calixto, Joaquim, Vanessa, Valdirene, Jorge, Samir, e à Elaine Paris e Fabíola pelo companheirismo e convivência, que deixarão saudades.

À minha família, por todo apoio e amor.

Enfim, quero expressar meus profundos agradecimentos a todas as pessoas que, de alguma maneira, me auxiliaram durante o período desta pesquisa. 


\section{ÍNDICE GERAL}

1. INTRODUÇÃO i

2. OBJETIVOS 4

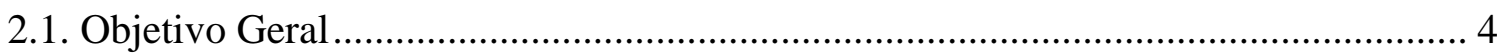

2.2. Objetivos Específicos.......................................................................................... 4

3. REVISÃO BIBLIOGRÁFICA 5

3.1. OS RESÍDUOS INDUSTRIAIS ................................................................... 5

3.1.1. A Reciclagem De Resíduos Cerâmicos................................................................ 12

3.2. ASPECTOS ECONÔMICOS DO SETOR DE PLACAS CERÂMICAS .................. 18

3.2.1. O Mercado Mundial.......................................................................................... 18

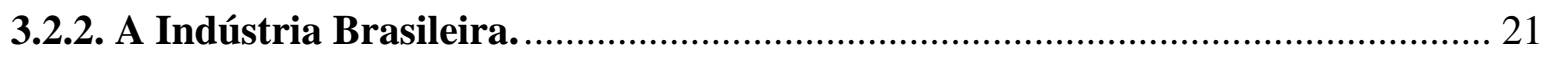

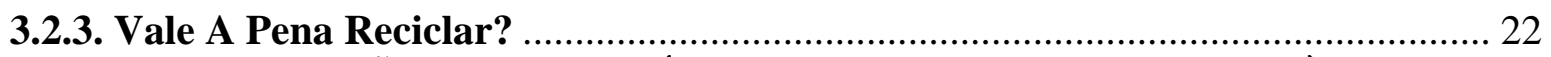

3.3. A LEGISLAÇÃO SOBRE RESÍDUOS INDUSTRIAIS, APLICADA À

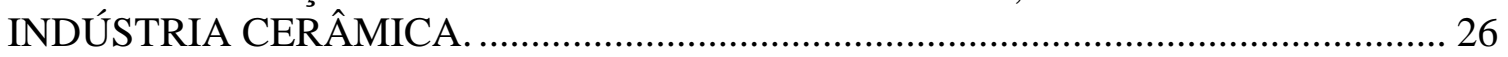

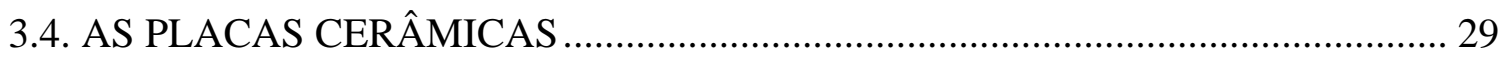

3.4.1. O Processo De Produção Das Placas Cerâmicas …………………………………... 31

3.4.1.1. A preparação da Massa cerâmica ............................................................. 31

3.4.1.2. Conformação da placa cerâmica ............................................................... 31

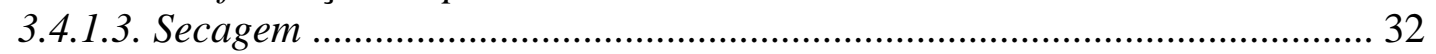

3.4.1.4- Esmaltação ............................................................................................. 34

3.4.1.5- Queima ........................................................................................ 34

4. MATERIAIS E MÉTODOS 38

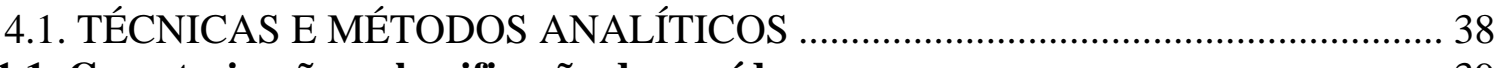

4.1.1. Caracterização e classificação dos resíduos........................................................... 39

4.1.1.1. Determinação da composição mineralógica por $D R X$................................. 39

4.1.1.2. Determinaçãa da composição mineralógica por FTIR. ............................... 39

4.1.1.3. Determinaçãa da composição química ....................................................... 40

4.1.1.4. Determinação da granulometria dos pós..................................................... 40

4.1.1.5. Determinação da Superfície específica....................................................... 41

4.1.1.6. Análises Térmicas .................................................................................. 41

4.1.1.7. Determinação da Toxicidade pelo método de lixiviação................................ 41

4.1.1.8. Determinação da Toxicidade pelo método de Bioteste................................. 42

4.1.2. Determinação dos Ensaios Tecnológicos ………………………………………..... 42

4.1.2.1. Obtenção e queima dos corpos de prova. .................................................. 44

4.1.2.2. Determinação da porcentagem de absorção de água, densidade

aparente e porosidade aparente. .......................................................................... 45

4.1.2.3. Determinação da porcentagem de retração linear..................................... 45

4.1.2.4. Determinação do módulo de ruptura à flexão 3 pontos ................................ 46

5. RESULTADOS E DISCUSSÕES. 47

5.1. CARACTERIZAÇÃO DA MASSA CERÂMICA E DOS RESÍDUOS EM

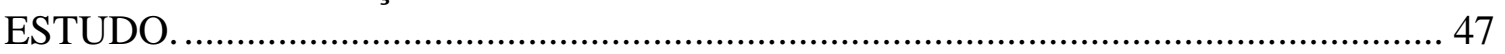

5.1.1. Identificação mineralógica por Difração de Raios X ............................................ 47

5.1.2. Análise de composição mineralógica por espectroscopia de Infravermelho. ..... 51

5.1.2.1. Massa Cerâmica. ....................................................................................... 51

5.1.2.2. Resíduo da ETARI .................................................................................. 55

5.1.2.3. Resíduo Queimado. .............................................................................. 58

5.1.3. Análise da composição química .............................................................................. 59 
5.1.4. Análises Térmicas.

61

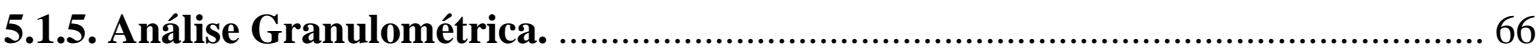

5.1.6. Determinação Da Área Superficial Específica. .............................................. 68

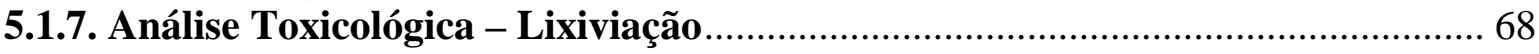

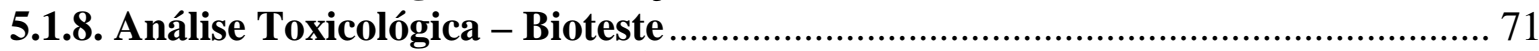

5.2. INCORPORAÇÃO DOS RESÍDUOS NA MASSA CERÂMICA .......................... 72

5.2.1. A determinação da curva de gresificação da massa cerâmica padrão................ 72

5.2.2. Avaliação das propriedades mecânicas de amostras da massa cerâmica

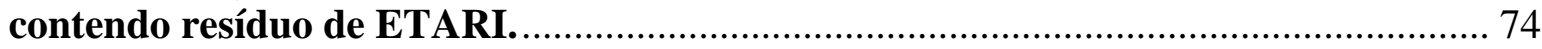

5.2.3. Avaliação das propriedades mecânicas de amostras da massa cerâmica contendo resíduo queimado.

5.2.3.1. A determinação da curva de gresificação da massa cerâmica contendo resíduo queimado fração 1

5.2.3.2. A determinação da curva de gresificação da massa cerâmica contendo resíduo queimado fração 2 .

5.2.4. Avaliação das propriedades mecânicas de amostras da massa cerâmica contendo adição conjunta de resíduos de ETARI e Queimado fração 1. 99 6.0 AVALIAÇÃO TECNOLÓGICA DA INCORPORAÇÃO DOS RESÍDUOS À MASSA CERÂMICA 104

6.1. Resíduos de ETARI.

6.2. Resíduos queimados fração 1 .

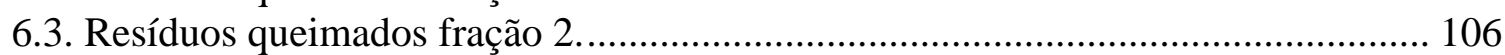

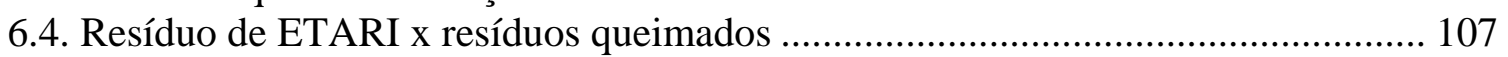

6.5. Adição isolada x adição conjunta dos resíduos..................................................... 113

7. CONCLUSÕES 122

8. SUGESTÕES PARA TRABALHOS FUTUROS124

9. BIBLIOGRAFIA 125 


\section{LISTA DE FIGURAS}

Figura 01a: Ações para implantação da produção limpa. 8

Figura 01b: Ações para implantação da produção limpa. 9

Figura 02: Hierarquia de gerenciamento de resíduos. 10

Figura 03: Técnicas de redução de resíduos na fonte. 11

Figura 04: Técnicas de reciclagem. 12

Figura 05: Processamento usual de placas cerâmicas. 13

Figura 06 Consumo per capita de placas cerâmicas, em 1998.

Figura 07: Composição em peso dos resíduos obtidos no processo de fabricação de placas cerâmicas. $\quad 22$

Figura 08: Composição em peso dos resíduos obtidos no processo de fabricação de placas cerâmicas da Incefra, em 200125

Figura 09: Curva de Bigot 33

Figura 10: Curva de gresificação de placa cerâmica de massa típica. 36

Figura 11: Difratograma de raios-X da massa cerâmica. 48

Figura 12: Difratograma de raios-X da massa cerâmica típica calcinada $500^{\circ} \mathrm{C}$ por 30 minutos. $\quad 48$

Figura 13: Difratograma de raios-X da amostra de resíduo queimado. 49

Figura 14: Difratograma de raios-X do resíduo queimado calcinado em $500^{\circ} \mathrm{C}$ por 30 minutos. $\quad 49$

Figura 15: Difratograma de raios X da amostra de resíduo da ETARI. 50

Figura 16: Difratograma de raios $\mathrm{X}$ da amostra de resíduo da ETARI, calcinada em $500^{\circ} \mathrm{C}$ por 30 minutos. 50

Figura 17: Espectro de FTIR de amostra da massa cerâmica seca em estufa a $100^{\circ} \mathrm{C}$ por 24 horas. 51

Figura 18: Detalhe da região de alta freqüência do espectro de FTIR de amostra da massa cerâmica seca em estufa a $100^{\circ} \mathrm{C}$ por 24 horas. 52

Figura 19: Detalhe da região de freqüência entre $1800 \mathrm{~cm}^{-1}$ e $640 \mathrm{~cm}^{-1}$ do espectro de FTIR de amostra da massa cerâmica seca em estufa a $100^{\circ} \mathrm{C}$ por 24 horas. 53

Figura 20: Detalhe da região de freqüência entre $1200 \mathrm{~cm}^{-1}$ e $200 \mathrm{~cm}^{-1}$ do espectro de FTIR de amostra da massa cerâmica seca em estufa a $100^{\circ} \mathrm{C}$ por 24 horas. 53

Figura 21: Espectro de FTIR de amostra da massa cerâmica seca calcinada em $500^{\circ} \mathrm{C}$ por 30 minutos. 54

Figura 22: Espectro de FTIR de amostra de resíduo de ETARI seca em estufa a $100^{\circ} \mathrm{C}$ por 24 horas. 56

Figura 23: Detalhe da região de freqüência entre $1800 \mathrm{~cm}^{-1}$ e $200 \mathrm{~cm}^{-1}$ do espectro de FTIR de amostra de resíduo de ETARI seca em estufa a $100^{\circ} \mathrm{C}$ por 24 horas. 56

Figura 24: Espectros de FTIR de amostra da massa cerâmica e de resíduo de ETARI, secas em estufa a $100^{\circ} \mathrm{C}$ por 24 horas. $\quad 57$

Figura 25: Espectros de FTIR de amostra da massa cerâmica e de resíduo de ETARI, calcinadas em $500^{\circ} \mathrm{C}$ por 30 minutos. $\quad 57$

Figura 26: Espectro de FTIR de amostra de resíduo queimado, submetida à secagem em $100^{\circ} \mathrm{C}$ por 24 horas e calcinação em $500^{\circ} \mathrm{C}$ por 30 minutos. 58

Figura 27 Espectro de FTIR de amostra mulita comercial. 59

Figura 28: Análise térmica diferencial da massa cerâmica padrão.

Figura 29: Análise térmica diferencial do resíduo da ETARI. 
Figura 30: Análise térmica diferencial dos resíduos queimados frações 1 e 2 . .65

Figura 31: Porcentagem acumulada de grãos retidos versus o diâmetro esférico equivalente $(\mu \mathrm{m})$, das amostras de resíduo da massa cerâmica padrão e dos resíduos de ETARI e queimado frações 1 e 2.66

Figura 32: Curva de gresificação da massa cerâmica sem adições de resíduos. $\quad 73$ Figura 33: Curvas de gresificação da massa cerâmica contendo adições de resíduo ETARI, (a) $1 \%$ em peso, (b) $2 \%$ em peso, (c) $3 \%$ em peso, (d) $4 \%$ em peso, (e) $5 \%$ em peso e (f) $10 \%$ em peso. 75

Figura 34: Temperatura do ponto de gresificação, de amostras de massa cerâmica contendo adições em peso de resíduo ETARI. $\quad 76$

Figura 35-a: Absorção de água de amostras de massa cerâmica contendo adições em peso de resíduo ETARI.

77

Figura 35- $b$ : Absorção de água de amostras de massa cerâmica contendo adições em peso de resíduo ETARI.

Figura 36: Retração linear de amostras de massa cerâmica contendo adições em peso de resíduo ETARI. 78

Figura 37: Porosidade aparente de amostras de massa cerâmica contendo adições em peso de resíduo ETARI.

79

Figura 38: Densidade aparente de amostras queimadas de massa cerâmica contendo adições em peso de resíduo ETARI. 80

Figura 39: Densidade aparente a seco de amostras que foram submetidas à queima de massa cerâmica contendo adições em peso de resíduo ETARI. 81

Figura 40: Módulo de resistência flexão 3 pontos de amostras de massa cerâmica contendo adições em peso de resíduo ETARI.

Figura 41: Módulo de resistência flexão 3 pontos de amostras secas a $100^{\circ} \mathrm{C}$, de massa cerâmica contendo adições em peso de resíduo ETARI. 82

Figura 42: Curvas de gresificação da massa cerâmica contendo adições de resíduo queimado Fração 1, (a) $1 \%$ em peso, (b) $2 \%$ em peso, (c) $3 \%$ em peso, (d) $4 \%$ em peso, (e) $5 \%$ em peso e (f) $10 \%$ em peso. 84

Figura 43: Temperatura do ponto de gresificação de amostras de massa cerâmica contendo adições em peso de resíduo queimado fração 1.85

Figura 44: Absorção de água de amostras de massa cerâmica contendo adições em peso de resíduo queimado fração 1.86

Figura 45: Retração linear de amostras de massa cerâmica contendo adições em peso de resíduo queimado fração 1 .

Figura 46: Porosidade aparente de amostras de massa cerâmica contendo adições em peso de resíduo queimado fração 1.88

Figura 47: Densidade aparente de amostras queimadas de massa cerâmica contendo adições em peso de resíduo queimado fração $1 . \quad 89$

Figura 48: Densidade aparente de amostras secas de massa cerâmica contendo adições em peso de resíduo queimado Fração 1.90

Figura 49: Módulo de resistência flexão 3 pontos de amostras queimadas de massa cerâmica contendo adições em peso de resíduo queimado fração 1.

Figura 50: Módulo de resistência flexão 3 pontos de amostras secas a $100^{\circ} \mathrm{C}$, de massa cerâmica contendo adições em peso de resíduo queimado fração 1.91 
Figura 51: Curvas de gresificação da massa cerâmica contendo adições de resíduo queimado Fração 2, (a) $1 \%$ em peso, (b) $2 \%$ em peso, (c) $3 \%$ em peso, (d) $4 \%$ em peso, (e) $5 \%$ em peso e (f) $10 \%$ em peso.

Figura 52: Temperatura do ponto de gresificação, de amostras queimadas de massa cerâmica contendo adições em peso de resíduo queimado fração 2.

Figura 53: Absorção de água de amostras queimadas de massa cerâmica contendo adições em peso de resíduo queimado fração $2 . \quad 94$

Figura 54: Retração linear seco-queimado de amostras de massa cerâmica contendo adições em peso de resíduo queimado fração 2.95

Figura 55: Porosidade aparente de amostras de massa cerâmica contendo adições em peso de resíduo queimado fração 2. 96

Figura 56: Densidade aparente de amostras queimadas de massa cerâmica contendo adições em peso de resíduo queimado fração 2.96

Figura 57: Densidade aparente de amostras a seco de massa cerâmica contendo adições em peso de resíduo queimado fração $2 . \quad 97$

Figura 58: Módulo de resistência flexão 3 pontos de amostras queimadas de massa cerâmica contendo adições em peso de resíduo queimado fração 2.

Figura 59: Módulo de resistência flexão 3 pontos de amostras secas a $100^{\circ} \mathrm{C}$, de massa cerâmica contendo adições em peso de resíduo queimado fração 2.98

Figura 60: Curvas de gresificação da massa cerâmica contendo adição conjunta de resíduos de ETARI e Queimado Fração 1, (a) 10\% em peso, (b) 3\% em peso. 99

Figura 61: Módulo de resistência flexão 3 pontos de amostras queimadas de massa cerâmica contendo adição conjunta em peso de resíduos de ETARI e Queimado fração $1 . \quad 100$

Figura 62: Absorção de água de amostras queimadas de massa cerâmica contendo adição conjunta em peso de resíduos de ETARI e Queimado fração 1. 101

Figura 63: Retração linear seco-queimado de amostras de massa cerâmica contendo adição conjunta em peso de resíduos de ETARI e Queimado fração 1.102

Figura 64: Densidade aparente de amostras queimadas de massa cerâmica contendo adição conjunta em peso de resíduos de ETARI e Queimado fração 1. 103

Figura 65: Retração linear seco-queimado de amostras de massa cerâmica contendo adições em peso de resíduos de ETARI e queimado frações 1 e 2; (a) $1125^{\circ} \mathrm{C}$, (b) $1100^{\circ} \mathrm{C}$, (c) $1075^{\circ} \mathrm{C}$, (d) $1050^{\circ} \mathrm{C} . \quad 108$

Figura 66: Absorção de água de amostras queimadas de massa cerâmica contendo adições em peso de resíduos de ETARI e queimado frações 1 e 2; (a) $1125^{\circ} \mathrm{C}$, (b) $1100^{\circ} \mathrm{C}$, (c) $1075^{\circ} \mathrm{C}$, (d) $1050^{\circ} \mathrm{C} . \quad 111$

Figura 67: Módulo resistência flexão 3 pontos de amostras queimadas de massa cerâmica contendo adições em peso de resíduos de ETARI e queimado frações 1 e 2; (a) $1125^{\circ} \mathrm{C}$, (b) $1100^{\circ} \mathrm{C}$, (c) $1075^{\circ} \mathrm{C}$, (d) $1050^{\circ} \mathrm{C} . \quad 112$

Figura 68a: Retração Linear de amostras de massa cerâmica queimadas em $1125^{\circ} \mathrm{C}$, contendo adições de modo isolado e conjunto dos resíduos de ETARI e queimados frações 1 e 2. 114

Figura 68b: Retração Linear seco-queimado de amostras de massa cerâmica queimadas em $1100^{\circ} \mathrm{C}$, contendo adições de modo isolado e conjunto dos resíduos de ETARI e queimados frações 1 e $2 . \quad 114$

Figura 68c: Retração Linear seco-queimado de amostras de massa cerâmica queimadas em $1075^{\circ} \mathrm{C}$, contendo adições de modo isolado e conjunto dos resíduos de ETARI e queimados frações 1 e 2.115 
Figura 68d: Retração Linear de amostras de massa cerâmica queimadas em $1050^{\circ} \mathrm{C}$ contendo adições de modo isolado e conjunto dos resíduos de ETARI e queimados frações 1 e 2. 116

Figura 69a: Absorção de água de amostras de massa cerâmica queimadas em $1125^{\circ} \mathrm{C}$, contendo adições de modo isolado e conjunto dos resíduos de ETARI e queimados frações 1 e $2 . \quad 116$

Figura 69b: Absorção de água de amostras de massa cerâmica queimadas em $1100^{\circ} \mathrm{C}$, contendo adições de modo isolado e conjunto dos resíduos de ETARI e queimados frações 1 e $2 . \quad 117$

Figura 69c: Absorção de água de amostras de massa cerâmica queimadas em $1075^{\circ} \mathrm{C}$, contendo adições de modo isolado e conjunto dos resíduos de ETARI e queimados frações 1 e 2. 117

Figura 69d: Absorção de água de amostras de massa cerâmica queimadas em $1050^{\circ} \mathrm{C}$, contendo adições de modo isolado e conjunto dos resíduos de ETARI e queimados frações 1 e $2 . \quad 118$

Figura 70a: Módulo de resistência à flexão 3 pontos de amostras queimadas em $1125^{\circ} \mathrm{C}$, de massa cerâmica contendo adições de modo isolado e conjunto dos resíduos de ETARI e queimados frações 1 e 2.

Figura 70b: Módulo de resistência à flexão 3 pontos de amostras queimadas em $1100^{\circ} \mathrm{C}$, de massa cerâmica contendo adições de modo isolado e conjunto dos resíduos de ETARI e queimados frações 1 e $2 . \quad 119$

Figura 70c: Módulo de resistência à flexão 3 pontos de amostras queimadas em $1075^{\circ} \mathrm{C}$, de massa cerâmica contendo adições de modo isolado e conjunto dos resíduos de ETARI e queimados frações 1 e $2 . \quad 120$

Figura 70d: Módulo de resistência à flexão 3 pontos de amostras queimadas em $1050^{\circ} \mathrm{C}$, de massa cerâmica contendo adições de modo isolado e conjunto dos resíduos de ETARI e queimados frações 1 e $2 . \quad 120$ 


\section{LISTA DE TABELAS}

Tabela 01: Resíduos gerados em função do processamento cerâmico. 14

Tabela 02: Análise química média da lama das indústrias de placas cerâmicas da região de Castellón, Espanha. 15

Tabela 03: Balanço mundial dos principais países economicamente ativos no setor de cerâmica de revestimento. 20

Tabela 04: Produção de Resíduos na Incefra em 2001. 24

Tabela 05: Principais características dos procedimentos normalizados para os ensaios de lixiviação nos Estados Unidos, Comunidade Européia e Brasil. 27

Tabela 06: Regulamentação das características do lixiviado. 28

Tabela 07: Classificação das placas cerâmicas. 30

Tabela 08a: Composição das misturas da massa cerâmica padrão contendo adições isoladas de resíduo de ETARI. $\quad 43$

Tabela 08b: Composição das misturas da massa cerâmica padrão contendo adições isoladas de resíduo Queimado Fração 1. 43

Tabela 08c: Composição das misturas da massa cerâmica padrão contendo adições isoladas de resíduo Queimado Fração 2. 43

Tabela 09: Composição das misturas da massa cerâmica padrão contendo adições simultâneas dos resíduos de ETARI e queimado. 44

Tabela 10: Análises de EDX de amostras cerâmicas $\quad 60$

Tabela 11: Picos característicos presentes nos termogramas da massa cerâmica e do resíduo de ETARI. 64

Tabela 12: Distribuição granulométrica das amostras de massa cerâmica e resíduos da ETARI e queimados. 67

Tabela 13: Análise de lixiviação da massa cerâmica e dos resíduos. 68

Tabela 14: Análise de lixiviação da massa cerâmica contendo resíduos. 70

Tabela 15: Teste de toxicidade das amostras BIOT 1R, BIOT 2R, BIOT 3R e BIOT 4R para Daphnia similis (Cladocera). $\quad 72$

Tabela 16: Porcentagens recomendadas de adição de resíduo de ETARI à massa cerâmica, em função da temperatura de queima. 105

Tabela 17: Porcentagens recomendadas de adição de resíduo queimado fração 1 à massa cerâmica, em função da temperatura de queima. 106

Tabela 18: Classificação das amostras cerâmicas contendo resíduos queimados frações 1, 2, e de ETARI. 110

Tabela 19: Recomendação geral de uso dos resíduos queimados frações 1, 2, e de ETARI por incorporação isoladamente à massa cerâmica padrão. 113 


\section{LISTA DE ABREVIAÇÕES, SIGLAS E SÍMBOLOS}

$\rho_{\mathrm{L}}$ - Densidade do meio líquido

AA - Absorção de água aparente (\%)

ANFACER - Associação Nacional dos Fabricantes de Cerâmica

ASCER - Associación Española Fabricantes de Azulejos y Pavimentos Cerámicos

ATD - Análise Térmica Diferencial

$\mathrm{CE}_{50-48 \mathrm{H}}$ - Concentração Efetiva que causa efeito adverso em $50 \%$ da população

CsI - Iodeto de Césio

CTCV - Centro de Tecnologia de Cerâmica e Vidro

DA - Densidade aparente $\left(\mathrm{g} / \mathrm{cm}^{3}\right)$

DRX - Difração de Raios X

EDX - Espectroscopia Dispersiva de Raios X

ETARI - Estação de Tratamento de Águas Residuais Industriais

FTIR - Infravermelho com Transformada de Fourrier

ISO - International Standards Organization

ITC - Instituto de Tecnologia Cerâmica

MRF - Módulo Resistência à Flexão 3 pontos $\left(\mathrm{Kgf} / \mathrm{cm}^{2}\right)$

$\mathrm{P}+\mathrm{L}$ - Produção mais Limpa

PA - Porosidade Aparente (\%)

pH - Potencial Hidrogeniônico

PL - Produção Limpa

RL - Retração linear (\%)

RTP - Resíduo Tóxico e Perigoso

SGA - Sistema de Gestão Ambiental 


\section{INTRODUÇÃO}

A pesquisa que se apresenta iniciou-se, motivada pela observação do modo de produção das indústrias brasileiras de placas cerâmicas, analisando-se os problemas enfrentados nos últimos anos, com relação à questão de gerenciamento de qualidade e de ordem econômica, principalmente a da questão ambiental, onde os resíduos produzidos, devido à sua natureza, apontam para uma possível utilização no processo de produção cerâmico, revelando o potencial econômico desses materiais, bem como uma solução para os problemas ambientais que normalmente geram.

Mediante o fato das indústrias cerâmicas da região de Santa Gertrudes, no estado de São Paulo, utilizarem o processo via seco e matérias primas básicas de procedência da mesma formação geológica, foi escolhida uma indústria de grande porte para ser objeto de um estudo de caso, permitindo, dessa forma, que o pólo cerâmico possa utilizar os resultados como referência para as questões sobre reciclagem dos resíduos sólidos cerâmicos que surgirem em virtude da problemática desses resíduos.

Em visita à empresa INCEFRA - Indústria Cerâmica Fragnani Ltda., efetuouse a coleta de amostras da massa cerâmica utilizada na fabricação de placas cerâmicas esmaltadas, bem como dos resíduos sólidos, obtido por sedimentação, após tratamento das águas residuárias da linha de produção e peças queimadas fora de especificação, necessárias ao procedimento da pesquisa laboratorial.

\section{A Empresa}

A Indústria Cerâmica Fragnani - Incefra, está sediada no município de Cordeirópolis, no estado de São Paulo, região muito próspera em virtude da proximidade de grandes centros urbanos e da presença de matérias primas nobres essenciais para a produção de produtos cerâmicos de alta qualidade. Foi fundada em 13 de janeiro de 1971 com o objetivo inicial de produzir tijolos furados e telhas para atender o mercado nacional, numa área de $1000 \mathrm{~m}^{2}$.Com o passar do tempo a empresa especializou-se na produção de telhas esmaltadas coloridas, que tiveram grande aceitação do mercado consumidor. Em 1988, com a visão voltada ao 
crescente mercado consumidor de placas cerâmicas, a empresa empenhou-se na construção de uma unidade de alta tecnologia, com capacidade de produção de $1.800 .000 \mathrm{~m}^{2} /$ ano de placas cerâmicas esmaltadas. Tal visão de mercado mostrou-se tão acertada que, já em 1993, a produção saltou para $5.400 .000 \mathrm{~m}^{2} / a n o$. A partir de 1994, buscando cada vez mais qualidade e beleza a um preço acessível em seus produtos, a empresa investiu em reciclagem, treinamento e melhoria de vida de seus funcionários, medida esta que resultou num aumento de produtividade de 20\%, elevando a produção para $6.500 .000 \mathrm{~m}^{2} /$ ano. Hoje, a Incefra possui uma produção mensal de $1.300 .000 \mathrm{~m}^{2} /$ mês, o que a caracteriza como a maior planta fabril do país na produção de placas cerâmicas pelo processo "via seca”, em seis linhas de produção, numa área construída de $400.000 \mathrm{~m}^{2}$, com 320 colaboradores diretos. Os produtos da INCEFRA possuem certificados Inmetro-CCB pela NBR 13.818 (produtos), recente indicação para a certificação ISO 9002 (sistemas) e constante desenvolvimento de novos produtos.

Essas características agregadas têm permitido que os produtos INCEFRA sejam comercializados em todo o Brasil e em vários países das Américas do Norte, Central e do Sul, bem como países do Caribe e África.

Para tornar seus produtos mais atrativos e ganhar o mercado consumidor da região nordeste brasileira, a INCEFRA optou por instalar duas novas unidades fabris no estado da Bahia, que se destaca pela riqueza das matérias-primas necessárias à obtenção das placas cerâmicas, além de atrativos como a viabilização de gás natural, energia elétrica e mão-de-obra qualificada pelas instituições de ensino técnico e superior locais.

A INCEFRA possui a sua própria jazida para a obtenção de matéria-prima necessária à preparação da massa cerâmica utilizada na fabricação de seus produtos, localizada a cerca de $2 \mathrm{~km}$ da unidade industrial. Esta matéria-prima “in natura” é extraída por meio da técnica de escarificação simples em lavra a céu aberto. Após a extração, o material é desaglomerado, homogeneizado e pré-secado em pátio, sendo, então, submetido aos processos de secagem final em secadores rotativos, moagem e umidificação para poder ser processado industrialmente na preparação das placas cerâmicas. De acordo com a empresa, as etapas de mineração propriamente ditas e posterior homogeneização e pré-secagem em pátio, são realizadas dentro de 
procedimentos específicos que visam a minimização do impacto ambiental, sendo respeitadas todas as exigências legais estipuladas pelos órgãos ambientais competentes como a CETESB, DPRN, IBAMA, etc.

Para a nova unidade de moagem, que está em fase de instalação e que atenderá $100 \%$ da demanda produtiva, está sendo implantada uma barreira vegetal que, além de contribuir para o aspecto visual do local, terá a função de reter de possíveis particulados sólidos que possam ser gerados nas etapas de secagem, carga e descarga do material do pátio.Com constante preocupação sobre a eficiência produtiva e o meio ambiente, a empresa, gentilmente, se prontificou em colaborar com a presente pesquisa, o que possibilitou que seus resíduos se tornassem objeto desse estudo de caso. 


\section{OBJETIVOS}

\subsection{Objetivo Geral}

O objetivo deste trabalho é proporcionar às indústrias brasileiras de revestimentos cerâmicos, aos órgãos públicos de controle ambiental e demais profissionais, mediante um estudo de caso, uma pesquisa científica que possibilite a diminuição do impacto ambiental associado ao descarte dos resíduos sólidos produzidos nas indústrias de placas cerâmicas, quando este ocorre de forma inadequada.

\subsection{Objetivos Específicos}

Este trabalho propõe um estudo de caso para avaliar a situação atual de uma empresa de placas cerâmicas da região de Santa Gertrudes, em relação aos resíduos produzidos, à possibilidade de reutilização dos resíduos crus e queimados, bem como à sua relação com o meio ambiente. Propõe, também, criar vertedouros e controladores que permitam a eliminação adequada dos resíduos que não possam ser reciclados. 


\section{REVISÃO BIBLIOGRÁFICA}

\subsection{OS RESÍDUOS INDUSTRIAIS}

A revolução industrial, por volta de 1750, estabeleceu um marco divisório na questão ambiental do planeta Terra. Anteriormente à revolução era praticada a “teoria da diluição”, ou seja, todo o resíduo era lançado na natureza, que o assimilava até a sua total degradação. Com a revolução industrial o ritmo de geração e descarte de resíduos no meio ambiente aumentou significativamente, fazendo com que a capacidade de regeneração da Terra não fosse capaz de acompanhar o ritmo de poluição.

Assim, a percepção dessas interferências ambientais e suas conseqüências têm forçado uma mudança na abordagem das questões ambientais. As legislações ambientais foram instituídas para tentar controlar a degradação do meio ambiente, porém esse processo é gradual e encontra resistências. KINLAW (1997) estabelece que as resistências vêm, principalmente, do:

- hábito de perceber a natureza como um inimigo a vencer e também como um provedor de infinita generosidade, que deve se curvar à vontade humana;

- hábito de ver o meio ambiente como algo fragmentado e os seus problemas como pequenos pedaços, separados e facilmente compreensíveis.

Entretanto o que se tem visto atualmente é que estas duas formas de pensamento mostraram-se muito limitadas.

Os processos industriais são as principais fontes de geração de resíduos perigosos. Além de serem grandes causadores de impactos ambientais, muitas vezes de difícil identificação e demorada remediação. Para KINLAW (1997), além das leis ambientais cada vez mais punitivas, o crescimento e a organização de grupos ambientalistas e uma maior conscientização dos consumidores são os principais fatores de mudança da visão estratégica das indústrias.

A importância da conservação ambiental e do desenvolvimento sustentável, visando garantir a qualidade de vida do ser humano está cada dia mais presente no 
cotidiano das indústrias, cujo setor produtivo é responsável pelas ações de danos e de reparo ao meio ambiente.

De acordo com CARVALHO et al (2000), um aspecto social da organização industrial, no seu sentido amplo, é qualquer elemento pertinente à sua forma de conduta e atitudes, a seus processos, à sua operação, à suas atividades em geral e a seus produtos e serviços que afetam ou que podem afetar, direta ou indiretamente, real ou potencialmente, a qualidade de vida, os meios de vida e a forma de organização de seus empregados e da população em geral.

Sendo um impacto social qualquer mudança na qualidade de vida humana, o processo de determinação desses impactos vale-se de análises e estudos preexistentes de riscos ocupacionais físicos, químicos e biológicos, ergonômicos e de acidentes ou mecânicos.

A correlação entre os impactos e aspectos sociais é que, enquanto o impacto se caracteriza por uma mudança, como por exemplo, uma redução da quantidade e da qualidade da fauna aquática dos córregos e igarapés adjacentes, comprometendo o sustento das comunidades vizinhas, o aspecto social é a causa ou o elemento da mudança. Nesse exemplo, o aspecto é o passivo devido a efluentes líquidos contaminados lançados pela empresa e ao assoreamento provocado na época de chuva.

Desse modo, a indústria adquiriu uma responsabilidade social, uma vez que atua direta ou indiretamente sobre a vida humana. Nos últimos anos, pela constatação de que o meio ambiente estava sendo rapidamente degradado, com previsões nada otimistas para a qualidade de vida do ser humano, é que se passou a pensar em conservação ambiental e desenvolvimento sustentável.

O que se observa é que os empresários ainda não atentaram ao fato de que suas indústrias possuem essa responsabilidade social, mas já demonstram a preocupação em resolver o problema da degradação ambiental, utilizando de sistemas de gestão (SGA) e certificação ambientais.

De acordo com REIS (1996), a preocupação com a qualidade do meio ambiente tem resultado em um aprimoramento das SGAs das empresas, em busca de um melhor desempenho ambiental. 
Desta forma, as normas da série ISO 14000 surgem para auxiliar o desenvolvimento dos SGAs eficientes, vindo a padronizar os sistemas de gestão ambiental das empresas.

Os chamados sistemas de produção limpa (PL) e produção mais limpa (P+L), juntamente com as normas de certificação série ISO 14000 são os mais utilizados na atualidade. Esses sistemas compreendem estratégias de prevenção ambiental integrada a processos, produtos e serviços, com o objetivo de aumentar a eficiência e reduzir riscos para o meio ambiente e, conseqüentemente, para a humanidade.

Com a redução de resíduos e o aumento na eficiência do processo produtivo, além da preservação ambiental, os benefícios econômicos são muito atrativos, despertando o interesse cada vez maior das empresas.

Os princípios básicos da produção mais limpa são a avaliação de todo o ciclo de vida do produto ou serviço, a minimização da geração de resíduos e/ou a busca de alternativas que possam transformar esses resíduos e a máxima economia do consumo de água e energia.

Os princípios básicos da produção limpa compreendem os três itens anteriores, acrescidos da precaução de produtos com riscos ao homem e ao meio ambiente, buscando substituí-los por outros mais seguros e do controle democrático da informação, possibilitando aos setores de controle da sociedade o acesso às informações relacionadas à segurança e ao uso de produtos e dos processos de produção. Em termos práticos, a PL prevê ações como as descritas nas figuras 01a e 01b.

Segundo João Salvador Furtado apud PRODUÇÃo LIMPA E PRODUÇÃO MAIS LIMPA (2000)ㅜㅜ, “a empresa que decidir implantar a PL ou P+L não precisa, necessariamente, obter a certificação ISO 14001, porém o empresário que decidir conquistar a norma ambiental está preparadíssimo para implantar a PL ou P+L. Além disso, as empresas que se apresentam como campeãs na área ambiental objetivam, principalmente, estabelecer uma política de meio ambiente definida e,

1 FURTADO, J. S.; apud PRODUÇÃO LIMPA E PRODUÇÃO MAIS LIMPA; Revista Meio Ambiente Industrial - RIMAI; ano IV-nº25 - 26를 ed.; 74 -82; jul/ago, 2000. 
conseqüentemente, mudar o sistema de comunicação para falar com investidores internacionais".

De outro lado, a contribuição fiscalizadora do órgão ambiental vem sendo complementada por ações desenvolvidas em parceria e com a participação voluntária das indústrias, de prevenção à poluição que visam evitar/minimizar a geração de resíduos na fonte e que, conseqüentemente, ajudam as empresas a cumprir a legislação, como é o caso da Cetesb (agência Piracicaba), que desenvolve projetos na área de prevenção á poluição no pólo cerâmico de Santa Gertrudes.

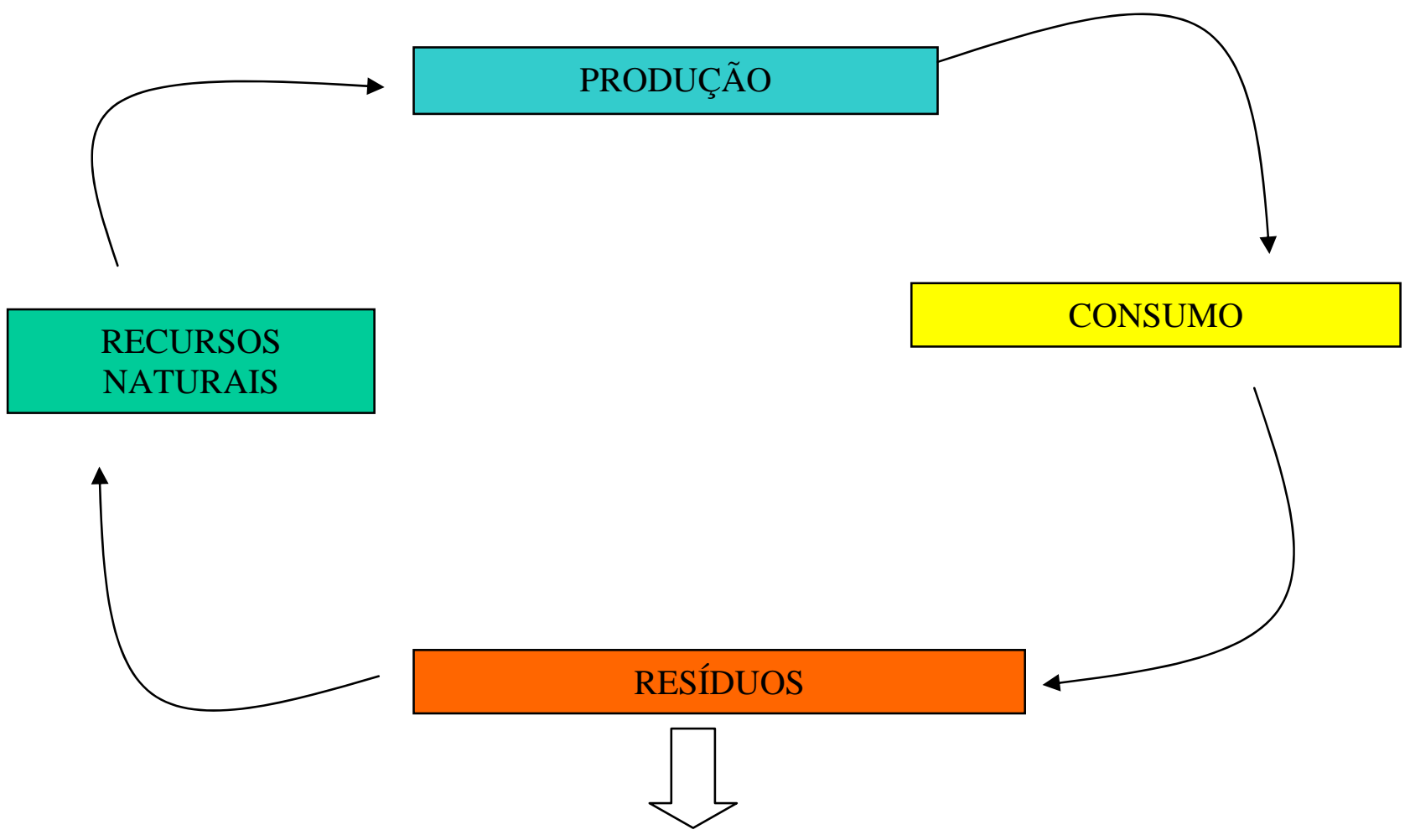

\section{MEIO AMBIENTE}

DEGRADAÇÃO

AMBIENTAL

Figura 01a: Ações para implantação da produção limpa.

FONTE: Furtado apud PRODUÇÃO LIMPA E PRODUÇÃO MAIS LIMPA (2000). 
1. Mudanças nas matérias-primas: redução ou eliminação do uso de matériasprimas perigosas, como pigmentos com metais pesados, tintas e solventes clorados. Uso de matérias-primas de melhor qualidade para evitar contaminantes no processo. Uso de materiais reciclados para criar mercado para estes produtos.

2. Otimização da produção e boas práticas de organização: redução de perda de matérias-primas, produtos e energia devido a vazamentos, derramamentos, etc. Programação da produção de modo a reduzir a necessidade de limpeza do equipamento. Melhorar a administração do estoque de matérias-primas e produtos para evitar vencimento do prazo de validade. Realizar manutenção preventiva para diminuir o tempo de parada dos equipamentos. Evitar misturar diferentes tipos de resíduos.

3. Reutilização interna: Reciclar dentro da empresa águas residuais e outros materiais. Recuperar energia onde for possível. Encontrar usos menos críticos para matérias-primas fora de especificações. Criar subprodutos com resíduos gerados.

4. Mudanças de tecnologia: Mudar equipamento, layout ou processo para melhorar a eficiência do processo, evitando a geração de resíduos e produtos fora de especificações.

5. Mudanças no produto: Reformulação de produtos para reduzir o impacto ambiental, aumentar a vida útil dos produtos e facilitar a reciclagem, eliminando partes não recicláveis, projetando-os para serem facilmente desmontáveis e reciclados. Diminuição de embalagens desnecessárias.

Figura 01b: Ações para implantação da produção limpa.

FONTE: Furtado apud PRODUÇÃO LIMPA E PRODUÇÃO MAIS LIMPA (2000).

Para SALEJ (1999), as formas de produções limpas baseadas em conceitos corretos ou eliminação, substituição, minimização e reciclagem (material e energético) de resíduos causadores de impactos ambientais são conseqüências do processo de globalização da economia.

A US EPA in COMELLA \& RITTMEYER apud CAPELINI (1999) ${ }^{2}$ estabelece uma hierarquia para o gerenciamento de resíduos considerando os

2 CAPELINI, M.; Proposta de minimização de resíduos em indústria de acabamento de metais: estudo de caso; São Carlos; 1999. Dissertação (mestrado), Escola de Engenharia de São Carlos, Universidade de São Paulo. 
benefícios ambientais de cada método. A figura 02 apresenta a hierarquia de gerenciamento de resíduos e suas respectivas definições.

Redução na fonte: significa a redução ou eliminação de resíduos na fonte, geralmente dentro do processo. As medidas incluem modificações no processo, substituição de matéria-prima, melhora na purificação da matéria-prima, melhora nas práticas de manejo e de gerenciamento, no aumento da eficiência do maquinário e reciclagem dentro do processo. A redução na fonte é qualquer atividade que reduza a quantidade de resíduos existentes no processo. Reduzir na fonte é prevenir a geração de resíduos.

Reciclagem: é o uso ou reuso de resíduos perigosos como um efetivo substituto para um produto comercial, ou como ingrediente ou matéria-prima em um processo industrial. Isto inclui a recuperação de frações de contaminantes de um resíduo ou remoção destes para que o resíduo possa ser utilizado. Reciclagem pode incluir o uso de resíduos como combustível suplementar ou substituto. No entanto, processos nos quais a eficiência média de energia seja menor que 60\%, são considerados incineração (tratamento) e não recuperação de energia (reciclagem).

Tratamento: é qualquer método, técnica ou processo que mude as características físicas, químicas ou biológicas de um resíduo perigoso, para neutralizá-lo, recuperar energia ou recursos materiais, ou para devolvê-lo ao meio como resíduo não perigoso ou menos perigoso, seguro para manejo, apto a ser recuperado, estocado, ou reduzido em volume.

Disposição: é a deposição de resíduos perigosos dentro ou sobre um terreno ou água, de maneira que este resíduo ou seus constituintes possam ser lançados na atmosfera, ou depositados em corpos hídricos, inclusive águas subterrâneas.

Figura 02: Hierarquia de gerenciamento de resíduos.

Fonte: COMELLA \& RITTMEYER (1990), p.71 apud Capelini, M. ${ }^{[7]}$

O combate à degradação ambiental consiste em medidas de curto e longo prazo. As medidas em curto prazo são, geralmente, mais simples e de baixo custo, porém apresentam resultados menos efetivos que as medidas em longo prazo. São formas de minimização de resíduos a redução na fonte e a reciclagem.

As técnicas de redução de resíduos na fonte implicam em mudanças no produto e/ou no processo, conforme apresenta a Figura 03. 


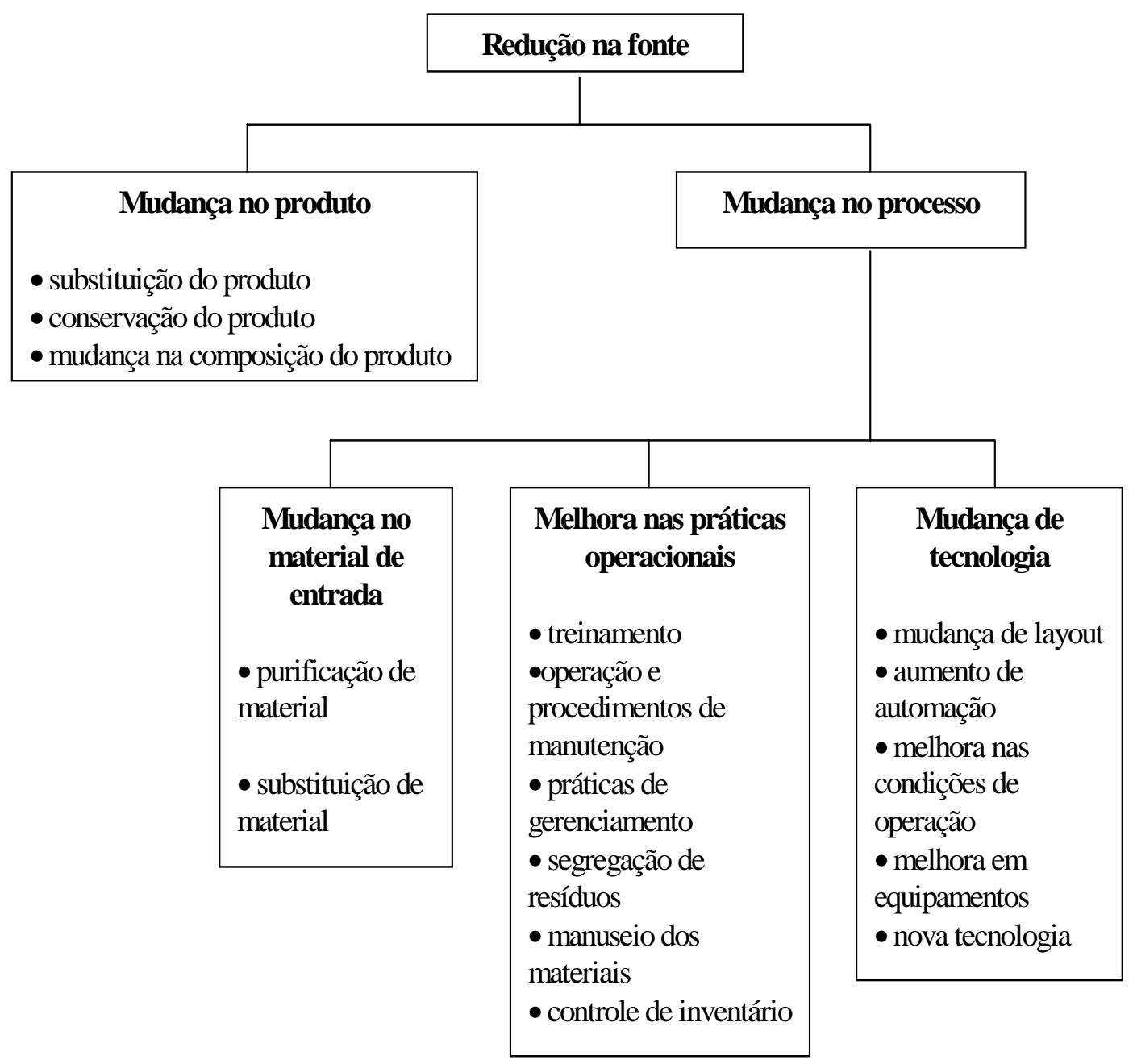

Figura 03: Técnicas de redução de resíduos na fonte.

FONTE: PPW (1993), p.5 apud CAPELINI (1999).

A reciclagem de resíduos é uma técnica implantada há tempo e é bastante praticada em muitos setores industriais. De acordo com Vernier (1994), a recuperação de certos “materiais-dejetos” é, há muito tempo, praticada na indústria, principalmente em quatro setores: metais ferrosos, metais não-ferrosos, papéis e 
vidros. Estabelecem, aliás, dois problemas: saber recuperar os materiais usados e saber reutilizar os materiais recuperados.

As técnicas de reciclagem constituem em uso e reuso e recuperação, conforme apresentado na Figura 04.

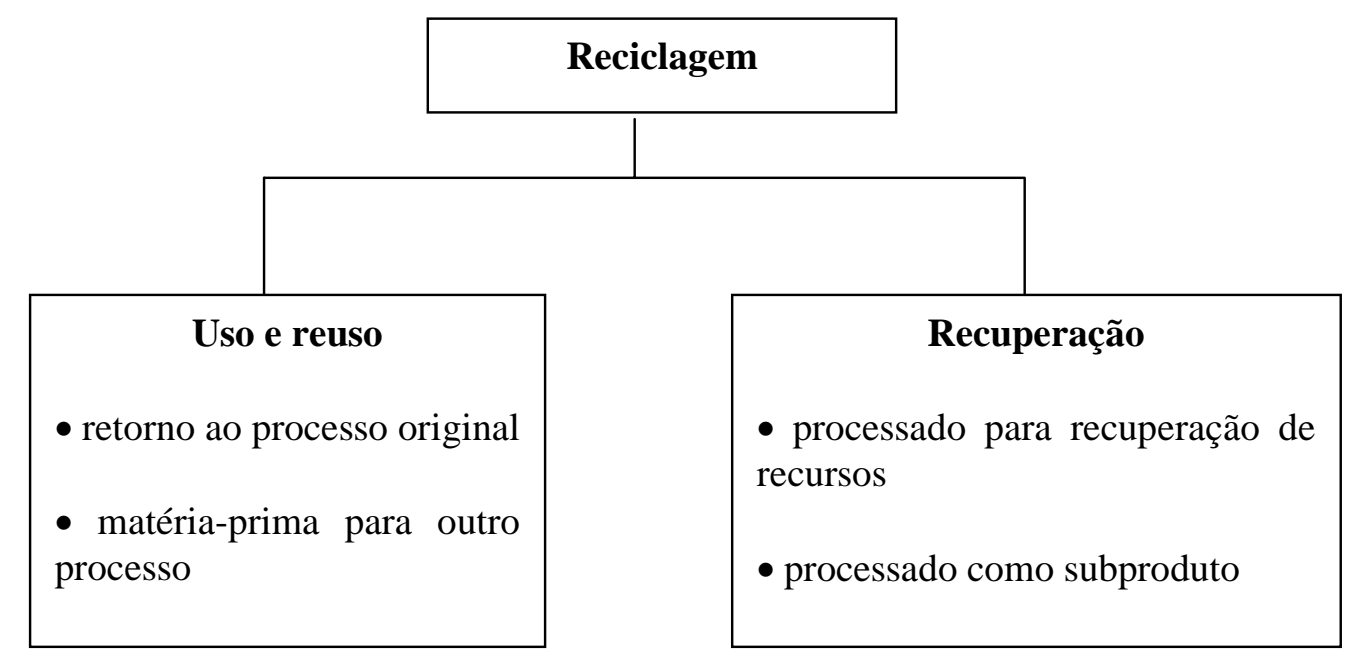

Figura 04: Técnicas de reciclagem.

FONTE: CHEREIINOFF \& KING (1991), p.66. (modificado) apud CAPELINI (1999).

O uso e reuso constitui a volta do resíduo como matéria-prima para o próprio ou em outro processo. A recuperação consiste na recuperação de um composto do resíduo para que seja utilizado no próprio, ou em outro processo.

SCHIMIT e KODUCULAN (1985) consideram a reciclagem de resíduos industriais dependente de fatores tecnológicos e econômicos, sendo este último a limitação mais importante, uma vez que as técnicas de reciclagem são caras.

\subsubsection{A Reciclagem De Resíduos Cerâmicos.}

O conhecimento detalhado de todas as etapas do processo produtivo de revestimento cerâmico é de vital importância para a avaliação precisa dos aspectos 
econômicos e ambientais. FIGUEREDO FILHO et al. (1999), construíram matrizes de interação processo produtivo x meio ambiente, adaptadas ao processo de produção de revestimentos cerâmicos, pelas quais se pode estabelecer, mesmo na ausência de dados experimentais, os principais pontos de geração de resíduos, apresentados na tabela 01 .

A figura 05 apresenta um modelo usual de produção de placas cerâmicas na indústria brasileira.

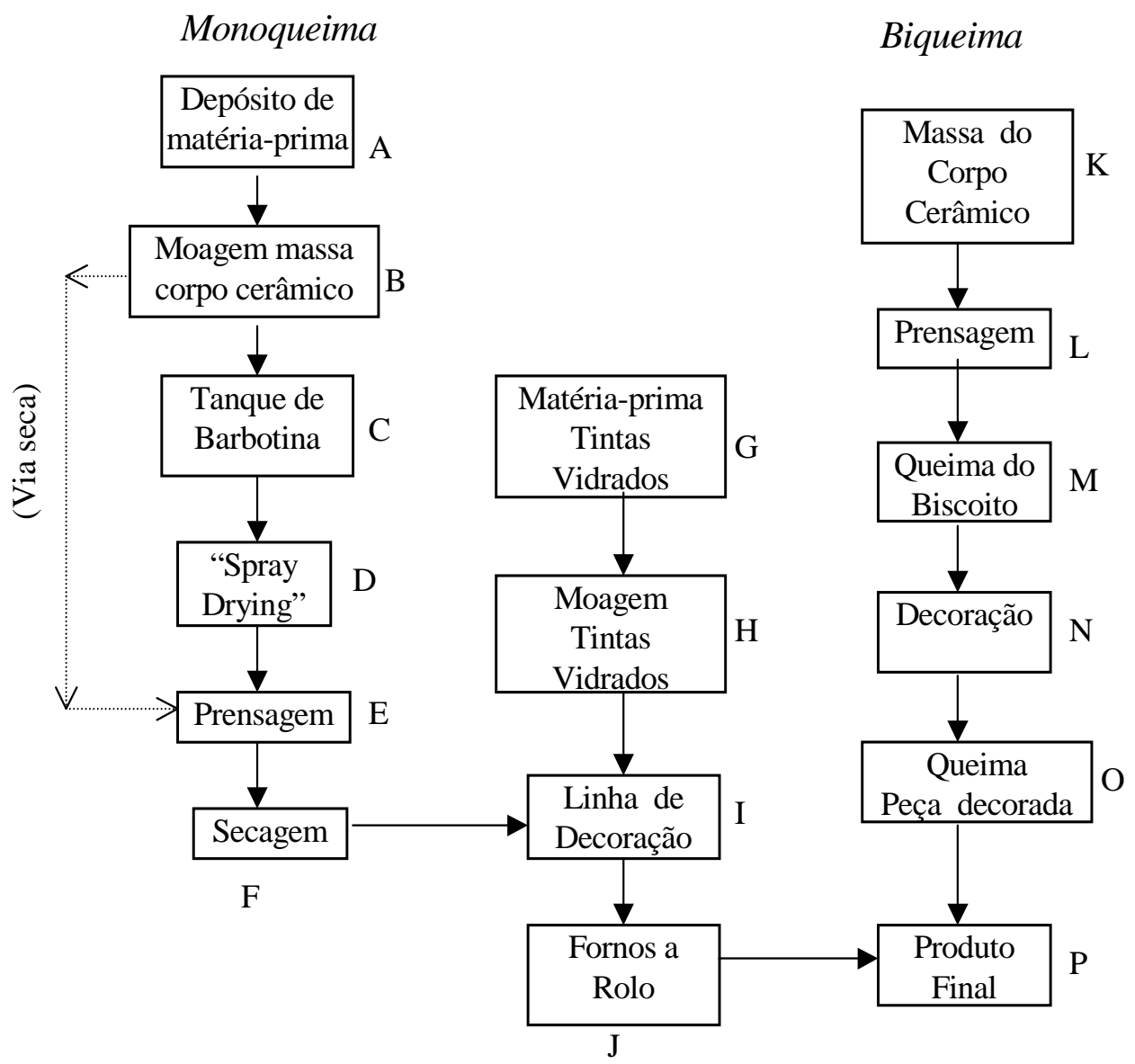

Figura 05: Processamento usual de placas cerâmicas.

FONTE: FIGUEREDO FILHO et al. (1999). 
Tabela 01: Resíduos gerados em função do processamento cerâmico.

FONTE: FIGUEREDO FILHO et al. (1999).

\begin{tabular}{|c|c|c|}
\hline ETAPAS & MATÉRIAS-PRIMAS/INSUMOS & RESÍDUOS GERADOS \\
\hline A & Argila; Filito; Taguá; Talco; Feldspato & Partículas em Suspensão \\
\hline B & Água; Massa Corpo Cerâmico; Óleo & Efluente Líquido; Sedimentos \\
\hline $\mathrm{C}$ & Água; Massa do Corpo Cerâmico & Resíduos do Peneiramento da Barbotina \\
\hline $\mathrm{D}$ & Gás Natural; Massa do Corpo Cerâmico & Partículas em Suspensão; Gases de Exaustão \\
\hline $\mathrm{E}$ & $\begin{array}{c}\text { Energia; Óleo; Massa Cerâmica } \\
\text { Atomizada }\end{array}$ & Peças cerâmicas; Partículas em Suspensão \\
\hline $\mathbf{F}$ & $\begin{array}{c}\text { Gás Natural; Massa Cerâmica } \\
\text { Atomizada }\end{array}$ & Partículas em Suspensão; Gases de Exaustão \\
\hline G & Esmaltes; Corantes; Engobes & Partículas em Suspensão \\
\hline $\mathrm{H}$ & $\begin{array}{c}\text { Água; Esmaltes; Corantes; Engobes; } \\
\text { Óleo }\end{array}$ & Efluente Líquido; Sedimentos \\
\hline I & $\begin{array}{c}\text { Peças Cerâmicas; Massa Decoração; } \\
\text { Água }\end{array}$ & $\begin{array}{c}\text { Efluente Líquido; Sedimentos; Partículas } \\
\text { Suspensão; Peças Cerâmicas }\end{array}$ \\
\hline $\mathrm{J}$ & Gás Natural; Energia; Peças Cerâmicas & Gases de Exaustão \\
\hline $\mathrm{K}$ & Argila; Filito; Taguá; Talco; Feldspato & Partículas em Suspensão \\
\hline $\mathrm{L}$ & $\begin{array}{c}\text { Energia; Óleo; Massa Cerâmica } \\
\text { Atomizada }\end{array}$ & Peças Cerâmicas; Partículas em Suspensão \\
\hline $\mathbf{M}$ & Gás natural; Energia; Peças Cerâmicas & Gases de Exaustão \\
\hline $\mathbf{N}$ & Água; Esmalte; Corantes; Fritas; Óleo & Efluente Líquido; Sedimentos \\
\hline $\mathrm{O}$ & Gás Natural; Energia; Peças Cerâmicas & Gases de Exaustão \\
\hline $\mathbf{P}$ & Peças Decoradas & Peças Cerâmicas Quebradas \\
\hline
\end{tabular}

Os resíduos industriais são obtidos em função das etapas do processamento no qual são gerados, da tecnologia utilizada e dos produtos fabricados. Assim, os principais resíduos obtidos na indústria de placas cerâmicas são:

- Lamas, provenientes do tratamento das águas de barbotina, operações de limpeza e preparação de esmaltes;

- Restos de matérias-primas, aditivos e peças cruas (resíduos crus);

- Resíduos de depuração de gases;

- Produtos acabados fora de especificações (resíduos queimados).

A quantidade total de resíduos é variável, dependendo do controle de processamento, da qualidade das matérias-primas, do nível e do controle de 
qualidade dos produtos, podendo ser estimada em 1,0 a $10,0 \%$ da produção nas indústrias brasileiras.

Dos constituintes dos resíduos, as lamas, por terem origem, basicamente, na preparação de esmaltes, são consideradas como resíduos tóxicos. Os demais resíduos são considerados inertes. A tabela 02 apresenta uma composição química média da lama produzida nas indústrias de placas cerâmicas da região de Castellón, Espanha, analisada por BLASCO et al. (1992), no Instituto de Tecnologia Cerâmica.

Tabela 02: Análise química média da lama das indústrias de placas cerâmicas da região de Castellón, Espanha.

FONTE: BLASCO et al. (1992).

\begin{tabular}{|c|c|}
\hline $\mathrm{SiO}_{2}$ & $40-60 \%$ \\
\hline $\mathrm{Al}_{2} \mathrm{O}_{3}$ & $5-15$ \\
\hline $\mathrm{B}_{2} \mathrm{O}_{3}$ & $0-10 \%$ \\
\hline $\mathrm{Fe}_{2} \mathrm{O}_{3}$ & $0,1-5 \%$ \\
\hline $\mathrm{CaO}$ & $5-15 \%$ \\
\hline $\mathrm{MgO}$ & $0,5-3 \%$ \\
\hline $\mathrm{Na}_{2} \mathrm{O}$ & $0.5-3 \%$ \\
\hline $\mathrm{K}_{2} \mathrm{O}$ & $0.5-3 \%$ \\
\hline $\mathrm{TiO}_{2}$ & $0-7 \%$ \\
\hline $\mathrm{ZrO}_{2}$ & $1-15 \%$ \\
\hline $\mathrm{PbO}$ & $0,1-15 \%$ \\
\hline $\mathrm{BaO}$ & $0,1-3 \%$ \\
\hline $\mathrm{ZnO}$ & $1-8 \%$ \\
\hline Perda a $1000^{\circ} \mathrm{C}$ & $1-12 \%$ \\
\hline
\end{tabular}


Dentre os métodos de gerenciamento de resíduos, não há dúvidas que a melhor prática é a redução de resíduos na fonte. Como enuncia um ditado popular: “é melhor prevenir do que remediar”, entretanto, quando não é possível a redução na fonte e os resíduos são produzidos, as técnicas de reutilização devem ser utilizadas.

A reutilização dos resíduos, bem como a redução na fonte, apresentam vantagens de ordem econômica e comercial. De ordem econômica, devido ao melhor aproveitamento da matéria-prima, redução ou eliminação de pagamentos de multas ou problemas com os órgãos ambientais, além do estudo e aumento do nível de controle do processo de produção. As vantagens comerciais são observadas na melhora da imagem da empresa, a facilidade de obtenção de certificados de qualidade ou ecológicos nos produtos e/ou processos, que podem refletir no aumento da competitividade, resultando na conquista de mercados consumidores internacionais, além de crescimento do mercado interno.

MONFORT e ENRIQUE (1997), em estudos de resíduos das indústrias de placas cerâmicas da região de Castellón, na Espanha, apresentam a possibilidade de reciclagem das lamas e resíduos crus no processo de preparação de massas e na fabricação de fritas e esmaltes, porém não apresentam estudos sobre a possibilidade da reciclagem dos resíduos queimados e destacam a necessidade de se criar vertedouros e controladores que permitam a eliminação adequada dos resíduos que não podem ser reciclados.

Em grande parte, o tratamento de resíduos fica restrito ao tratamento das águas residuárias, cuja legislação e fiscalização são mais coercivas. Como existe a falta de legislação específica e de orientação, os resíduos que não são reutilizados, são simplesmente descartados em aterros ou enviados gratuitamente para empresas de pavimentação, onde serão utilizados como brita.

A Reutilização desses resíduos é muito importante, mas é necessário fazê-la com critérios preestabelecidos, sendo imprescindível um estudo das variáveis de processo, para que não se comprometa a qualidade final dos produtos. É importante salientar que a situação atual das indústrias brasileiras é de pouca informação técnica sobre o assunto, e que grande parte dessas indústrias não recicla seus resíduos.

Quando se analisam os demais países produtores de placas cerâmicas, pode-se observar que essa preocupação com os resíduos cerâmicos é geral. Em Portugal 
ocorreram intensas mobilizações nesse sentido durante o ano de 2000 e 2001, com as atividades continuando nesse ano. Segundo um estudo que o CENTRO TECNOLÓGICO de CERÂMICA e VIDRO - CTCV (2000) desenvolveu com mais de 150 empresas cerâmicas portuguesas, o impacto ambiental mais importante da indústria cerâmica se refere ás emissões de gases com flúor (das indústrias do subsetor de cerâmica estrutural e de acabamento). As emissões de chumbo foram observadas em algumas unidades industriais que fabricam produtos vidrados. As partículas constituem um problema na maioria dos atomizadores.

Em algumas fábricas os efluentes líquidos continuam a conter níveis elevados de partículas em suspensão, devido a um inadequado uso de tratamento dos mesmos. A poluição ambiental está geralmente associada a compressores e a sistemas de ventilação e os resíduos sólidos incluem embalagens, restos de produtos, lamas, moldes velhos e lubrificantes.

Com vista a todos esses problemas, foi lançado um projeto ambiental de apoio à indústria cerâmica. O Projeto ECOVALOR (2000) atende ao setor da cerâmica, em todos os seus sub-setores (construção, utilitária e decorativa, etc.), cujas produções originam os resíduos cerâmicos. Estes resíduos, ainda que não sendo tóxicos, atingem volumes excessivos e aparecem descartados em zonas pouco adequadas. Tal projeto apresenta-se como uma iniciativa para a criação de uma estação de transferência de resíduos da indústria cerâmica portuguesa, constituindo, assim, uma tentativa de solução para uma lacuna existente em nível de sistema integrado de gestão de resíduos.

Atualmente, um dos problemas meio ambientais mais importantes ligados ao processo de fabricação de placas cerâmicas esmaltadas é a correta eliminação dos resíduos (lamas) das estações de tratamento de águas residuais industriais (ETARIs), que têm origem nas operações de limpeza e preparação de esmaltes, sendo dos resíduos o potencialmente mais tóxico. A natureza e a quantidade de resíduos das ETARIs variam muito, por isso não é possível definir características específicas, porém é possível estabelecer uma margem relativamente freqüente de variação.

Na Espanha, esses resíduos estão sendo reciclados parcialmente por incorporação à massa cerâmica do próprio processo de produção, porém existem alguns resíduos que não podem ser adicionados à massa cerâmica, que se descartam 
em aterros não controlados e sem nenhum tratamento prévio, uma vez que o setor cerâmico espanhol não dispõe de instalações capazes de eliminar adequadamente esses resíduos.

No Brasil, em especial no pólo cerâmico de Santa Gertrudes, por ser o processo produtivo via-seca, todos os resíduos provenientes das ETARIs, os resíduos crus e os resíduos originados das operações de despoeiramento são automaticamente reprocessados, misturados à massa cerâmica (nas indústrias que reciclam). No caso da Incefra, os resíduos automaticamente reciclados são os resíduos crus e partículas de despoeiramento. Os resíduos de ETARI são embalados em big bags e armazenados em galpões destinados a esse fim e os resíduos queimados são doados para pavimentação das estradas de terra da região.

Foi observado que os trabalhos científicos disponíveis referem-se, principalmente, aos resíduos das ETARIs e não mencionam, em nenhum momento, o destino dos resíduos queimados.

\subsection{ASPECTOS ECONÔMICOS DO SETOR DE PLACAS CERÂMICAS}

\subsubsection{O Mercado Mundial}

A cerâmica, em nível mundial, apresentou nos últimos 30 anos um acentuado desenvolvimento tecnológico devido, principalmente, ao avanço da tecnologia de combustão, da automação da produção e do conhecimento da ciência dos materiais.

Para VIVONA (2001), “o forte desenvolvimento da tecnologia e conseqüente incremento da produção dos materiais cerâmicos ofereceu ao mercado um produto com melhores características, mais bonito e com custos adequados ao mercado consumidor”.

De acordo com os dados do ano de 1999 fornecidos pela ANFACER Associação Nacional dos Fabricantes de Cerâmica de Revestimento, os principais produtores, em ordem decrescente, foram China, Itália, Espanha, Brasil, e Turquia, responsáveis por 3.386 milhões de $\mathrm{m}^{2}$. 
De acordo com o balanço anual do setor cerâmico fornecido pela ASCER Associación Española de Fabricantes de Azulejos, Pavimentos y Baldosas Cerámicas, a produção mundial em 2000 foi de 4.122,8 milhões de $\mathrm{m}^{2}$.

Analisando as informações constantes no referido balanço, observa-se que os países que apresentaram maiores variações na taxa de crescimento de produção são aqueles que aumentaram a produção para atender ao consumo interno, como por exemplo, a China e a Índia.

O consumo per capita é informado na figura 06, onde podemos observar, principalmente, o grande potencial de crescimento do mercado interno do Brasil e dos Estados Unidos.

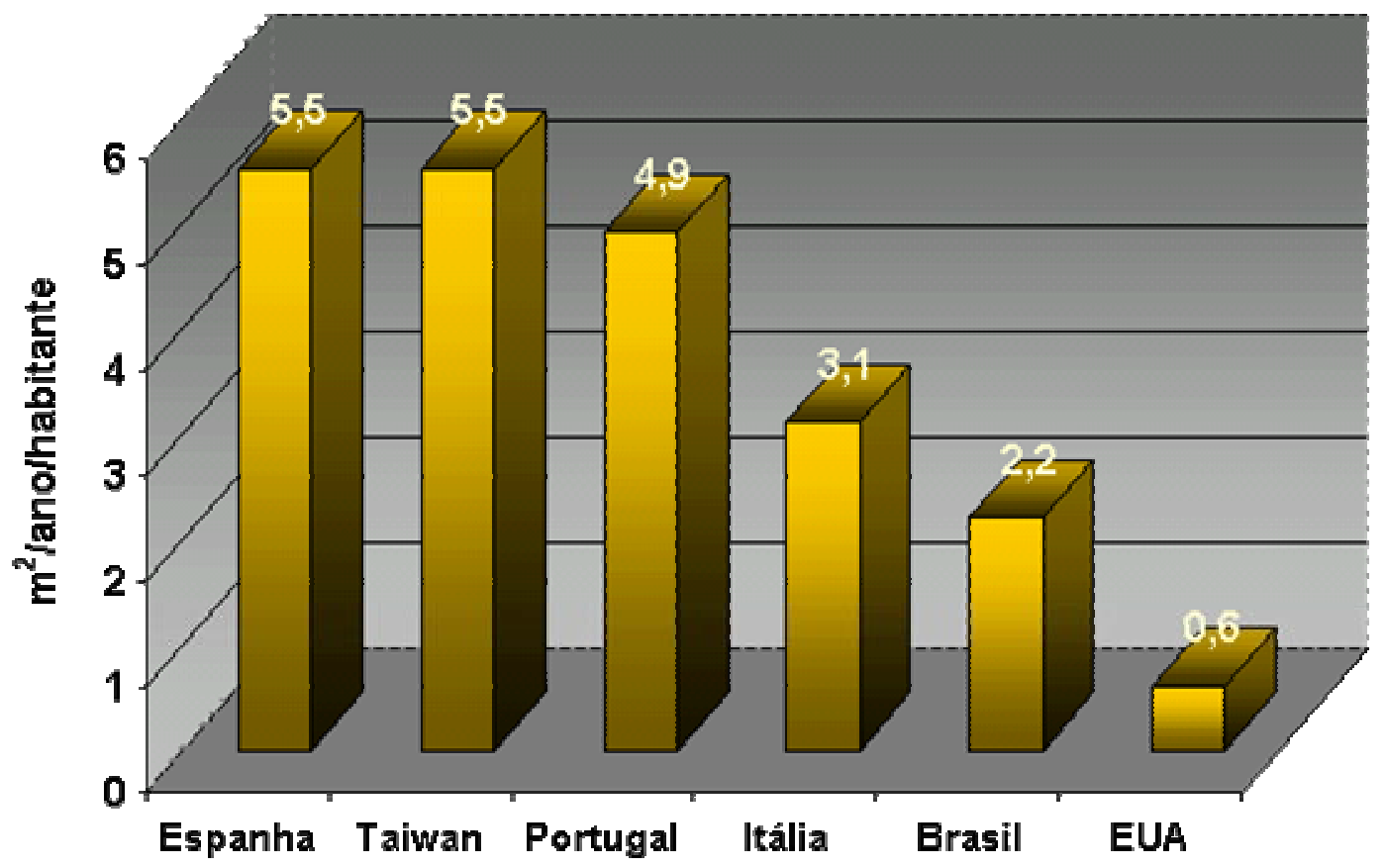

Figura 06 Consumo per capita de placas cerâmicas, em 1998.

FONTE: ANFACER (2001).

Quanto ao consumo, os principais países consumidores foram, em ordem decrescente, China, Brasil, Espanha, Estados Unidos, Alemanha e Itália. A China está se tornando evidente no mercado mundial, devido à política de abertura de mercado (uma vez que ainda está sob o regime Comunista) e a grande população que representa um importante mercado consumidor. O Brasil se tornou um importante 
país consumidor de placas cerâmicas, em grande parte devido à estabilização da economia e ao aumento do poder aquisitivo das classes de mais baixa renda, visto que estas são uma alternativa de revestimento de excelentes qualidades, com baixo custo, em relação ao demais tipos de revestimentos.

Tabela 03: Balanço mundial dos principais países economicamente ativos no setor de cerâmica de revestimento.

FONTES: ANFACER (2001) e ASCER (2001).

\begin{tabular}{|c|c|c|c|c|c|}
\hline País & $\begin{array}{c}\text { Produção } \\
(1999) \\
\left(\text { milhões } \mathrm{m}^{2}\right)\end{array}$ & $\begin{array}{c}\text { Consumo } \\
(1999) \\
\left(\text { milhões } \mathrm{m}^{2}\right)\end{array}$ & $\begin{array}{c}\text { Exportações } \\
(1999) \\
\left(\text { milhões } \mathrm{m}^{2}\right)\end{array}$ & $\begin{array}{c}\text { Importações } \\
(1999) \\
\left(\text { milhões } \mathrm{m}^{2}\right)\end{array}$ & $\begin{array}{c}\text { Consumo } \\
\text { Per capita } \\
(1999) \\
\mathrm{m}^{2} / \mathrm{hab} .\end{array}$ \\
\hline China & 1600 & 1376 & 10,5 & $\mathrm{nd}$ & $\mathrm{nd}$ \\
\hline Itália & 606 & 190,0 & 416,8 & $\mathrm{nd}$ & 3,1 \\
\hline Espanha & 602 & 272,7 & 270,2 & $\mathrm{nd}$ & 5,5 \\
\hline Brasil & 428 & 382,4 & 47,7 & $\mathrm{nd}$ & 2,2 \\
\hline Turquia & 150 & 102,9 & 48,5 & $\mathrm{nd}$ & 1,6 \\
\hline EUA & $\mathrm{nd}$ & 210,0 & 3,8 & 140,3 & 0,6 \\
\hline
\end{tabular}

nd: não determinado

Em relação às exportações, a Itália e a Espanha dominam o setor, sendo responsáveis por 67,2\% das exportações mundiais. A Itália detém 40,8\% e a Espanha detém 26,4\% da cota mundial, seguidas da Turquia e do Brasil, ambos com 4,7\% das exportações mundiais.

A participação brasileira, embora significativa, ainda é um pouco tímida em relação ao seu potencial exportador, não sendo maior devido, entre outros motivos, à excessiva carga tributária, ao chamado “custo Brasil” e ao modesto grau de certificações de produtos e processos adequados às exigências do comércio externo. Porém com a atual política econômica que dita “exportar para não morrer”, esses motivos tendem a ser minimizados, facilitando o acesso às exportações de produtos brasileiros, podendo levar à conquista de novos mercados consumidores. 
Os principais países importadores são, em ordem decrescente, a Alemanha, os Estados Unidos e a França. Os Estados Unidos são um mercado em franca expansão, tendo dobrado o volume de importações de placas cerâmicas, que era de aproximadamente 100 milhões de metros quadrados no ano de 1990, para 210 milhões de metros quadrados no ano de 1999, apresentando um consumo per capita de apenas 0,6 $\mathrm{m}^{2}$, evidenciando que as importações podem aumentar ainda mais.

Embora a Alemanha seja o mercado mais importante da Europa, o crescimento das vendas é muito limitado, devido á forte competição com outros sistemas de revestimentos, onde o fator climatológico tem expressiva influência.

\subsubsection{A Indústria Brasileira.}

A produção de placas cerâmicas está concentrada em 4 pólos industriais, distribuídos em 2 regiões do Brasil: a região sul e a sudeste. Os 4 pólos industriais compreendem o pólo de Criciúma - SC, o da grande São Paulo, o de Mogi-Guaçú e de Santa Gertrudes, no estado de São Paulo.

De acordo com a ANFACER (2002), o setor brasileiro de placas cerâmicas é formado por 131 empresas, com capacidade instalada de 536,7 milhões de $\mathrm{m}^{2}$ /ano, cuja produção em 2000 foi de 452,7 milhões de $\mathrm{m}^{2}$, representando $84 \%$ da capacidade instalada, com faturamento de 2,55 bilhões de reais. O Brasil exporta principalmente para os Estados Unidos e para os países membros do Mercosul e da América Latina.

Da produção anual, 40\% correspondem ao processo via seca, produzida praticamente no pólo de Santa Gertrudes e 60\%, ao processo via úmida.

O pólo de Santa Gertrudes é composto pelas cidades de Rio Claro, Limeira, Piracicaba, Iracemápolis, Cordeirópolis e Santa Gertrudes, abrangendo 39 empresas, com produção (1998) de aproximadamente 160 milhões de $\mathrm{m}^{2}$, cuja exportação representou 5\% da produção, gerando 5000 empregos diretos.

O que torna esse pólo tão atrativo aos investimentos é a localização privilegiada, com acesso às principais rodovias do estado, próximo ao grande 
mercado consumidor (grande São Paulo) e às universidades, além de se situar em uma região com grandes jazidas de argila de excelente qualidade, principal matériaprima das placas cerâmicas.

\subsubsection{Vale A Pena Reciclar?}

De acordo com estudos de MONFORT et al. (1992), a composição dos resíduos cerâmicos é avaliada como sendo correspondente, em peso, a 10\% em resíduos de ETARIs, 11,6\% em partículas de despoeiramento do ar, 49\% em resíduos crus e, 29,4\% em resíduos queimados, como ilustra a figura 07.

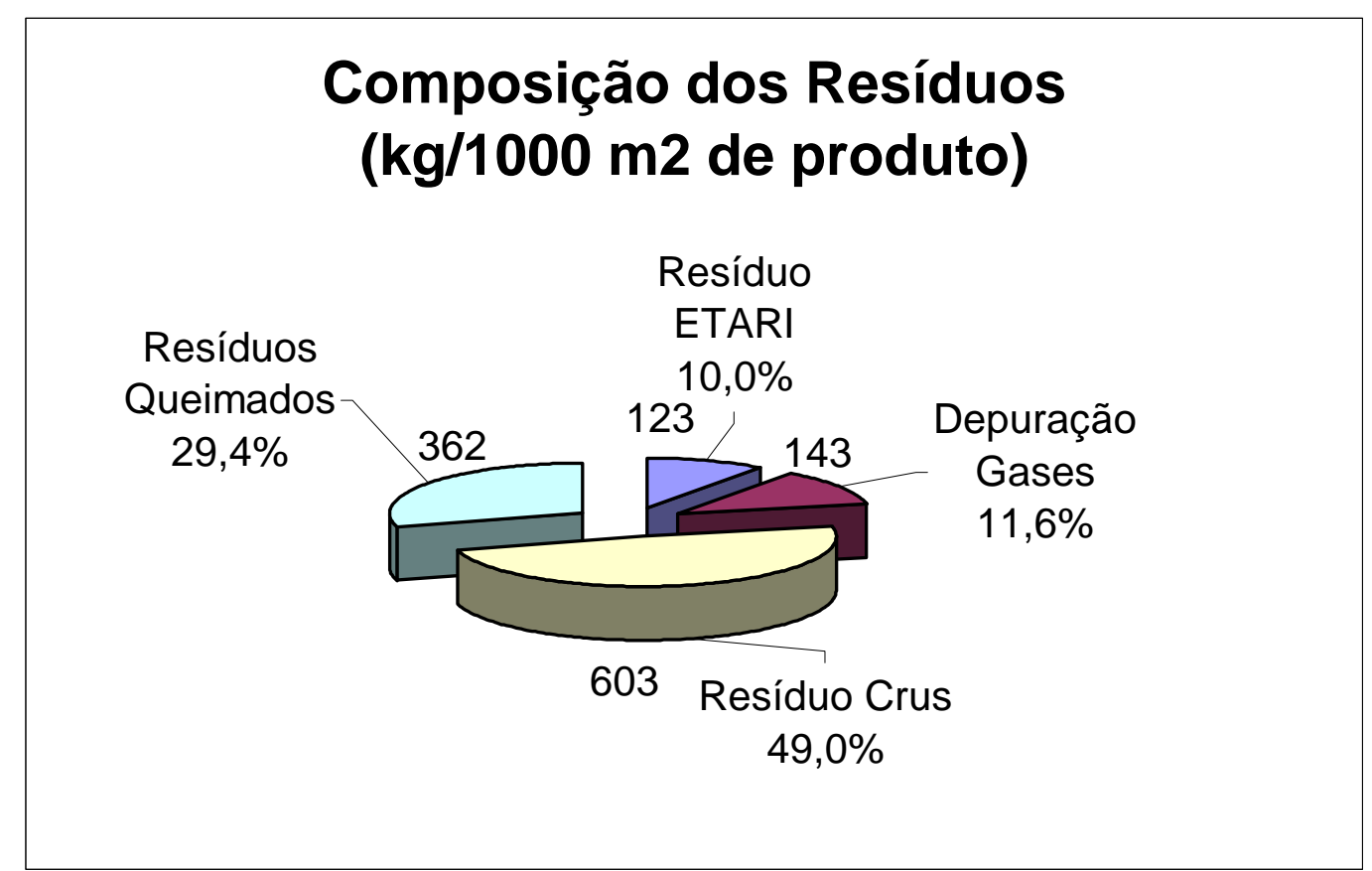

Figura 07: Composição em peso dos resíduos obtidos no processo de fabricação de placas cerâmicas.

FONTE: MONFORT et al. (1992).

Desses resíduos, os que efetivamente não são reciclados são os resíduos queimados, significando uma perda real de investimentos, os resíduos crus e da 
depuração dos gases, reciclados automaticamente e os resíduos das ETARIs reciclados por algumas indústrias, porém na condição de improviso, sem conhecimento sólido dessa prática.

A quantidade total de resíduos produzidos nos processos de fabricação de placas esmaltadas do setor de revestimentos espanhol, em 1991, foi estimada em 6\% em peso, correspondendo a $1231 \mathrm{~kg}$ de resíduos $/ 1000 \mathrm{~m}^{2}$ de placas cerâmicas. Devido à falta de informações atualizadas, foi feita uma estimativa, baseando-se nos estudos de Monfort et al., da quantidade de resíduos produzidos no mundo, como sendo de $1 \%$ em peso em todos os países; para se avaliar o quanto se perde com a produção de resíduos nas indústrias de placas cerâmicas, optou-se por adotar essa porcentagem porque significa um baixo índice de emissão de resíduos das indústrias. Evidentemente, essa quantidade, estimada de 1\% em peso, pode ser diferente, uma vez que a quantidade de resíduos produzidos depende de muitas variáveis de processo e, nem todas as indústrias no mundo estão atualizadas tecnologicamente, para produzir um mínimo de resíduos.

Assim, a quantidade de resíduos totais de 1\% em peso representaria $205 \mathrm{~kg}$ de resíduos/ $1000 \mathrm{~m}^{2}$ placas cerâmicas. Deste modo, se todas as cinco principais indústrias produtoras de placas cerâmicas do mundo produzissem essa porcentagem de resíduos totais, a quantidade em peso desses resíduos produzidos no ano de 1999 seria de 694 mil toneladas. Os resíduos queimados, que não são reaproveitados, representam, portanto, perda real de capital, seriam estimados em 204 mil toneladas. Analogamente, a produção de resíduos totais no Brasil, durante o mesmo período, seria de 87,7 mil toneladas, sendo 25,8 mil toneladas de resíduos queimados.

Através de dados da ANFACER, em 2000, a produção brasileira apresentou um faturamento da ordem de 1,3 bilhões de dólares, o que representou um faturamento de 3,4 dólares $/ \mathrm{m}^{2}$ de placas. Esse faturamento leva em consideração todos os tipos de placas cerâmicas. Assim, para uma produção de 181 milhões de metros quadrados, do pólo de Santa Gertrudes (em 2000), considerando uma perda de $1 \%$ em peso da produção como sendo os resíduos totais, temos 37 mil toneladas correspondentes à perda por resíduos totais e 10,9 mil toneladas como sendo os resíduos queimados. 
Considerando que o pólo produz, em sua maioria, placas cerâmicas para atender as populações de média e baixa renda, onde o faturamento pode ser descrito, em média, como sendo 2,5 dólares $/ \mathrm{m}^{2}$, a perda seria de 1,82 milhões de dólares anuais, o que, aproximadamente, representaria $0,14 \%$ do faturamento anual.

Segundo relatório interno da Incefra, as quantidades e os tipos de resíduos produzidas na indústria, em Cordeirópolis, são apresentadas na tabela 04.

Tabela 04: Produção de Resíduos na Incefra em 2001.

FONTE: Relatório interno da Incefra (2001)

\begin{tabular}{|c|c|}
\hline Resíduo & Quantidade (ton/mês) \\
\hline Lama ETARI & 30,0 \\
\hline Resíduo Cru & 20,0 \\
\hline Resíduo Queimado & 150,0 \\
\hline Partícula Despoeiramento & 8,0 \\
\hline
\end{tabular}

Ao contrário da avaliação de MONFORT et al. (1992), sobre a composição dos resíduos cerâmicos na Espanha, a Incefra apresenta o resíduo queimado como sendo o majoritário na composição dos resíduos totais, o que é desfavorável do ponto de vista econômico, porque esses resíduos representam uma perda de matériasprimas, energia (conformação, secagem e queima) e horas de trabalho, perda essa que é efetiva, porque esses resíduos não são reciclados, como os demais resíduos, além de evidenciar problemas no processo produtivo da empresa. A figura 08 apresenta a composição dos resíduos produzidos na Incefra durante o ano de 2001.

O catálogo de produtos da empresa apresenta um valor médio de massa das placas cerâmicas, como sendo $15 \mathrm{~kg} / \mathrm{m}^{2}$. A Incefra tem uma produção declarada de $1.300 .000 \mathrm{~m}^{2} /$ mês (em 2001), o que corresponde a uma produção total de 19500 toneladas de placas cerâmicas/mês. A quantidade produzida de resíduos totais é de 208 toneladas/mês, significando 1,067\% da produção mensal. Os resíduos queimados representam 72,12\% em peso dos resíduos totais, assim, a quantidade produzida desses resíduos é de 0,77\% em peso da produção mensal de placas cerâmicas, 
correspondendo a uma perda real de $10.000 \mathrm{~m}^{2}$. Assumindo um faturamento de 2,0 dólares/m² , essa perda seria de 20.000 dólares/mês ou 240.000 dólares/ano.

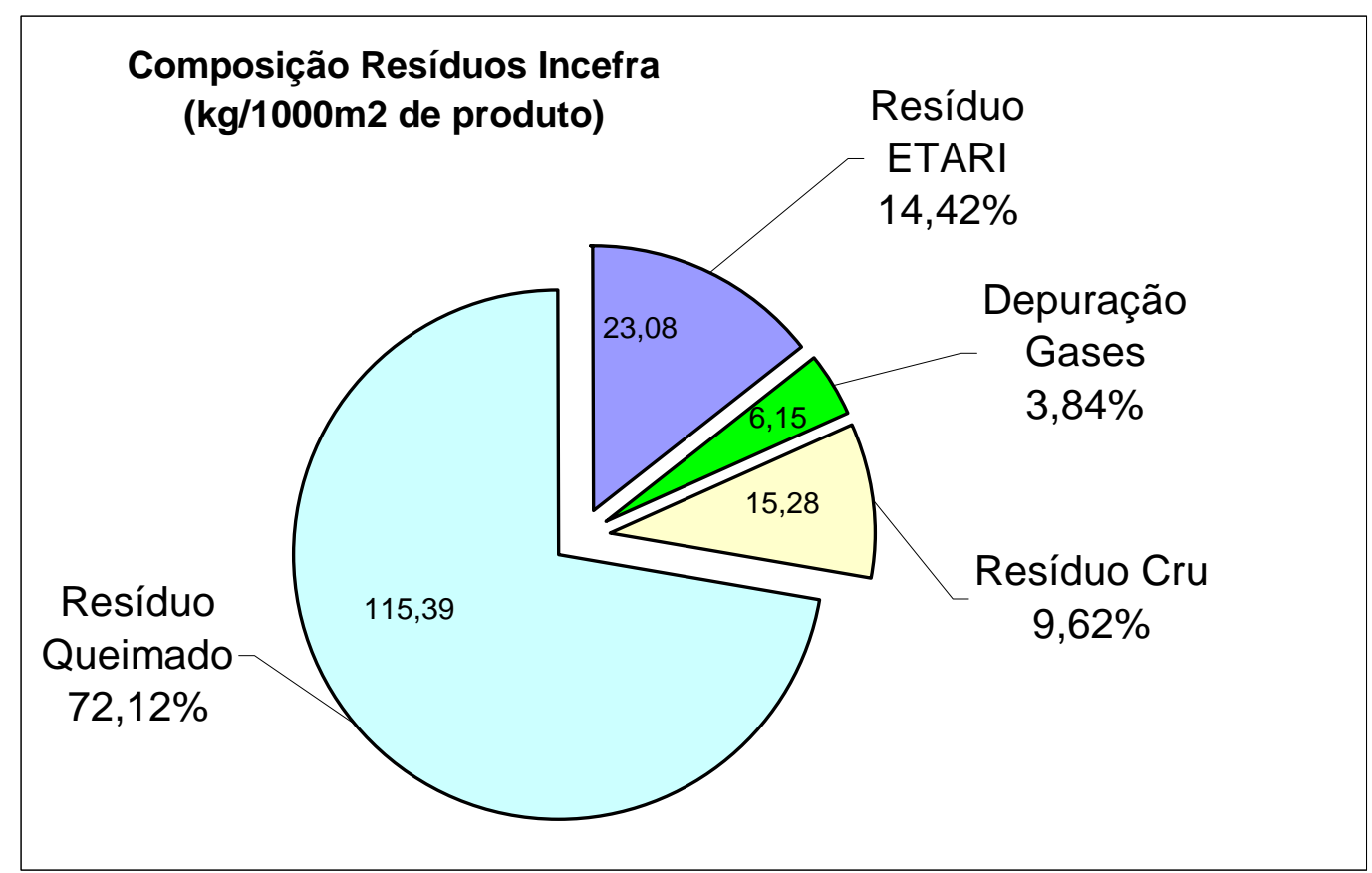

Figura 08: Composição em peso dos resíduos obtidos no processo de fabricação de placas cerâmicas da Incefra, em 2001

FONTE: Relatório interno da Incefra (2001).

Com projeções que consideram níveis aceitáveis de produção de resíduos nas indústrias de placas cerâmicas, observa-se que as perdas na produção ocasionando os resíduos são significativas e apenas serão efetivas se não houver um reprocessamento desses materiais considerados resíduos. A questão é que a produção desses resíduos se assemelha ao vazamento de uma torneira por gotejamento; parece pequeno, mas consome muita água, ocasionando uma perda considerável e uma conta elevada para ser paga. Desta forma, muitas indústrias não se interessam pela reciclagem dos resíduos queimados, e realizam a reciclagem dos demais resíduos com poucos critérios.

As estimativas acima, os problemas ambientais e os resultados das pesquisas com a reciclagem, no item de resultados e discussões, demonstram a importância de 
se reciclar esses resíduos, ficando claro que não é bom perder capital, principalmente em um mundo com economia globalizada e altamente competitiva.

Deve-se realizar a reciclagem sempre que houver resíduo em quantidade mínima para ser adicionado à massa cerâmica após avaliação da quantidade mais adequada a ser adicionada, tendo em vista os efeitos da adição dos resíduos sobre as propriedades mecânicas das placas cerâmicas.

A estimativa de perda de capital através dos resíduos, realizada para a Incefra, demonstra que, apesar do controle de qualidade da produção, do processo automatizado, mesmo um índice de produção de resíduos de $1 \%$ da produção, que se considera um baixo índice de emissão de resíduos, pode-se tornar muito significativo, dependendo do volume de produção da empresa.

\subsection{A LEGISLAÇÃO SOBRE RESÍDUOS INDUSTRIAIS, APLICADA À INDÚSTRIA CERÂMICA.}

Um dos problemas que mais preocupam a indústria em geral e a indústria cerâmica em particular, é a adoção de medidas necessárias para cumprir as distintas legislações em vigor no que tange ao meio ambiente.

MONFORT e JOSÉ (1998) realizaram um trabalho que consistiu em uma revisão da legislação sobre o meio ambiente no tocante aos resíduos industriais, com especial atenção aos tóxicos e perigosos. Compararam-se distintas definições de resíduos tóxicos e perigosos e os critérios para avaliar a toxicidade de um determinado resíduo nas normas em vigor nos Estados Unidos, Comunidade Européia, Itália, Espanha e Brasil. Foram escolhidas estas legislações por diferentes motivos, a dos Estados Unidos porque é a legislação mais avançada em nível mundial, a da Itália e Espanha por serem os principais países produtores de placas cerâmicas do mundo e a da Comunidade Européia, por ser o ponto de referência obrigatória, por Espanha ser um país membro. A tabela 05 apresenta as principais características dos procedimentos normalizados para o desenvolvimento dos ensaios de lixiviação nos Estados Unidos, Comunidade Européia e Brasil. 
Tabela 05: Principais características dos procedimentos normalizados para os ensaios de lixiviação nos Estados Unidos, Comunidade Européia e Brasil.

FONTE: BLASCO et al (1992).

\begin{tabular}{|c|c|c|c|c|}
\hline País & $\overline{U S}$ & & CEE & Brasil \\
\hline Procedimento & Método EP & Método TCLP & \begin{tabular}{|l} 
Baseado \\
DIN38414-54
\end{tabular} & \begin{tabular}{|l|} 
Baseado \\
ABNT 01.043 \\
\end{tabular} \\
\hline $\begin{array}{l}\text { Referência } \\
\text { Legal }\end{array}$ & $\begin{array}{l}\text { Registro } \\
\text { Federal } \\
19 \text { Maio } 1980\end{array}$ & \begin{tabular}{|l} 
Registro \\
Federal \\
07 Nov. 1989 \\
\end{tabular} & $\begin{array}{l}\text { Proposta } \\
\text { Diretiva } \\
\text { 91/C190/01 }\end{array}$ & $\begin{array}{l}\text { NBR } 10.005 \\
\text { Set/1987 }\end{array}$ \\
\hline $\begin{array}{l}\text { Meio de } \\
\text { Extração }\end{array}$ & $\begin{array}{l}\text { Água destilada } \\
\text { se pH>5 ácido } \\
\text { acético } 0,5 \mathrm{~N} \\
\text { (máx. } 4 \mathrm{~mL} / \mathrm{gr} \text { ) }\end{array}$ & $\begin{array}{l}\text { Água destilada } \\
\text { Adição em } \\
\mathrm{f}(\mathrm{pH}) \\
\mathrm{Hac} / \mathrm{NaOH} \text { ou } \\
\mathrm{HAC} \\
\end{array}$ & Água destilada & $\begin{array}{l}\text { Água destilada se } \\
\text { pH>5 ácido acético } \\
0,5 \mathrm{~N} \\
\text { (máx. } 4 \mathrm{~mL} / \mathrm{gr} \text { ) }\end{array}$ \\
\hline $\begin{array}{l}\text { Tempo de } \\
\text { extração }\end{array}$ & 24 horas & 18 horas & 24 horas & 24 horas \\
\hline pH de Extração & $5,0 \pm 0,2$ & Não especifica & Não especifica & $5,0 \pm 0,2$ \\
\hline Temperatura & $20-40^{\circ} \mathrm{C}$ & $22 \pm 3^{\circ} \mathrm{C}$ & ambiente & ambiente \\
\hline $\begin{array}{l}\text { Agitação } \\
\text { (rpm) }\end{array}$ & Não especifica & $30 \pm 2$ & 0,5 & Não especifica \\
\hline $\begin{array}{l}\text { Dimensão do } \\
\text { reator }\end{array}$ & Não especifica & \begin{tabular}{|l} 
Modelos \\
autorizados
\end{tabular} & \begin{tabular}{|l|} 
Frasco vidro \\
$2000 \mathrm{~mL}$
\end{tabular} & Não especifica \\
\hline $\begin{array}{l}\text { Água }+ \\
\text { Lixiviado/ } \\
\text { Resíduo } \\
\end{array}$ & 20 & 20 & 10 & 20 \\
\hline $\begin{array}{l}\text { Resíduos } \\
\text { Monolíticos }\end{array}$ & $\begin{array}{l}\text { Proveta } \\
\text { Cilíndrica } \\
3,3 \mathrm{~cm} \mathrm{x} \mathrm{7,1} \mathrm{cm}\end{array}$ & Não especifica & Não especifica & $\begin{array}{l}\text { Compactação } \\
\text { prévia de acordo } \\
\text { com procedimento } \\
\text { da norma }\end{array}$ \\
\hline $\begin{array}{l}\text { Tamanho de } \\
\text { partícula }\end{array}$ & $\begin{array}{l}<9,5 \mathrm{~mm} \\
\text { ou } 3,1 \mathrm{~cm}^{2} / \mathrm{g}\end{array}$ & $\begin{array}{l}<9,5 \mathrm{~mm} \\
\text { ou } 3,1 \mathrm{~cm}^{2} / \mathrm{g}\end{array}$ & $<10 \mathrm{~mm}$ & $\begin{array}{l}<9,5 \mathrm{~mm} \\
\text { ou } 3,1 \mathrm{~cm}^{2} / \mathrm{g}\end{array}$ \\
\hline $\begin{array}{l}\text { Avaliação da } \\
\text { Toxicidade }\end{array}$ & $\begin{array}{l}\text { Análise } \\
\text { Química }\end{array}$ & $\begin{array}{l}\text { Análise } \\
\text { Química }\end{array}$ & $\begin{array}{l}\text { Análise } \\
\text { Química }\end{array}$ & Análise Química \\
\hline
\end{tabular}

No presente trabalho, foram adicionadas a esta revisão das legislações meio ambientais do mundo as considerações sobre as normas brasileiras.

Ao se analisar as diferentes normas mundiais, é observado que a problemática da existência de diferentes legislações é baseada, fundamentalmente, no modo de descarte e tratamento, bem como os índices permitidos de determinada substância para classificá-la como tóxica e perigosa. 
Para a classificação de um resíduo se utilizam numerosos critérios tais como toxicidade, nocividade e outras, que, à medida que avança a ciência, requerem sucessivas revisões. A característica de toxicidade se estabeleceu a partir de 1980 com base em um ensaio de extração (método de lixiviação), no qual a concentração de alguns elementos dos lixiviados que se obtêm deve estar abaixo dos limites estabelecidos para que o resíduo não seja qualificado como resíduo tóxico perigoso (RTP). A tabela 06 apresenta um resumo dos critérios regulamentados para avaliar a toxicidade de um resíduo, em função das características do lixiviado obtido.

Tabela 06: Regulamentação das características do lixiviado.

FONTE: BLASCO et al. (1992), modificado.

\begin{tabular}{|c|c|c|c|c|c|}
\hline País & USA & CEE & Itália & Espanha & Brasil \\
\hline $\begin{array}{l}\text { Tipo de } \\
\text { ensaio }\end{array}$ & $\begin{array}{l}\text { Análise } \\
\text { Química }\end{array}$ & Análises 17D & $\begin{array}{l}\text { Análise } \\
\text { Química }\end{array}$ & Bioensaio & $\begin{array}{l}\text { Análise } \\
\text { Química }\end{array}$ \\
\hline $\begin{array}{l}\text { Limites de } \\
\text { algumas } \\
\text { espécies } \\
\text { causadoras } \\
\text { de } \\
\text { toxicidade }\end{array}$ & $\begin{array}{c}\mathrm{As}<5,0 \mathrm{ppm} \\
\mathrm{Ba}<100 \mathrm{ppm} \\
\mathrm{Cd}<1,0 \mathrm{ppm} \\
\mathrm{Cr}<5,0 \mathrm{ppm} \\
\mathrm{Pb}<5 \text {,0ppm } \\
\mathrm{Se}<1,0 \mathrm{ppm} \\
\mathrm{Ag}<5,0 \mathrm{ppm} \\
\\
\text { Lista de } \\
\text { pesticidas e } \\
\text { compostos } \\
\text { orgânicos }\end{array}$ & 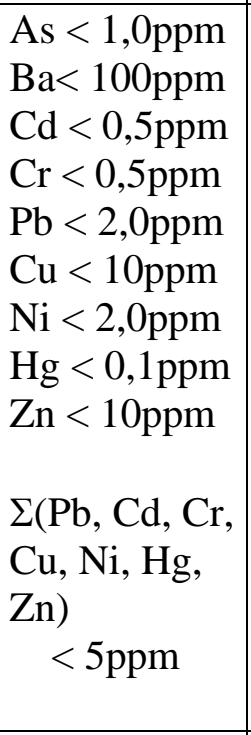 & $\begin{array}{l}\text { As }<0,5 \mathrm{ppm} \\
\mathrm{Hg}<0,005 \mathrm{ppm} \\
\mathrm{Cd}<0,02 \mathrm{ppm} \\
\mathrm{Cr}(\mathrm{VI}) \\
<0,5 \mathrm{ppm} \\
\mathrm{Pb}<0,2 \mathrm{ppm} \\
\mathrm{Cu}<0,1 \mathrm{ppm}\end{array}$ & $\begin{array}{c}\text { Bioensaio } \\
\text { Luminescência } \\
\text { Photobacterium } \\
\text { Phosphoreum } \\
\text { EC }_{50}(15 \mathrm{~min}, \\
\left.15^{\circ} \mathrm{C}\right) \\
\leq 3000 \mathrm{mg} / \mathrm{l} \\
\\
\\
\text { Bioensaio } \\
\text { inibição } \\
\text { toxicidade aguda } \\
\text { Daphnia } \\
\text { EC }_{50} \leq 750 \mathrm{mg} / \mathrm{l}\end{array}$ & $\begin{array}{l}\mathrm{As}<5,0 \mathrm{ppm} \\
\mathrm{Ba}<100 \mathrm{ppm} \\
\mathrm{Cd}<0,5 \mathrm{ppm} \\
\mathrm{Cr}<5,0 \mathrm{ppm} \\
\mathrm{Pb}<5,0 \mathrm{ppm}\end{array}$ \\
\hline $\begin{array}{l}\text { Finalidade } \\
\text { legal }\end{array}$ & $\begin{array}{l}\text { Caracterizar } \\
\text { resíduos } \\
\text { tóxicos e } \\
\text { perigosos } \\
\end{array}$ & $\begin{array}{l}\text { Definir o } \\
\text { tipo de } \\
\text { vertedouro }\end{array}$ & $\begin{array}{l}\text { Definir o tipo } \\
\text { de vertedouro }\end{array}$ & $\begin{array}{l}\text { Caracterizar } \\
\text { resíduos tóxicos } \\
\text { e perigosos }\end{array}$ & $\begin{array}{l}\text { Caracterizar } \\
\text { resíduos } \\
\text { tóxicos e } \\
\text { perigosos } \\
\end{array}$ \\
\hline
\end{tabular}

Todas as normas aqui analisadas estabelecem que, para a classificação de um resíduo como RTP, é necessário que uma ou mais espécie constante nas listas anexas às normas em questão estejam em concentrações acima dos valores permitidos. 
Como exemplo, nas normas em vigor na Itália a concentração máxima permitida para um resíduo contendo chumbo e/ou seus compostos é de 5000mg/kg na massa bruta; acima desse valor esse resíduo é considerado RTP. No Brasil, a concentração máxima permitida pelas normas é de $1000 \mathrm{mg} / \mathrm{kg}$, ou seja, um resíduo que na Itália não é considerado tóxico pode ser considerado tóxico pelas normas brasileiras. Dessa forma, se estabelece uma grande confusão devido à questão das exportações de produtos, pois fica difícil para o produtor determinar sobre qual legislação ele deve produzir seus bens. Na realidade, essa problemática se expande a todos os demais bens de consumo sujeitos ao trânsito mundial, uma vez que um determinado produto é produzido em um país, mas, após o uso, ele será descartado em outro país. O problema fica ainda mais complexo ao lembrarmos de que, ao produzirmos um resíduo, ele nos pertence mesmo depois que o enviamos para tratamento ou disposição, e, portanto, somos responsáveis pela ação desses resíduos, quando não destinado adequadamente.

Estas legislações para caracterizar os resíduos e definir o tipo de vertedouro ao qual devem ser descartados utilizam ensaios de caracterização e critérios de avaliação da toxicidade diferentes, de modo que os resultados obtidos não são comparáveis, evidenciando, assim, a necessidade da determinação de uma legislação única aplicável a todos os países.

\subsection{AS PLACAS CERÂMICAS}

As placas cerâmicas são produtos obtidos a partir de argilas e outros materiais inorgânicos quando misturados, prensados em forma de placas e posteriormente queimados. São usadas para revestir pisos e paredes.

Independentemente do sistema utilizado para a produção, a fabricação de qualquer produto cerâmico inicia-se a partir de uma mistura de matérias primas, denominada massa cerâmica, a qual sofre diversas transformações físico-químicas até alcançar as propriedades desejadas do produto acabado. 
Atualmente, a produção de placas cerâmicas se caracteriza por ampla diversidade de formas (quadrados, retângulos ou ortogonais) e tamanhos (variações entre 10x10cm até 60x60cm), bem como suas características técnicas (absorção de água, resistência mecânica, resistência abrasão do vidrado, etc). Devido a esses fatores, foi assumida, pelos órgãos competentes, uma classificação das placas cerâmicas quanto às suas propriedades físico-químicas, para que os profissionais da construção civil pudessem especificar o tipo de placa adequado ao tipo de solicitação do ambiente a recebê-la.

A classificação básica é feita pela porcentagem de absorção de água e resistência mecânica (módulo de resistência à flexão e carga de resistência de ruptura). Essas duas propriedades são as mais assumidas, uma vez que as demais podem ser estimadas a partir de análise do comportamento dessas propriedades básicas da placa cerâmica. A tabela 07 apresenta a classificação das placas cerâmicas obtidas por prensagem.

Tabela 07: Classificação das placas cerâmicas.

FONTE: Catálogo do CCB (1999) - modificado.

\begin{tabular}{|c|c|c|c|}
\hline Absorção de água & $\begin{array}{c}\text { ISO DIS } \\
13006\end{array}$ & $\begin{array}{c}\text { Absorção de água } \\
(\%)\end{array}$ & $\begin{array}{c}\text { Módulo de } \\
\text { resistência }\left(\mathrm{kgf} / \mathrm{cm}^{2}\right)\end{array}$ \\
\hline Porcelanato & BIa & 0 a $0,5 \%$ & $350-500$ \\
\hline Grés & BIb & 0,5 a $3 \%$ & $300-450$ \\
\hline Semi-Grés & BIIa & 3 a $6 \%$ & $320-350$ \\
\hline Semi-Poroso & BIIb & 6 a $10 \%$ & $180-300$ \\
\hline Poroso & BIII & 10 a $20 \%$ & $150-200$ \\
\hline
\end{tabular}

As propriedades dos produtos cerâmicos são fundamentalmente determinadas pelas matérias-primas e pela microestrutura final, que é resultado das etapas do processamento e da natureza química da massa. Desta forma, para se controlar as propriedades finais dos produtos, deve-se entender e controlar as propriedades básicas dos materiais, bem como os processos utilizados na sua produção. 
O processo de fabricação de placas cerâmicas esmaltadas consiste em cinco etapas fundamentais:

1- Preparação da massa cerâmica (via úmida ou seca);

2- Conformação da placa (predominantemente por prensagem);

3- Secagem controlada;

4- Esmaltação;

5- Queima (monoqueima ou biqueima).

\subsubsection{O Processo De Produção Das Placas Cerâmicas}

\subsubsection{A preparação da Massa cerâmica}

As matérias-primas cerâmicas são compostas basicamente de argilominerais, em seu estado natural ou com tratamento prévio, sendo classificadas, de acordo com seu comportamento em presença de água, em plásticas e não plásticas.

A composição da massa é feita baseada nas propriedades finais do produto desejado e no tipo de processamento cerâmico. Normalmente, uma massa típica para a fabricação de um produto cerâmico deve ter certos requisitos como:

a) a peça a verde deve apresentar resistência mecânica suficiente para que se dêem, com êxito, as outras etapas do processamento. Para isso, deve existir um balanço entre os materiais plásticos (argilominerais) e os materiais não plásticos (quartzo, feldspato, chamote, etc), para que a peça possa ser conformada;

b) se o processo de preparação for via úmida, a mistura deve ser facilmente defloculável;

c) a massa cerâmica deve ter uma composição química e mineralógica de maneira a permitir que as transformações físico-químicas durante o processo de queima sejam suficientes para conferir ao produto acabado as propriedades desejadas (coeficiente de dilatação, resistência mecânica, porosidade, etc).

\subsubsection{Conformação da placa cerâmica}


A conformação das placas pode ser realizada mediante processo de prensagem ou extrusão, sendo esse último muito pouco utilizado atualmente. Utilizase o processo de prensagem na maioria das indústrias de placas cerâmicas, pois proporciona maior estabilidade dimensional ao produto final.

A prensagem uniaxial pode ser efetuada com pós relativamente secos $(0-4 \%$ umidade) e pós úmidos ( 10 - 15\% umidade). Dependendo da umidade do material, a prensagem pode ser designada como prensagem a úmido ou a seco.

A compactação ocorre, inicialmente, pela quebra dos grânulos e pela redistribuição mecânica das partículas. A presença de substâncias lubrificante e ligante usualmente ajuda na redistribuição das partículas, promove a coesão entre as mesmas e facilita o destacamento da peça conformada do molde.

Altas pressões são necessárias pela prensagem a seco para que se efetue a quebra dos grânulos e a compactação se torne uniforme, por isso a prensagem a úmido é mais utilizada.

\subsubsection{Secagem}

A operação de secagem das peças cerâmicas é considerada uma operação delicada e muito importante no processo de produção. A secagem da placa cerâmica ocorre, basicamente, por dois mecanismos. Primeiro ocorre a saída das moléculas de água dos poros da peça, por capilaridade, mediante o arraste das moléculas de água da superfície, pelo ar. Esse processo ocorre até a evaporação total da água de hidratação contida nos poros. A partir desse instante, passa a ocorrer o segundo mecanismo, que é o da retirada da água adsorvida. Esse processo é mais lento e difícil.

Quando a água de hidratação é retirada, por evaporação, as partículas das matérias-primas tendem a acomodar-se nos lugares antes ocupados pelas moléculas de água, promovendo uma contração do volume da placa. Essa contração ocorre, mais expressivamente, durante o primeiro mecanismo de secagem, sendo muito pequena durante o segundo mecanismo. Devido a essa contração, a secagem da placa durante o primeiro estágio, deve ser muito bem controlada, para que não ocorram tensões, que poderão causar trincas que inutilizarão as placas. 
Pode-se avaliar a evolução da contração linear de secagem com a perda de água através das curvas de Bigot (Figura 09). Essas curvas são muito úteis para se estabelecer ciclos de secagem adequados, pela determinação do ponto crítico em que a contração linear da placa é máxima.

Os principais fatores que influenciam a secagem da placa cerâmica são:

a) a temperatura e umidade do ar;

b) a velocidade e direção do ar em contato com a placa cerâmica a ser secada;

c) a distribuição e tamanho de partículas da massa cerâmica;

d) a composição mineralógica da massa cerâmica.

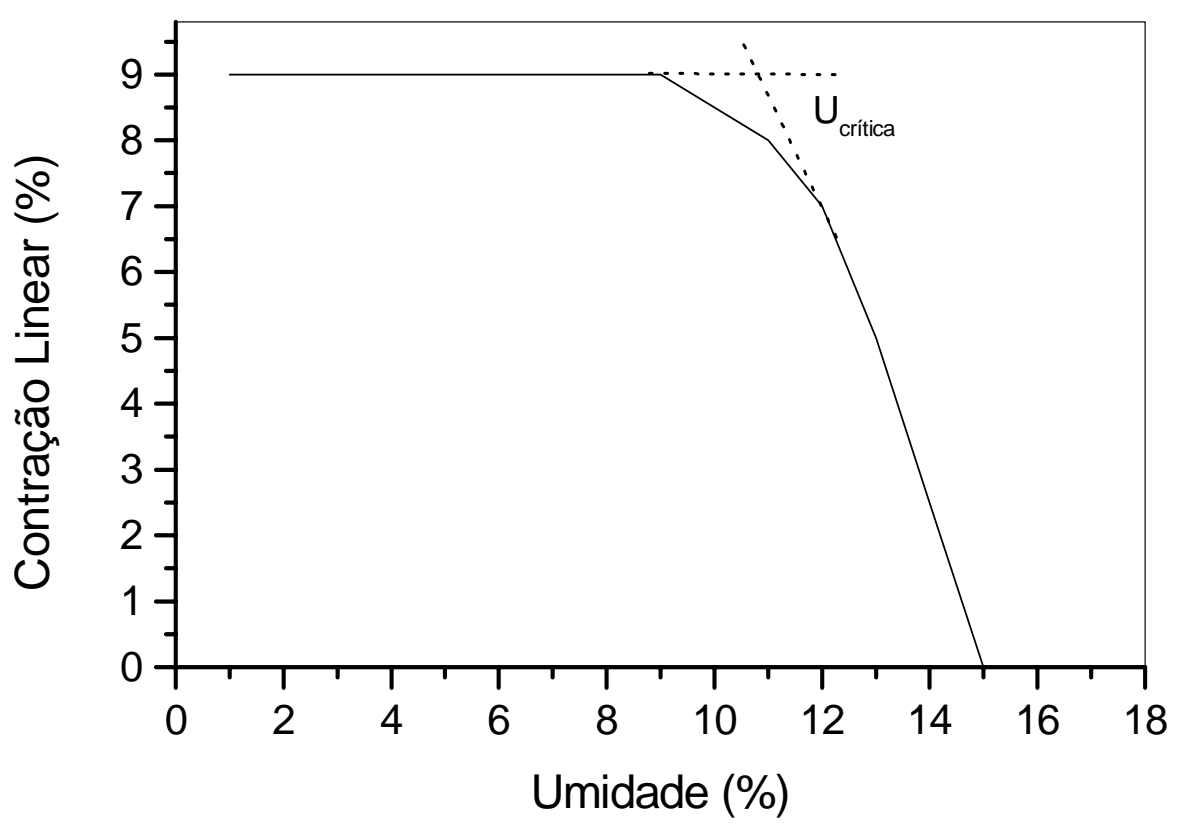

Figura 09: Curva de Bigot

FONTE: BARBA et al. (1997).

A distribuição e tamanho de partículas da massa cerâmica influenciam o processo de secagem devido ao efeito que exerce sobre a compacidade do material. Em geral, a velocidade de secagem aumenta com o tamanho médio de partícula, porque a presença de porosidade é maior, o que facilita a eliminação da umidade. A composição mineralógica influencia o processo de secagem, uma vez que cada 
composição apresenta tamanho de partículas e capacidade de adsorção de água característica.

Assim, é possível controlar determinadas patologias através do controle do processo de secagem. Um exemplo é o surgimento de eflorescência, que ocorre devido à deposição dos sais solúveis sobre a superfície da peça, o que faz com que a solubilidade dos sais aumente com o aumento da temperatura, e, deste modo, os sais sejam solubilizados e carregados até a superfície, pela água contida nos poros, por capilaridade.

\subsubsection{4- Esmaltação}

A esmaltação consiste na aplicação de uma ou mais camadas de uma suspensão conhecida como vidrado que, após a queima da placa, se torna um revestimento vítreo impermeável sobre toda a superfície superior da placa. Essa suspensão é composta por matérias-primas inorgânicas, contendo sílica, formadora de fase vítrea e óxidos de metais com funções diferentes, responsáveis, principalmente, pela coloração, opacificação, fundência, entre outras.

A esmaltação pode ser realizada por vários métodos, sendo os mais utilizados o método de cascata e campânula, para superfícies lisas e o método de serigrafia, para superfícies decoradas. Por sua natureza química, o vidrado é um elemento muito versátil, sendo projetado para se desenvolver mediante as características desejadas aos produtos finais.

\subsubsection{5- Queima}

A etapa de queima das placas cerâmicas é realizada mediante as características do produto desejável. Quando se deseja obter placas cerâmicas esmaltadas, pode-se ter o processo de monoqueima, em que a queima do suporte e do vidrado ocorre simultaneamente, ou o processo de biqueima, onde primeiro se realiza uma queima do suporte da placa e, em seguida, a placa é esmaltada e passa por uma segunda queima, para atingir as características desejadas. As principais 
características necessárias para que uma placa cerâmica possa desempenhar suas funções são:

a) boa resistência á abrasão - resistência ao desgaste superficial (depende do local a ser colocada, sendo dividida em 5 classes, de acordo com o nível de solicitação) medido pelo PEI;

b) baixa dilatação térmica e expansão por umidade, caso contrário, quando exposta a temperaturas elevadas ou locais com elevada umidade, a placa cerâmica pode apresentar patologias como eflorescências, destacamento, etc;

c) resistência a manchas, porque precisam ser facilmente limpas;

d) resistência ao ataque químico, uma vez que os produtos químicos de limpeza podem atacar a placa cerâmica, danificando-a;

e) absorção de água adequada ao local de uso associado a resistência mecânica;

f) resistência mecânica adequada à solicitação (deve ser maior em garagens e locais de grande tráfego);

g) características geométricas - devem ter alta ortogonalidade e retitude, sem apresentar empeno ou curvaturas, que dificultam o assentamento da placa, o que representa problemas ao usuário.

A queima da placa cerâmica pode ser acompanhada através das curvas de gresificação que relacionam propriedades como contração linear de queimado, absorção de água e módulo de resistência à flexão, permitindo a previsão das características da placa, podendo-se otimizar o tempo e a temperatura do processo de queima, para atender as especificações desejadas. As curvas de gresificação apresentam variações de absorção de água, retração linear e módulo de ruptura á flexão, em relação á temperatura de queima. O ponto de gresificação corresponde à interseção entre as curvas de retração linear e absorção de água, indicando a temperatura em que a placa cerâmica começa a densificar. De modo análogo, no ponto de interseção entre as curvas de módulo de ruptura à flexão e absorção de água, pode-se obter o valor da resistência mecânica no início do processo de densificação (Figura 10).

Durante a queima, as matérias-primas passam por transformações físicoquímicas, até obter as propriedades finais da placa queimada. De modo geral, 
observa-se o início destas transformações ao redor de $350^{\circ} \mathrm{C}$, quando se inicia a decomposição de carbonatos e hidróxidos e a eliminação de água de coordenação que pode se estender até aproximadamente $650^{\circ} \mathrm{C}$ (na caulinita). Nesse intervalo de temperatura ocorre a decomposição de sulfatos e oxidação da matéria orgânica presente.

Particularmente em temperaturas próximas a $573^{\circ} \mathrm{C}$ ocorre a transição da forma cristalina $\alpha$ do quartzo para a forma $\beta$, fenômeno este reversível, sendo necessária a atenção durante este intervalo, para que esse processo não produza fissurações, uma vez que a dilatação/contração experimentada durante a transição de fases é considerável.

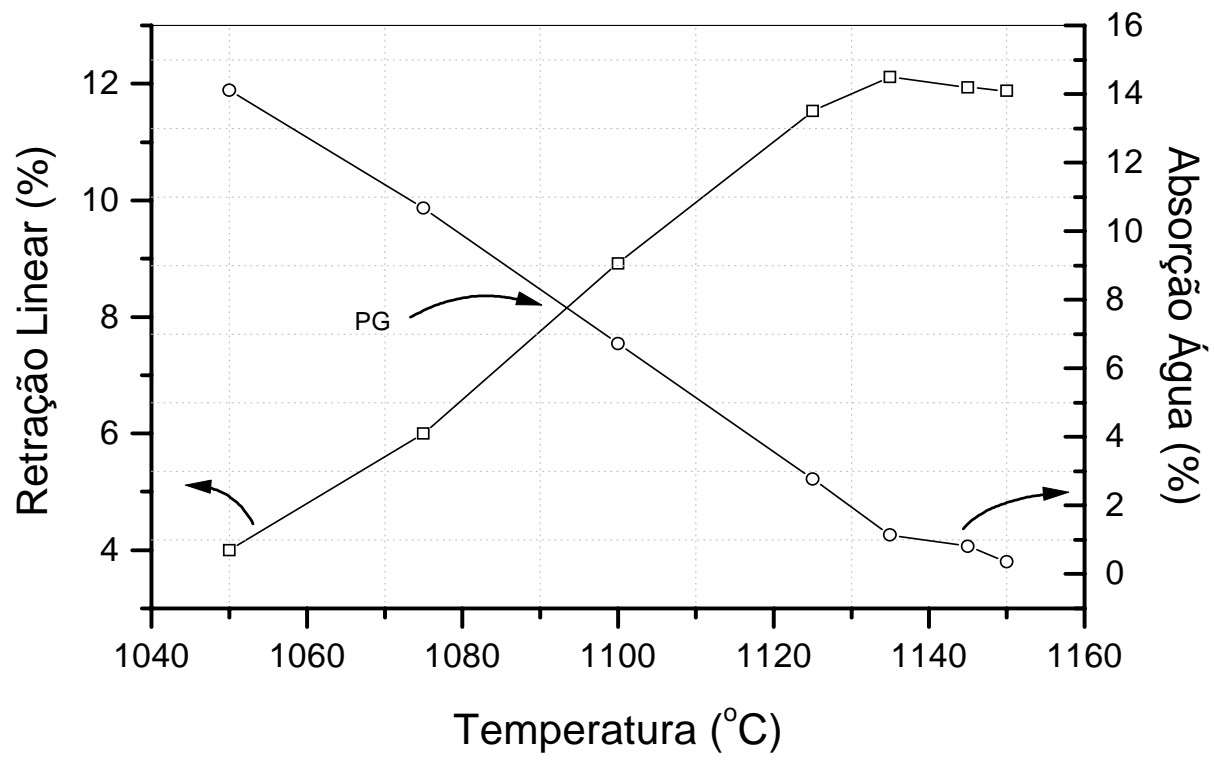

Figura 10: Curva de gresificação de placa cerâmica de massa típica.

Entre $550^{\circ} \mathrm{C}$ e $800^{\circ} \mathrm{C}$ se inicia a decomposição dos minerais argilosos, através de reações químicas da sílica e da alumina, com os elementos fundentes, formando complexos sílico-aluminatos, que conferem dureza, resistência e estabilidade à placa cerâmica. $800^{\circ} \mathrm{C}$ até $950^{\circ} \mathrm{C}$, podem ser associados à perda de estrutura cristalina (ilitas) formação de espinélios, podendo ainda, ser associados a nucleação de mulita, dependendo da composição mineralógica das matérias-primas. Acima de $1000^{\circ} \mathrm{C}$ 
começam a aparecer as fases líquidas, que promoverão a sinterização das partículas da placa. Essas reações, promovendo-se no estado sólido, necessitam de tempo adequado para se promover. Nessa forma, é imprescindível que esse fator seja controlado, principalmente quando a placa for composta por massa obtida via seca, uma vez que esse processo de obtenção de massa não apresenta grande homogeneidade dos constituintes. 


\section{MATERIAIS E MÉTODOS}

\subsection{TÉCNICAS E MÉTODOS ANALÍTICOS}

A metodologia adotada para este estudo de caso foi a de caracterização e classificação dos resíduos com possibilidades de reciclagem, por incorporação ao próprio processo de fabricação das placas, compreendendo os resíduos da ETARI, também conhecidos como "lama” e os resíduos provenientes de peças queimadas fora de especificação, aqui chamados de resíduos queimados, que são vulgarmente conhecidos como “cacos”. Após esse procedimento, foram realizados os ensaios tecnológicos por incorporação dos resíduos em diversas concentrações, verificandose as propriedades físico-químicas dos corpos de prova, comparando-se aos corpos de prova padrão. As amostras de resíduo de ETARI foram coletadas do tanque de decantação de acordo com a norma NBR 10007. As amostras de resíduo queimado foram obtidas a partir da moagem de placas cerâmicas escolhidas ao acaso na linha de produção, sendo definidas como fração 1, a fração dos resíduos que passou pela peneira malha 50 (0,3mm), e fração 2, a fração dos resíduos que passou pela peneira malha $200(0,074 \mathrm{~mm})$. As amostras de massa cerâmica padrão foram coletadas na saída do alimentador da prensa.

Optou-se por utilizar adições de resíduos entre 1\% a 10\% em peso, devido ao volume de resíduos disponível à indústria, e à natureza dos resíduos de ETARI que, por terem se originados na etapa de esmaltação, podem imprimir alterações significativas quanto ao controle dimensional das peças cerâmicas. As misturas foram obtidas por mistura a seco das quantidades referentes a cada adição, em porcentagem em peso.

Para se avaliar as propriedades mecânicas de amostras da massa cerâmica contendo adições dos resíduos queimados, devido à natureza mineralógica dos mesmos, foram escolhidas as temperaturas de queima, em função da curva de gresificação da massa cerâmica padrão, de $1125^{\circ} \mathrm{C}, 1100^{\circ} \mathrm{C}, 1075^{\circ} \mathrm{C}$ e $1050^{\circ} \mathrm{C}$. A Incefra promove ciclos de queima com temperatura inferior de 1050 e temperatura superior de $1100^{\circ} \mathrm{C}$. 


\subsubsection{Caracterização e classificação dos resíduos.}

A caracterização dos resíduos e da massa cerâmica foi elaborada com o objetivo de se levantar informações sobre seu comportamento físico-químico determinando-se, desse modo, as condições ideais para a incorporação desses resíduos à massa cerâmica, sem prejudicar a qualidade das placas obtidas e, a partir das informações levantadas, realizar a classificação dos resíduos dentro das normas competentes.

\subsubsection{Determinação da composição mineralógica por $D R X$}

A caracterização mineralógica dos resíduos e da massa cerâmica foi realizada utilizando-se de medidas de difração de raios X, obtidas em difratômetro SIEMENS 5000D, pelo método de pó, com amostra não orientada, identificando-se as linhas de difração através de fichas cristalográficas PDF como padrões. Foram analisadas amostras da massa cerâmica padrão e dos resíduos de ETARI e queimado, secas em estufa a $100^{\circ} \mathrm{C}$ por 24 horas, desaglomeradas e passadas em peneira malha 200, e amostras submetidas a tratamento térmico de $500^{\circ} \mathrm{C}$ por 30 minutos.

\subsubsection{Determinação da composição mineralógica por FTIR.}

A determinação da composição mineralógica dos resíduos e da massa cerâmica, utilizando-se medidas de Infravermelho com transformada de Fourrier, foi necessária, uma vez que as análises de DRX detectaram somente os elementos majoritários. Foram preparadas as amostras, na forma de discos, por mistura com Iodeto de Césio (CsI) como padrão, na proporção 1:100 de CsI, prensados com pressão de 10 toneladas $/ \mathrm{cm}^{2}$, e ensaiados com espectrofotômetro SHIMADSU, com resolução de $4 \mathrm{~cm}^{-1}$ e limites de número de onda de $200 \mathrm{~cm}^{-1}$ à $4000 \mathrm{~cm}^{-1}$, sendo os dados tratados pelo software de trabalho WIN-BOMEN EASY. A determinação das espécies mineralógicas presentes foi realizada através de comparação com estudos 
padrões constantes na literatura. Foram analisadas as amostras secas em estufa a $100^{\circ} \mathrm{C}$ por 24 horas e calcinadas em $500^{\circ} \mathrm{C}$ por 30 minutos.

\subsubsection{Determinação da composição química.}

As composições químicas foram determinadas por medidas de EDX, em amostras na forma de discos resultantes da prensagem de mistura do resíduo e de CsI, na proporção de 25:1 de CsI, que foi utilizado como ligante apropriado, uma vez que as espécies a serem investigadas não coincidiam com o CsI. Esses discos foram fixados em suporte de alumínio e receberam uma camada de carbono grafite, para servir de eletrodo, realizando as medidas através de um microscópio eletrônico de varredura com sistema de espectroscopia dispersiva de raios-X LEO 440. Os dados foram tratados por método quantitativo, utilizando o software ZAF, que analisa todos os elementos e normaliza os resultados, utilizando detector de SiLi, com resolução do sistema de $112 \mathrm{eV}$.

\subsubsection{Determinação da granulometria dos pós.}

As análises granulométricas foram realizadas conforme norma brasileira NBR 7181 de 1987, pelo processo de sedimentação e peneiramento conjunto, onde basicamente, uma amostra de $150 \mathrm{~g}$ de cada material a ser ensaiado foi submetida a defloculação em $125 \mathrm{~mL}$ de solução de hexametafosfato de sódio com concentração 45,7g/L, durante 24h. Em seguida, promoveu-se uma agitação por 15 minutos em agitador tipo mixer e adicionou-se a uma proveta de $1000 \mathrm{~mL}$, completando-se o volume até $1000 \mathrm{~mL}$ com água destilada. Utilizando-se de uma planilha de ensaio, foram efetuadas medidas de densidade da amostra, em diversos tempos característicos da sedimentação de determinados tamanhos de grãos, fazendo-se correções para o valor embutido da densidade do defloculante. Após o tempo determinado de ensaio, a mistura foi passada em peneira malha 200 e secou-se o material retido em estufa, por 24h, sendo separada em peneiras malhas 50, 100 e 200 e pesada, utilizando-se o software Microsoft Excel para o tratamento dos dados e obtenção dos gráficos de granulometria. 


\subsubsection{Determinação da Superfície específica}

As áreas superficiais das amostras foram determinadas por medidas de isotermas de absorção/desorção de nitrogênio, utilizando-se equipamento ASAP 2000 Micromerits, sendo os dados tratados por software Origin 5.0.

\subsubsection{Análises Térmicas}

As análises térmicas diferenciais (ATD) foram realizadas em um termoanalisador $\mathrm{NETZCH}$, com intervalo de temperatura entre $30^{\circ} \mathrm{C}$ e $1250^{\circ} \mathrm{C}$, em atmosfera de ar sintético com fluxo constante de $30 \mathrm{~cm}^{3} / \mathrm{min}$, em cadinho de alumina, utilizando-se um cadinho vazio (ar) como referência e os dados foram tratados por software Origin 5.0, utilizando-se dados da literatura para a análise dos resultados.

\subsubsection{Determinação da Toxicidade pelo método de lixiviação}

A classificação dos resíduos quanto à sua toxicidade foi realizada através do método de lixiviação. Esta análise foi determinada conforme as normas NBR 10004, NBR 10005 e NBR 10007, sendo realizada em triplicata para cada resíduo. As análises de absorção atômica das amostras do extrato (lixiviado) dos resíduos da ETARI e queimado, respectivamente, resultantes das lixiviações dos resíduos, foram realizadas em um espectrofotômetro Z8100 Polarized Zeeman Atomic Absorption Spectrophotometer. As concentrações dos elementos presentes nas amostras foram comparadas com as concentrações padrões constantes nas normas acima citadas e classificadas mediante os termos de classificação. 


\subsubsection{Determinação da Toxicidade pelo método de Bioteste}

Para se avaliar a toxicidade por bioteste, foram preparadas amostras por lixiviação, de acordo com as normas NBR 10004, NBR 10005 e NBR 10007, dos resíduos de ETARI e queimado, bem como da massa cerâmica contendo adição de 10\% em peso de resíduo queimado fração 2 e 10\% em peso de resíduo de ETARI, que foram denominadas, respectivamente, BIOT 1R, BIOT 2R, BIOT 3R e BIOT 4R.

Os testes de toxicidade com o lixiviado das amostras BIOT 1R, BIOT 2R, BIOT 3R, BIOT 4R e ácido acético $0,5 \mathrm{~N}$, foram realizados de acordo com os procedimentos descritos em CETESB (1990), L5.018, sendo realizado em triplicata para cada resíduo.

O princípio do método consiste na exposição de organismos jovens (neonatos) de Daphnia similis (crustáceo) às diferentes concentrações da amostra durante 48 horas nas condições prescritas. Após o período de exposição, procede-se à contagem dos organismos imóveis, sendo assim considerados aqueles que não conseguiram nadar após leve agitação da amostra. A concentração efetiva inicial média, que causa efeito adverso em $50 \%$ dos organismos teste, CE(I) $50 ; 48 \mathrm{~h}$, foi calculada através do método estatístico Trimmed Spearman-Karber.

\subsubsection{Determinação dos Ensaios Tecnológicos}

O estudo tecnológico consistiu na avaliação das propriedades mecânicas de corpos de prova da massa cerâmica padrão, isenta de resíduos, e da avaliação das propriedades mecânicas de corpos de prova contendo adições de 1, 2, 3, 4, 5, e 10\% em peso de resíduos de ETARI, analogamente, de resíduo queimado, frações 1 e 2, de acordo com as tabelas 08a, 08b e 08c. Para se determinar a possibilidade do uso conjunto de resíduos de ETARI e queimado, foram avaliadas as propriedades mecânicas de duas composições, de acordo com a tabela 09. 
Inicialmente, foram avaliadas as propriedades mecânicas, de peças sem adição do resíduo, por determinação da curva de gresificação da massa cerâmica padrão, utilizando os dados de porcentagem de retração linear, porcentagem de absorção de água e módulo de resistência à flexão em três pontos.

Tabela 08a: Composição das misturas da massa cerâmica padrão contendo adições isoladas de resíduo de ETARI.

\begin{tabular}{|c|c|c|c|c|c|c|}
\hline Mistura & \multicolumn{5}{|c|}{ (\% em peso) } \\
\hline $\begin{array}{c}\text { Massa cerâmica } \\
\text { padrão }\end{array}$ & $99 \%$ & $98 \%$ & $97 \%$ & $96 \%$ & $95 \%$ & $90 \%$ \\
\hline Resíduo ETARI & $1 \%$ & $2 \%$ & $3 \%$ & $4 \%$ & $5 \%$ & $10 \%$ \\
\hline
\end{tabular}

Tabela 08b: Composição das misturas da massa cerâmica padrão contendo adições isoladas de resíduo Queimado Fração 1.

\begin{tabular}{|c|c|c|c|c|c|c|}
\hline Mistura & \multicolumn{5}{|c|}{ (\% em peso) } \\
\hline $\begin{array}{c}\text { Massa cerâmica } \\
\text { padrão }\end{array}$ & $99 \%$ & $98 \%$ & $97 \%$ & $96 \%$ & $95 \%$ & $90 \%$ \\
\hline $\begin{array}{c}\text { Resíduo queimado } \\
\text { Fração 1 }\end{array}$ & $1 \%$ & $2 \%$ & $3 \%$ & $4 \%$ & $5 \%$ & $10 \%$ \\
\hline
\end{tabular}

Tabela 08c: Composição das misturas da massa cerâmica padrão contendo adições isoladas de resíduo Queimado Fração 2.

\begin{tabular}{|c|c|c|c|c|c|c|}
\hline Mistura & \multicolumn{5}{|c|}{ (\% em peso) } \\
\hline $\begin{array}{c}\text { Massa cerâmica } \\
\text { padrão }\end{array}$ & $99 \%$ & $98 \%$ & $97 \%$ & $96 \%$ & $95 \%$ & $90 \%$ \\
\hline $\begin{array}{c}\text { Resíduo queimado } \\
\text { Fração 2 }\end{array}$ & $1 \%$ & $2 \%$ & $3 \%$ & $4 \%$ & $5 \%$ & $10 \%$ \\
\hline
\end{tabular}


Tabela 09: Composição das misturas da massa cerâmica padrão contendo adições simultâneas dos resíduos de ETARI e queimado.

\begin{tabular}{|c|c|c|}
\hline Mistura & \multicolumn{2}{|c|}{ (\% em peso) } \\
\hline Massa cerâmica padrão & $94 \%$ & $80 \%$ \\
\hline Resíduo ETARI & $3 \%$ & $10 \%$ \\
\hline Resíduo queimado Fração 1 & $3 \%$ & $10 \%$ \\
\hline
\end{tabular}

A partir do ponto de gresificação da amostra padrão, foram determinadas as temperaturas de queima, para avaliar as propriedades mecânicas das peças contendo adições dos resíduos.

\subsubsection{Obtenção e queima dos corpos de prova.}

Foram prensados corpos de provas com massa de 14,0g e dimensões iniciais (a verde) de 70x20x5mm, com pressão uniaxial de $321 \mathrm{kgf} / \mathrm{cm}^{2}$, das amostras de massa cerâmica padrão e contendo adições de 1, 2, 3,4, 5 e 10\% em peso de resíduos de ETARI, e com concentrações análogas de resíduos queimados. Após secagem em estufa a $100^{\circ} \mathrm{C}$ por 24 horas, as amostras da massa padrão foram submetidas a tratamento térmico em forno de laboratório tipo EDG 3P, em temperaturas de $1135^{\circ} \mathrm{C}, 1125^{\circ} \mathrm{C}, 1100^{\circ} \mathrm{C}, 1075^{\circ} \mathrm{C}, 1050^{\circ} \mathrm{C}$ e $1025^{\circ} \mathrm{C}$, com taxa de aquecimento de $10^{\circ} \mathrm{C} / \mathrm{min}$ até $1000^{\circ} \mathrm{C}$ e $5^{\circ} \mathrm{C} / \mathrm{min}$ até a temperatura desejada, permanecendo em patamar de 10 minutos na máxima temperatura, sendo resfriadas gradualmente, na taxa de resfriamento do forno, estando ele fechado até atingir temperatura ambiente.

As amostras contendo adições de resíduos de ETARI foram submetidas aos ciclos térmicos descritos anteriormente, mas em temperaturas de $1125^{\circ} \mathrm{C}, 1100^{\circ} \mathrm{C}$, $1075^{\circ} \mathrm{C}$, e $1025^{\circ} \mathrm{C}$, e as temperaturas dos ciclos de queima das amostras contendo adições de resíduos foram $1125^{\circ} \mathrm{C}, 1100^{\circ} \mathrm{C}, 1075^{\circ} \mathrm{C}$, e $1050^{\circ} \mathrm{C}$.

Utilizaram-se 5 amostras queimadas por temperatura de queima de cada composição da massa cerâmica e 5 amostras a seco para determinação dos módulos de resistência à flexão queimado e a seco. Foram analisadas 35 amostras da massa 
cerâmica padrão, 150 amostras contendo adições isoladas de cada tipo de resíduo e 50 amostras contendo adições conjuntas dos resíduos, totalizando 535 amostras.

Para a avaliação tecnológica, as amostras foram submetidas aos ensaios específicos para cada propriedade desejada.

4.1.2.2. Determinação da porcentagem de absorção de água, densidade aparente e porosidade aparente.

As determinações de porcentagem de absorção de água, densidade aparente e porosidade aparente, foram realizadas utilizando-se o método de Archimmedes, que se baseia na mensuração da massa seca, imersa e úmida de cada amostra queimada, onde uma relação matemática entre essas grandezas resulta nos dados de porcentagem de absorção de água, densidade aparente e porosidade aparente. Essas relações matemáticas são apresentadas pelas equações (1), (2) e (3), onde PS, PU, PI, AA, DA, PA e $\rho_{\mathrm{L}}$ significam, respectivamente, peso seco, peso úmido, peso imerso, absorção de água, densidade aparente , porosidade aparente e densidade do meio líquido.

Absorção de água:

$$
\mathrm{AA}(\%)=[(\mathrm{PU}-\mathrm{PS}) / \mathrm{PS}] \times 100
$$

Porosidade aparente:

$$
\mathrm{PA}(\%)=[(\mathrm{PU}-\mathrm{PS}) /(\mathrm{PU}-\mathrm{PI})] \times 100
$$

Densidade aparente:

$$
\mathrm{DA}\left(\mathrm{g} / \mathrm{cm}^{3}\right)=\left[(\mathrm{PS} /(\mathrm{PU}-\mathrm{PI})] \times \rho_{\mathrm{L}}\right.
$$

\subsubsection{Determinação da porcentagem de retração linear.}

Para a determinação da porcentagem de retração linear, foram medidas as amostras de massa cerâmica padrão e contendo adições de resíduos queimados e de 
ETARI, a verde, após secagem em estufa a $100^{\circ} \mathrm{C}$ por $24 \mathrm{~h}$, e após tratamento térmico nas temperaturas determinadas. Através da relação matemática apresentada na equação (4), pôde-se obter os valores de retração linear dos corpos de prova, onde $\mathrm{L}_{V}, \mathrm{~L}_{\mathrm{S}}, \mathrm{Lq}$ e RL significam, respectivamente, comprimento do corpo de prova a verde, seco e queimado, respectivamente, e retração linear. Através da equação (4) determinaram-se os valores de RL verde-seco, para as amostras secas a $100^{\circ} \mathrm{C}$ e através da equação (5) determinaram-se os valores de RL seco-queimado, para as amostras queimadas nas temperaturas descritas no item 4.1.2.1.

$$
\begin{gathered}
\mathrm{RL}(\%)=\left[\left(\mathrm{L}_{\mathrm{V}}-\mathrm{L}_{\mathrm{S}}\right) /\left(\mathrm{L}_{\mathrm{V}}\right)\right] \times 100 \\
\mathrm{RL}(\%)=\left[\left(\mathrm{L}_{\mathrm{S}}-\mathrm{Lq}\right) /\left(\mathrm{L}_{\mathrm{S}}\right)\right] \times 100
\end{gathered}
$$

\subsubsection{Determinação do módulo de ruptura à flexão 3 pontos}

A resistência mecânica foi avaliada, através de ensaios de determinação do módulo de ruptura à flexão em três pontos, utilizando um tensômetro HOUNSFIELD, mantendo velocidade constante $(0,5 \mathrm{~mm} / \mathrm{min})$ até a fratura da amostra, sendo os resultados calculados através da equação (6).

$$
\operatorname{MRF}\left(\mathrm{kgf} / \mathrm{cm}^{2}\right)=(3 \mathrm{~F} \times \mathrm{L}) /\left(2 \mathrm{~b} \times e^{2}\right)
$$

Onde:

MRF é o módulo de resistência à flexão, em kgf/ $\mathrm{cm}^{2}$;

F é a força de ruptura, em kgf;

L é a distância entre as barras de apoio, em centímetros;

b é a largura do corpo de prova, em centímetros;

$e$ é a espessura do corpo de prova, em centímetros. 


\section{RESULTADOS E DISCUSSÕES.}

\subsection{CARACTERIZAÇÃO DA MASSA CERÂMICA E DOS RESÍDUOS EM ESTUDO.}

\subsubsection{Identificação mineralógica por Difração de Raios $X$}

A caracterização de minerais (ou fases) pode ser efetuada com o auxílio da difração de raios X (DRX). As substâncias amorfas com carência de periodicidade nos arranjos atômicos (iônicos ou moleculares) já não podem ser caracterizadas, ou, em casos especiais, o são com grande dificuldade.

Em alguns casos, substâncias isomórficas podem ser confundidas por apresentar valores de $d$ muito próximos. Os minerais diferem consideravelmente em relação aos difratogramas que apresentam. De acordo com SANTOS (1966), uma mistura de argilominerais de grupos diferentes sempre apresenta dificuldades, podendo não ser possível a completa identificação da amostra, principalmente quando um constituinte a ser identificado existe em pequeno teor na amostra e suas linhas de interferência no difratograma estão mascaradas pelos argilominerais predominantes.

Observa-se nas análises de DRX da massa cerâmica (Figura 11), a presença de Quartzo, Ilita, Caulinita, e Albita, espécies majoritárias, características da formação geológica de Corumbataí (região de Santa Gertrudes).

Com o objetivo de acompanhar as transformações das espécies componentes da massa cerâmica, foi realizada uma análise de DRX com amostra calcinada em $500^{\circ} \mathrm{C}$ por 30 minutos, resultando no difratograma da figura 12. Pode-se observar que nessa temperatura a amostra não apresenta mudanças significativas, apenas uma leve diminuição no grau de cristalinidade observada pelo alargamento da base e vizinhança dos picos de difração, devido à desidratação de alguns hidróxidos, como o $\mathrm{Al}_{2}(\mathrm{OH})_{3}$.

As análises de raios-X dos resíduos queimados, (Figura 13), apresentaram as fases cristalinas Quartzo (syn) e Mulita, sendo observado a presença de um complexo vítreo, característico de argilas queimadas. Esses resíduos não apresentaram alterações quando calcinados em $500^{\circ} \mathrm{C}$ por 30 minutos, devido ao caráter inerte da sua composição química (Figura 14). 


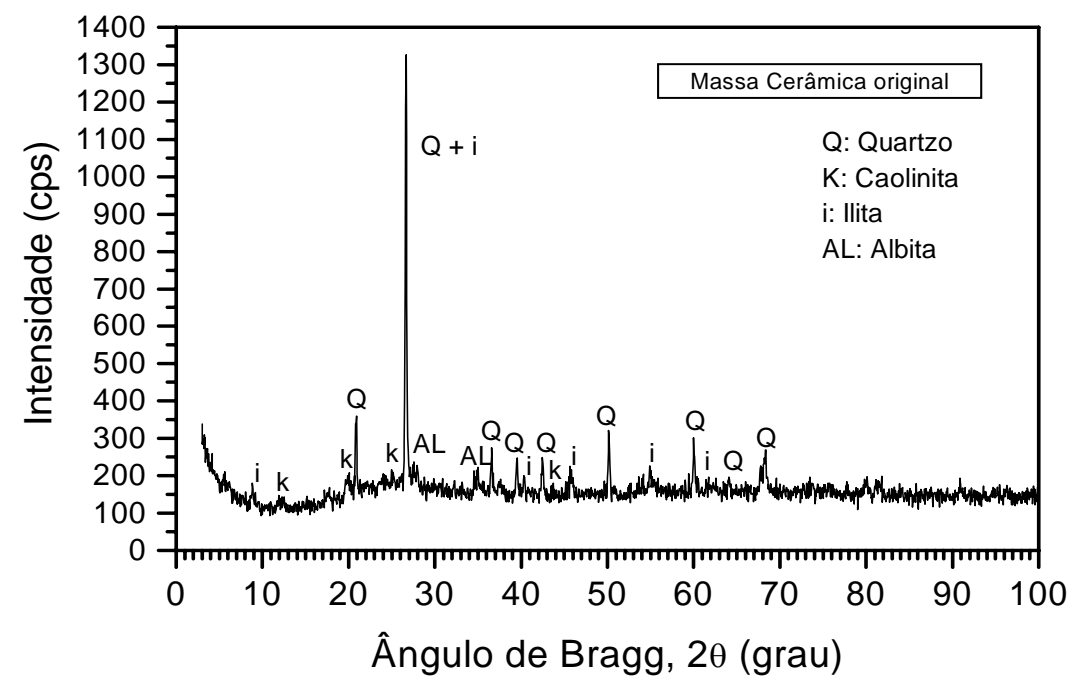

Figura 11: Difratograma de raios-X da massa cerâmica.

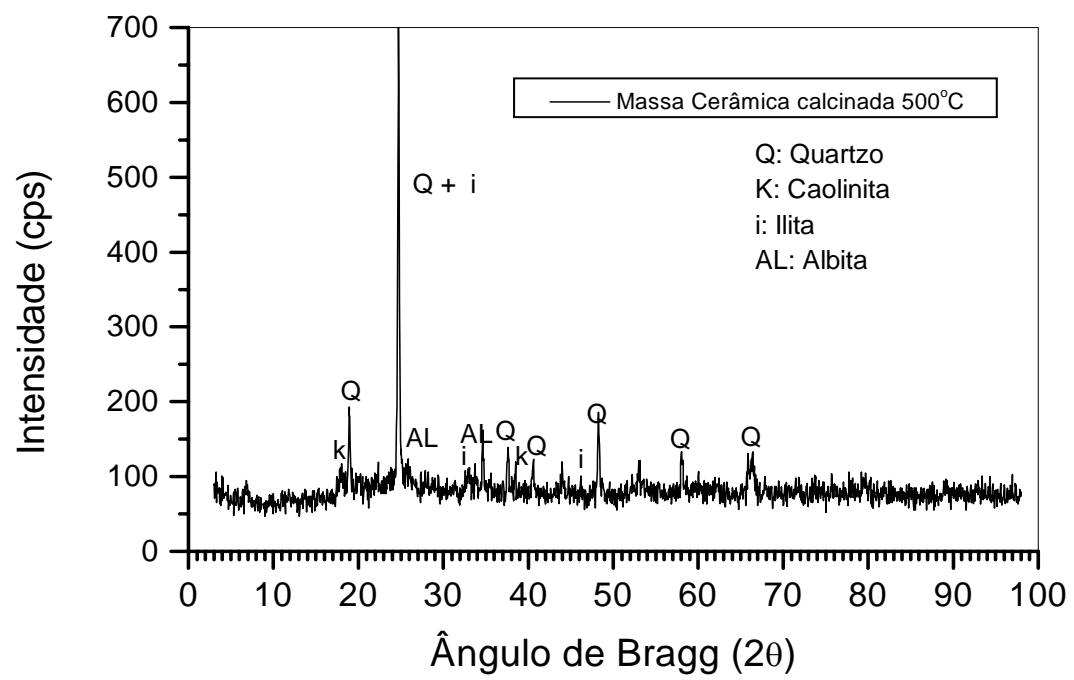

Figura 12: Difratograma de raios-X da massa cerâmica típica calcinada $500^{\circ} \mathrm{C}$ por 30 minutos.

Os resíduos das ETARIs (Figura 15) apresentaram, além de Quartzo (syn), Ilita, Caulinita, que constituem a massa cerâmica, a presença de Anatase, Calcita e material amorfo componente dos vidrados. Determinar a composição das lamas 
através de difração de raios-X é realmente muito difícil, uma vez que são muitas espécies de óxidos inorgânicos, constituintes dos corantes dos vidrados, em quantidades pequenas e/ou de baixa cristalinidade para serem detectados por DRX.

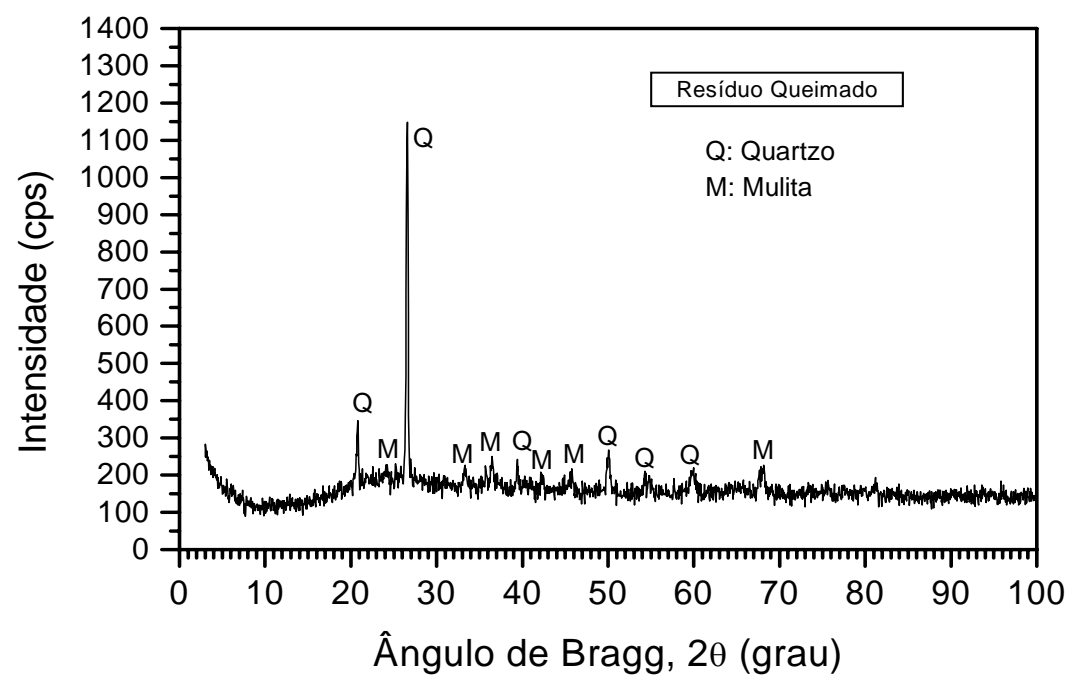

Figura 13: Difratograma de raios-X da amostra de resíduo queimado.

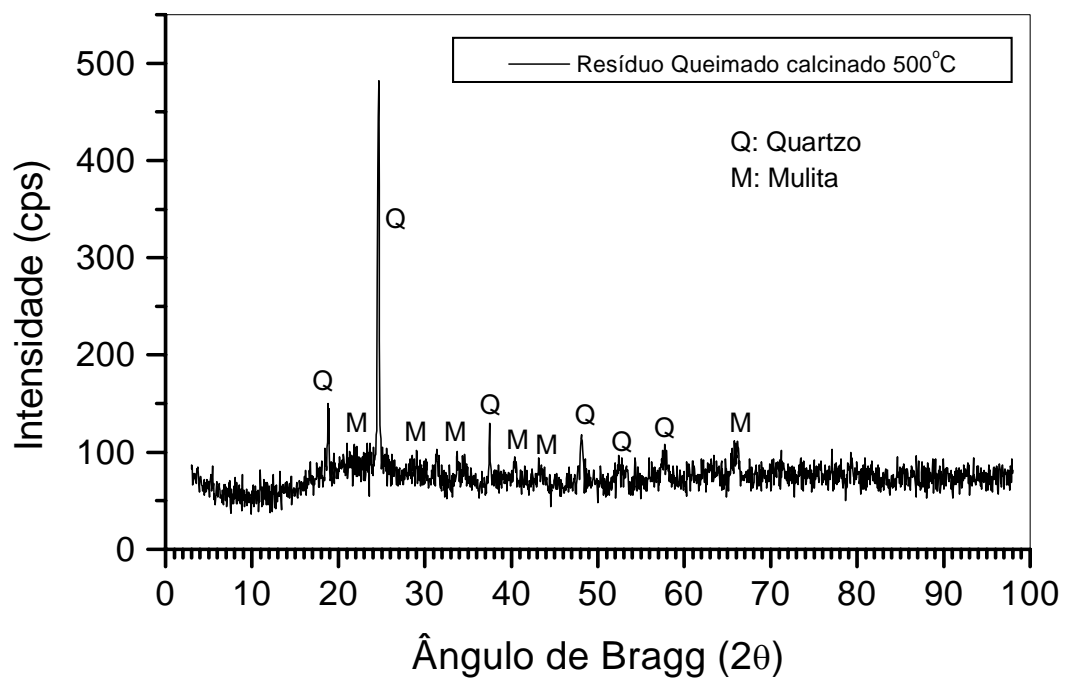

Figura 14: Difratograma de raios-X do resíduo queimado calcinado em $500^{\circ} \mathrm{C}$ por 30 minutos. 
A amostra calcinada em $500^{\circ} \mathrm{C}$ apresentou significativa diminuição da intensidade de reflexão para a Calcita (Figura 16), uma vez que ocorre a decomposição térmica nessa temperatura, ela ainda é detectada porque o tempo não foi suficiente para a completa decomposição; também pode ser observado o efeito da desidratação das espécies hidroxiladas, resultando no aumento da banda na região de menor ângulo de incidência do feixe da radiação.

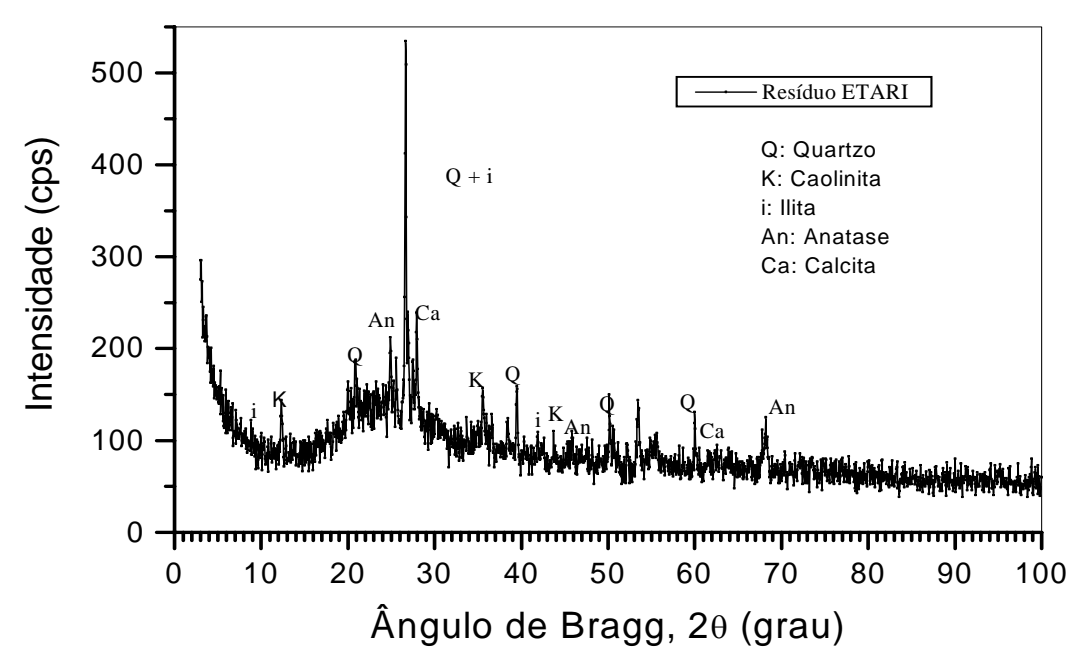

Figura 15: Difratograma de raios X da amostra de resíduo da ETARI.

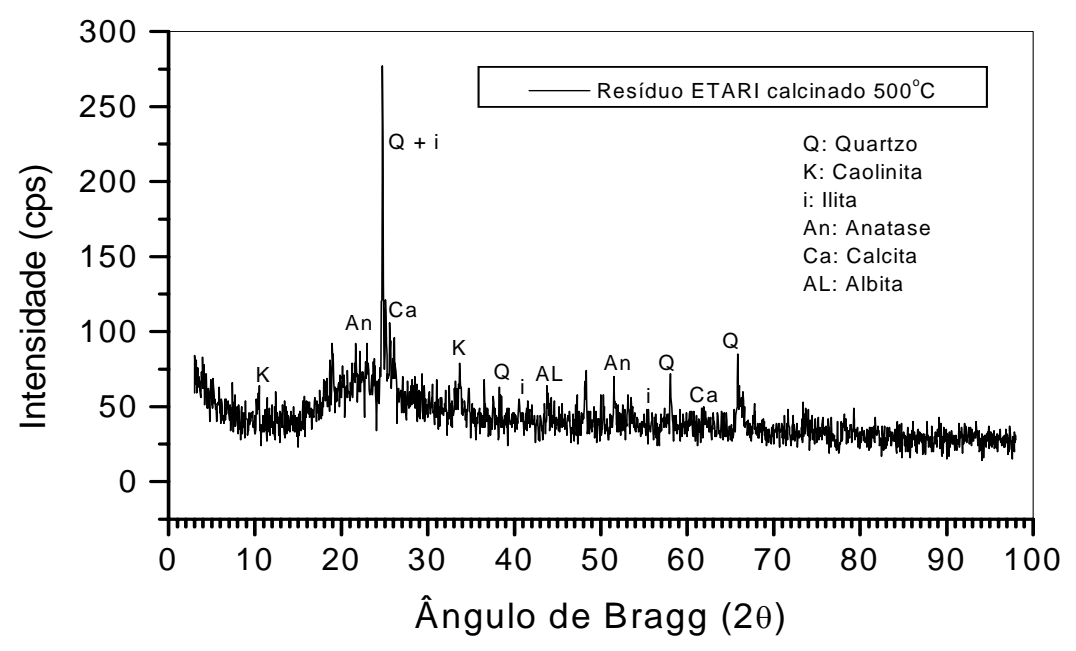

Figura 16: Difratograma de raios $\mathrm{X}$ da amostra de resíduo da ETARI, calcinada em $500^{\circ} \mathrm{C}$ por 30 minutos. 
Os resultados das análises de raios-X puderam ser compreendidos melhor com o auxílio de análises de espectroscopia de infravermelho, sendo possível a detecção de espécies amorfas.

\subsubsection{Análise de composição mineralógica por espectroscopia de Infravermelho.}

\subsubsection{Massa Cerâmica.}

As bandas de deformação e bandas de baixa freqüência da rede são de difícil identificação em espectros de argilas ricas em silicatos, mas as bandas de estiramento O-H são usualmente diagnosticadas de um oxi-hidróxido mineral, após a remoção de água adsorvida.

O espectro de IR da massa cerâmica, (Figura 17), apresenta claramente o dubleto agudo de O-H característico de caolinita bem cristalizada em $3697 \mathrm{~cm}^{-1}$ e $3620 \mathrm{~cm}^{-1}$, com suporte das bandas sobre 797, 696 e $277 \mathrm{~cm}^{-1}$.

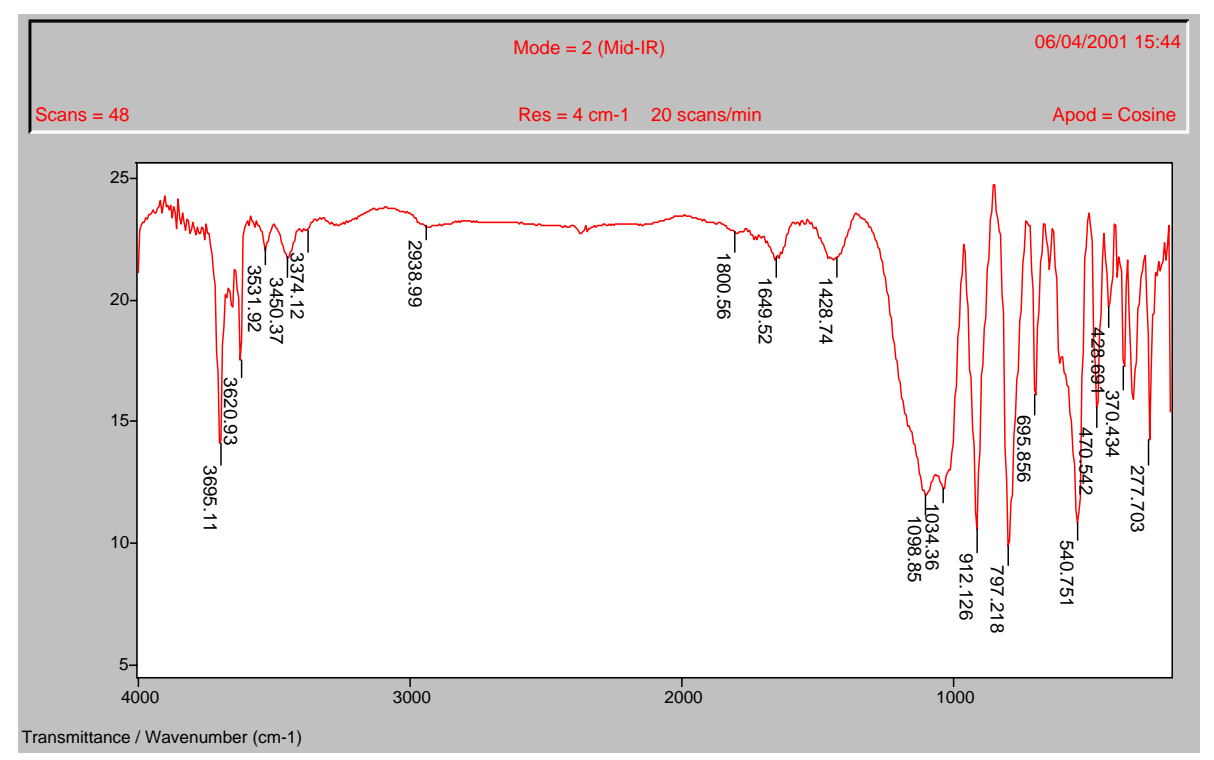

Figura 17: Espectro de FTIR de amostra da massa cerâmica seca em estufa a $100^{\circ} \mathrm{C}$ por 24 horas. 
Com a amostra seca, é possível observar bandas alargadas ao redor de 3531 $\mathrm{cm}^{-1}, 3450 \mathrm{~cm}^{-1}$ e $350 \mathrm{~cm}^{-1}$, que caracterizam a presença de Ilita, mesmo sem a predominância das bandas em 750 e $680 \mathrm{~cm}^{-1}$, que são mascaradas por bandas próximas alargadas e intensas. Devido a esse fato, não é possível identificar o tipo de ilita presente na massa cerâmica utilizando espectroscopia de infravermelho.

As bandas em 1009 e $471 \mathrm{~cm}^{-1}$ são marcadas por deformação Si-O, consistentes da presença de clorita contendo ferro. O alargamento abaixo da linha de absorção na região de $\mathrm{O}-\mathrm{H}$, centrada sobre $3300 \mathrm{~cm}^{-1}$ e uma banda na região de 1650 $\mathrm{cm}^{-1}$, sugere que um aluminossilicato amorfo (Alofano) pode estar presente.

Uma discreta banda em torno de $1800 \mathrm{~cm}^{-1}$ é causada por matéria orgânica, que aparece em pouca quantidade.

A presença de gibsita é diagnosticada através do padrão de bandas de estiramento O-H, que apresenta um dubleto em $3391 \mathrm{~cm}^{-1}$ e $3373 \mathrm{~cm}^{-1}$ (Figura 18). Isto não é sempre observado, mas o quarteto de bandas à 3620, 3527, 3464 e 3380 $\mathrm{cm}^{-1}$, e a $1017 \mathrm{~cm}^{-1}$ juntamente com a $366 \mathrm{~cm}^{-1}$ são observadas, desaparecendo após aquecimento a $350^{\circ} \mathrm{C}$, comportamento que caracteriza a presença de gibsita.

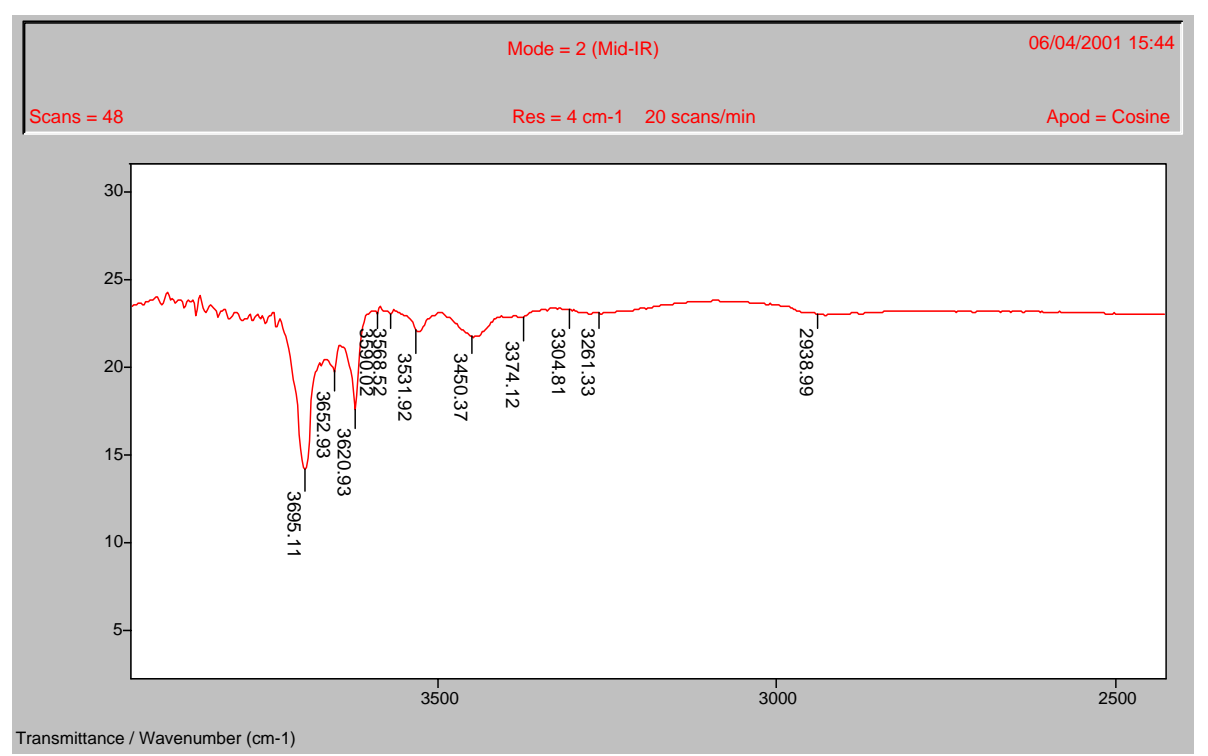

Figura 18: Detalhe da região de alta freqüência do espectro de FTIR de amostra da massa cerâmica seca em estufa a $100^{\circ} \mathrm{C}$ por 24 horas. 
O quartzo é um constituinte comum da maioria dos argilominerais. Sua identificação é facilmente feita pelas bandas, em dubleto, em 800 e $781 \mathrm{~cm}^{-1}$, 516 e $460 \mathrm{~cm}^{-1}$ e 399 e $370 \mathrm{~cm}^{-1}$, além de uma banda simples em $1078 \mathrm{~cm}^{-1}$ e outra em 694 $\mathrm{cm}^{-1}$ (Figuras 19 e 20).

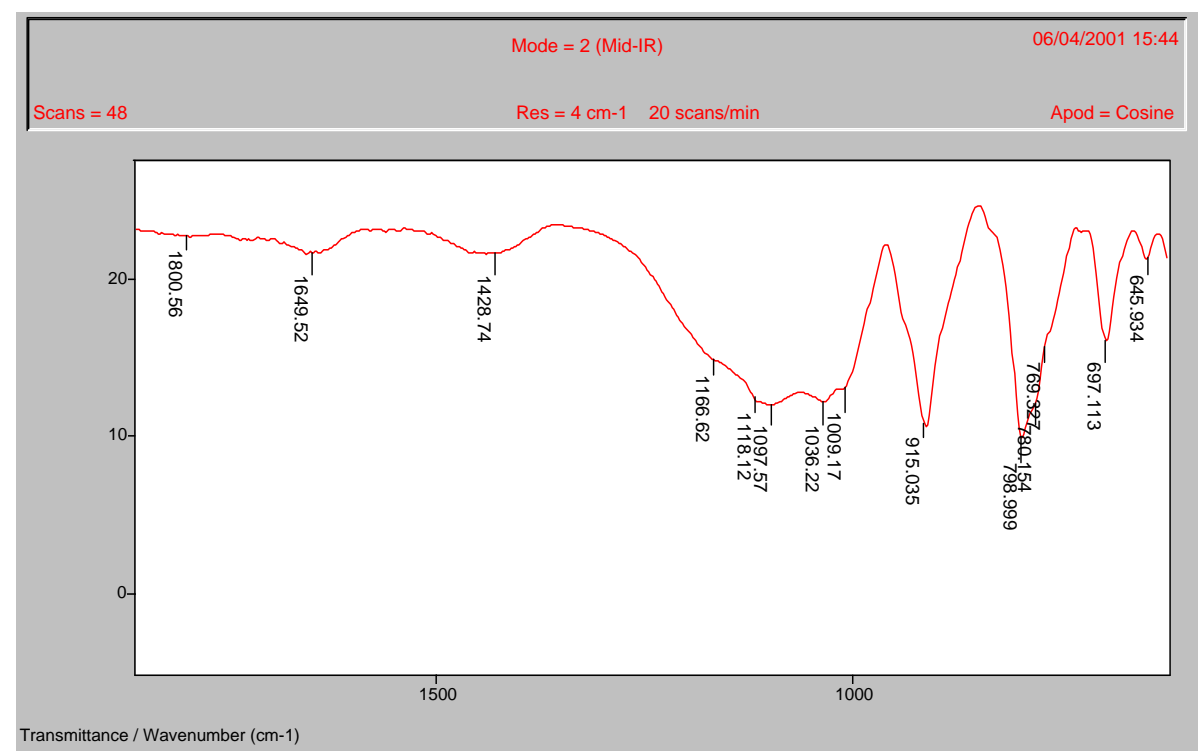

Figura 19: Detalhe da região de freqüência entre $1800 \mathrm{~cm}^{-1}$ e $640 \mathrm{~cm}^{-1}$ do espectro de FTIR de amostra da massa cerâmica seca em estufa a $100^{\circ} \mathrm{C}$ por 24 horas.

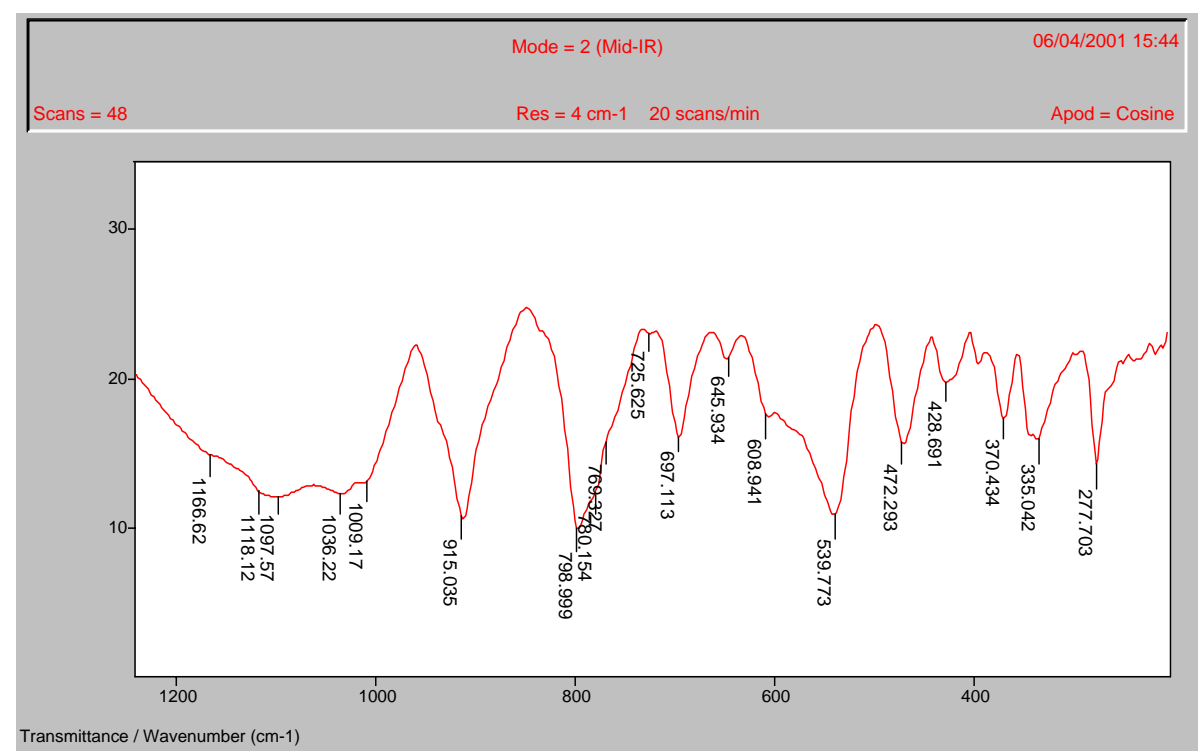

Figura 20: Detalhe da região de freqüência entre $1200 \mathrm{~cm}^{-1}$ e $200 \mathrm{~cm}^{-1}$ do espectro de FTIR de amostra da massa cerâmica seca em estufa a $100^{\circ} \mathrm{C}$ por 24 horas. 
A calcita é o carbonato mais comum em argilominerais, apresentando bandas características em 1428, 878 e $714 \mathrm{~cm}^{-1}$. Na amostra da massa cerâmica, é possível identificar a banda alargada em $1428 \mathrm{~cm}^{-1}$, sendo que as demais bandas ficam sobrepostas com outras bandas na mesma região.

A massa cerâmica, ao ser calcinada a $500^{\circ} \mathrm{C}$ por 30 minutos, apresenta uma nova composição química, visto que ocorrem algumas reações em temperaturas inferiores e, também, nessa temperatura, de acordo com resultados de análise térmica diferencial. É previsto que, nessa temperatura, já tenha ocorrido a eliminação de água adsorvida, bem como a desidroxilação de alguns hidróxidos e óxidos hidratados, como o de alumínio $\mathrm{Al}_{2}(\mathrm{OH})_{3}$. Porém o processo de desidroxilação das argilas ilíticas e caoliníticas ainda está ocorrendo, uma vez que o intervalo para esse processo nessas argilas é de $400^{\circ} \mathrm{C}$ à $600^{\circ} \mathrm{C}$.

Deste modo, o espectro de IR da massa cerâmica calcinada a $500^{\circ} \mathrm{C}$ (Figura 21) apresenta a ausência do quarteto de bandas a 3620, 3527, 3464 e $3380 \mathrm{~cm}^{-1}$, e a $1017 \mathrm{~cm}^{-1}$ juntamente com a $366 \mathrm{~cm}^{-1}$, que caracterizam a presença de gibsita, que decompõe em $350^{\circ} \mathrm{C}$.

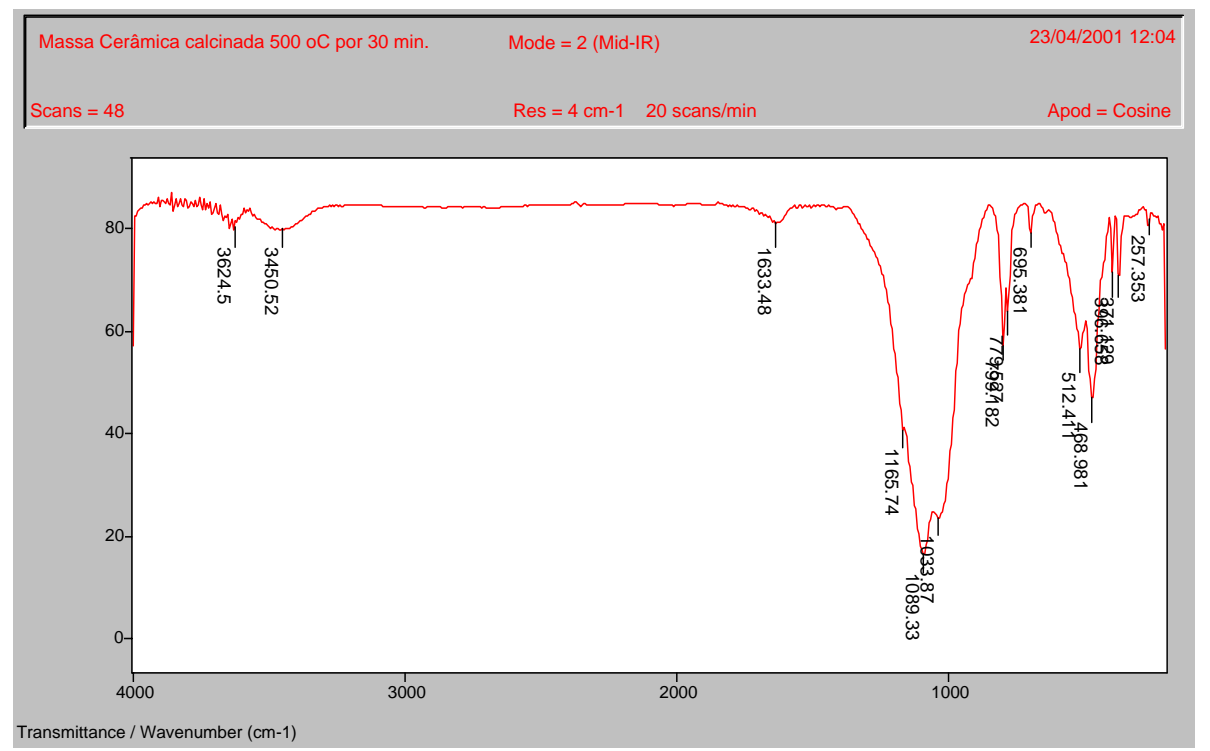

Figura 21: Espectro de FTIR de amostra da massa cerâmica seca calcinada em $500^{\circ} \mathrm{C}$ por 30 minutos. 
As bandas características de caolinita deixam de ser observadas, o que indica que a caolinita perde água muito mais facilmente que a ilita. Já nas ilitas, o processo de desidroxilação não ocorre tão rapidamente, pois ainda são observadas algumas bandas. Uma vez que o processo não se completou, ocorre uma situação na qual parte das hidroxilas já saiu e outra parte ainda permanece na estrutura, promovendo um deslocamento e alargamento da região de transmissão, podendo ser observadas as bandas na região de $3625 \mathrm{~cm}^{-1}, 3450 \mathrm{~cm}^{-1}$ e $914 \mathrm{~cm}^{-1}$.

A massa cerâmica submetida a tratamento térmico em altas temperaturas, resulta em dois produtos majoritários que são a mulita e o quartzo. A evolução dessas modificações químicas já é percebida na temperatura de $500^{\circ} \mathrm{C}$. Analisando o restante do espectro de IR, encontramos todas as bandas de transmissão características de quartzo.

Sintetizando, o espectro da massa cerâmica calcinada a $500^{\circ} \mathrm{C}$ por 30 minutos apresenta, basicamente, bandas características de ilita, caolinita e quartzo, uma vez que está ocorrendo a desidroxilação de hidróxidos e óxidos hidratados. Os óxidos anidros que surgem dessa desidroxilação, provavelmente, ficam dentro das estruturas das ilitas ou caolinitas, ou não estão em quantidades suficientes para originarem bandas de transmissão.

\subsubsection{Resíduo da ETARI}

Os resíduos de ETARI apresentam espectro de IR muito similar ao da massa cerâmica, uma vez que são compostos por materiais da massa cerâmicos e resíduos da linha de esmaltação. Entretanto a presença característica de minerais oxihidróxidos é observada pelo aumento da intensidade das bandas ao redor de 3527, 3447 e $1438 \mathrm{~cm}^{-1}$ (Figuras 22, 23 e 24).

A figura 25 apresenta as curvas sobrepostas dos resíduos de ETARI e da massa cerâmica, onde se observam as composições similares, diferindo apenas no conteúdo de espécies hidroxiladas.

Ao ser calcinado em $500^{\circ} \mathrm{C}$ por 30 minutos, a amostra de resíduo de ETARI apresentou um comportamento semelhante ao da massa cerâmica, quanto à 
desidroxilação das espécies, com bandas características do quartzo com menor intensidade, uma vez que está em menor quantidade (Figura 25).

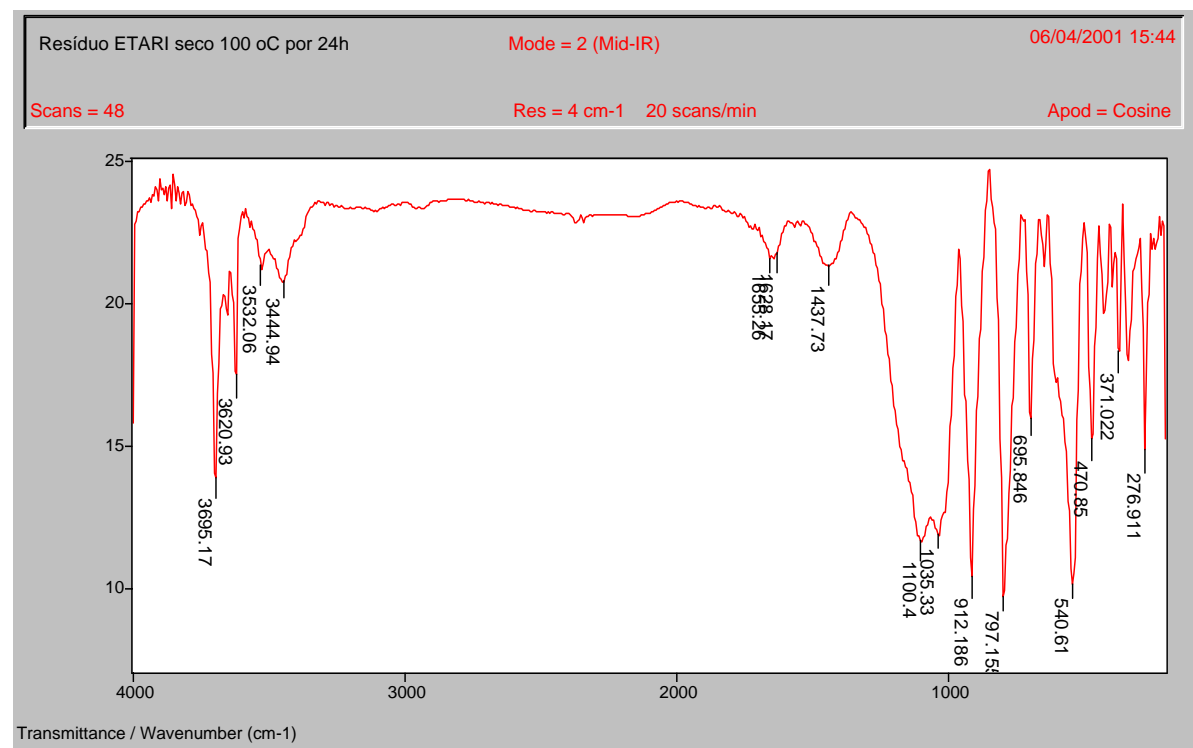

Figura 22: Espectro de FTIR de amostra de resíduo de ETARI seca em estufa a $100^{\circ} \mathrm{C}$ por 24 horas.

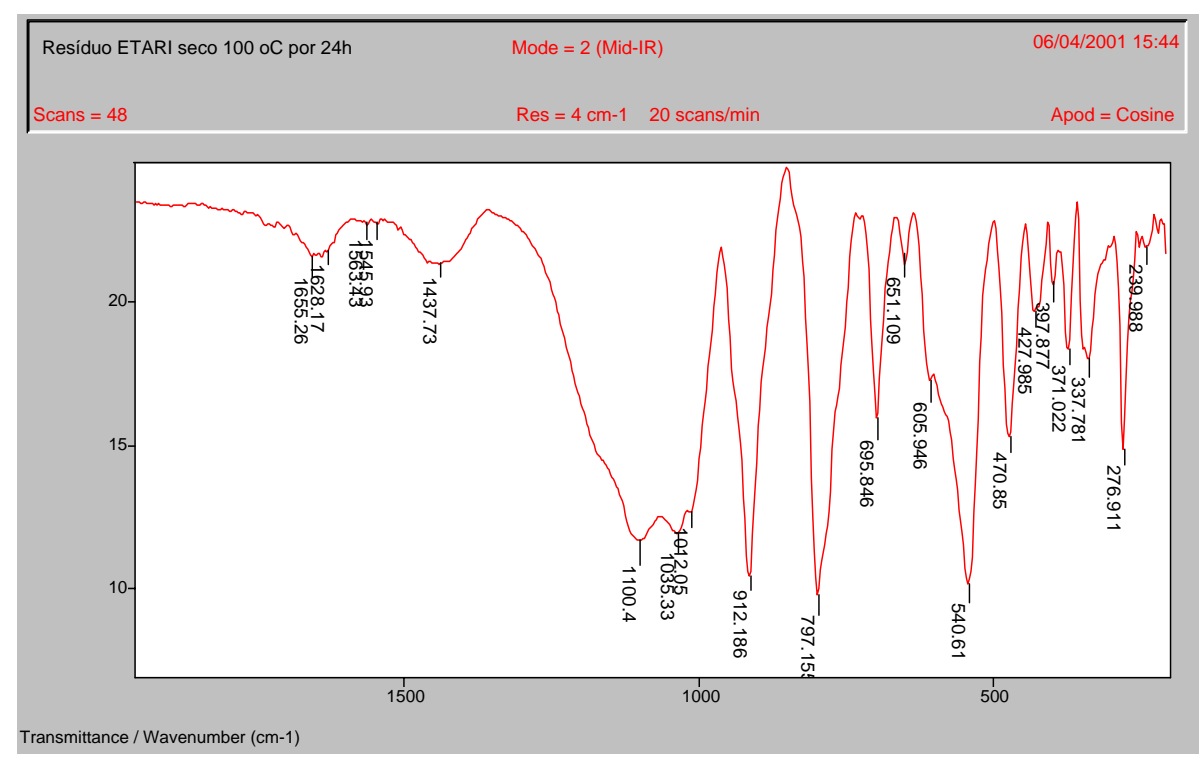

Figura 23: Detalhe da região de freqüência entre $1800 \mathrm{~cm}^{-1}$ e $200 \mathrm{~cm}^{-1}$ do espectro de FTIR de amostra de resíduo de ETARI seca em estufa a $100^{\circ} \mathrm{C}$ por 24 horas. 


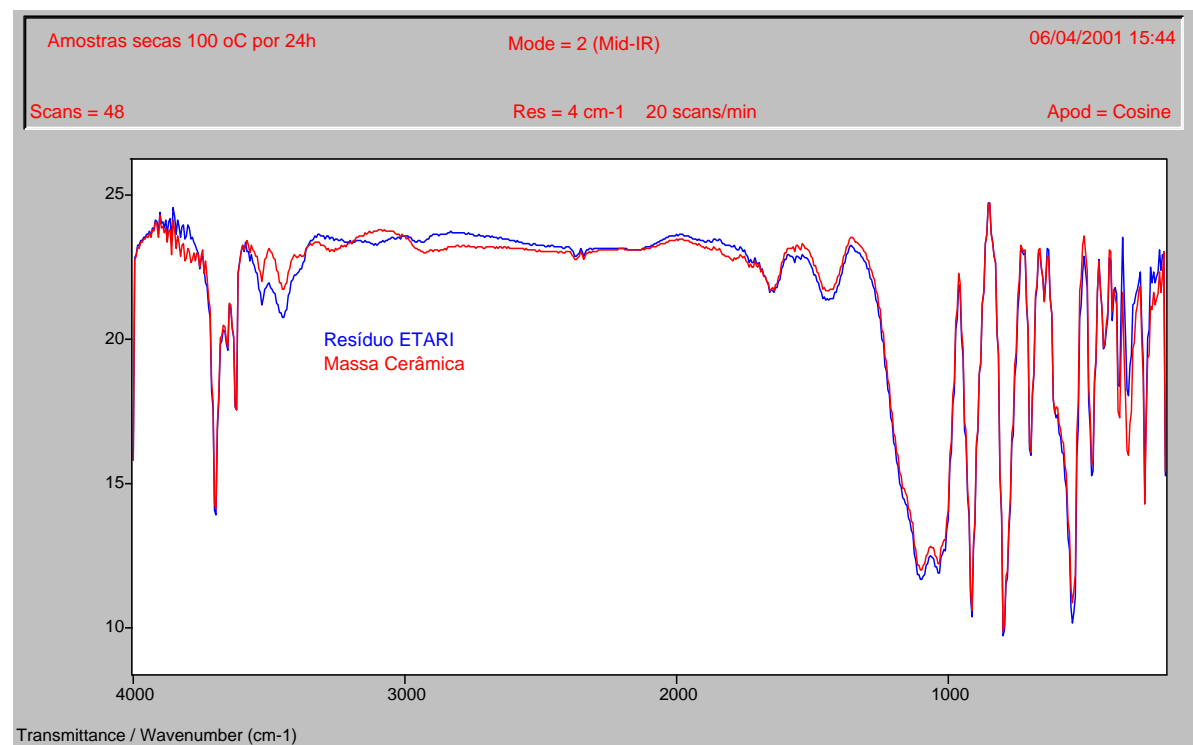

Figura 24: Espectros de FTIR de amostra da massa cerâmica e de resíduo de ETARI, secas em estufa a $100^{\circ} \mathrm{C}$ por 24 horas.

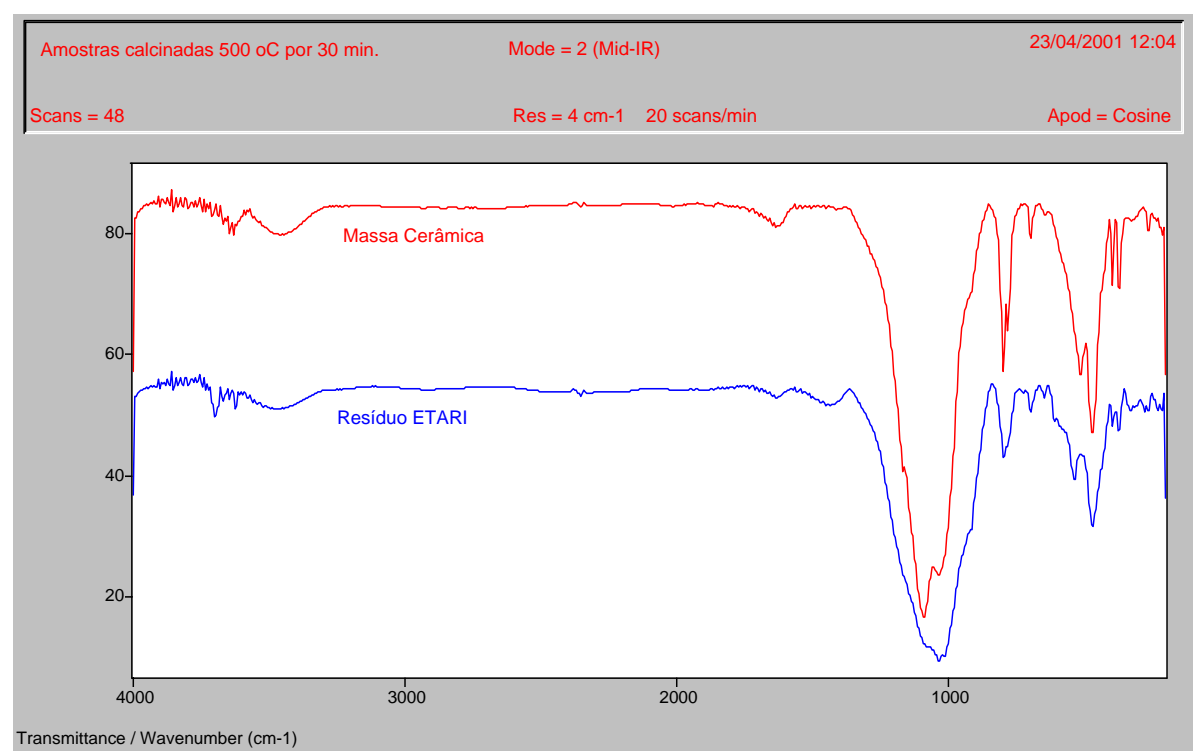

Figura 25: Espectros de FTIR de amostra da massa cerâmica e de resíduo de ETARI, calcinadas em $500^{\circ} \mathrm{C}$ por 30 minutos. 


\subsubsection{Resíduo Queimado.}

A amostra de resíduo queimado apresentou poucas bandas de transmissão em baixa freqüência, indicando que apenas o Quartzo estava presente. Pode-se observar as bandas características de Quartzo, em 800 e $781 \mathrm{~cm}^{-1}$, 516 e $460 \mathrm{~cm}^{-1}$ e 399 e 370 $\mathrm{cm}^{-1}$, além de uma banda simples em $1078 \mathrm{~cm}^{-1}$ e outra em $694 \mathrm{~cm}^{-1}$. Como o resíduo queimado é composto apenas de material da placa cerâmica após sinterização, sendo composto majoritariamente por Quartzo e Mulita e um complexo vítreo, não é observada nenhuma alteração na composição química do resíduo, ao ser submetido à calcinação em $500^{\circ} \mathrm{C}$ por 30 minutos, de acordo com a figura 26.

As bandas relativas à presença de Mulita não foram identificadas no espectro do resíduo queimado, devido à sobreposição de bandas, mas pôde ser identificada por análise de difração de raios-X. A sobreposição das bandas foi verificada, submetendo-se uma amostra de mulita eletrofundida comercial (Elfusa, 99,9\%) a análise de infravermelho, obtendo-se o espectro da figura 27.

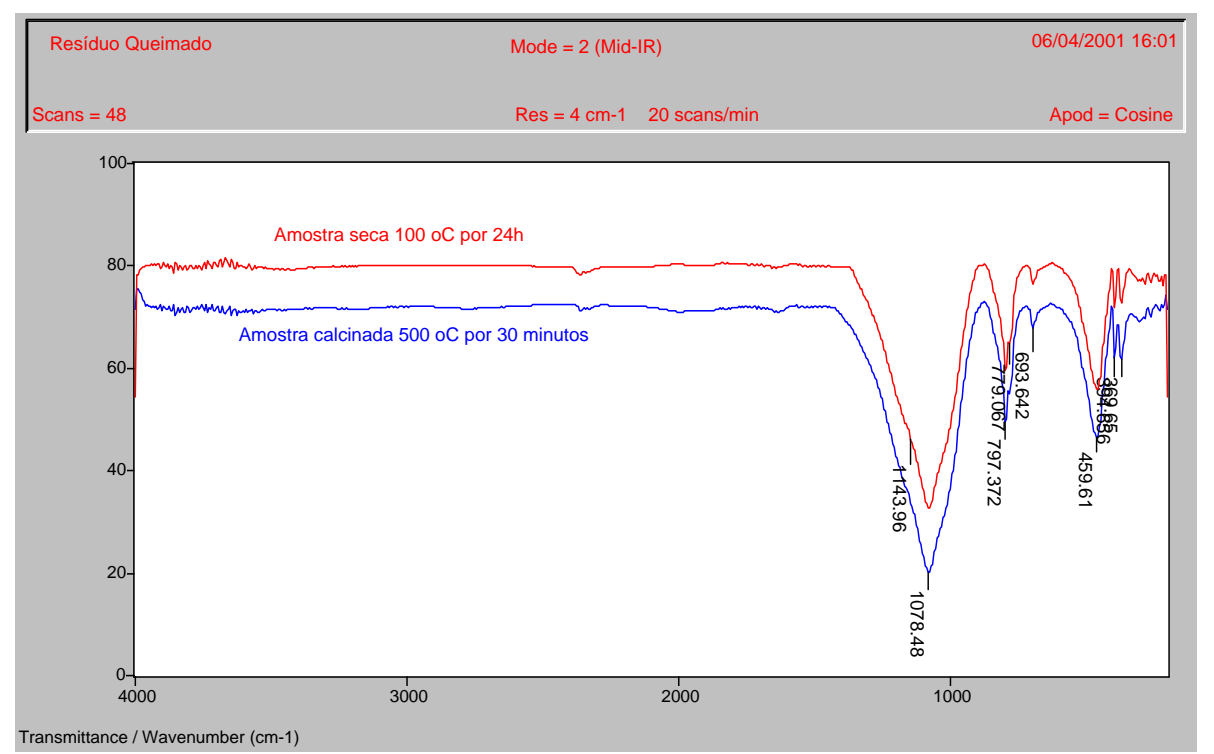

Figura 26: Espectro de FTIR de amostra de resíduo queimado, submetida à secagem em $100^{\circ} \mathrm{C}$ por 24 horas e calcinação em $500^{\circ} \mathrm{C}$ por 30 minutos. 


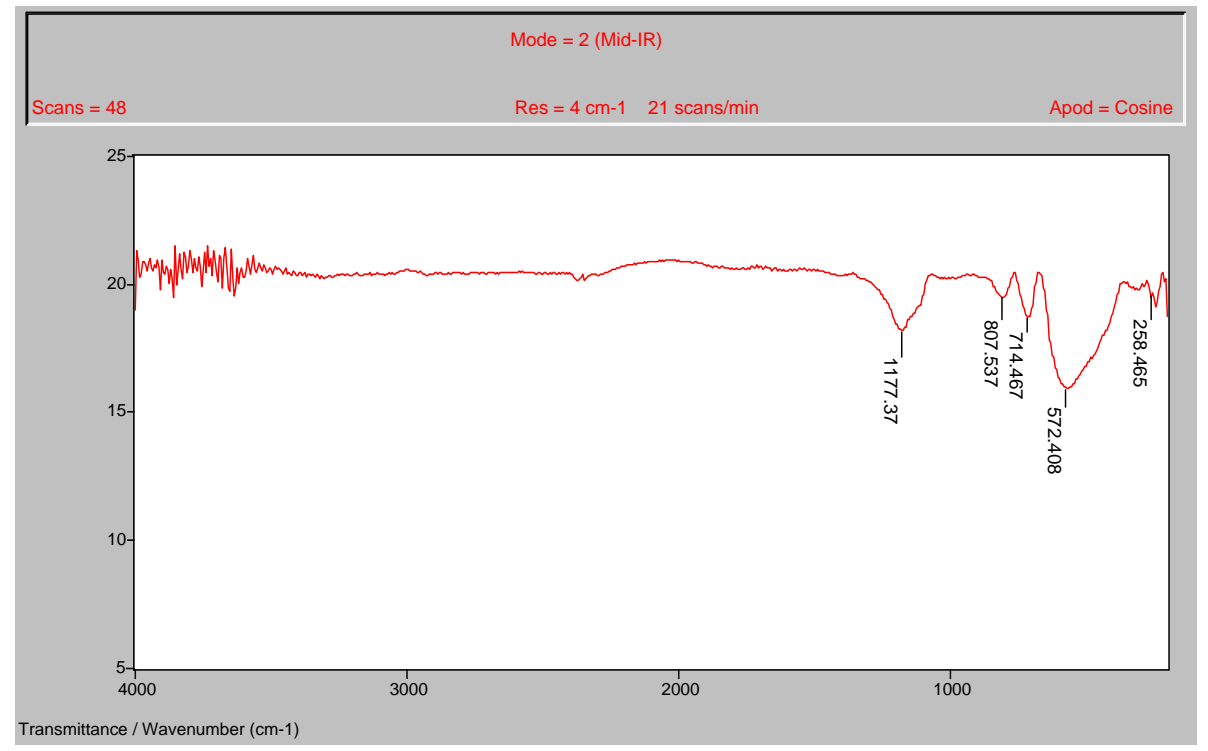

Figura 27 Espectro de FTIR de amostra mulita comercial.

\subsubsection{Análise da composição química}

O conhecimento da composição química das matérias-primas cerâmicas é muito importante, pois influencia diretamente várias propriedades do produto final. O teor de determinados elementos químicos influencia, acentuadamente, as propriedades, recomenda-se conhecer e utilizar essas informações para formular as massas cerâmicas que apresentarão os melhores produtos.

De acordo com FLORÊNCIO (1999, p.37), quanto maior o teor de alumina, maior será a resistência mecânica após queima, pela formação de mulita, e a temperatura de fusão. “Os óxidos de sódio e potássio são fundentes muito ativos que auxiliam o processo de densificação, por outro lado causam o aumento da dilatação por umidade das peças queimadas, uma vez que os vidros por eles formados são muito solúveis em água, originando espaços vazios pela perda dos cátions $\mathrm{Na}^{+}$e $\mathrm{K}^{+}$, com aumento da permeabilidade”.

Os resultados das análises de EDX das amostras da massa e dos resíduos são apresentados na Tabela 10. 
Tabela 10: Análises de EDX de amostras cerâmicas

\begin{tabular}{|c|c|c|c|}
\hline Espécie & $\begin{array}{c}\text { Massa cerâmica } \\
\text { (\% peso) }\end{array}$ & $\begin{array}{c}\text { Resíduo ETARI } \\
\text { (\% peso) }\end{array}$ & $\begin{array}{c}\text { Resíduo } \\
\text { Queimado } \\
\text { (\%peso) }\end{array}$ \\
\hline $\mathrm{SiO}_{2}$ & 65,82 & 62,93 & 69,53 \\
\hline $\mathrm{Al}_{2} \mathrm{O}_{3}$ & 14,91 & 24,59 & 16,66 \\
\hline $\mathrm{Fe}_{2} \mathrm{O}_{3}$ & 5,72 & 1,78 & 5,70 \\
\hline $\mathrm{CaO}$ & nd & 2,42 & 0,54 \\
\hline $\mathrm{MgO}$ & nd & 1,58 & 2,53 \\
\hline $\mathrm{PbO}$ & nd & 0,05 & nd \\
\hline $\mathrm{K}_{2} \mathrm{O}$ & 5,30 & 3,59 & nd \\
\hline $\mathrm{Na}_{2} \mathrm{O}$ & 5,30 & nd & 4,59 \\
\hline $\mathrm{Cr}_{2} \mathrm{O}_{3}$ & nd & 0,20 & nd \\
\hline $\mathrm{CuO}$ & 1,32 & nd & nd \\
\hline $\mathrm{ZnO}$ & 0,62 & 1,72 & nd \\
\hline $\mathrm{MnO}$ & 0,55 & nd & 0,46 \\
\hline $\mathrm{NiO}$ & 0,45 & 1,13 & nd \\
\hline $\mathrm{Perda} \mathrm{massa}$ & $7,1 \%$ & $8,6 \%$ & nd \\
\hline $1000{ }^{\circ} \mathrm{C}$ & & & \\
\hline
\end{tabular}

nd: não determinado.

Os resultados das análises são as médias das medidas pontuais das amostras, portanto os elementos que não foram detectados podem não estar em quantidades possíveis de detecção. Deve ser observado, também, que a determinação de composição química utilizando a técnica de EDX é uma determinação semiquantitativa, usada para estimar uma possível composição, o que torna seus resultados apenas uma estimativa da composição. As quantidades de elementos de formação dos esmaltes, presentes nas lamas, estão dentro do limite estabelecido pelo ITC, para uma composição típica de massa cerâmica da região de Castellón, na Espanha. Observa-se que os teores de $\mathrm{SiO}_{2}$, e óxidos alcalinos apresentaram um pequeno aumento, característico da argila ilítica, mais fundente devido aos teores de sódio e potássio, da região de Santa Gertrudes.

É preciso notar que, ao adicionar os resíduos de ETARI à massa cerâmica, são aumentados, significativamente, os teores de alumina, cálcio, magnésio e potássio, que interferem nas características dos produtos, além dos óxidos dos elementos como cromo, zinco, níquel e chumbo, que influenciam as reações de nucleação da mulita. Quando se adicionam os resíduos queimados, aumentam-se os teores de sílica, alumina, bem como os óxidos de ferro, magnésio e sódio, que 
representam um aumento nas espécies refratárias dentro da massa cerâmica, originando, principalmente, alterações nos ciclos de queima das peças.

\subsubsection{Análises Térmicas.}

As análises de DRX e FTIR mostraram que a massa cerâmica é composta basicamente de uma mistura de argilas ilítica e caolinítica. Esses resultados são confirmados através de análises térmicas, onde o termograma apresenta picos em temperaturas intermediárias que caracterizam a mistura das argilas. As figuras 28 e 29 apresentam as curvas de ATD da massa cerâmica padrão e do resíduo de ETARI, respectivamente.

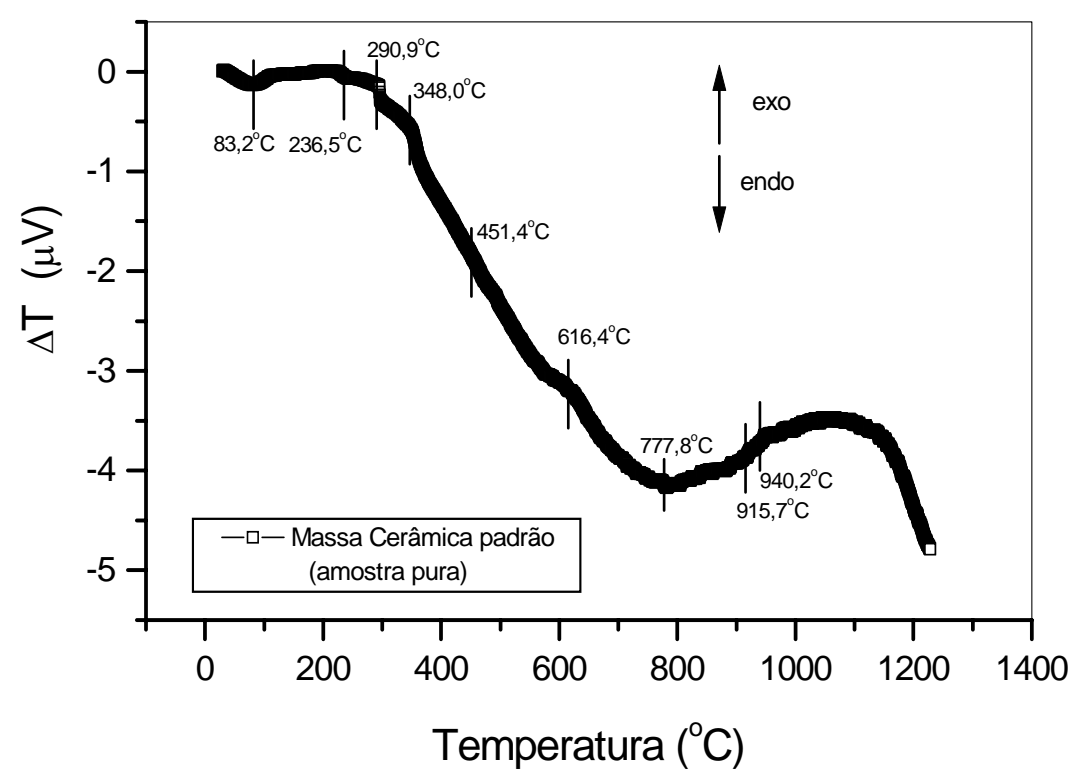

Figura 28: Análise térmica diferencial da massa cerâmica padrão.

As argilas ilíticas apresentam picos característicos entre $100^{\circ} \mathrm{C}-200^{\circ} \mathrm{C}$, devido à saída de água de intercalação das camadas. Entre $450^{\circ} \mathrm{C}$ e $600^{\circ} \mathrm{C}$, existe um pico endotérmico pequeno de perda de água de hidroxilas, que não destrói a estrutura 
cristalina das ilitas dioctaédricas, cujo pico endotérmico é agudo, apresentando uma banda nas ilitas trioctaédricas.

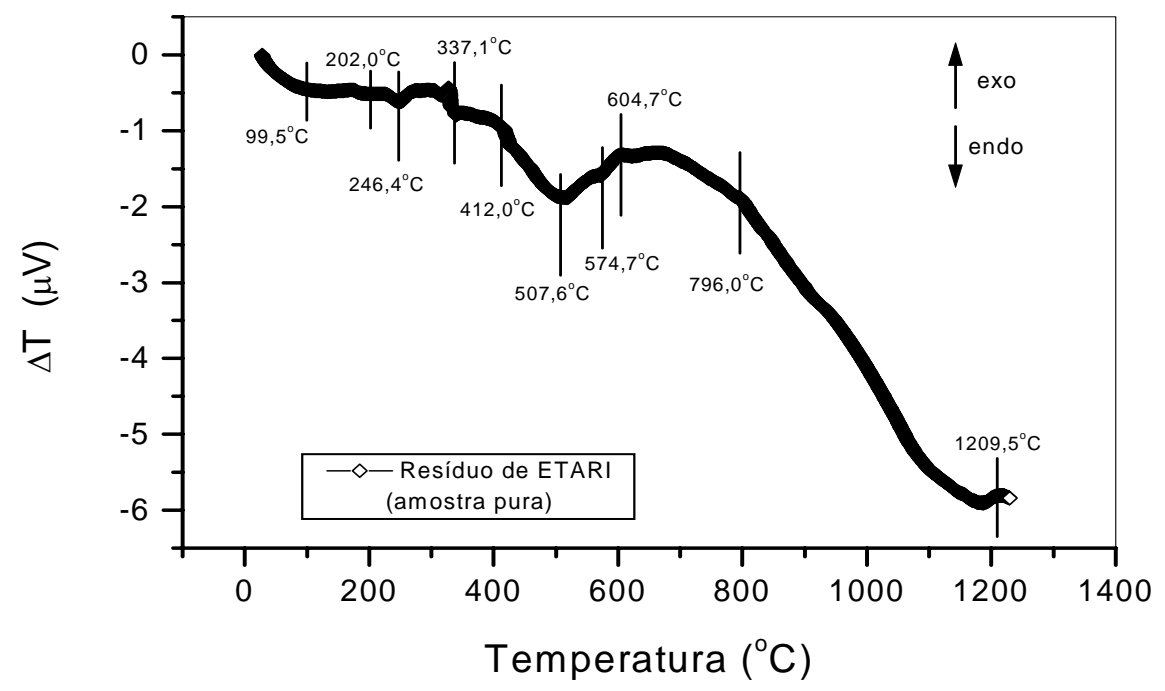

Figura 29: Análise térmica diferencial do resíduo da ETARI.

A caolinita apresenta picos em $450^{\circ} \mathrm{C}-550^{\circ} \mathrm{C}$, onde se inicia a reação de desidroxilação, que se completa em $600^{\circ} \mathrm{C}$ (pico endotérmico). Nessas condições forma-se a metacaulinita, que é amorfa à difração de raios-X, mas que mantém a forma de placas hexagonais da caulinita original; com a perda de hidroxilas há apenas uma diminuição de cristalinidade com pequena distorção dos íons alumínio na camada octaédrica.. Acima de $600^{\circ} \mathrm{C}$, ocorre uma pequena expansão devido aos gases oriundos da oxidação do material orgânico, cuja reação é exotérmica. Allaway apud GRIMM (1953), estudou essa oxidação, determinando que um pico em $700^{\circ} \mathrm{C}$ sugere a presença de ilita rica em magnésio, um pico entre 450 e $500^{\circ} \mathrm{C}$ sugere ilita rica em ferro e um pico ao redor de $600^{\circ} \mathrm{C}$ sugere uma ilita contendo um pouco de alumínio em coordenação tetraedral, mas esses picos são de intensidade relativamente fraca, de acordo com a figura 28, cuja ATD apresenta um pico exotérmico em $616,4^{\circ} \mathrm{C}$.

Tem-se, entre $915,7^{\circ} \mathrm{C}$ e $940,2^{\circ} \mathrm{C}$, respectivamente, um pico duplo endoexotérmico. O pico endotérmico a $915,7^{\circ} \mathrm{C}$ é devido à perda da estrutura cristalina e o pico exotérmico a $940,2^{\circ} \mathrm{C}$ é devido a formação de espinélio; quando a caolinita está presente pode-se ter a formação de mulita nessas temperaturas. De acordo com 
SANTOS (1966), existe a possibilidade de que nessa temperatura, ocorra a nucleação de cristais de mulita pela transformação de unidades octaédricas distorcidas nas faces para unidades octaédricas distorcidas nas arestas, assim, a formação de mulita seria um processo em etapas que teria lugar na direção perpendicular aos planos basais da caulinita, portanto a formação de mulita é mais fácil nas caulinitas bem cristalizadas devido à melhor organização na direção do eixo c. Para FLORÊNCIO (1999), nas massas cerâmicas, os metais alcalinos retardam a formação de mulita. Ferro, boro e titânio facilitam a formação de mulita e, portanto, esta se forma em temperaturas mais baixas e em maiores quantidades. Desse modo, pode-se prever que a massa cerâmica padrão em estudo poderá resultar em peças queimadas de resistência mecânica elevada, uma vez que a mulita se forma mais facilmente a partir da caolinita, ajudada pela ilita, que contém bastante ferro.

O tipo de caulinita influi na natureza da mulita formada, isto é, se é em agulhas grandes ou pequenas. A reação que ocorre é descrita em (7).

$$
3\left(\mathrm{Al}_{2} \mathrm{O}_{3} \cdot 2 \mathrm{SiO}_{2}\right) \rightarrow 3 \mathrm{Al}_{2} \mathrm{O}_{3} \cdot 2 \mathrm{SiO}_{2}+4 \mathrm{SiO}_{2}
$$

Os primeiros traços de líquido nas argilas ilíticas ocorrem ao redor de $1050^{\circ} \mathrm{C}$ e a sua quantidade formada aumenta até que desapareçam todas as fases cristalinas, por volta de $1450^{\circ} \mathrm{C}$. A partir do início da formação da fase líquida, as três fases cristalinas iniciais se dissolvem no líquido e reagem com a sílica para formar a mulita. A quantidade de mulita vai aumentando até $1200^{\circ} \mathrm{C}$, quando começa a se dissolver no líquido.

O começo da fusão é por volta de $1050^{\circ} \mathrm{C}$ e a formação da mulita explica porque muitos produtos cerâmicos, fabricados a partir de argilas predominantemente ilíticas, sinterizam entre $1050^{\circ} \mathrm{C}$ e $1130^{\circ} \mathrm{C}$. A fase vítrea resultante da fusão é proporcional ao produto com baixa porosidade e a presença de mulita promove resistência e durabilidade. A tabela 11 resume as informações sobre o comportamento térmico da massa cerâmica e do resíduo de ETARI. 
Tabela 11: Picos característicos presentes nos termogramas da massa cerâmica e do resíduo de ETARI.

\begin{tabular}{|c|c|c|c|}
\hline \multicolumn{2}{|c|}{$\begin{array}{l}\text { Temperatura do Pico } \\
\qquad\left({ }^{\circ} \mathrm{C}\right)\end{array}$} & \multirow{2}{*}{$\begin{array}{l}\text { Natureza do } \\
\text { Pico }\end{array}$} & \multirow[t]{2}{*}{ Característica do Pico } \\
\hline $\begin{array}{c}\text { Massa } \\
\text { Cerâmica }\end{array}$ & $\begin{array}{l}\text { Resíduo } \\
\text { ETARi }\end{array}$ & & \\
\hline 83,2 & 99,5 & endotérmico & $\begin{array}{c}\text { Eliminação de água de umidade ou } \\
\text { adsorvida. Temperatura típica de } \\
\text { argila caulinítica }\end{array}$ \\
\hline $236,5-348,0$ & $200,0-337$ & endotérmico & $\begin{array}{c}\text { Típico de desidroxilação } \mathrm{Al}(\mathrm{OH})_{3} \text { do } \\
\text { tipo cliaquita-amorfo }\end{array}$ \\
\hline 415,4 & $412,0-507,6$ & endotérmico & $\begin{array}{c}\text { Desidroxilação em } \\
\text { Forma de banda das ilitas } \\
\text { trioctaédricas }\end{array}$ \\
\hline Não observado & 574 & endotérmico & $\begin{array}{c}\text { Transição } \alpha-\beta \text { Quartzo. } \\
\text { Pouco perceptível nos resíduos } \\
\text { ETARI }\end{array}$ \\
\hline 616,4 & 604,7 & exotérmico & Oxidação matéria orgânica \\
\hline $915,7,0$ & Não observado & endotérmico & $\begin{array}{c}\text { Perda da estrutura cristalina das } \\
\text { caulinitas }\end{array}$ \\
\hline 940,2 & Não observado & exotérmico & $\begin{array}{l}\text { Formação dos espinélios a partir das } \\
\text { ilitas e formação da metacaulinita a } \\
\text { partir da caulinita }\end{array}$ \\
\hline
\end{tabular}

Em alguns materiais, o decréscimo no tamanho de grão pode ser acompanhado pelo decréscimo da cristalinidade, o qual é refletido em uma curva de ATD de menor intensidade de reação e um decréscimo nas temperaturas dos picos de reação. Esse comportamento é observado para as amostras de resíduo fração 1 e 2, uma vez que a fração 2 possui granulometria menor que a fração 1 . As curvas de ATD dos resíduos queimados frações 1 e 2 são apresentados na figura 30, onde se 
observa a natureza refratária do material, apresentando apenas alguns picos referentes a transformação de fases.

Através das análises de DRX e FTIR foi constatado que os resíduos queimados são compostos de quartzo, mulita e um complexo vítreo, contendo alofano. Uma vez que são conhecidos os comportamentos térmicos do quartzo e da mulita, os picos observados na região de 500, 600 e $700^{\circ} \mathrm{C}$ são atribuídos à presença do complexo vítreo.

Em baixas temperaturas a deflexão da curva é devida a uma perda de água muito lenta e gradual; próximo a $500^{\circ} \mathrm{C}$ ocorre uma pequena flexão endotérmica, que Nutting apud GRIM (1953) relaciona com a perda de água estrutural do alofano, o que reflete em alguma organização do alofano ou na possível presença de material cristalino. Essa flexão ocorre em $564,8^{\circ} \mathrm{C}$ e $544,8^{\circ} \mathrm{C}$, nas amostras de resíduo queimado fração 1e 2, respectivamente.

Na temperatura de $933,8^{\circ} \mathrm{C}$ pode ser observado um pico exotérmico alargado e pouco intenso, na amostra do resíduo fração 1, que é associado à uma nova nucleação de mulita a partir do material que não conseguiu formar os núcleos durante a primeira queima da peça. Na amostra de resíduo fração 2 esse pico ocorre em $891,2^{\circ} \mathrm{C}$.

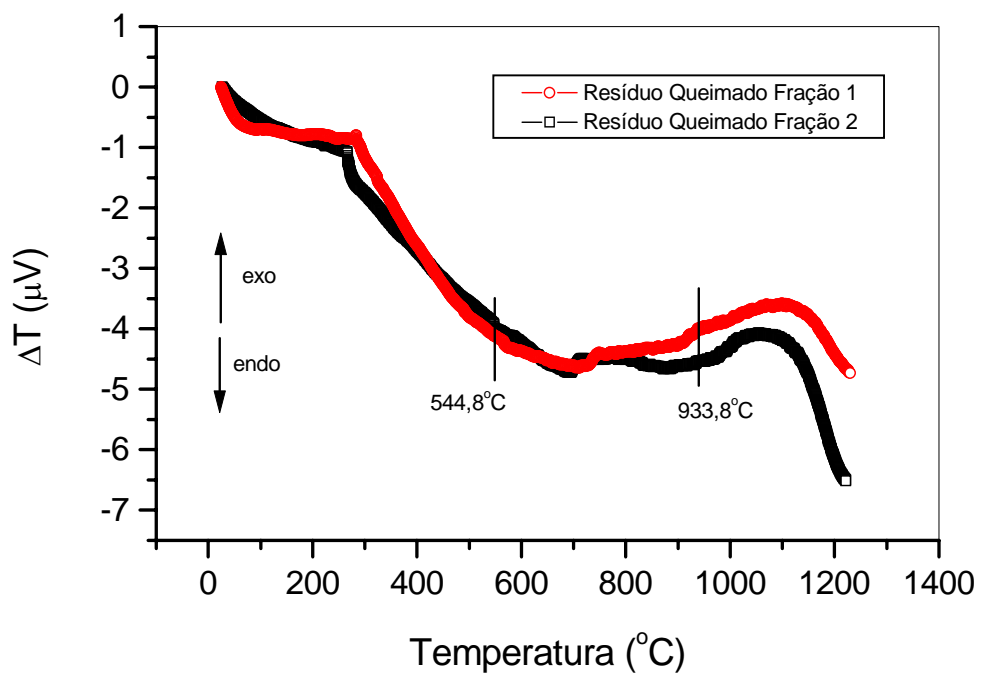

Figura 30: Análise térmica diferencial dos resíduos queimados frações 1 e 2. 


\subsubsection{Análise Granulométrica.}

Conhecer e controlar os parâmetros de processamento cerâmico é fundamental para a obtenção do produto com a qualidade desejada. Ao se falar em peças sinterizadas, um parâmetro muito importante é a granulometria das matériasprimas. A distribuição granulométrica influencia a densidade aparente, a porosidade, a absorção de água e outros fatores como a cinética de reações de formação e extinção de fases durante a sinterização das peças cerâmicas.

A figura 31 apresenta as curvas granulométricas dos resíduos da ETARI e queimado fração 1 e 2, bem como a da massa cerâmica.

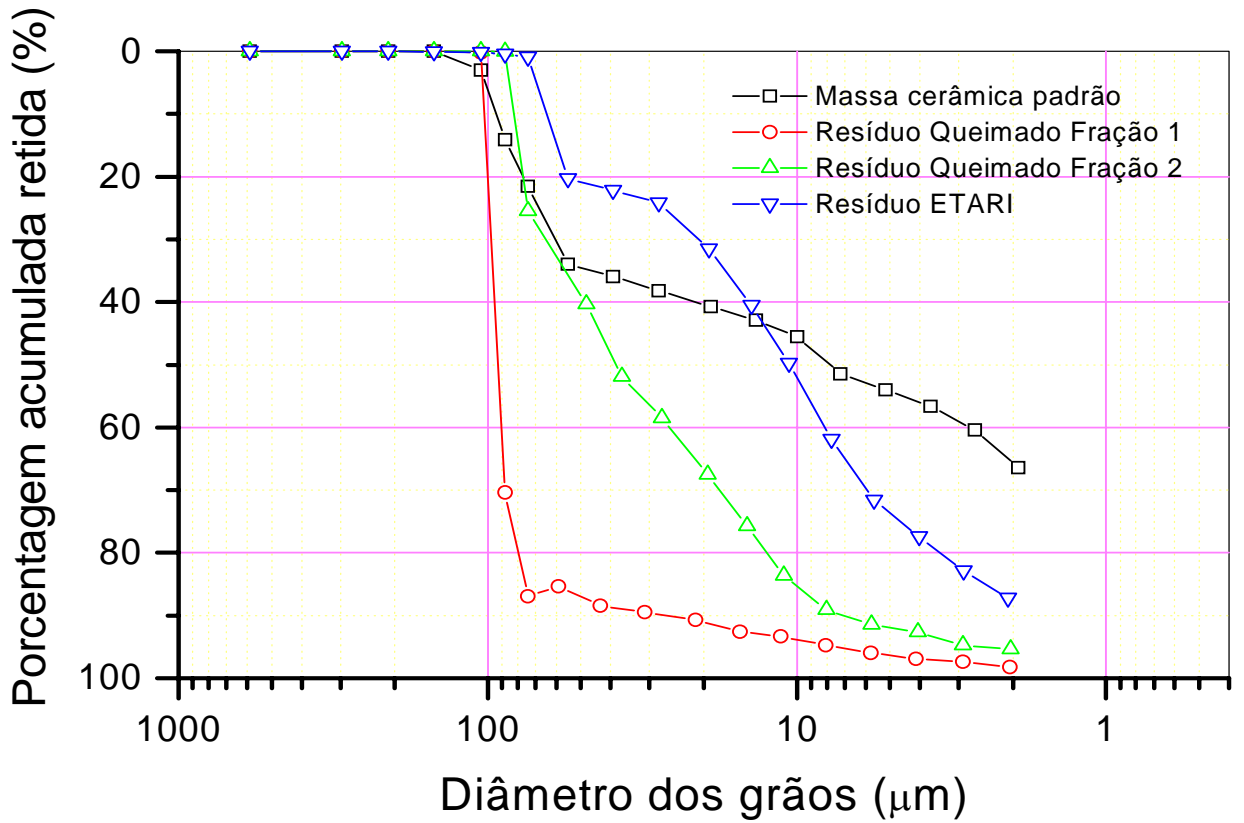

Figura 31: Porcentagem acumulada de grãos retidos versus o diâmetro esférico equivalente $(\mu \mathrm{m})$, das amostras de resíduo da massa cerâmica padrão e dos resíduos de ETARI e queimado frações 1 e 2 . 
Na amostra da massa cerâmica, cerca de 55\% dos grãos têm diâmetro esférico menor que $10 \mu \mathrm{m}$, o que concorda com os dados da literatura sobre a distribuição granulométrica de uma massa cerâmica típica (BARBA et al., 1997). A amostra do resíduo cerâmico queimado fração 2, como é esperado, uma vez que já foi submetida a aquecimento, tendo conseqüentemente, ocorrido crescimento de grãos, apresenta uma fração menor de grãos pequenos, cerca de $14 \%$ abaixo de $10 \mu \mathrm{m}$ e, uma larga distribuição de tamanho de grãos entre $10 \mu \mathrm{m}$ e $50 \mu \mathrm{m}$, correspondendo a $43 \%$. A amostra de resíduo queimado fração 1, que é constituída pelo material passante na peneira malha 0,30mm, apresenta uma estreita distribuição de tamanhos de grãos, sendo que aproximadamente $12 \%$ da amostra possui tamanho médio de grão menor que $50 \mu \mathrm{m}$, e apenas 3, 67\% tem tamanho de grãos menor que $5 \mu \mathrm{m}$. Na amostra do resíduo da ETARI, observa-se uma quantidade menor de grãos com diâmetro inferior a $10 \mu \mathrm{m}$, cerca de $50 \%$, porém ela apresenta uma distribuição granulométrica menos ampla do que a massa cerâmica, na qual cerca de 27\% dos grãos têm diâmetro entre $10 \mu \mathrm{m}$ e $30 \mu \mathrm{m}$, a tabela 12 ilustra melhor esses dados extraídos do gráfico de distribuição granulométrica.

Tabela 12: Distribuição granulométrica das amostras de massa cerâmica e resíduos da ETARI e queimados.

\begin{tabular}{|c|c|c|c|c|}
\hline Amostra & $\begin{array}{c}\text { Granulometria } \\
<50 \mu \mathrm{m}\end{array}$ & $\begin{array}{c}\text { Granulometria } \\
<30 \mu \mathrm{m}\end{array}$ & $\begin{array}{c}\text { Granulometria } \\
<10 \mu \mathrm{m}\end{array}$ & $\begin{array}{c}\text { Granulometria } \\
<5 \mu \mathrm{m}\end{array}$ \\
\hline Massa cerâmica & $64,91 \%$ & $61,81 \%$ & $54,47 \%$ & $45,16 \%$ \\
\hline Resíduo ETARI & $78,36 \%$ & $76,11 \%$ & $47,88 \%$ & $26,62 \%$ \\
\hline $\begin{array}{c}\text { Resíduo } \\
\text { Queimado Fração } \\
1\end{array}$ & $12,14 \%$ & $10,26 \%$ & $6,02 \%$ & $3,67 \%$ \\
\hline $\begin{array}{c}\text { Resíduo } \\
\text { Queimado Fração } \\
2\end{array}$ & $61,43 \%$ & $43,18 \%$ & $13,74 \%$ & $7,90 \%$ \\
\hline
\end{tabular}




\subsubsection{Determinação Da Área Superficial Específica.}

A amostra da massa cerâmica apresentou uma área específica de $30 \mathrm{~m}^{2} / \mathrm{g}$, situando-se no intervalo de 50 a $100 \mathrm{~m}^{2} / \mathrm{g}$ característico das argilas predominantemente ilíticas. Os resíduos de ETARI apresentaram uma área específica de $10 \mathrm{~m}^{2} / \mathrm{g}$ e os resíduos queimados frações 1 e 2 apresentaram valores abaixo do limite de detecção do aparelho, menores que $5 \mathrm{~m}^{2} / \mathrm{g}$.

\subsubsection{Análise Toxicológica - Lixiviação}

A classificação dos resíduos quanto à sua toxicidade foi realizada através do método de lixiviação. A tabela 13 apresenta os resultados das análises de absorção atômica das amostras do lixiviado da massa cerâmica e dos resíduos da ETARI e Queimado. Uma vez que as concentrações de chumbo e cromo total no resíduo de ETARI e de cromo total no resíduo Queimado excedem as concentrações máximas permitidas pelas normas regulamentares, estes resíduos foram classificados como Classe I - TÓXICO (TL)

Tabela 13: Análise de lixiviação da massa cerâmica e dos resíduos.

\begin{tabular}{|c|c|c|c|c|}
\hline Elemento & $\begin{array}{c}\text { Massa } \\
\text { Cerâmica }\end{array}$ & Resíduo ETARI & $\begin{array}{c}\text { Resíduo } \\
\text { Queimado }\end{array}$ & $\begin{array}{c}\text { Limite Máx. } \\
\text { (ppm) }\end{array}$ \\
\cline { 2 - 4 } & Lixiviado & Lixiviado & Lixiviado & \\
\cline { 2 - 4 } & $\begin{array}{c}\text { Determ. Exp. } \\
(\mathrm{ppm})\end{array}$ & $\begin{array}{c}\text { Determ. Exp. } \\
(\mathrm{ppm})\end{array}$ & $\begin{array}{c}\text { Determ. Exp. } \\
\text { (ppm) }\end{array}$ & \\
\hline $\mathrm{Zn}$ & $\mathrm{nd}$ & $34,72 \pm 3,86$ & $79,45 \pm 3,85$ & $\mathrm{ni}$ \\
\hline $\begin{array}{c}\mathrm{Pb} \\
\text { (inorg) }\end{array}$ & $\mathrm{nd}$ & $64,80 \pm 3,09$ & $\mathrm{nd}$ & 5,0 \\
\hline $\mathrm{Cd}$ & $\mathrm{nd}$ & $\mathrm{nd}$ & $\mathrm{nd}$ & 0,5 \\
\hline $\mathrm{Mn}$ & $10,80 \pm 3,08$ & $246,0 \pm 7,0$ & $11,57 \pm 0,77$ & $\mathrm{ni}$ \\
\hline $\mathrm{Cu}$ & $\mathrm{nd}$ & $\mathrm{nd}$ & $95,65 \pm 1,55$ & $\mathrm{ni}$ \\
\hline $\mathrm{Ni}$ & $\mathrm{nd}$ & $5,40 \pm 0,77$ & $12,34 \pm 0,00$ & $\mathrm{ni}$ \\
\hline $\begin{array}{c}\mathrm{Cr} \\
(t o t a l)\end{array}$ & $1,54 \pm 0,00$ & $6,07 \pm 0,00$ & $6,17 \pm 0,00$ & 5,0 \\
\hline
\end{tabular}

ni: não informado pela norma NBR 10005

nd: não detectado 
O resíduo de ETARI foi classificado como tóxico devido às concentrações de chumbo e cromo excederem as concentrações máximas permitidas pela norma NBR 10005. Esse procedimento normalizado para a classificação de resíduos é baseado na simulação de descarte do resíduo em aterro sanitário comum, cujo potencial hidrogeniônico $(\mathrm{pH})$ é baixo, ou seja, o meio é ácido e os resíduos sofrem a ação da lixiviação por água das chuvas e dos próprios resíduos.

A constatação da presença de chumbo na lama da ETARI levantou uma questão sobre sua fonte, uma vez que as indústrias de placas cerâmicas deixaram de utilizar fritas e esmaltes contendo chumbo já faz algum tempo.

Outra consideração é que para se conseguir fazer a lixiviação ácida, é necessário um volume considerável de ácido diluído, pois o pH do resíduo de ETARI é bastante alto, ou seja, o resíduo tem caráter muito básico, o que dificulta a lixiviação de seus elementos. Desse modo, supondo que esse resíduo fosse descartado em aterro sanitário comum, o que se pode dizer é que seria necessário um tempo maior para o início do processo de lixiviação natural, mas não significa que a lixiviação deixaria de ocorrer.

Com relação às concentrações de $\mathrm{Ni}$, Zn e Cu serem maiores nas amostras de resíduo Queimado que no resíduo de ETARI, é preciso considerar que as amostras de resíduo de ETARI representam uma média (porção homogeneizada) de todo o resíduo do tanque de decantação, o que produz certo efeito de diluição sobre os constituintes, ao passo que para constituir as amostras de resíduo Queimado, foram escolhidas, ao acaso, peças fora de especificações, que, por ventura, devido à sua decoração, podem apresentar uma maior quantidade de determinados elementos. O resíduo Queimado geralmente é declarado inerte pelos profissionais de cerâmica, o que se explica neste caso, se levarmos em conta que a concentração do elemento $\mathrm{Cr}$ excede $1,17 \mathrm{ppm}$ do limite permitido e que seu estado de oxidação é o +3 , que apresenta menor perigo de toxicidade, mas para todos os efeitos de ensaios normalizados ele é declarado tóxico.

É necessário e importante salientar que para o ensaio de lixiviação do resíduo queimado, foi utilizada uma granulometria muito fina (fração passante na peneira malha 200), o que propicia a lixiviação de elementos como o cromo, além do 
procedimento do ensaio ser sob condições ácidas. Quanto menor o tamanho de grão do resíduo, maior a área superficial e, portanto, mais fácil de lixiviar os elementos.

Na prática não ocorre uma lixiviação ácida, pois esses resíduos são utilizados para pavimentar estradas vicinais de terra, e as chuvas que caem, por mais ácidas que possam se tornar, não chegam á um $\mathrm{pH}$ suficiente para promover uma lixiviação ácida como foi realizada nos ensaios normalizados. Além disso, os resíduos queimados são descartados como “cacos” de tamanho bem superior ao do resíduo ensaiado pelo teste de lixiviação, o que torna ainda mais difícil esse processo. Essas considerações nos levam a afirmar que, embora os testes apontem a toxicidade dos resíduos queimados, em vias normais de descarte eles não apresentam condições para serem considerados potencialmente resíduos tóxicos.

A tabela 14 apresenta os resultados das análises de absorção atômica das amostras do lixiviado da massa cerâmica contendo 10\% em peso de resíduos da ETARI e Queimado. Uma vez que as concentrações de elementos não excedem as concentrações máximas permitidas pelas normas regulamentares, estes resíduos foram classificados como Classe III - INERTES (TL)

Tabela 14: Análise de lixiviação da massa cerâmica contendo resíduos.

\begin{tabular}{|c|c|c|c|}
\hline Elemento & $\begin{array}{c}\text { Massa Cerâmica c/ } \\
\text { 10\% Res. ETARI }\end{array}$ & $\begin{array}{c}\text { Massa Cerâmica c/ } \\
\text { 10\% Res. Queimado }\end{array}$ & $\begin{array}{c}\text { Limite } \\
\text { Máx. } \\
\text { (ppm) }\end{array}$ \\
\cline { 2 - 3 } & $\begin{array}{c}\text { Extrato } \\
\text { (ppm) }\end{array}$ & $\begin{array}{c}\text { Extrato } \\
\text { (ppm) }\end{array}$ & \\
\hline $\mathrm{Zn}$ & $3,086 \pm 0,03$ & $5,863 \pm 0,04$ & ni \\
\hline $\begin{array}{c}\mathrm{Pb} \\
\text { (inorg) }\end{array}$ & nd & nd & 5,0 \\
\hline $\mathrm{Cd}$ & $\mathrm{nd}$ & $\mathrm{nd}$ & 0,5 \\
\hline $\mathrm{Mn}$ & $7,71 \pm 0,21$ & $7,91 \pm 0,09$ & ni \\
\hline $\mathrm{Cu}$ & $\mathrm{nd}$ & $8,74 \pm 0,00$ & $\mathrm{ni}$ \\
\hline $\mathrm{Ni}$ & $\mathrm{nd}$ & $\mathrm{nd}$ & $\mathrm{ni}$ \\
\hline $\begin{array}{c}\mathrm{Cr} \\
\text { (total) }\end{array}$ & $1,23 \pm 0,00$ & $2,15 \pm 0,00$ & 5,0 \\
\hline
\end{tabular}

ni: não informado pela norma NBR 10005

nd: não detectado pelo equipamento 
Esses resultados mostram que os resíduos podem ser inertizados por adição à massa cerâmica, fazendo com que a própria empresa geradora do resíduo se torne um vertedouro, promovendo uma produção limpa, através da reutilização dos resíduos no próprio processo de produção.

Entretanto, é preciso ressaltar que existe uma possibilidade (que não foi avaliada nesse trabalho) do chumbo contido no resíduo de ETARI ter volatilizado durante a operação de queima das amostras, nesse caso a reciclagem não estaria sendo eficaz na inertização do chumbo, mas é perfeitamente eficaz na inertização de outros elementos que não volatilizam nas temperaturas de trabalho, como o CROMO, que foi perfeitamente inertizado. A possibilidade de não inertização do chumbo não tira o mérito da prática da reciclagem, uma vez que ele não deve estar presente como uma das matérias-primas.

\subsubsection{Análise Toxicológica - Bioteste}

Os testes de toxicidade aguda são utilizados para se avaliar a concentração de um composto químico ou de uma amostra ambiental que causa um efeito adverso para um determinado grupo de organismo durante um curto período de exposição, sob condições controladas.

De acordo com os resultados obtidos, as amostras BIOT 1R, BIOT 2R, BIOT 3R e BIOT 4R apresentaram toxicidade aguda para o organismo-teste Daphnia similis (um crustáceo). Embora o ácido acético utilizado no processo de lixiviação tenha apresentado toxicidade ao organismo-teste, com $\mathrm{CE}_{50}-48 \mathrm{~h}$ de $0,14 \%$, as concentrações de ácido acético presente nas concentrações de efeitos das amostras BIOT 1R, BIOT 2R, BIOT 3R e BIOT 4R são menores que a $\mathrm{CE}_{50}$ do ácido acético. Os resultados estão apresentados na tabela 15. 
Tabela 15: Teste de toxicidade das amostras BIOT 1R, BIOT 2R, BIOT 3R e BIOT 4R para Daphnia similis (Cladocera).

\begin{tabular}{|c|c|c|c|c|c|c|}
\hline Amostra & $\begin{array}{c}\mathrm{CE}_{50-48 h} \\
(\%)\end{array}$ & $\begin{array}{c}\mathrm{CE}_{50}-48 \mathrm{~h} \\
(\mathrm{mg} / \mathrm{L})\end{array}$ & $\begin{array}{c}\text { Ac. Acético } \\
\text { na amostra } \\
\text { pura }\end{array}$ & $\begin{array}{c}\text { Ac. Acético } \\
\text { na } \begin{array}{c}\text { concentração } \\
\text { de efeito }\end{array}\end{array}$ & \multicolumn{2}{|c|}{ Variáveis finais } \\
\cline { 5 - 7 } & & - & - & - & 7,6 & $\mathrm{OD}$ \\
\hline Controle & - & 5,0 & 0,07 & 8,16 & 7,4 \\
\hline BIOT 1R & 1,4 & 875,0 & 0,28 & 0,0092 & 7,86 & 7,8 \\
\hline BIOT 2R & 3,28 & 2375,0 & 0,18 & 0,0127 & 7,6 & 7,5 \\
\hline BIOT 3R & 10,6 & 5062,5 & 0,18 & 0,014 & 7,08 & 7,4 \\
\hline BIOT 4R & 8,1 & 6625,0 & - & - & 6,47 & 7,4 \\
\hline $\begin{array}{c}\text { Ac. Acético } \\
\text { 0,5N }\end{array}$ & 0,14 & - & - & & & \\
\hline
\end{tabular}

OD: demanda de oxigênio.

De acordo com a legislação espanhola (MONFORT e JOSÉ - 1998), para um resíduo ser caracterizado RTP por bioteste com Daphnia similis, deve apresentar uma $\mathrm{CE}_{50}-48 \mathrm{~h}$ menor ou igual a $750 \mathrm{mg} / \mathrm{mL}$. Desse modo, nenhuma das amostras ensaiadas pôde ser considerada RTP, nem mesmo a amostra BIOT 1R, que corresponde ao resíduo de ETARI, potencialmente o mais tóxico entre todos, e que foi declarada RTP classe 1 - TL, de acordo com o método de determinação de toxicidade constante das normas brasileiras.

\subsection{INCORPORAÇÃO DOS RESÍDUOS NA MASSA CERÂMICA}

\subsubsection{A determinação da curva de gresificação da massa cerâmica padrão.}

As curvas de gresificação podem ser utilizadas para se avaliar o tipo de argila presente, uma vez que depende da composição química, apresentando curvas características. Podemos observar na curva de gresificação da massa cerâmica padrão (Figura 32) uma predominância de ilita, com uma menor quantidade de caolinita, confirmando a caracterização dessas duas espécies, já realizada. 


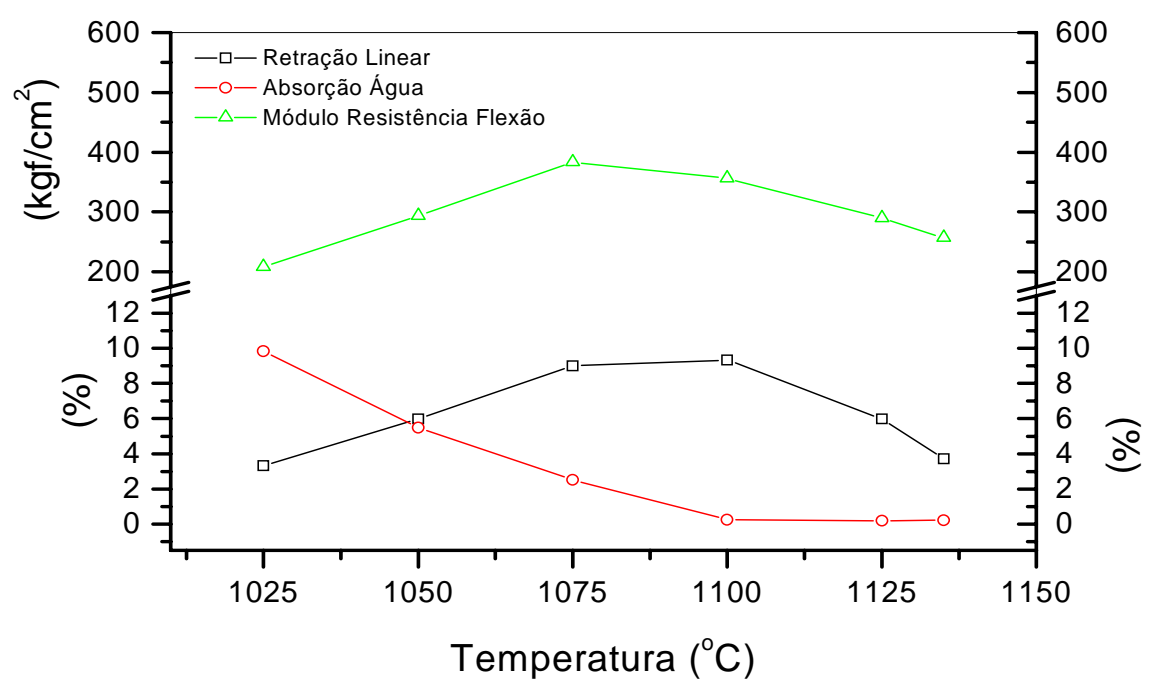

Figura 32: Curva de gresificação da massa cerâmica sem adições de resíduos.

A massa cerâmica padrão apresentou uma temperatura de gresificação de $1048,3^{\circ} \mathrm{C}$, com 5,79\% de retração linear, absorção de água e módulo de resistência à flexão 3 pontos de 287,4 kgf/ $\mathrm{cm}^{2}$ no ponto de gresificação. Esses valores indicam que, no início da gresificação as amostras já possuem a máxima porcentagem de absorção de água e módulo de resistência à flexão superior para a classificação da placa em BIIb, cuja massa é destinada à fabricação de placas com essa classificação.

Ao se observar a Figura 32, a evolução do processo de gresificação da massa cerâmica padrão é característico de mecanismo de sinterização via fase líquida. Nesse mecanismo, em altas temperaturas formam uma fase líquida viscosa, que abaixa a tensão superficial originada pelos pequenos poros da peça e envolvem os grãos do material, facilitando o transporte de material, fazendo os grãos crescerem, diminuindo os espaços vazios, que se reflete em um aumento da retração e diminuição da porosidade da peça.

O aumento da temperatura aumenta a quantidade da fase líquida e a diminuição da sua viscosidade, acelerando o processo de gresificação, até que a absorção de água e a porosidade aberta fiquem praticamente nulas. Observa-se um comportamento muito peculiar da massa cerâmica a partir de $1125^{\circ} \mathrm{C}$, em que a porcentagem de absorção de água apresenta um ligeiro aumento para temperaturas maiores e a retração linear diminui com temperaturas maiores de $1100^{\circ} \mathrm{C}$. 
Conseqüentemente, o módulo de resistência à flexão também apresenta um comportamento parecido.

De acordo com BARBA et al. (1997), esse comportamento é devido a uma expansão dos corpos de prova queimados acima de $1100^{\circ} \mathrm{C}$, causado pela expansão dos gases residuais originados durante a queima da peça.

\subsubsection{Avaliação das propriedades mecânicas de amostras da massa cerâmica contendo resíduo de ETARI.}

Após as queimas e as determinações das porcentagens de absorção de água e retração linear, e módulo de resistência à ruptura, foram obtidas as curvas de gresificação para as misturas contendo as adições do resíduo de ETARI, apresentadas na Figura 33.

Observa-se que, ao aumentar a porcentagem em peso dos resíduos na massa cerâmica, ocorre um deslocamento do ponto de gresificação para temperaturas mais baixas. Esse comportamento é devido à natureza química dos resíduos de ETARI, cujos materiais são de natureza fundente, fazendo com que a massa cerâmica comece a gresificar em temperaturas mais baixas (Figura 34).

Analisando a absorção de água em função da presença de resíduo de ETARI (Figuras 35a e 35b), os resultados evidenciam uma diminuição, em relação à massa cerâmica padrão, para todas as porcentagens de resíduos. Para a temperatura de queima de $1025^{\circ} \mathrm{C}$, porém, essa diminuição é mais pronunciada em porcentagens mais baixas, aumentando a partir de $3 \%$ em peso do resíduo. Isso ocorre provavelmente devido à baixa temperatura de queima, que ainda não atingiu a temperatura do início do processo de gresificação, mas é suficiente para promover a fusão de parte do material constituinte do resíduo. Assim, com a adição de pequenas quantidades de resíduo, é observada uma diminuição da absorção de água pela influência da pequena quantidade de fase líquida, e ao aumentar a quantidade de resíduo, o efeito da granulometria passa a ser maior que o efeito da pequena fase líquida, apresentando um aumento da absorção de água da peça. 

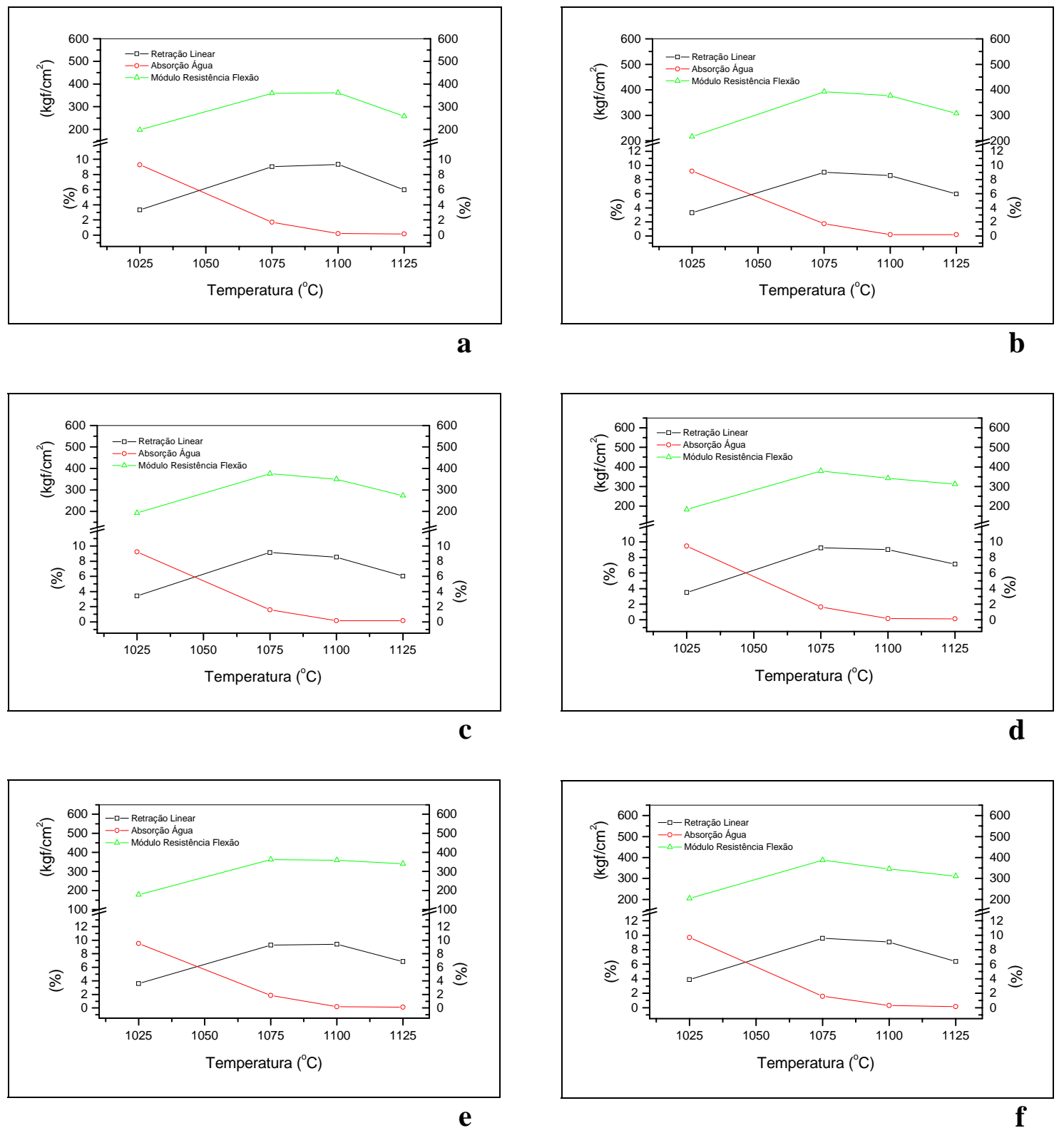

Figura 33: Curvas de gresificação da massa cerâmica contendo adições de resíduo ETARI, (a) 1\% em peso, (b) 2\% em peso, (c) 3\% em peso, (d) 4\% em peso, (e) $5 \%$ em peso e (f) $10 \%$ em peso. 


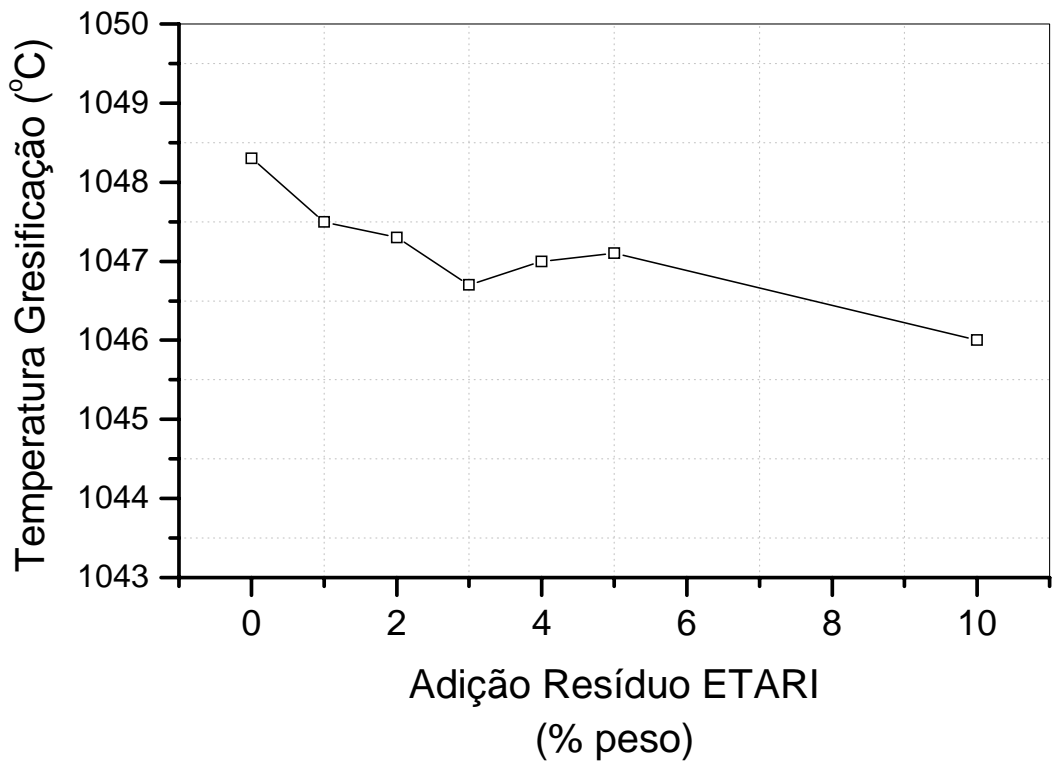

Figura 34: Temperatura do ponto de gresificação, de amostras de massa cerâmica contendo adições em peso de resíduo ETARI.

A granulometria do resíduo influencia a queima do material de maneira muito peculiar. Como já descrito no item 5.1.5, o resíduo de ETARI possui uma porção expressiva de grãos menores, que preenche os espaços vazios entre os grãos maiores da massa cerâmica, resultando em um empacotamento de grãos mais eficiente. Esse efeito tende a um ponto de máxima eficiência e, à medida que se aumenta a quantidade de resíduo, aumenta-se a quantidade de grãos de mesmo tamanho, que prejudica o empacotamento, diminuindo a densidade da peça.

Esse comportamento já não é observado na queima em $1075^{\circ} \mathrm{C}$, em que a massa cerâmica já passou pela temperatura de início de gresificação, fazendo com que a quantidade da fase líquida seja maior e sua viscosidade seja menor; desse modo, o processo de gresificação é favorecido, ficando mais ou menos estável até 5\% de resíduo, diminuindo com a adição 10\% de resíduo. 


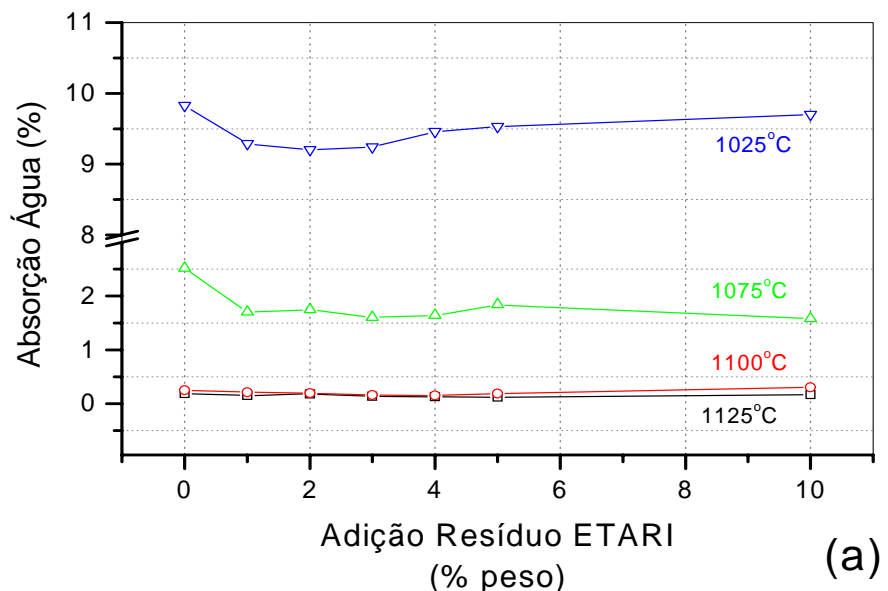

Figura 35-a: Absorção de água de amostras de massa cerâmica contendo adições em peso de resíduo ETARI.

Nas queimas em $1100^{\circ} \mathrm{C}$ e $1125^{\circ} \mathrm{C}$ ocorre um comportamento similar ao da queima em $1025^{\circ} \mathrm{C}$ (Figura 35-b), porém o efeito é devido a grandes quantidades de resíduo, que fundem em temperaturas inferiores, produzindo grande quantidade fase líquida, que podem estar aprisionando os gases residuais da queima, provocando bolhas e, conseqüentemente, uma maior porosidade na peça.

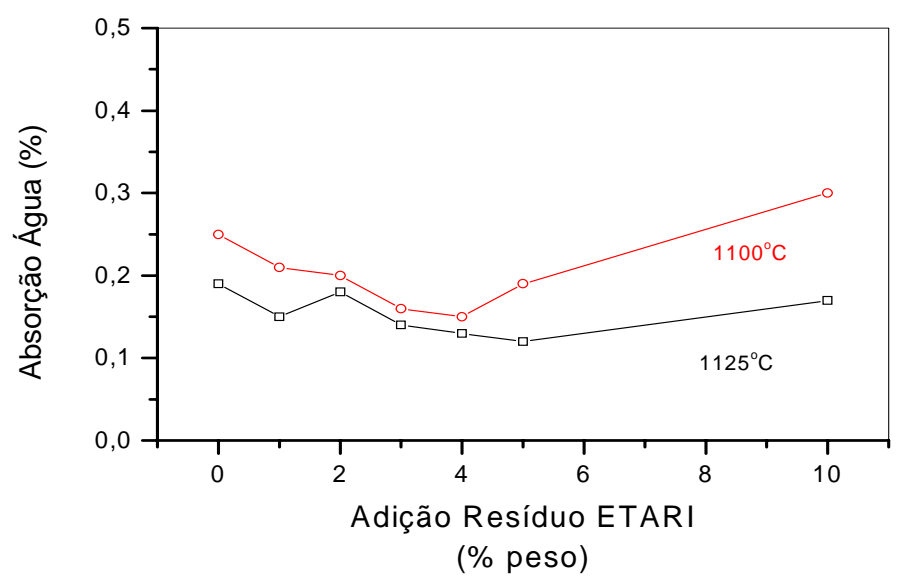

(b)

Figura 35-b: Absorção de água de amostras de massa cerâmica contendo adições em peso de resíduo ETARI. 
Em relação à temperatura de queima, a retração linear das amostras aumenta de $1025^{\circ} \mathrm{C}$ até $1100^{\circ} \mathrm{C}$, devido ao processo de sinterização normal da massa cerâmica e diminui em $1125^{\circ} \mathrm{C}$ devido à expansão provocada pelos gases residuais nas amostras (Figura 36).

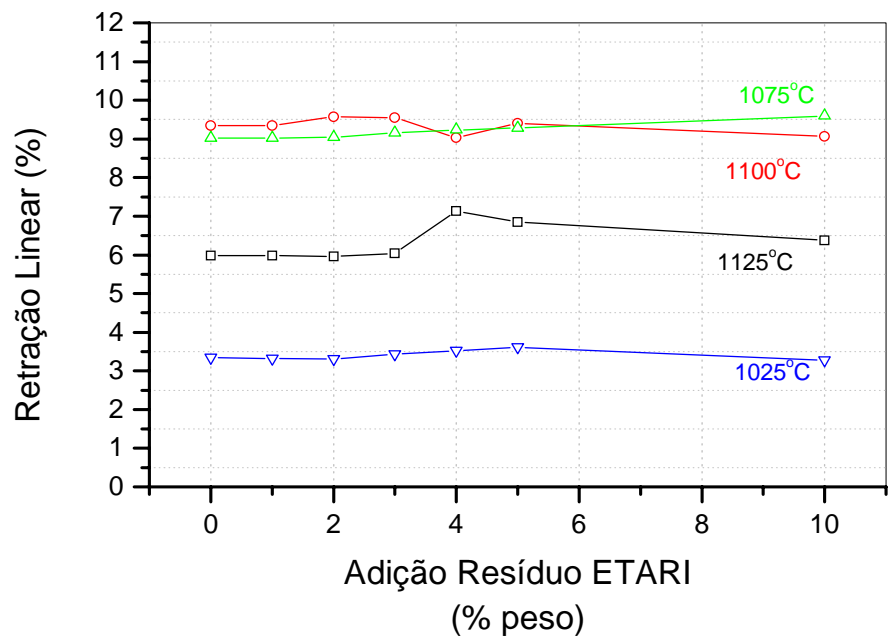

Figura 36: Retração linear de amostras de massa cerâmica contendo adições em peso de resíduo ETARI.

O comportamento da retração linear, em função da adição de resíduo de ETARI, acompanha a discussão já realizada para a absorção de água, isto é, é maior para pequenas adições de resíduo, diminuindo com o aumento da quantidade de resíduo.

A capacidade de absorção de água de uma peça está relacionada à porosidade aparente, assim, esta apresentou comportamento similar àquela, ou seja, quanto maior a porcentagem de poros abertos, maior é a absorção de água (Figura 37). 


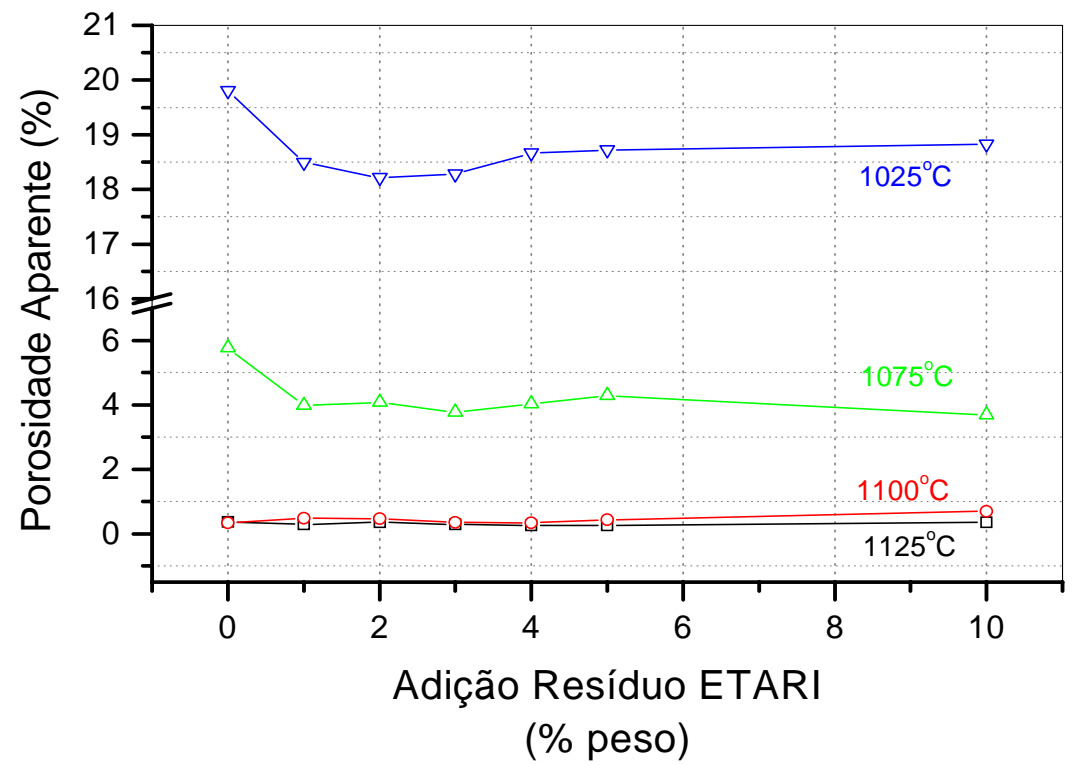

Figura 37: Porosidade aparente de amostras de massa cerâmica contendo adições em peso de resíduo ETARI.

Outra propriedade que pode ser avaliada pela absorção de água e retração linear é a densidade aparente. Quanto maior é a retração linear da peça, mais densa ela fica, e conseqüentemente, menor é a capacidade de absorção de água.

Desse modo, observa-se na Figura 38 o comportamento da densidade aparente queimado, em relação á temperatura de queima. Nesse caso, a densidade aparente aumenta com o aumento da temperatura, de $1025^{\circ} \mathrm{C}$ para $1100^{\circ} \mathrm{C}$, e diminui em $1125^{\circ} \mathrm{C}$, devido à expansão das peças. Quanto á adição de resíduo, a densidade aumenta para pequenas porcentagens, máxima equivalente a $3 \%$ em peso para as temperaturas de $1025^{\circ} \mathrm{C}$ e $1075^{\circ} \mathrm{C}$ e diminui para porcentagens superiores a essas.

Para $1100^{\circ} \mathrm{C}$, a adição de pequenas porcentagens não altera muito a densidade, ficando mais evidente, por analisar os dados de absorção de água, que a porcentagem de máxima densificação deva ser a de $4 \%$ em peso. Para $1125^{\circ} \mathrm{C}$, essa porcentagem é de $5 \%$ em peso. Isso evidencia o maior efeito da granulometria para temperaturas menores. 


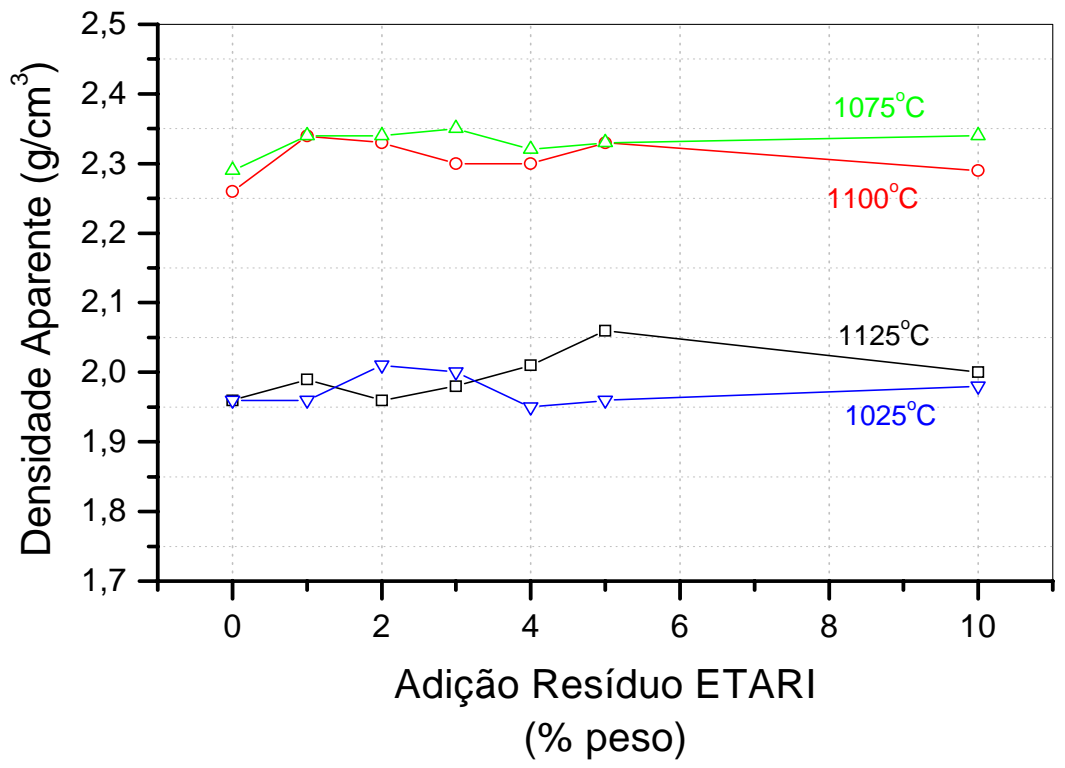

Figura 38: Densidade aparente de amostras queimadas de massa cerâmica contendo adições em peso de resíduo ETARI.

A densidade aparente a seco, de amostras a verde secas em estufa a $100^{\circ} \mathrm{C}$, que foram submetidas aos tratamentos térmicos descritos anteriormente, pode ser avaliada na figura 39, em que se observa, claramente, o efeito da granulometria do resíduo de ETARI, em que uma porcentagem de 1\% até 4\% em peso do resíduo aumenta a densidade, pela facilitação do empacotamento dos grãos devido à diferença na distribuição do tamanho dos grãos do resíduo e da massa cerâmica e porcentagens maiores diminuem a densidade, pelo aumento da quantidade de grãos de mesma distribuição granulométrica, que dificulta o empacotamento. 


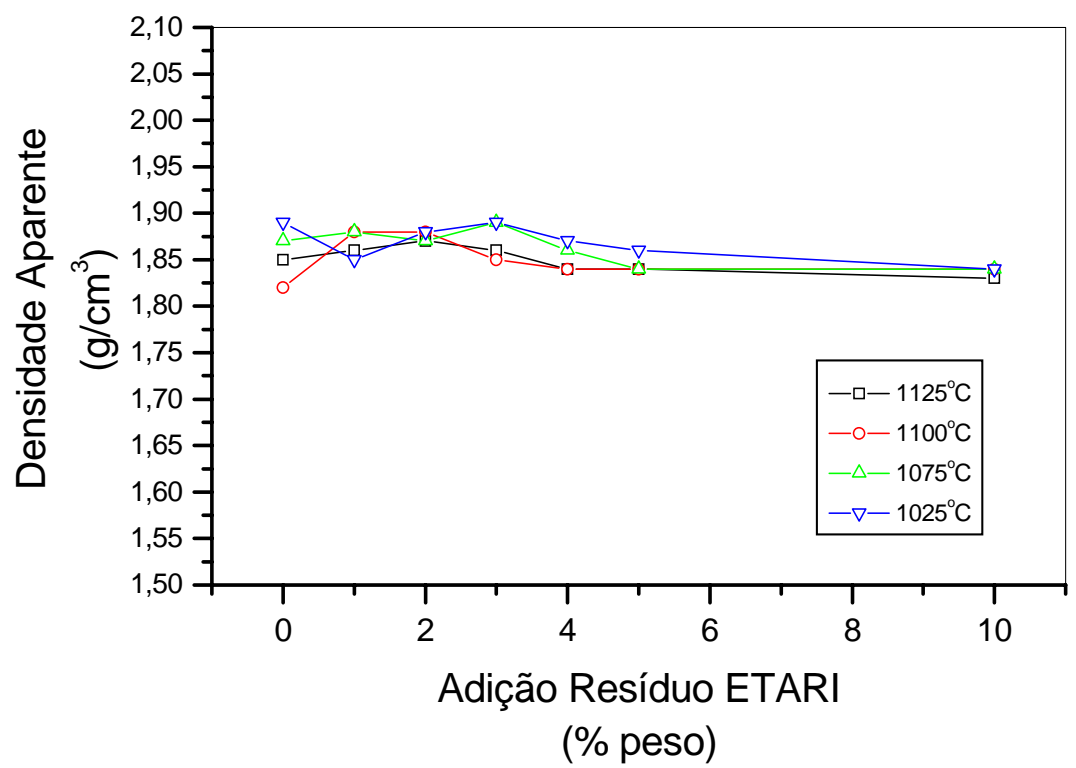

Figura 39: Densidade aparente a seco de amostras que foram submetidas à queima de massa cerâmica contendo adições em peso de resíduo ETARI.

A resistência mecânica pode ser avaliada em função do comportamento da retração linear e absorção de água. Se uma determinada peça apresenta retração linear alta, elevada densidade aparente e baixa porcentagem de absorção de água, ela provavelmente apresentará um módulo de resistência à flexão mais alto. Desse modo, ao se analisar a figura 40, observa-se a concordância entre o comportamento do módulo de resistência e as propriedades analisadas anteriormente.

Em relação à temperatura de queima, observa-se um aumento do módulo de resistência à flexão com o aumento da temperatura até $1100^{\circ} \mathrm{C}$, diminuindo em $1125^{\circ} \mathrm{C}$. Novamente se observa o comportamento análogo aos das demais propriedades devido aos mesmos motivos. 


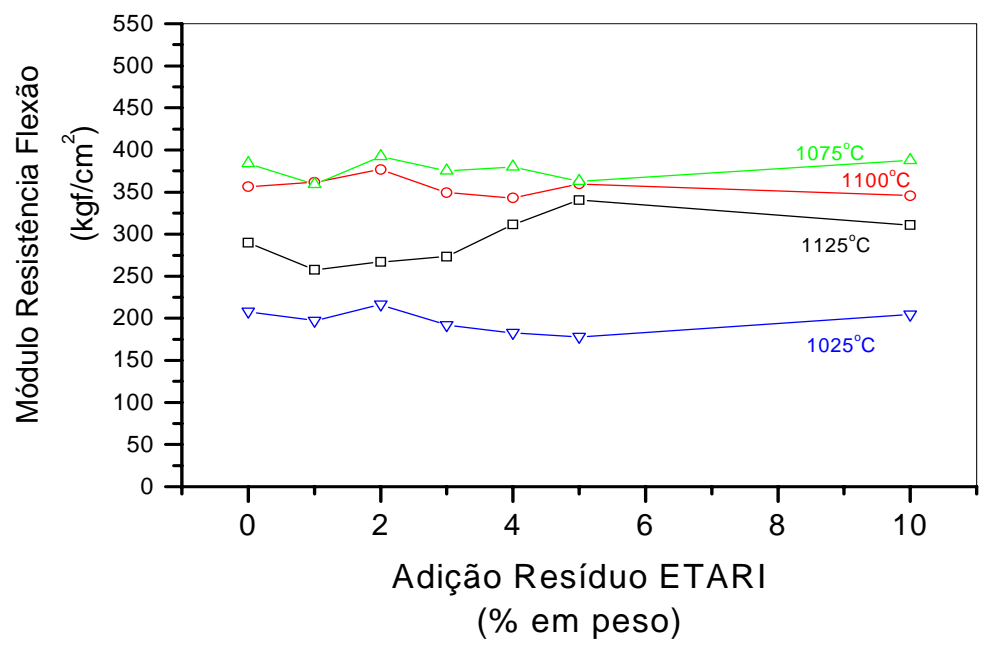

Figura 40: Módulo de resistência flexão 3 pontos de amostras de massa cerâmica contendo adições em peso de resíduo ETARI.

A resistência mecânica a seco, das amostras a verde contendo adições de resíduo, secas em estufa a $100^{\circ} \mathrm{C}$ por 24 horas, é condizente com os valores de densidade aparente, que evidencia o efeito da granulometria, onde a adição que fornece a maior resistência é de 4\% em peso (Figura 41).

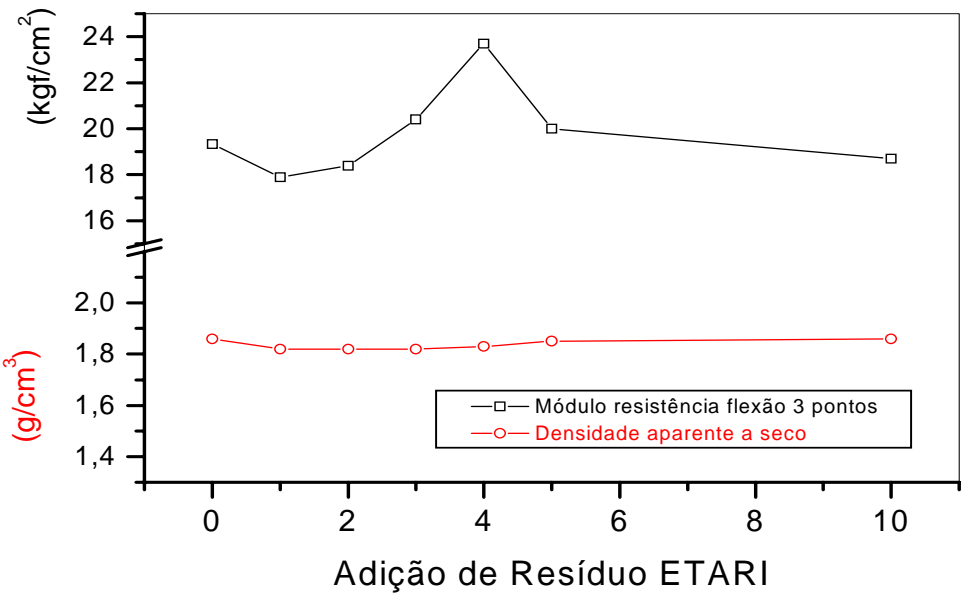

(\% peso)

Figura 41: Módulo de resistência flexão 3 pontos de amostras secas a $100^{\circ} \mathrm{C}$, de massa cerâmica contendo adições em peso de resíduo ETARI. 


\subsubsection{Avaliação das propriedades mecânicas de amostras da massa cerâmica contendo resíduo queimado.}

As argilas ilíticas são constituintes essenciais das argilas utilizadas em cerâmica vermelha, as substâncias que acompanham os sedimentos produzem evolução de gases durante a queima, o que provoca distorção e perda da forma das peças queimadas. Esse problema pode ser resolvido utilizando-se argila calcinada em mistura com a argila plástica ${ }^{*}$.

A reciclagem dos resíduos queimados, além de propor ações que minimizem o impacto ambiental provocado pelo entulho, aponta para a utilização como chamote, visando o controle dimensional das placas produzidas com argilas predominantemente ilíticas.

\subsubsection{A determinação da curva de gresificação da massa cerâmica contendo resíduo queimado fração 1}

As curvas de gresificação, obtidas através dos valores de porcentagem de absorção de água, retração linear e módulo de resistência à flexão em três pontos, são apresentadas na figura 42, cujas características confirmam a natureza mais refratária desses resíduos, sendo observado um deslocamento do ponto de gresificação, em relação à massa cerâmica padrão, para temperaturas mais elevadas.

A temperatura do início da expansão é mantida em $1100^{\circ} \mathrm{C}$, tal como nas amostras da massa cerâmica padrão, porém a intensidade do efeito é minimizada com a adição desses resíduos queimados.

\footnotetext{
* Esse procedimento é amplamente utilizado na Itália, onde chegam a adicionar até 15\% em peso de chamote à massa cerâmica, para controle dimensional das peças.
} 

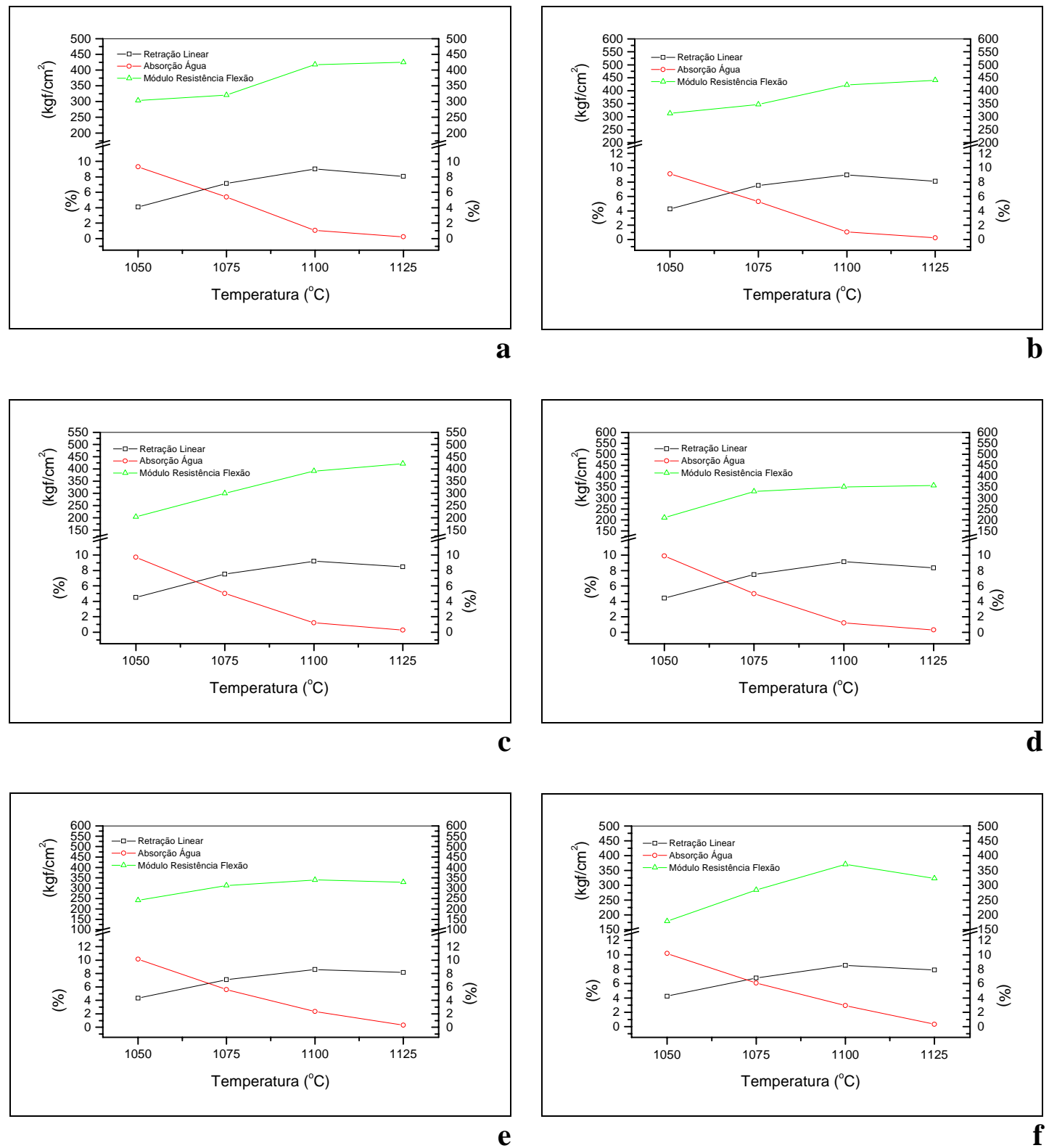

Figura 42: Curvas de gresificação da massa cerâmica contendo adições de resíduo queimado Fração 1, (a) 1\% em peso, (b) 2\% em peso, (c) 3\% em peso, (d) 4\% em peso, (e) $5 \%$ em peso e (f) $10 \%$ em peso. 
Em relação à adição desses resíduos queimados, a temperatura de início de gresificação aumentou consideravelmente em relação à massa cerâmica, porém, com relação às adições, ocorre uma pequena diminuição com a adição de até 3\% em peso, devido à melhor distribuição granulométrica que ocorre pela interação entre os grãos que compõem a massa cerâmica, com uma quantidade maior de finos, e os resíduos com grãos maiores. A partir dessa quantidade de resíduo, as adições provocam um aumento da temperatura de gresificação, pois esses grãos maiores prejudicam o empacotamento dos grãos na mistura (Fig. 43).

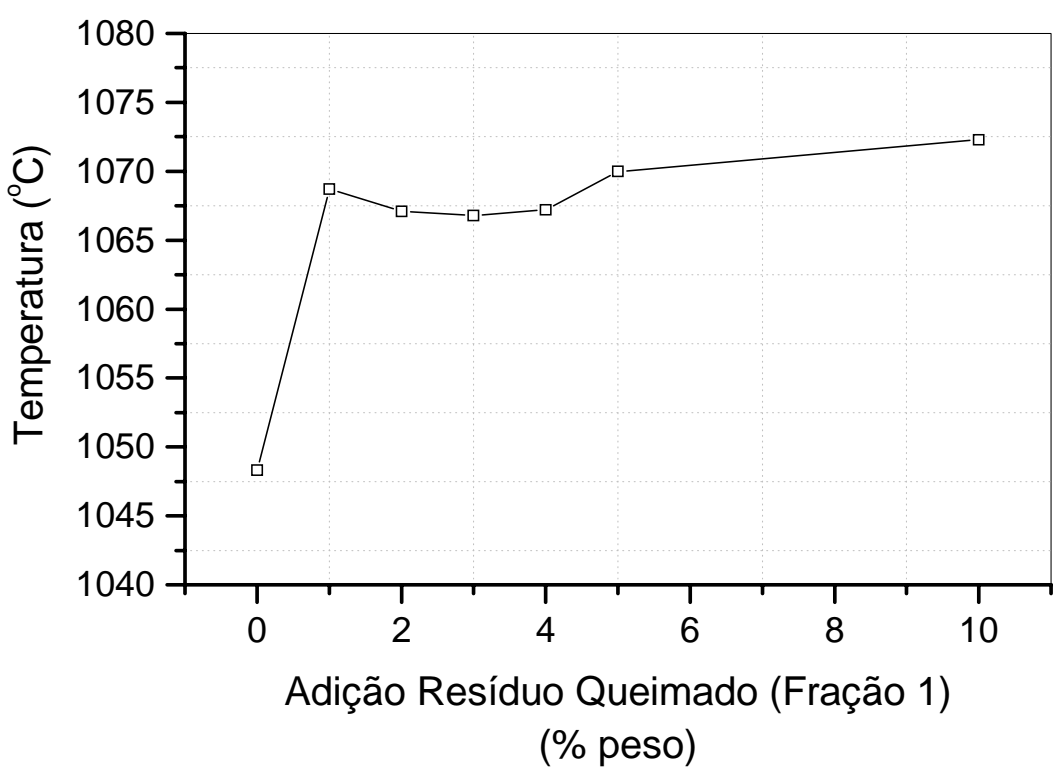

Figura 43: Temperatura do ponto de gresificação de amostras de massa cerâmica contendo adições em peso de resíduo queimado fração 1.

Analisando a absorção de água em função da presença desses resíduos queimados, observa-se o aumento na porcentagem para todas as temperaturas de queima, em relação á massa cerâmica padrão. Em $1050^{\circ} \mathrm{C}$, o efeito da distribuição granulométrica não produz interferência no comportamento de queima, ou seja, a medida que se adicionam os resíduos, a porcentagem de absorção de água aumenta, porque a temperatura não é suficiente para promover a adequada gresificação das 
amostras. Na temperatura de $1075^{\circ} \mathrm{C}$, esse efeito já é observado, uma vez que a absorção de água diminui das amostras com 1\% até 4\% em peso e aumenta em seguida até $10 \%$ em peso. Em $1100^{\circ} \mathrm{C}$ e $1125^{\circ} \mathrm{C}$ esse comportamento é mantido. A absorção de água fica constante até a adição de 4\% em peso, aumentando em seguida. Para a temperatura de $1125^{\circ} \mathrm{C}$, a absorção de água aumenta com a adição dos resíduos até 5\% em peso, quando se torna constante até 10\% (Figura 44).

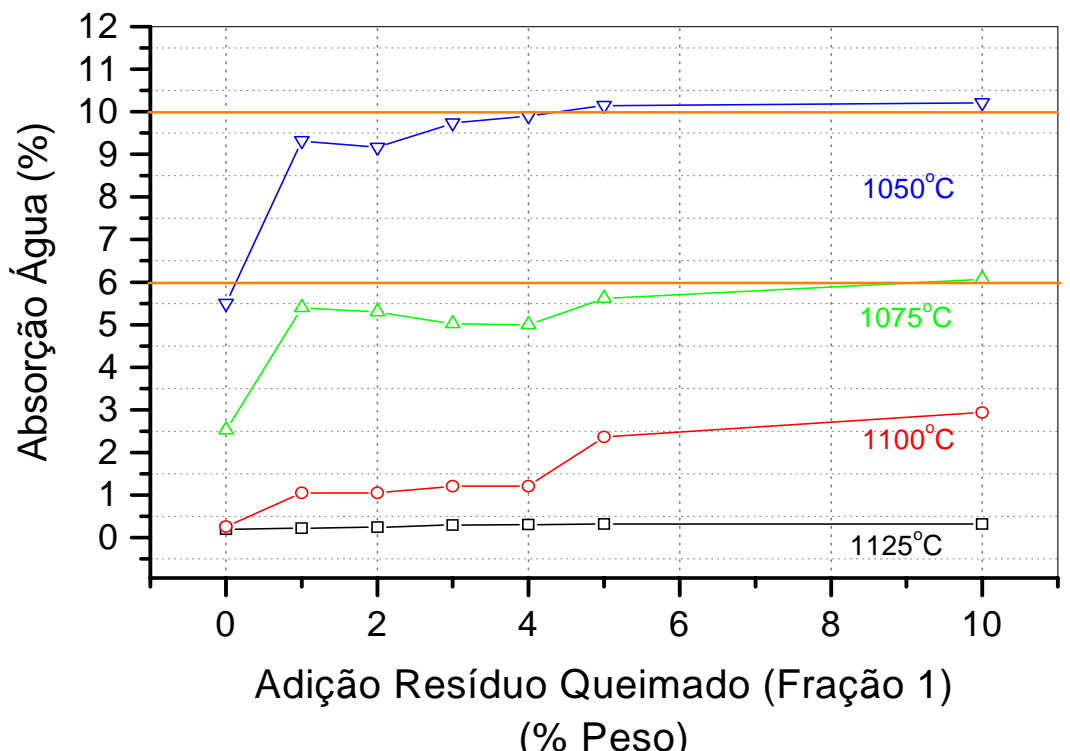

Figura 44: Absorção de água de amostras de massa cerâmica contendo adições em peso de resíduo queimado fração 1 .

De modo análogo ao do estudo das amostras contendo resíduo de ETARI, em relação à temperatura de queima, a retração linear das amostras aumenta de $1050^{\circ} \mathrm{C}$ até $1100^{\circ} \mathrm{C}$, devido ao processo normal de sinterização e diminui em $1125^{\circ} \mathrm{C}$, devido à expansão provocada pelos gases residuais nas amostras (Figura 45).

A adição de resíduo queimado promove uma menor retração linear, em relação à massa cerâmica padrão, devido à sua natureza química mais inerte e tamanho de grãos maiores, que dificulta o processo de densificação. Porém a retração linear diminui com as adições até 3\% em peso, quantidade que confere maior 
densidade ao balanço granulométrico da mistura, crescendo com o aumento da porcentagem de resíduos. Esse comportamento da retração linear com a adição dos resíduos é observado nas amostras queimadas nas temperaturas de $1050^{\circ} \mathrm{C}$ até $1100^{\circ} \mathrm{C}$. Em $1125^{\circ} \mathrm{C}$, a adição do resíduo aumenta a retração linear em relação à massa cerâmica, uma vez que a presença de uma superfície mais porosa facilita o processo de adsorção e/ou saída dos gases residuais, diminuindo a sua pressão no interior do corpo cerâmico, resultando em menor expansão da peça.

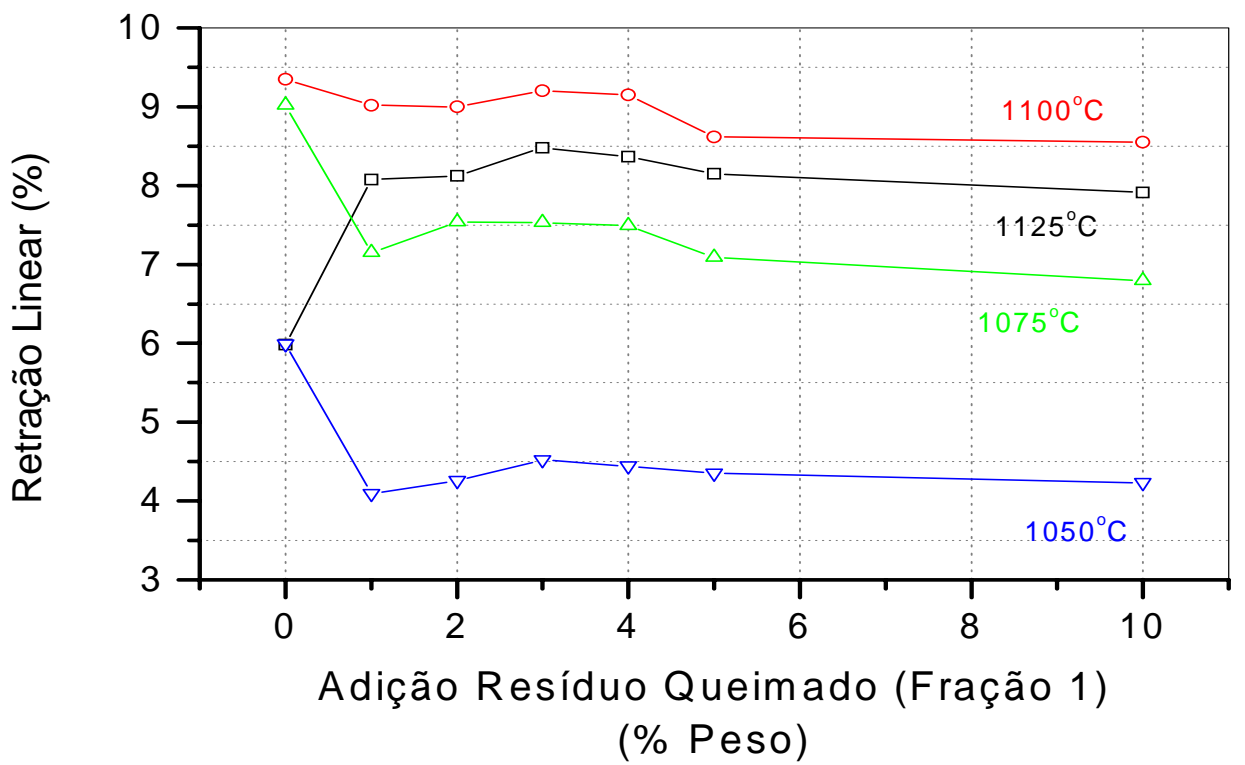

Figura 45: Retração linear de amostras de massa cerâmica contendo adições em peso de resíduo queimado fração 1 .

As medidas de porosidade aparente das amostras (Figura 46), estão de acordo com os resultados das análises de absorção de água, visto que uma reflete o comportamento da outra. 


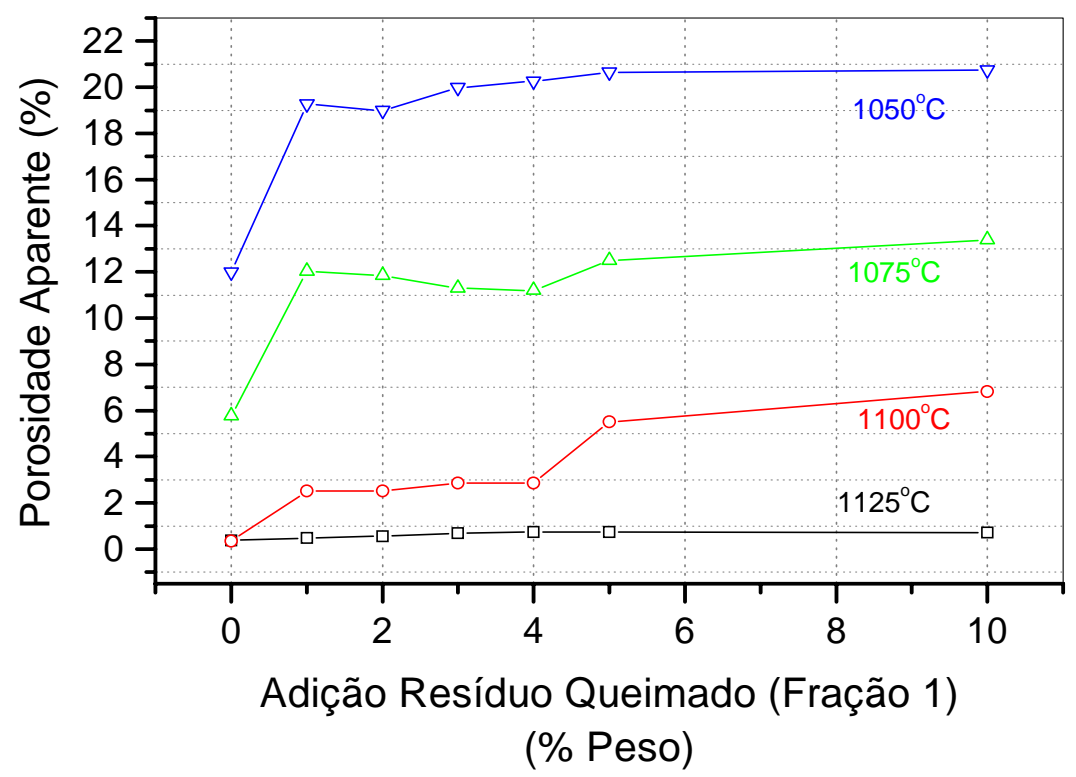

Figura 46: Porosidade aparente de amostras de massa cerâmica contendo adições em peso de resíduo queimado fração 1 .

A densidade aparente das amostras queimadas cresce, com o aumento da temperatura, até $1100^{\circ} \mathrm{C}$ e diminui, devido à expansão dos gases residuais, em $1125^{\circ} \mathrm{C}$ (Figura 47). Ao se adicionar os resíduos queimados com grãos menores que 0,30mm na massa cerâmica padrão, ocorre um aumento da densidade aparente para as menores adições, sendo $1 \%$ em peso na temperatura de queima de $1050^{\circ} \mathrm{C}$, aumentando para $3 \%$ em peso em $1075^{\circ} \mathrm{C}$, dado o início do processo de sinterização, mantendo-se muito próximos entre $1 \%$ e $3 \%$ em peso em $1100^{\circ} \mathrm{C}$, diminuindo mais acentuadamente em adições maiores, e 3\% em peso em $1125^{\circ} \mathrm{C}$. Essas alterações ocorrem, por ser a temperatura adequada para promover a densificação das amostras, contendo uma maior porcentagem desses resíduos com granulometria maior.

Em relação à massa cerâmica, nas temperaturas mais baixas a adição dos resíduos não é favorável, uma vez que diminuem a densidade aparente das peças queimadas, porém é conveniente adicioná-los quando for utilizada temperatura de queima maior, como em $1100^{\circ} \mathrm{C}$ e $1125^{\circ} \mathrm{C}$, onde os resíduos provocam o aumento da densidade do material. 


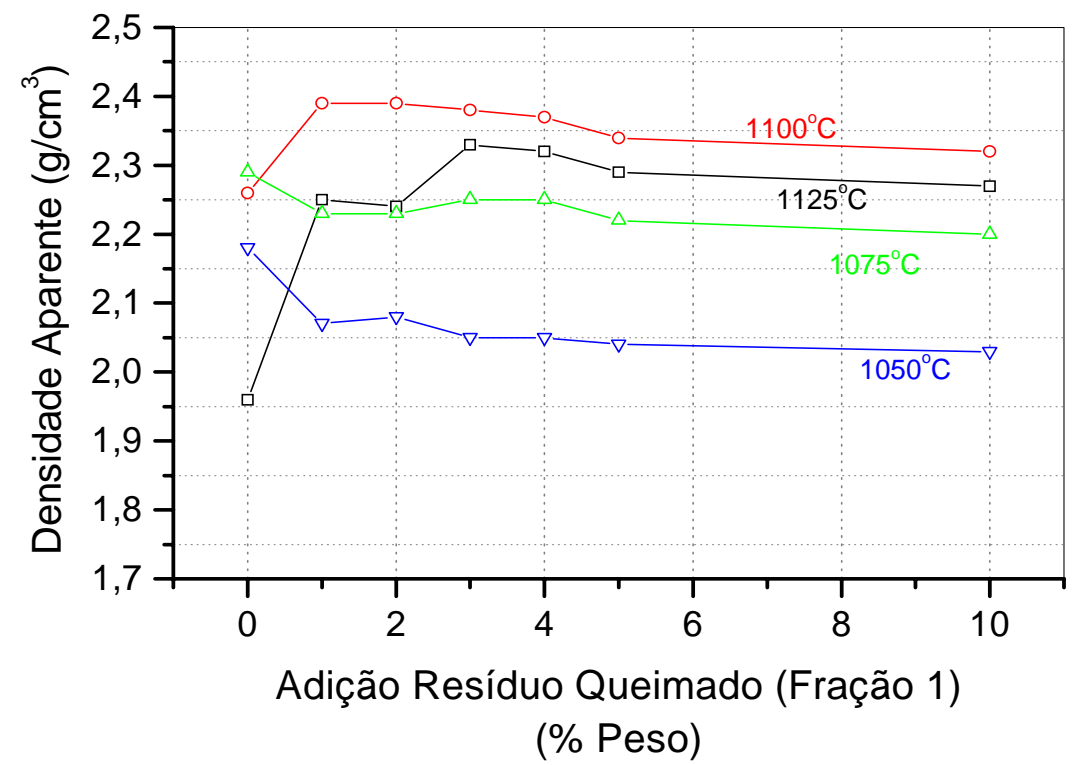

Figura 47: Densidade aparente de amostras queimadas de massa cerâmica contendo adições em peso de resíduo queimado fração 1 .

A densidade aparente a seco, de amostras a verde secas em estufa a $100^{\circ} \mathrm{C}$, que foram submetidas aos tratamentos térmicos descritos anteriormente, pode ser avaliada na figura 48, onde se observa que a densidade é favorecida quando os resíduos queimados são adicionados em quantidades bem menores, no máximo de 2\% em peso, sendo prejudicada, em adições maiores, porém, ainda assim apresentando-se maior do que a densidade das amostras da massa cerâmica padrão. 


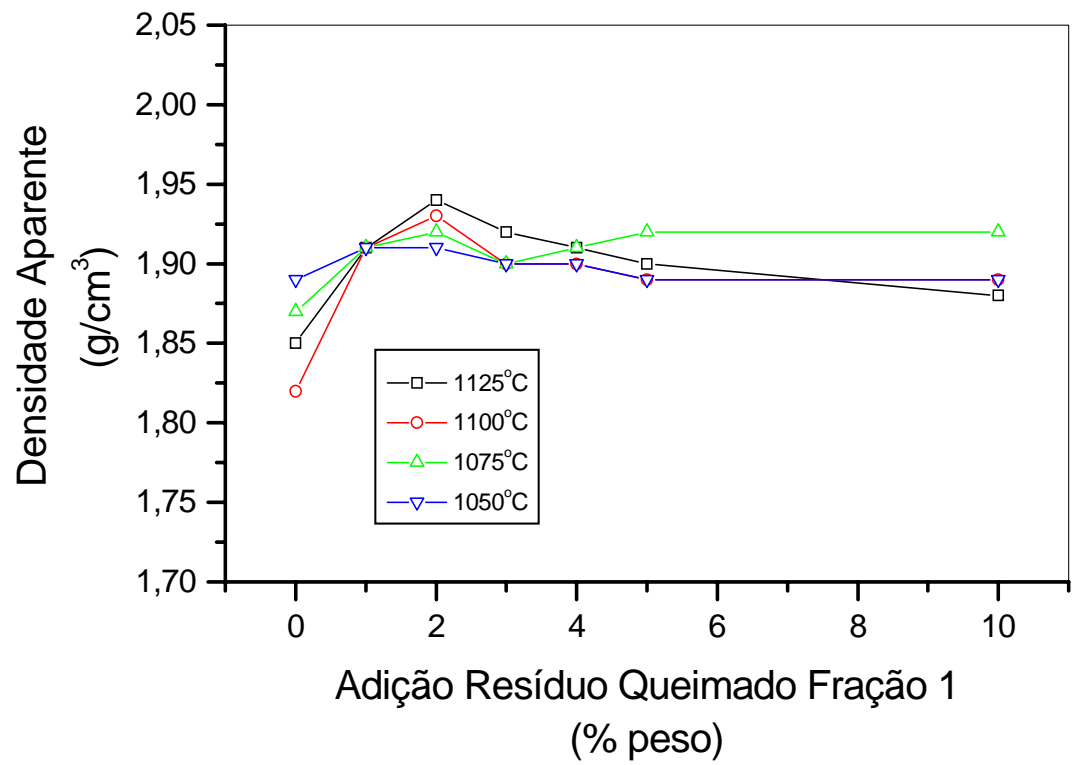

Figura 48: Densidade aparente de amostras secas de massa cerâmica contendo adições em peso de resíduo queimado Fração 1.

A resistência mecânica após a queima das amostras é apresentada na figura 49, na qual o comportamento do módulo de resistência à flexão em três pontos reflete as características das outras propriedades avaliadas anteriormente. As curvas apresentadas são muito similares às obtidas quando adicionados os resíduos de ETARI, sendo observada a diminuição da porcentagem de adição para $2 \%$ em peso. Na temperatura de $1125^{\circ} \mathrm{C}$ o efeito de expansão das peças não é observado quando se adiciona até $4 \%$ em peso do resíduo queimado e, em todas as adições, observa-se que o efeito de expansão apresentado pela massa cerâmica padrão é bastante minimizado.

Para as amostras secas em estufa a $100^{\circ} \mathrm{C}$ durante 24 horas, o módulo de resistência à flexão é máximo em adição de 3\% em peso, diminuindo devido ao efeito granulométrico, para as demais adições (Figura 50). 


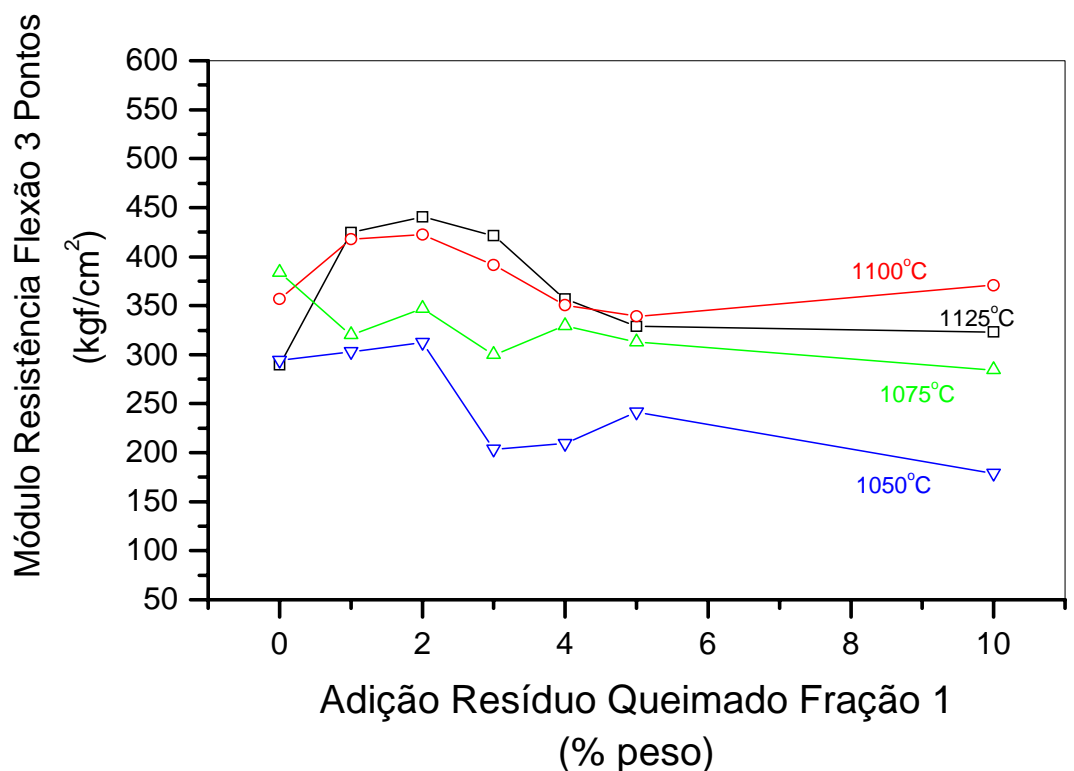

Figura 49: Módulo de resistência flexão 3 pontos de amostras queimadas de massa cerâmica contendo adições em peso de resíduo queimado fração 1.

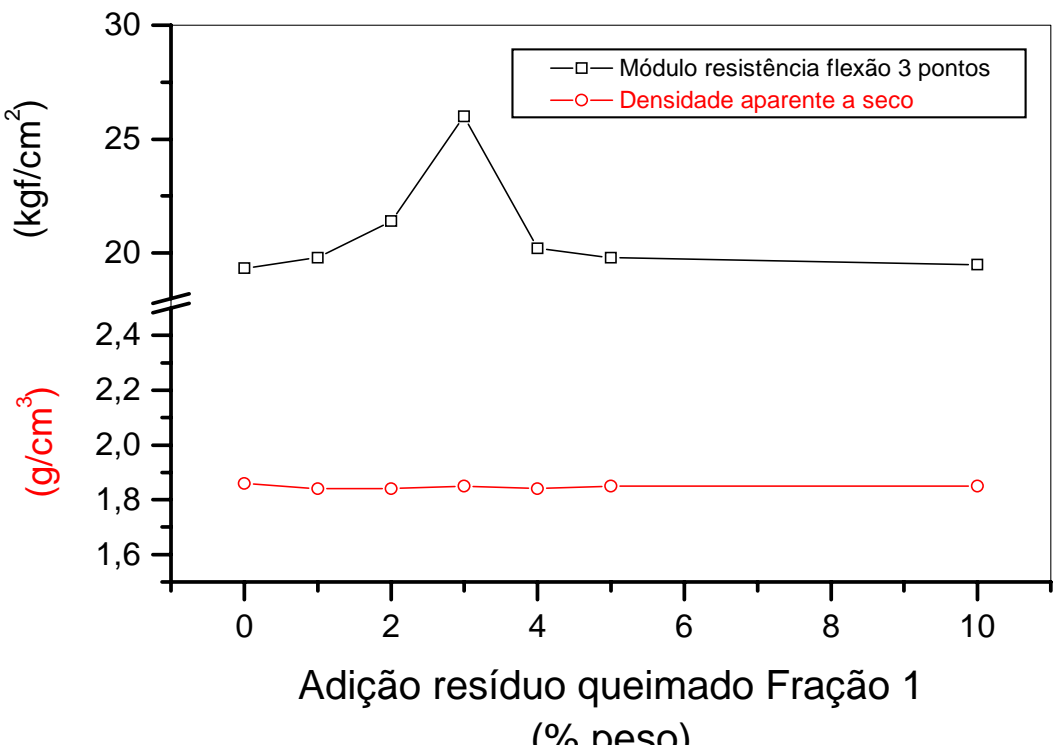

Figura 50: Módulo de resistência flexão 3 pontos de amostras secas a $100^{\circ} \mathrm{C}$, de massa cerâmica contendo adições em peso de resíduo queimado fração 1. 


\subsubsection{A determinação da curva de gresificação da massa cerâmica contendo resíduo queimado fração 2.}

As curvas de gresificação das amostras contendo resíduo queimado fração 2 são apresentadas na figura 51, onde se observa um deslocamento da temperatura do ponto de gresificação para temperaturas maiores, em relação à massa padrão, mas com menor intensidade em relação ao resíduo queimado fração 1.

Na figura 52 pode-se avaliar melhor esse efeito do deslocamento do ponto de gresificação, o qual se apresenta de maneira linear, ou seja, a medida em que se aumenta a porcentagem de resíduo adicionado, maior é o deslocamento provocado. De modo diferente do resíduo fração 1 , a fração 2 não apresenta a diminuição do deslocamento do ponto de gresificação, à medida que se adicionam os resíduos, devido á sua granulometria, cuja distribuição dos tamanhos de grãos é estreita, não promovendo uma balanço granulométrico eficiente com os grãos da massa cerâmica.

A porcentagem de absorção de água das amostras contendo os resíduos fração 2 apresentou-se muito similar à da fração 1, diferindo apenas na quantidade máxima de resíduo que pode ser adicionado à massa cerâmica queimada em $1050^{\circ} \mathrm{C}$, que foi de 4\% em peso (Figura 53).

Com grãos menores, o resíduo fração 2 promove uma diminuição da retração linear em baixas temperaturas (Figura 54) e um aumento da retração linear em altas temperaturas, com menor intensidade; isso significa que sua utilização pode ser mais vantajosa por controlar o processo de densificação nas temperaturas mais baixas e facilitar o processo nas temperaturas mais altas. O motivo desse comportamento é o mesmo já comentado para a fração 1 . 

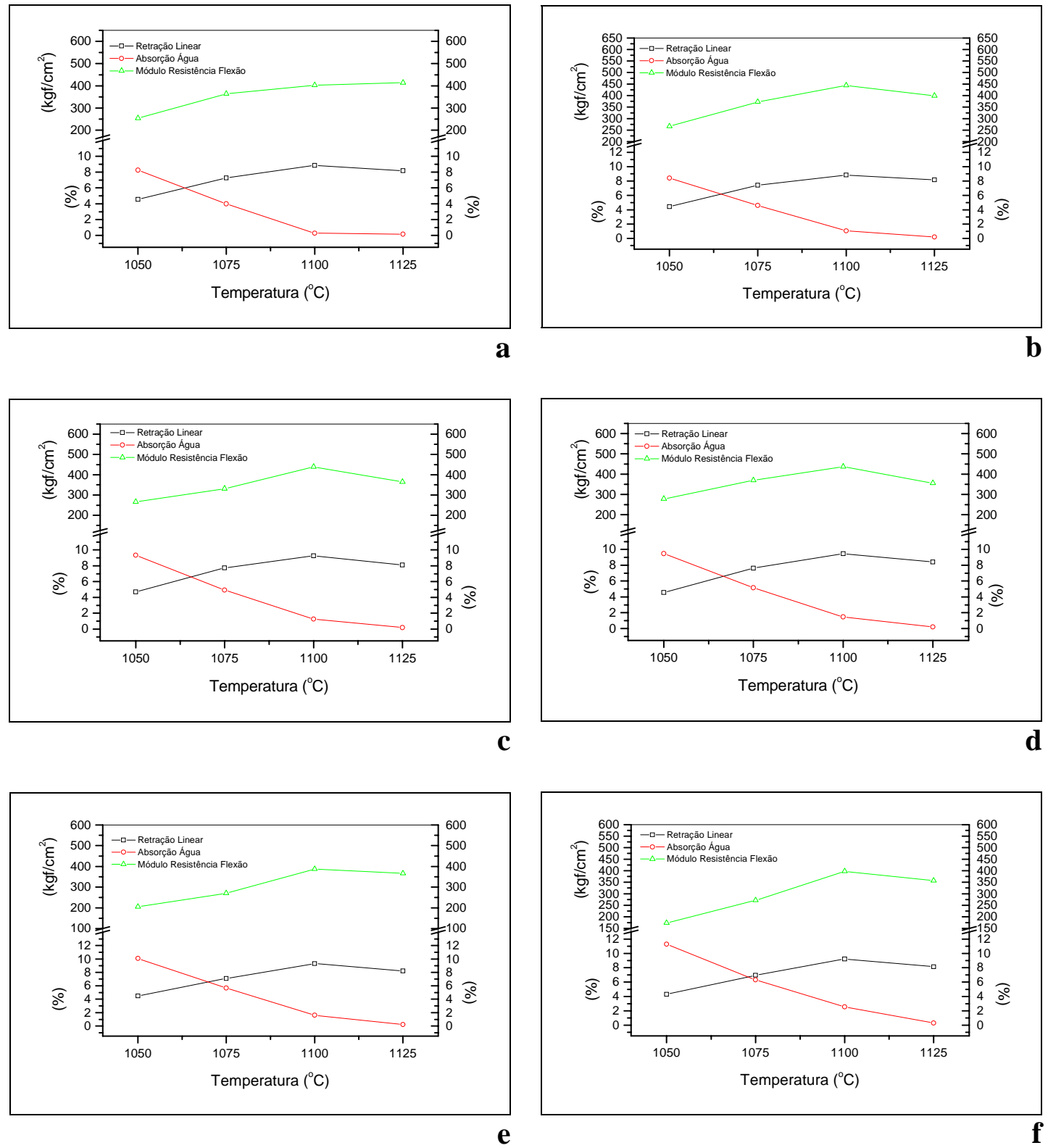

Figura 51: Curvas de gresificação da massa cerâmica contendo adições de resíduo queimado Fração 2, (a) 1\% em peso, (b) 2\% em peso, (c) 3\% em peso, (d) 4\% em peso, (e) $5 \%$ em peso e (f) $10 \%$ em peso. 


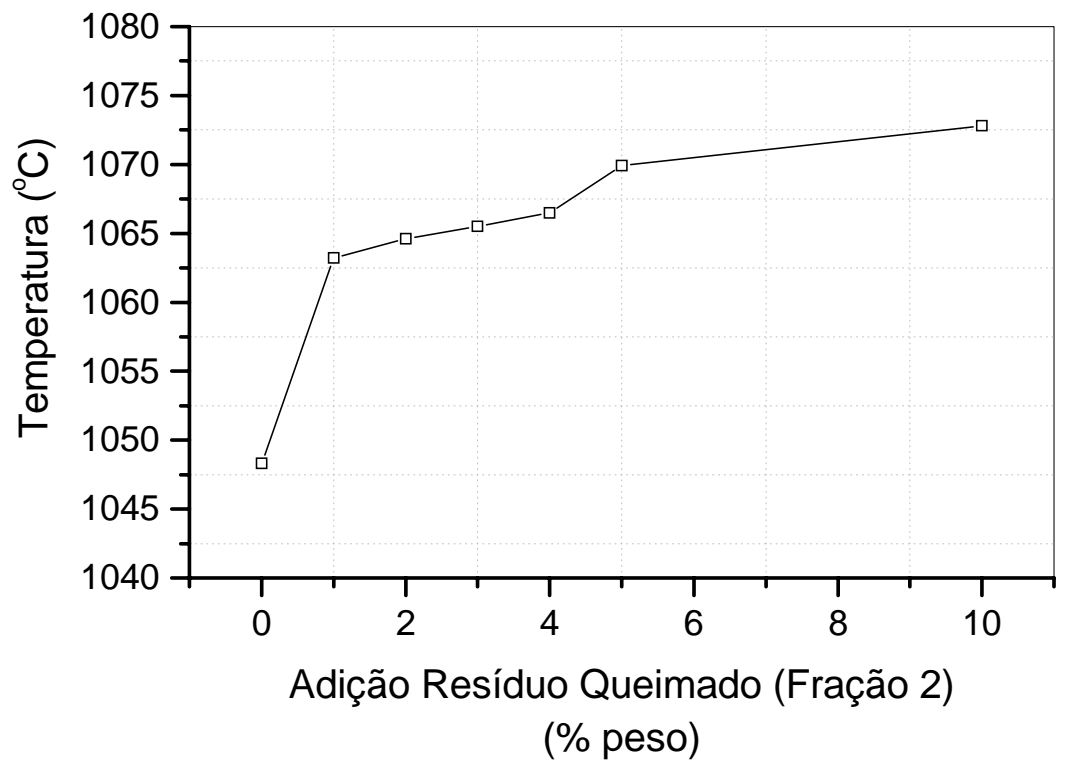

Figura 52: Temperatura do ponto de gresificação, de amostras queimadas de massa cerâmica contendo adições em peso de resíduo queimado fração 2.

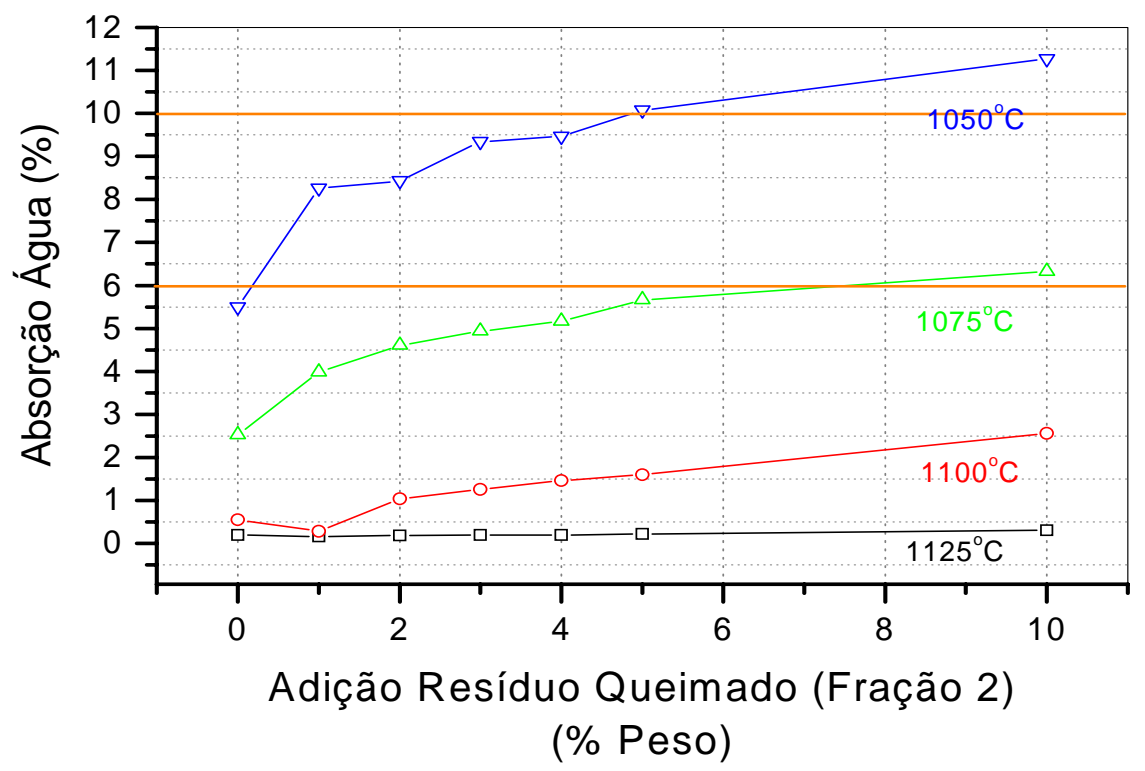

Figura 53: Absorção de água de amostras queimadas de massa cerâmica contendo adições em peso de resíduo queimado fração 2. 


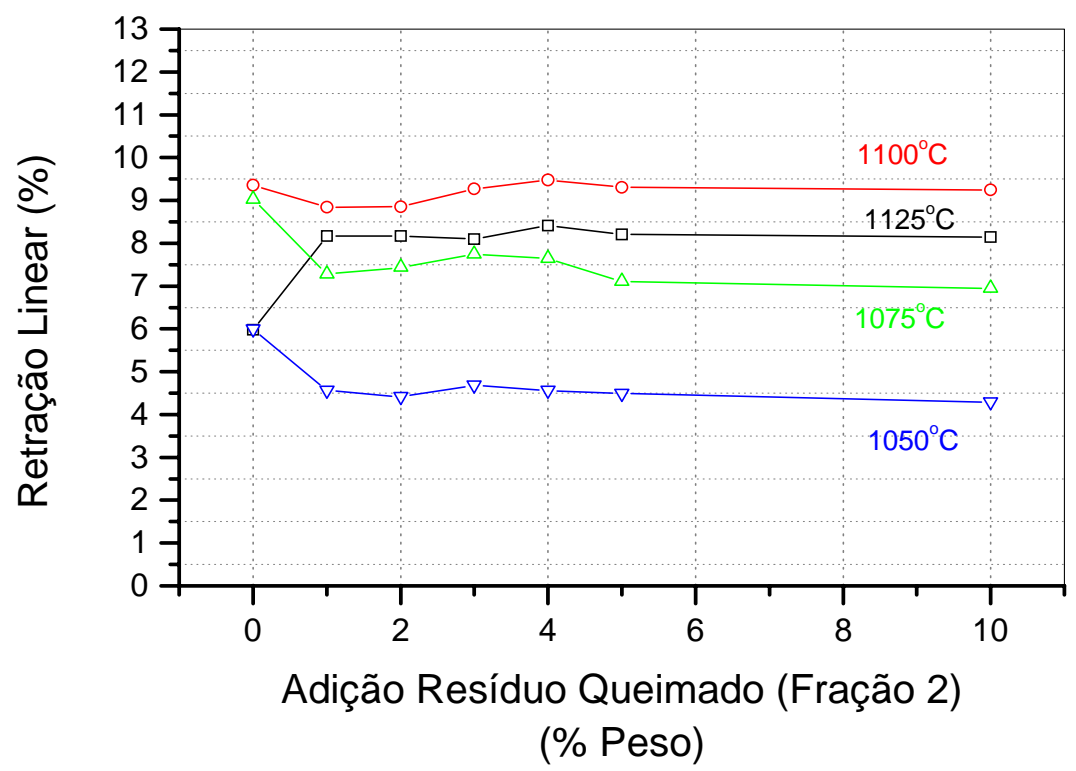

Figura 54: Retração linear seco-queimado de amostras de massa cerâmica contendo adições em peso de resíduo queimado fração 2.

Novamente, as medidas de porosidade aparente das amostras queimadas (Figura 55), estão de acordo com os resultados das análises de absorção de água, visto que uma reflete o comportamento da outra.

A figura 56 apresenta as curvas de densidade aparente das amostras queimadas, em função da adição dos resíduos queimados fração 2. Pode-se observar que o aumento da adição do resíduo promove uma diminuição na densidade aparente das amostras queimadas nas temperaturas mais baixas e um aumento na densidade das amostras queimadas nas temperaturas mais altas. Esse comportamento já foi explicado nas considerações sobre a adição de resíduo queimado fração 1, porém a intensidade com que ocorre é bem menor, chegando a quase não promover alterações quando as peças são queimadas em $1100^{\circ} \mathrm{C}$. 


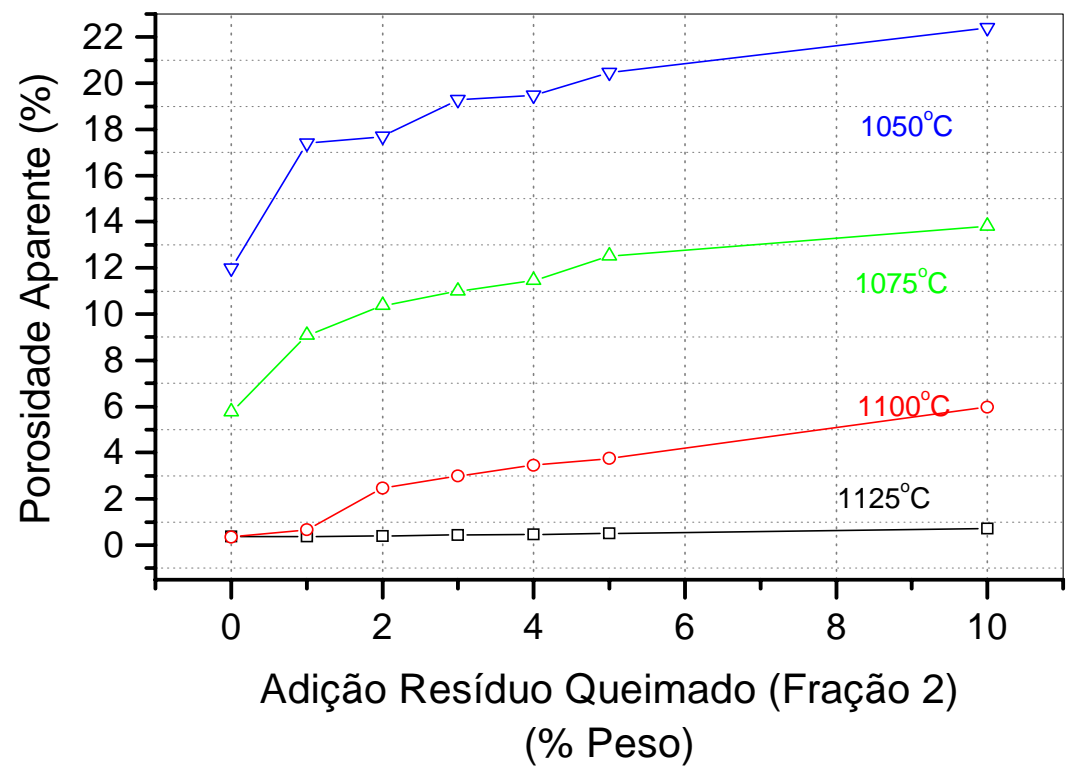

Figura 55: Porosidade aparente de amostras de massa cerâmica contendo adições em peso de resíduo queimado fração 2.

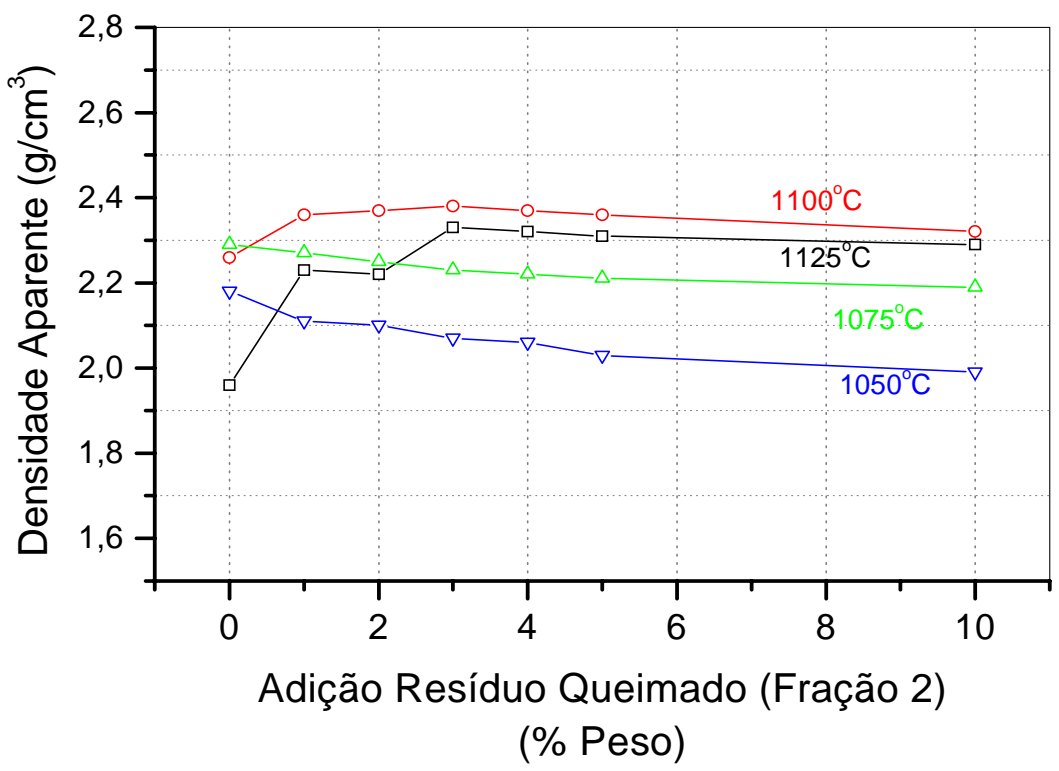

Figura 56: Densidade aparente de amostras queimadas de massa cerâmica contendo adições em peso de resíduo queimado fração 2 . 
A densidade aparente a seco, de amostras a verde secas em estufa a $100^{\circ} \mathrm{C}$, durante 24 horas, é sensivelmente comprometida quando se adicionam os resíduos queimados fração 2 (Figura 57), sendo favorecidas as adições com menores porcentagens. Embora a influência desses resíduos seja acentuada, esses valores de densidade aparente a seco não promovem consideradas influências sobre a densidade das peças queimadas, de acordo com a figura 56. O módulo de resistência à flexão em 3 pontos das amostras queimadas, contendo adições de resíduo queimado fração 2 é apresentado na figura 58

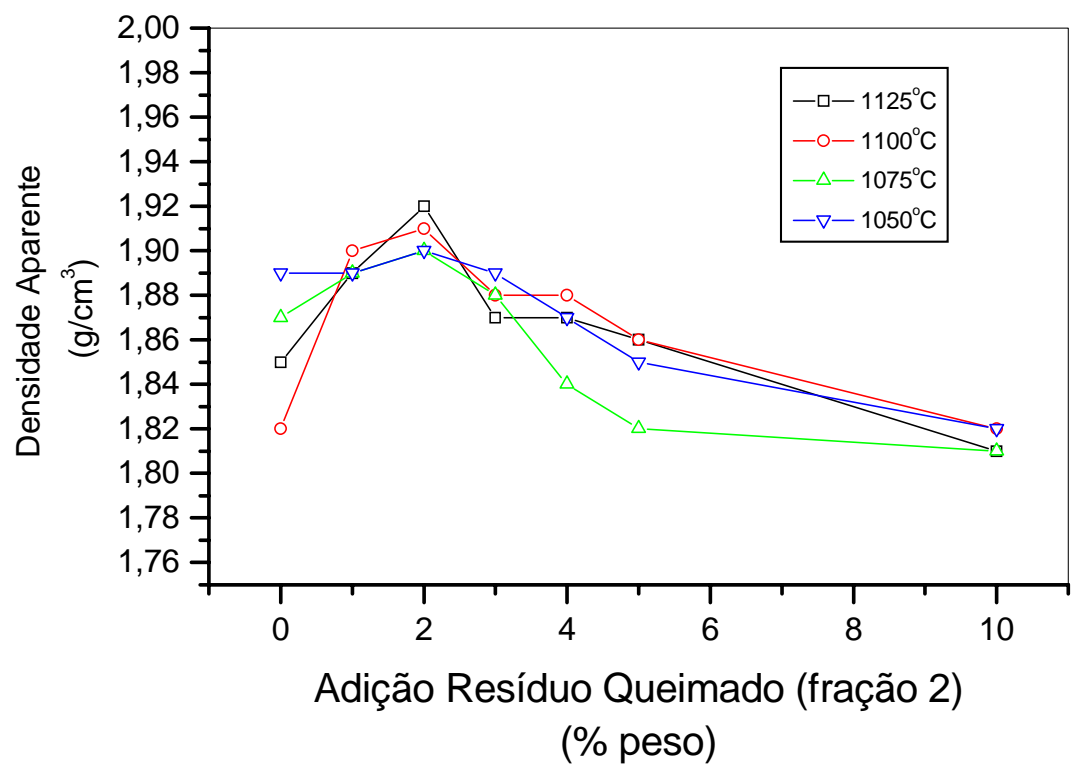

Figura 57: Densidade aparente de amostras a seco de massa cerâmica contendo adições em peso de resíduo queimado fração 2.

A figura 59 apresenta o módulo de resistência a flexão em três pontos para amostras secas em estufa a $100^{\circ} \mathrm{C}$ por 24 horas, onde se observa que a melhor adição do resíduo é a de 1\% em peso, embora as demais ainda apresentem valores maiores que os da massa cerâmica padrão, mas essa pequena quantidade é devido à má 
distribuição dos tamanhos de grãos, que dificultam o empacotamento dos grãos durante a prensagem.

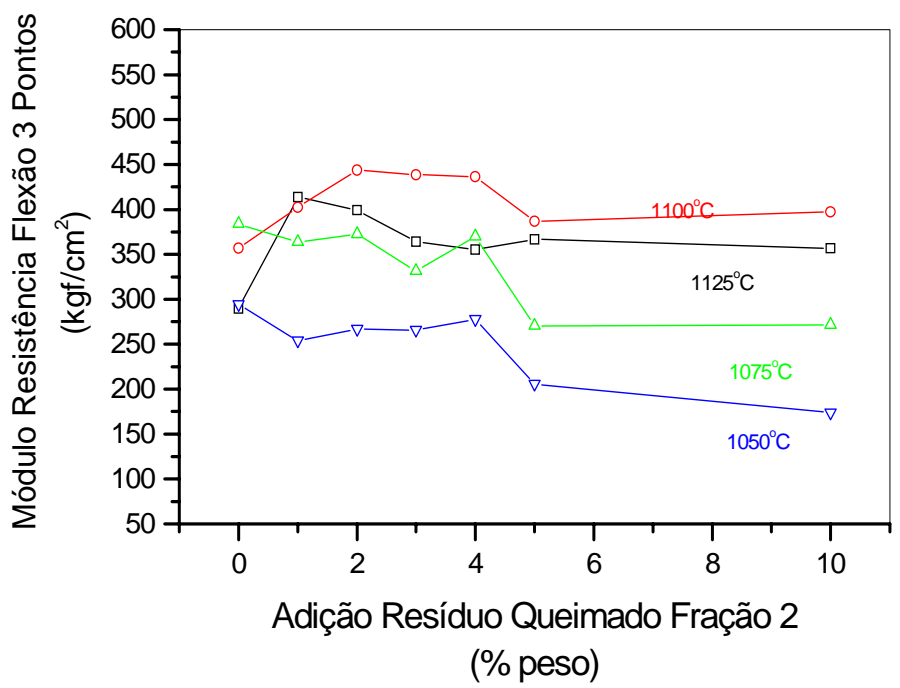

Figura 58: Módulo de resistência flexão 3 pontos de amostras queimadas de massa cerâmica contendo adições em peso de resíduo queimado fração 2.

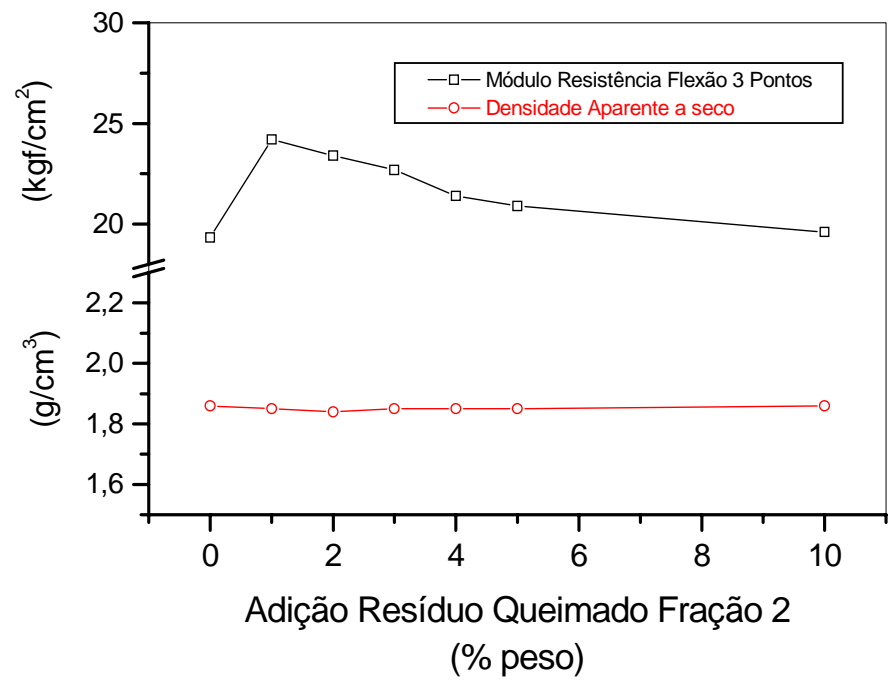

Figura 59: Módulo de resistência flexão 3 pontos de amostras secas a $100^{\circ} \mathrm{C}$, de massa cerâmica contendo adições em peso de resíduo queimado fração 2. 


\subsubsection{Avaliação das propriedades mecânicas de amostras da massa cerâmica contendo adição conjunta de resíduos de ETARI e Queimado fração 1.}

Mediante a natureza fundente dos resíduos de ETARI e da natureza mais refratária dos resíduos queimados, que podem gerar alguns inconvenientes quando adicionados isoladamente, foram avaliadas duas composições contendo adições conjuntas desses resíduos, em mesma proporção, mas com porcentagens em peso diferentes em relação à massa padrão, visando a verificação de mais uma possibilidade de reciclagem dos resíduos.

Na figura 60 são apresentadas as curvas de gresificação das composições contendo 3\% e 10\% em peso de cada resíduo. Pode-se observar que as temperaturas de início de gresificação das composições não variam significativamente, de $1050,9^{\circ} \mathrm{C}$ em $3 \%$ em peso para $1051,3^{\circ} \mathrm{C}$ em $10 \%$ em peso. De modo análogo, a porcentagem de absorção de água e retração linear apresentou pouca variação indo, de $6,35 \%$ em $3 \%$ em peso, para $6,55 \%$ em $10 \%$ em peso.
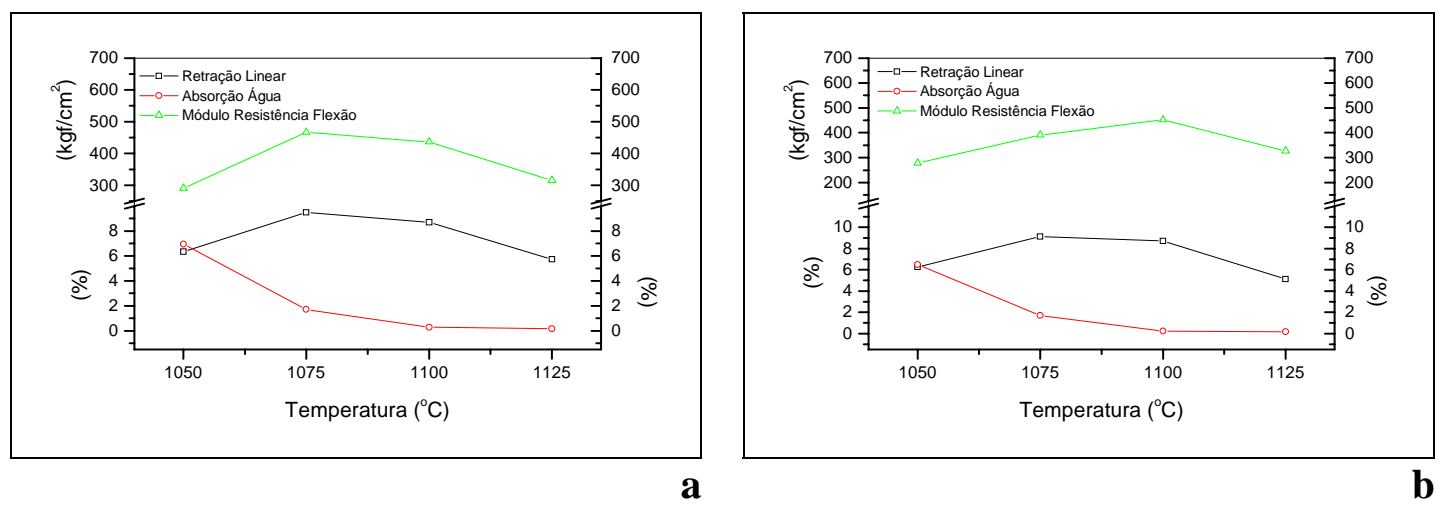

Figura 60: Curvas de gresificação da massa cerâmica contendo adição conjunta de resíduos de ETARI e Queimado Fração 1, (a) 10\% em peso, (b) 3\% em peso. 
O módulo de resistência à flexão de amostras queimadas (Figuras 60 e 61) é maior na composição com $10 \%$ em peso dos resíduos, devido à maior quantidade de resíduo queimado presente, porém é máximo na temperatura de $1075^{\circ} \mathrm{C}$, diminuindo nas demais, devido à elevada quantidade de resíduo de ETARI. Na composição com $3 \%$ em peso dos resíduos, o módulo de resistência à flexão é máximo em $1100^{\circ} \mathrm{C}$, por ser menor a quantidade de resíduo fundente, exigindo maior temperatura para a queima, porém é menor que em $10 \%$ em peso devido à quantidade de resíduo refratário ser menor.

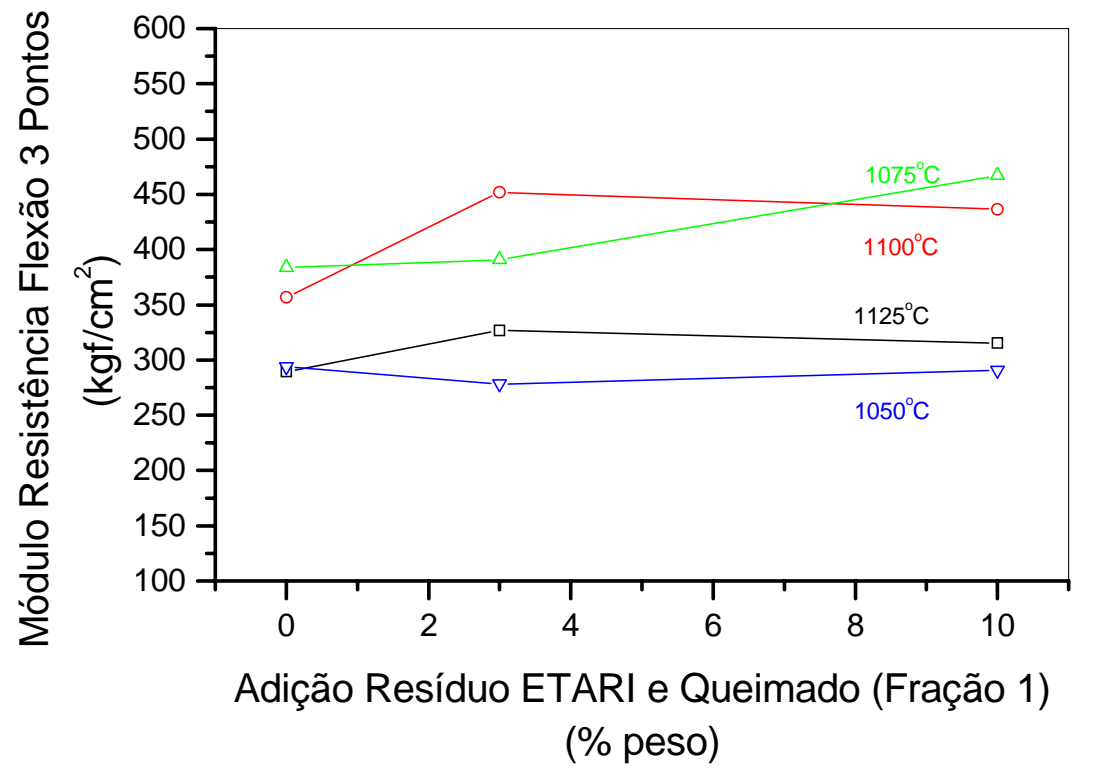

Figura 61: Módulo de resistência flexão 3 pontos de amostras queimadas de massa cerâmica contendo adição conjunta em peso de resíduos de ETARI e Queimado fração 1.

Com relação à quantidade de resíduo adicionado, a absorção de água é menor na composição com 3\% em peso dos resíduos em todas as temperaturas de queima, uma vez que, quanto maior a adição dos resíduos queimados com granulometria grosseira, maior é a possibilidade de se formar poros, devido à dificuldade em 
sinterizar os grãos maiores, mesmo com a adição de material fundente. Nesse caso, porém, a diferença não é tão grande (Figura 62).

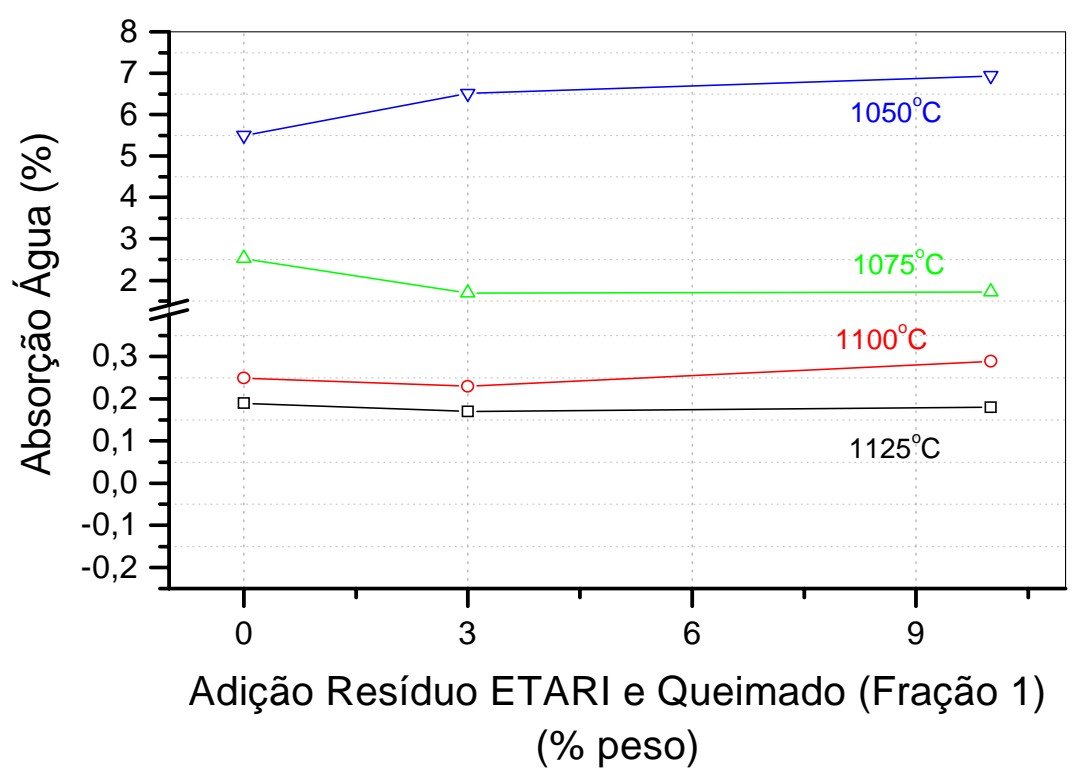

Figura 62: Absorção de água de amostras queimadas de massa cerâmica contendo adição conjunta em peso de resíduos de ETARI e Queimado fração 1.

A retração linear seco-queimado (Figura 63), embora próxima, aumenta com o aumento da porcentagem dos resíduos. Com relação à temperatura de queima, a retração linear aumenta de $1050^{\circ} \mathrm{C}$ e $1075^{\circ} \mathrm{C}$, devido ao processo de sinterização normal que é facilitado pela presença do resíduo de ETARI, e diminui a partir de $1100^{\circ} \mathrm{C}$, devido à expansão provocada pelos gases residuais nas amostras, em $1125^{\circ} \mathrm{C}$ a retração linear é menor em amostras com 3\% em peso dos resíduos. Isto ocorre porque a presença dos resíduos queimados que geram uma certa porosidade e facilitam a saída e/ou a adsorção dos gases é menor, em comparação com a adição de 10\% em peso dos resíduos. 


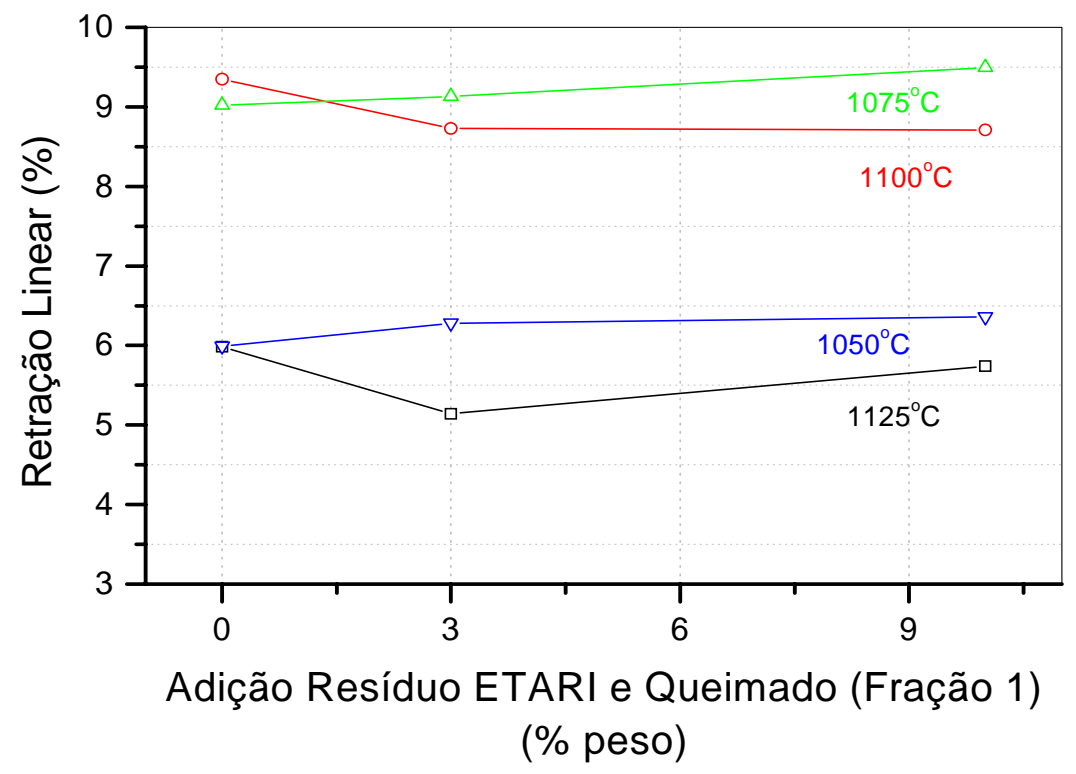

Figura 63: Retração linear seco-queimado de amostras de massa cerâmica contendo adição conjunta em peso de resíduos de ETARI e Queimado fração 1.

A figura 64 apresenta as curvas de densidade aparente de amostras queimadas em função da quantidade de resíduo adicionado. Pode-se observar que a quantidade de $10 \%$ em peso promove maior porosidade na peça, diminuindo a densidade aparente, em todas as temperaturas de queima, com relação à composição contendo $3 \%$ em peso dos resíduos. Com relação à massa padrão, apenas a composição contendo $10 \%$ em peso dos resíduos, queimada em $1050^{\circ} \mathrm{C}$, apresentou menor densidade aparente que a massa padrão. As demais composições contendo os resíduos, em todas as temperaturas de queima, apresentaram maior densidade aparente. 


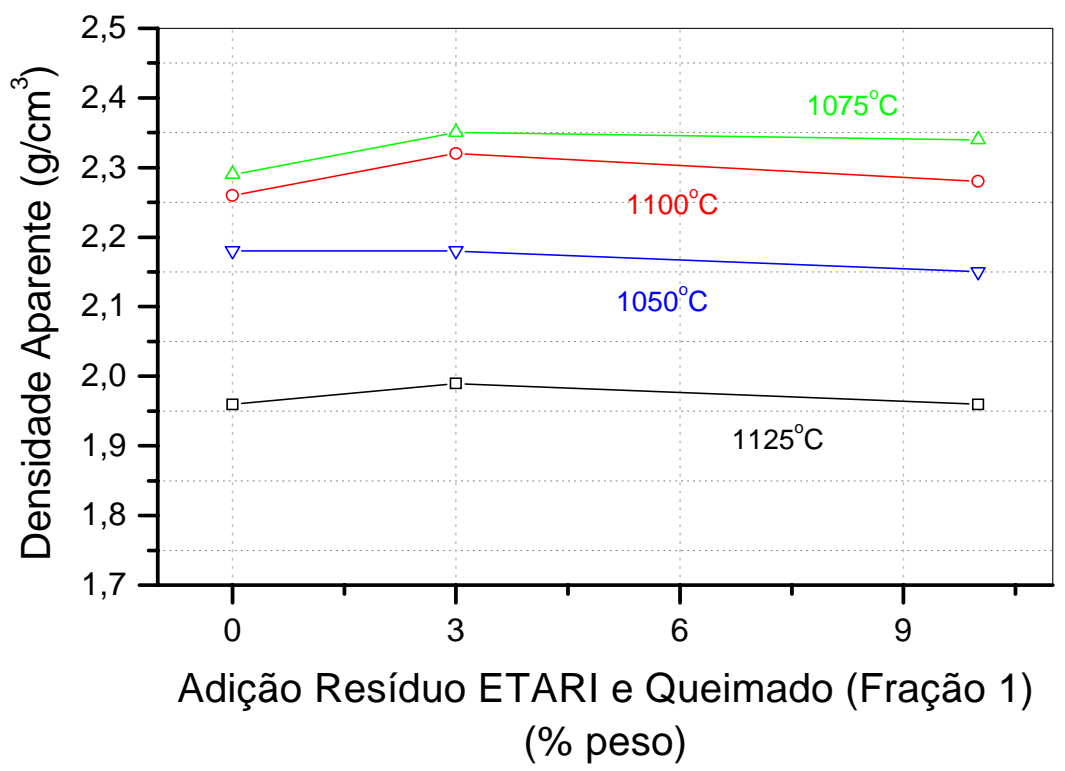

Figura 64: Densidade aparente de amostras queimadas de massa cerâmica contendo adição conjunta em peso de resíduos de ETARI e Queimado fração 1.

Com essas considerações é possível recomendar a adição conjunta dos resíduos de ETARI e Queimado Fração 1, em porcentagens de 3\% em peso cada, sendo queimado na temperatura de $1100^{\circ} \mathrm{C}$, para se obter os melhores resultados de resistência mecânica, o que não impede a obtenção de placas com a adição conjunta de 3\% dos resíduos em temperaturas menores, com valores que satisfaçam as normas de qualidade das placas. 


\subsection{AVALIAÇÃO TECNOLÓGICA DA INCORPORAÇÃO DOS RESÍDUOS À MASSA CERÂMICA}

\subsection{Resíduos de ETARI.}

Os resíduos de ETARI influenciam as propriedades mecânicas de muitas maneiras, devido à sua natureza química formadora de fase líquida em altas temperaturas e granulometria próxima á da massa cerâmica padrão.

Quanto à adição de resíduo, a massa cerâmica não apresenta um aumento significativo do módulo de flexão, devido ao acréscimo da quantidade de material vítreo na sua composição, promovendo o aumento de poros fechados que podem gerar tensões internas no material, resultando no surgimento de trincas e diminuindo a resistência mecânica, embora esses resíduos, contendo cátions como Zn, Li, Mg, Fe atuem como facilitador da nucleação de mulita, que confere maior resistência mecânica à peça (FERRARI, 2000).

Quando se analisam as peças queimadas em $1075^{\circ} \mathrm{C}$ e $1125^{\circ} \mathrm{C}$, contendo a mesma quantidade de resíduo de ETARI, o efeito da expansão da peça acima da temperatura de máxima gresificação sobre a absorção de água tem pouca influência, sendo observada uma variação muito pequena. A influência sobre a retração linear seco-queimado é significativa, sua alteração é em torno de $3 \%$, porém o efeito é bastante pronunciado em relação ao módulo de resistência à flexão, com alterações acima de $4 \%$.

A temperatura de início de expansão é diminuída de $1100^{\circ} \mathrm{C}$ na massa cerâmica “pura”, para $1075^{\circ} \mathrm{C}$ na mistura contendo $10 \%$ do resíduo, porém a intensidade desse efeito sobre as propriedades avaliadas não apresenta modificação com o aumento da porcentagem de resíduo de ETARI na massa cerâmica.

Após a análise de todas as principais propriedades, é possível apresentar as recomendações para o uso de uma quantidade adequada à temperatura de queima da massa cerâmica, de acordo com a tabela 16 , embora a temperatura de $1125^{\circ} \mathrm{C}$ não seja recomendada para a queima desse tipo de massa cerâmica. 
Tabela 16: Porcentagens recomendadas de adição de resíduo de ETARI à massa cerâmica, em função da temperatura de queima.

\begin{tabular}{|c|c|}
\hline $\begin{array}{c}\text { Temperatura Queima }\left({ }^{\circ} \mathrm{C}\right) \\
\text { Porcentagem resíduo adicionado } \\
(\%)\end{array}$ \\
\hline 1125 & Acima de 4 \\
\hline 1100 & 2 \\
\hline 1075 & 2 ou 3 \\
\hline 1025 & 2 \\
\hline
\end{tabular}

\subsection{Resíduos queimados fração 1.}

Ao avaliar as principais propriedades mecânicas das amostras contendo adições de resíduo queimado fração 1, é possível apresentar as recomendações para o uso de uma quantidade adequada à temperatura de queima da massa cerâmica, de acordo com a tabela 17. Essas porcentagens referem-se ao melhor desempenho entre as propriedades mecânicas estudadas. Quanto á temperatura de queima, a que apresentou melhores resultados foi a de $1100^{\circ} \mathrm{C}$, cuja porcentagem de absorção de água ficou abaixo dos 3\% e o módulo de resistência à flexão foi de 422,3 kgf/ $\mathrm{cm}^{2}$; com essas características, a placa pode ser classificada como BIb. Na temperatura de $1125^{\circ} \mathrm{C}$, as amostras obtiveram bons resultados, mas não compensariam o custo com energia térmica para efetuar a queima. As temperaturas mais baixas promovem peças com maiores porcentagens de absorção de água, particularmente a de $1050^{\circ} \mathrm{C}$, que permite a adição de apenas $2 \%$ em peso, para não exceder os valores de absorção de água, para a classificação da placa em BIIb. Embora a adição do resíduo prejudique as propriedades mecânicas em relação à massa cerâmica padrão, é possível obter placas cerâmicas com valores de absorção de água e módulo de resistência à flexão dentro dos limites estipulados para a classificação como BIIb, observando o caso limite do uso de $2 \%$ em peso para $1050^{\circ} \mathrm{C}$. 
Tabela 17: Porcentagens recomendadas de adição de resíduo queimado fração 1 à massa cerâmica, em função da temperatura de queima.

\begin{tabular}{|c|c|}
\hline Temperatura Queima $\left({ }^{\circ} \mathrm{C}\right)$ & $\begin{array}{c}\text { Porcentagem resíduo adicionado } \\
(\%)\end{array}$ \\
\hline 1125 & 2 \\
\hline 1100 & 2 \\
\hline 1075 & 2 \\
\hline 1025 & 2 \\
\hline
\end{tabular}

\subsection{Resíduos queimados fração 2 .}

Após avaliar as demais propriedades mecânicas, o módulo de resistência à flexão em 3 pontos das amostras queimadas contendo adições de resíduo queimado fração 2, apresentado na figura 58, observa-se que as melhores adições do resíduo, quando utilizadas as temperatura de $1050^{\circ} \mathrm{C}$ á $1100^{\circ} \mathrm{C}$, é $4 \%$ em peso, porque a granulometria do resíduo é menor, e, conseqüentemente, a área superficial é maior, portanto aumenta-se a reatividade química, o que faz a temperatura de densificação diminuir.

Desse modo, é possível aumentar a quantidade de resíduo na amostra. Para a temperatura de $1125^{\circ} \mathrm{C}$, a quantidade máxima é de $1 \%$ em peso, porque nessa temperatura ocorre a expansão da amostra, devido aos gases residuais e ao aparecimento de fases com maior coeficiente de expansão térmica.

Como a amostra densifica melhor com a adição de até 4\% do resíduo, quanto mais densa estiver a amostra, maior será a pressão dos gases e da microestrutura dessas fases que se expandem mais, levando a fragilização da amostra, assim, a pequena porcentagem desse resíduo, nessa temperatura, é a melhor recomendação.

Assim, as recomendações de uso dos resíduos queimados fração 2 são as seguintes:

a) utilizar no máximo 4\% em peso do resíduo para qualquer temperatura; 
b) a quantidade ideal é $2 \%$ em peso, por apresentar maior densidade aparente a seco, e estar próximo da quantidade que apresentou maior módulo de resistência a seco;

c) sinterizar as amostras em temperaturas mais baixas, uma vez que os resíduos com granulometria menor favorece a densificação nessas temperaturas.

\subsection{Resíduo de ETARI x resíduos queimados}

Comparando-se os efeitos da adição isolada dos resíduos de ETARI e queimados frações 1 e 2, sobre a retração linear (Figura 65), observa-se que, quando queimadas em $1125^{\circ} \mathrm{C}$, a adição dos resíduos queimados promove o aumento da retração linear seco-queimado em todas as adições, sendo que a adição de resíduo de ETARI favorece a retração linear nas amostras contendo $4 \%$ em peso, diminuindo para as adições maiores,. Em amostras queimadas em $1100^{\circ} \mathrm{C}$, o resíduo de ETARI, mesmo com sua característica de fundente, pode ser utilizado para controle dimensional das peças, uma vez que diminui a retração linear das amostras, quando adicionado até 3\% em peso, porque os resíduos de ETARI são fontes de calcita, que, na decomposição, gera fases com maior coeficiente de expansão e gases residuais.

Quando a queima é realizada em $1075^{\circ} \mathrm{C}$, a adição dos resíduos queimados promove uma diminuição da retração linear, o que pode ser interessante como meio de se controlar as dimensões da peça, enquanto que a adição do resíduo de ETARI promove uma retração linear ainda maior do que a da massa cerâmica padrão.

Em $1050^{\circ} \mathrm{C}$, os resíduos queimados promovem uma diminuição da retração linear, devido à temperatura insuficiente para promover a densificação da amostra contendo maior quantidade de material inerte. Em $1025^{\circ} \mathrm{C}$ os resíduos de ETARI aumentam a retração linear, por promover a formação de fase líquida, aumentando a capacidade de transporte de massa, conseqüentemente, densificação.

Em resumo, quando altas temperaturas são utilizadas e se deseja maior retração linear da peça, é recomendável utilizar os resíduos queimados frações 1 e 2, independentemente da diferença de granulometria entre os dois e, se o desejo é de menor retração da peça, deve-se usar os resíduos de ETARI. 
Em temperatura média $\left(1100^{\circ} \mathrm{C}\right)$, os resíduos queimados, principalmente a fração 2, promovem maior retração linear seco-queimado quando adicionados acima de 4\% em peso, e a menor retração é obtida com os resíduos de ETARI em adições de 2 ou $3 \%$ em peso.

Em temperatura de $1075^{\circ} \mathrm{C}$, a maior retração é conseguida utilizando-se os resíduos de ETARI em todas as quantidades (quanto maior a porcentagem adicionada, maior a retração linear obtida nessa temperatura).

Em $1050^{\circ} \mathrm{C}$, a adição de resíduos (qualquer tipo) diminui a retração linear em relação à massa padrão, comprometendo o processo de gresificação. Em $1025^{\circ} \mathrm{C}$, a adição de resíduo de ETARI aumenta a retração linear e ajuda o processo de gresificação.
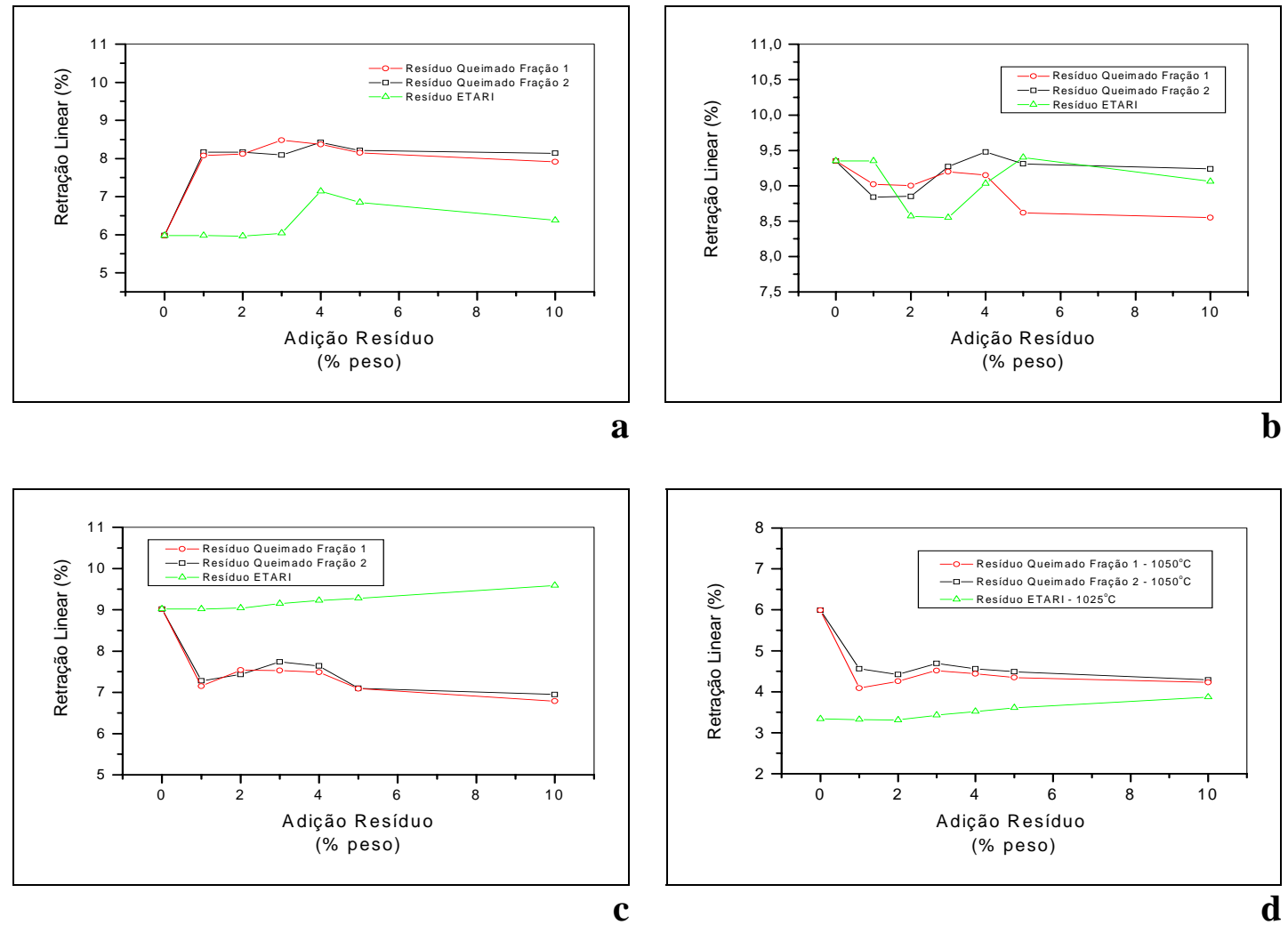

Figura 65: Retração linear seco-queimado de amostras de massa cerâmica contendo adições em peso de resíduos de ETARI e queimado frações 1 e 2; (a) $1125^{\circ} \mathrm{C}$, (b) $1100^{\circ} \mathrm{C}$, (c) $1075^{\circ} \mathrm{C}$, (d) $1050^{\circ} \mathrm{C}$. 
A absorção de água das amostras queimadas em $1125^{\circ} \mathrm{C}$ foi maior nas amostras que contêm os resíduos queimados fração 1, uma vez que sua granulometria grosseira dificulta a densificação, resultando em maior quantidade de poros, portanto, maior capacidade de absorção de água; os resíduos de ETARI promovem uma melhor densificação, apresentando uma menor porcentagem de absorção de água.

Para as amostras queimadas em $1100^{\circ} \mathrm{C}$, as amostras contendo até $4 \%$ de resíduo queimado fração 1 possuem, praticamente valores iguais de absorção de água, coincidindo com as amostras contendo os resíduos fração 2, já as amostras contendo os resíduos de ETARI possuem baixas absorções de água.

A versatilidade desses sistemas, onde é possível escolher a temperatura e a adição do resíduo mais adequado, para promover as melhores propriedades, é muito grande. Nesse sentido é possível analisar o módulo de resistência a flexão em 3 pontos para a temperatura de $1125^{\circ} \mathrm{C}$, onde se observa o melhor desempenho das amostras contendo resíduo queimado fração 1, para adições até $3 \%$ em peso, o motivo para esse comportamento já foi descrito anteriormente. Em $1100^{\circ} \mathrm{C}$ o melhor resíduo é o queimado fração 2, por ser mais refratário e por ter grãos um pouco maiores do que os da massa, ele atua como uma barreira ao crescimento dos grãos, reforçando a microestrutura por mecanismo de dispersão.

Em $1075^{\circ} \mathrm{C}$ e $1050^{\circ} \mathrm{C}$, os resíduos frações 1 e 2 produzem valores de absorção de água muito próximos e cada vez maiores do que os da massa cerâmica, indicando que a temperatura ainda não é a suficiente para iniciar a densificação. Em $1075^{\circ} \mathrm{C}$ e $1025^{\circ} \mathrm{C}$, os resíduos de ETARI diminuem a absorção linear das amostras, sem alterar bruscamente as características da massa cerâmica padrão.

Em $1075^{\circ} \mathrm{C}$, o melhor resíduo foi o de ETARI, por promover a densificação do material. Em $1050^{\circ} \mathrm{C}$, se a opção for uma adição de $2 \%$ em peso de resíduo, este deve ser o queimado fração 1, mas se for uma adição de 4\% em peso, então o resíduo deve ser o queimado fração 2 . Se quiser diminuir a temperatura para $1025^{\circ} \mathrm{C}$ e obter resultados dentro das especificações para classificação BIIb, é recomendável utilizarse $2 \%$ em peso do resíduo de ETARI.

Assim, dependendo da temperatura de queima, do tipo de produto desejável, do resíduo disponível, pode-se consultar as figuras 65, 66 e 67, para escolher a 
melhor alternativa para o processamento cerâmico com reciclagem interna de resíduos.

Com relação à absorção de água e módulo de resistência à flexão, de todos os tipos e quantidades adicionadas de resíduos, bem como as temperaturas de queima, somente não se enquadram nos valores para a classificação como placa cerâmica tipo BIIb as adições acima de 4\% em peso de resíduo de ETARI queimadas em $1025^{\circ} \mathrm{C}$, e as adições acima de 3\% em peso do resíduo queimado fração 1 e $4 \%$ em peso do resíduo queimado fração 2 , queimadas em $1050^{\circ} \mathrm{C}$. As amostras queimadas acima de $1075^{\circ} \mathrm{C}$ possuem valores menores que os limites inferiores para a classificação como BIIb, podendo ser reclassificadas, de acordo com a tabela 18.

Tabela 18: Classificação das amostras cerâmicas contendo resíduos queimados frações 1, 2, e de ETARI.

\begin{tabular}{|c|c|c|c|}
\hline $\begin{array}{l}\text { Temperatura } \\
\text { Queima }\left({ }^{\circ} \mathrm{C}\right)\end{array}$ & $\begin{array}{l}\text { Tipo de resíduo } \\
\text { adicionado }\end{array}$ & $\begin{array}{c}\text { Quantidade de } \\
\text { resíduo adicionado } \\
\text { (\%) }\end{array}$ & $\begin{array}{c}\text { Classificação } \\
\text { ISO } 13006\end{array}$ \\
\hline \multirow[t]{3}{*}{1100} & $\begin{array}{l}\text { Resíduo queimado } \\
\text { fração } 1\end{array}$ & até 5\% & BIb \\
\hline & $\begin{array}{c}\text { Resíduo queimado } \\
\text { fração } 2\end{array}$ & até $10 \%$ & BIb \\
\hline & ETARI & até $10 \%$ & BIb \\
\hline \multirow[t]{3}{*}{1075} & $\begin{array}{l}\text { Resíduo queimado } \\
\text { fração } 1\end{array}$ & até 4\% & BIIa \\
\hline & $\begin{array}{c}\text { Resíduo queimado } \\
\text { fração } 2\end{array}$ & até 4\% & BIIa \\
\hline & ETARI & até $10 \%$ & BIb \\
\hline \multirow[t]{2}{*}{1050} & $\begin{array}{c}\text { Resíduo queimado } \\
\text { fração } 1\end{array}$ & até 3\% & BIIb \\
\hline & $\begin{array}{l}\text { Resíduo queimado } \\
\text { fração } 2\end{array}$ & até 4\% & BIIb \\
\hline 1025 & ETARI & até $10 \%$ & BIIb \\
\hline
\end{tabular}


Esses resultados evidenciam que a massa cerâmica em estudo possui excelente qualidade, pois mesmo em processo via-seco (que não proporciona uma homogeneidade apreciável), com a adição de resíduos, quando queimada em temperaturas maiores que a usual de fábrica (que fica ao redor de $1050^{\circ} \mathrm{C}$ ) apresentam propriedades de padrão superior ao da classificação habitual, o que sugere que a indústria pode não estar aproveitando todo o potencial da massa cerâmica.
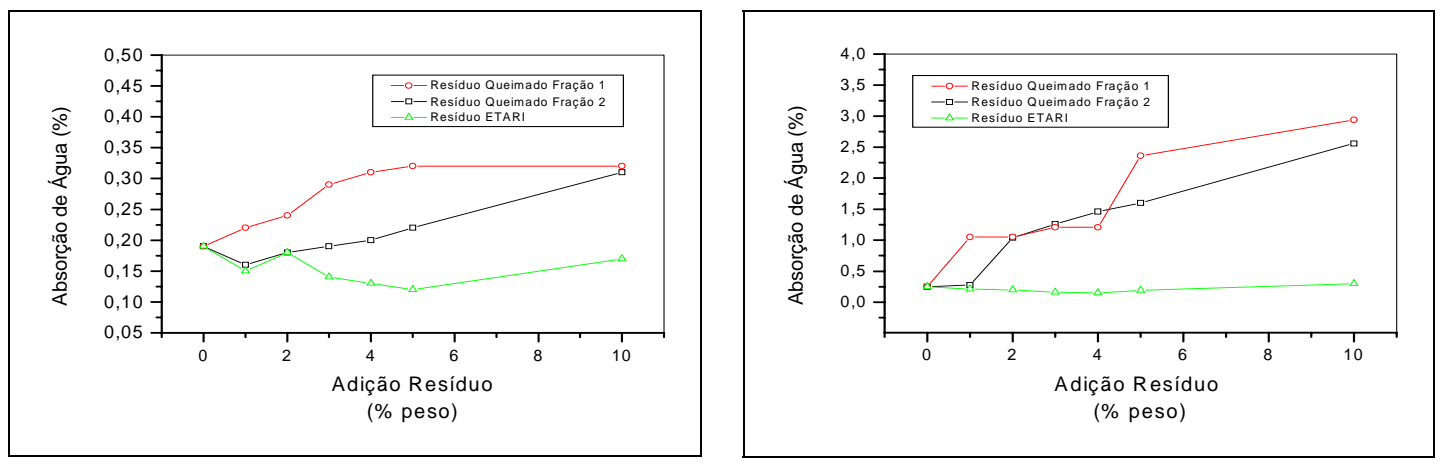

a
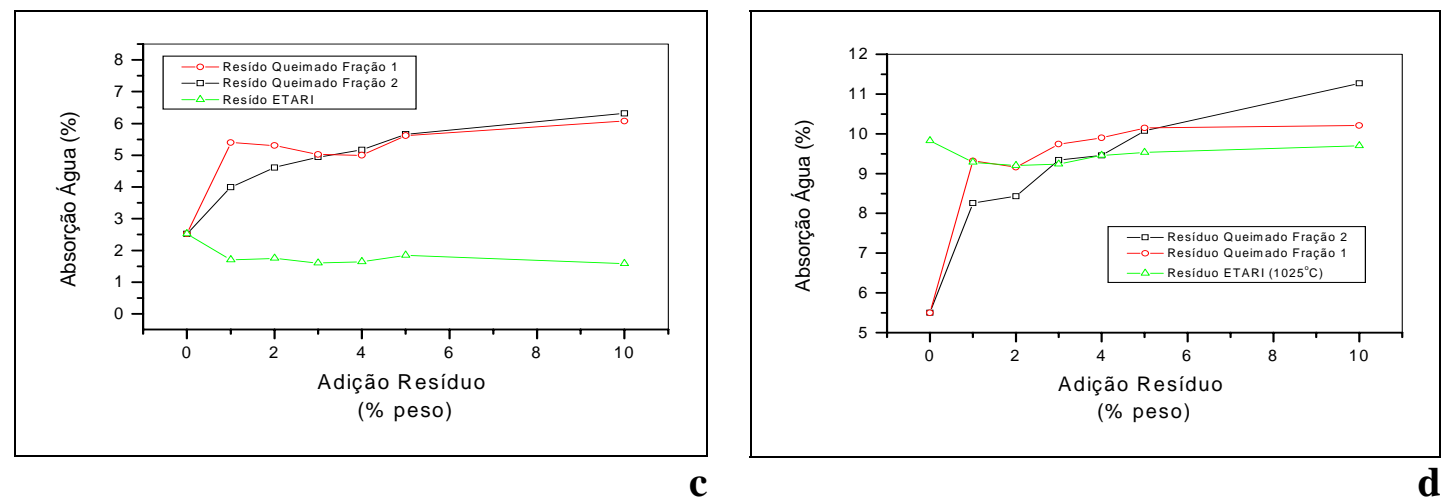

Figura 66: Absorção de água de amostras queimadas de massa cerâmica contendo adições em peso de resíduos de ETARI e queimado frações 1 e 2; (a) $1125^{\circ} \mathrm{C}$, (b) $1100^{\circ} \mathrm{C}$, (c) $1075^{\circ} \mathrm{C}$, (d) $1050^{\circ} \mathrm{C}$. 

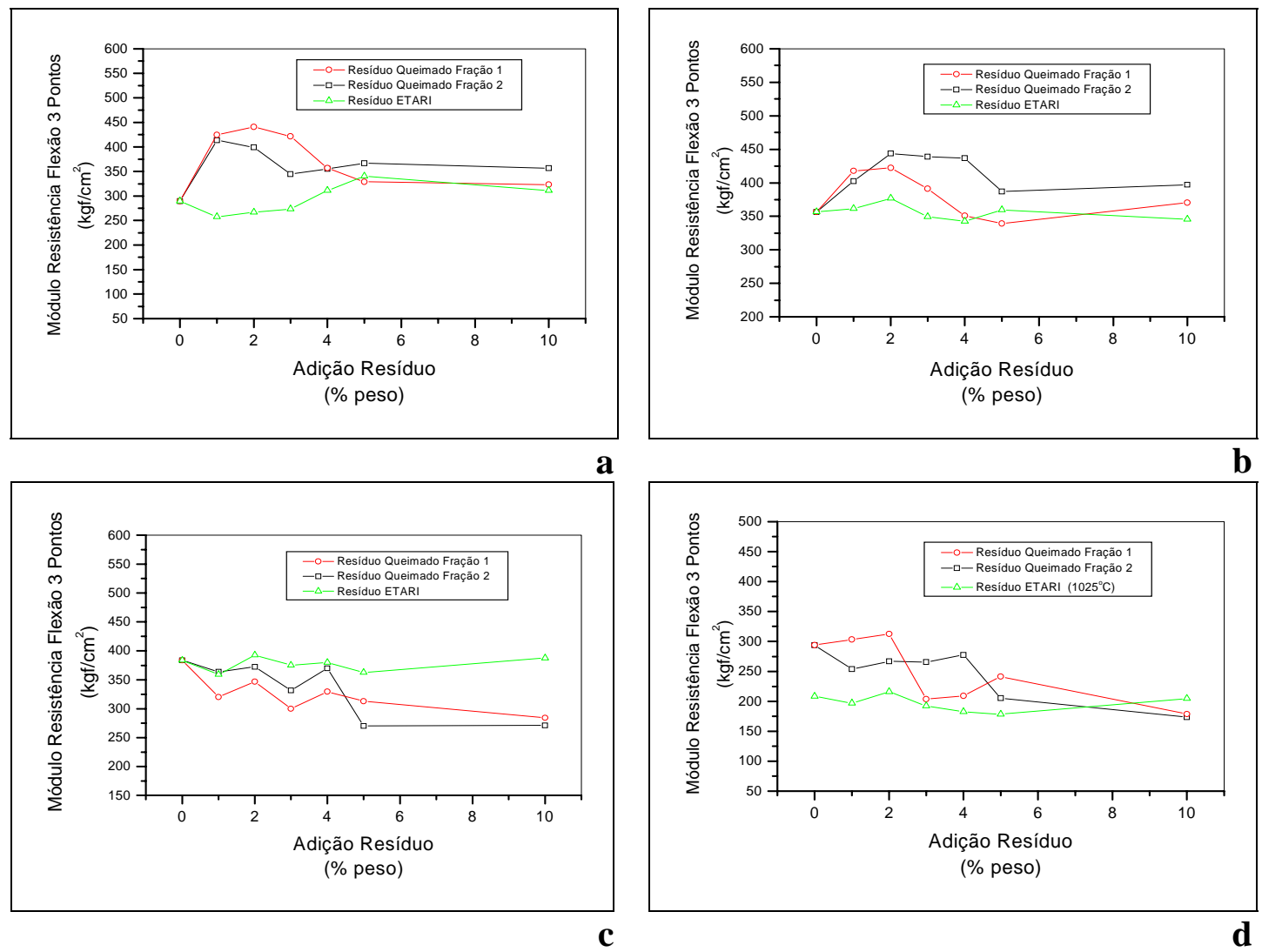

Fig. 67: Módulo resistência flexão 3 pontos de amostras queimadas de massa cerâmica contendo adições em peso de resíduos de ETARI e queimado frações 1 e 2; (a) $1125^{\circ} \mathrm{C}$, (b) $1100^{\circ} \mathrm{C}$, (c) $1075^{\circ} \mathrm{C}$, (d) $1050^{\circ} \mathrm{C}$.

No geral, recomenda-se a adição dos resíduos para se obter melhores resultados no desempenho mecânico de acordo com a tabela 19. A Incefra produz 0,15\% em peso de resíduo de ETARI e 0,77\% dos resíduos queimados, desse modo, é possível reciclar todo o resíduo sem promover alterações na qualidade da placa. 
Tabela 19: Recomendação geral de uso dos resíduos queimados frações 1, 2, e de ETARI por incorporação isoladamente à massa cerâmica padrão.

\begin{tabular}{|c|c|c|}
\hline $\begin{array}{l}\text { Temperatura } \\
\text { Queima }\left({ }^{\circ} \mathrm{C}\right)\end{array}$ & Tipo de resíduo adicionado & $\begin{array}{l}\text { Quantidade de resíduo } \\
\text { adicionado } \\
(\%)\end{array}$ \\
\hline \multirow[t]{3}{*}{1100} & Resíduo queimado fração 1 & $2 \%$ \\
\hline & Resíduo queimado fração 2 & $4 \%$ \\
\hline & ETARI & $1 \%$ \\
\hline \multirow[t]{3}{*}{1075} & Resíduo queimado fração 1 & $2 \%$ \\
\hline & Resíduo queimado fração 2 & $4 \%$ \\
\hline & ETARI & $2 \%$ \\
\hline \multirow[t]{2}{*}{1050} & Resíduo queimado fração 1 & $2 \%$ \\
\hline & Resíduo queimado fração 2 & $4 \%$ \\
\hline 1025 & ETARI & $3 \%$ \\
\hline
\end{tabular}

\subsection{Adição isolada $x$ adição conjunta dos resíduos.}

O efeito da adição isolada e conjunta dos resíduos à massa cerâmica é apresentado na figura 68.

Quando se realiza a adição conjunta dos resíduos, ocorre um balanço granulométrico entre a mistura da massa cerâmica, dos resíduos de ETARI e dos resíduos queimados, resultando em uma placa mais compacta. Essa nova granulometria, associada à capacidade do resíduo de ETARI em gerar gases durante a queima, dificultam a saída e/ou absorção desses gases, causando uma menor retração linear seco-queimado das placas em $1125^{\circ} \mathrm{C}$. Esse efeito é bem menos pronunciado em $1100^{\circ} \mathrm{C}$. 


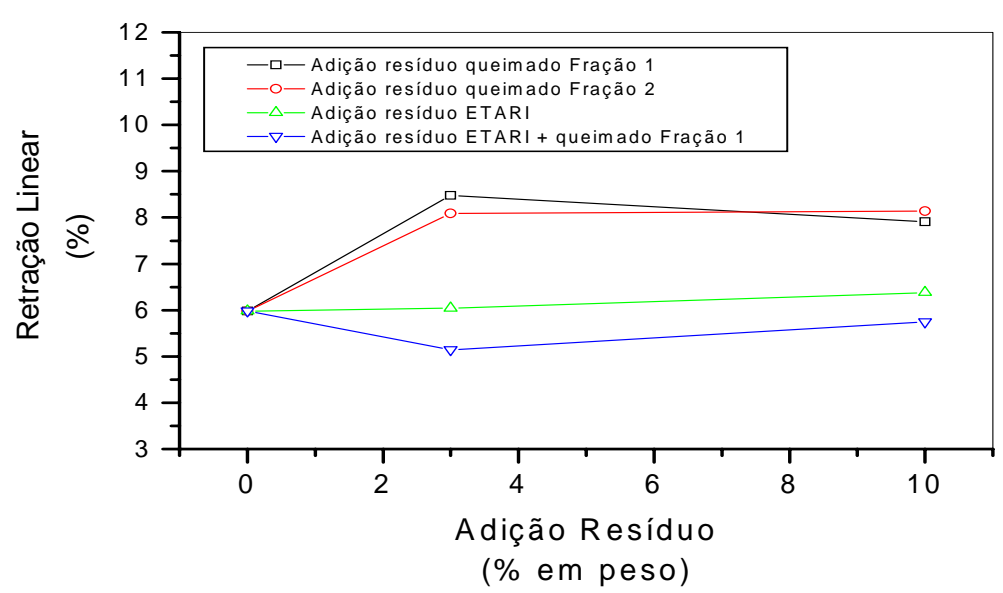

Figura 68a: Retração Linear de amostras de massa cerâmica queimadas em $1125^{\circ} \mathrm{C}$, contendo adições de modo isolado e conjunto dos resíduos de ETARI e queimados frações 1 e 2.

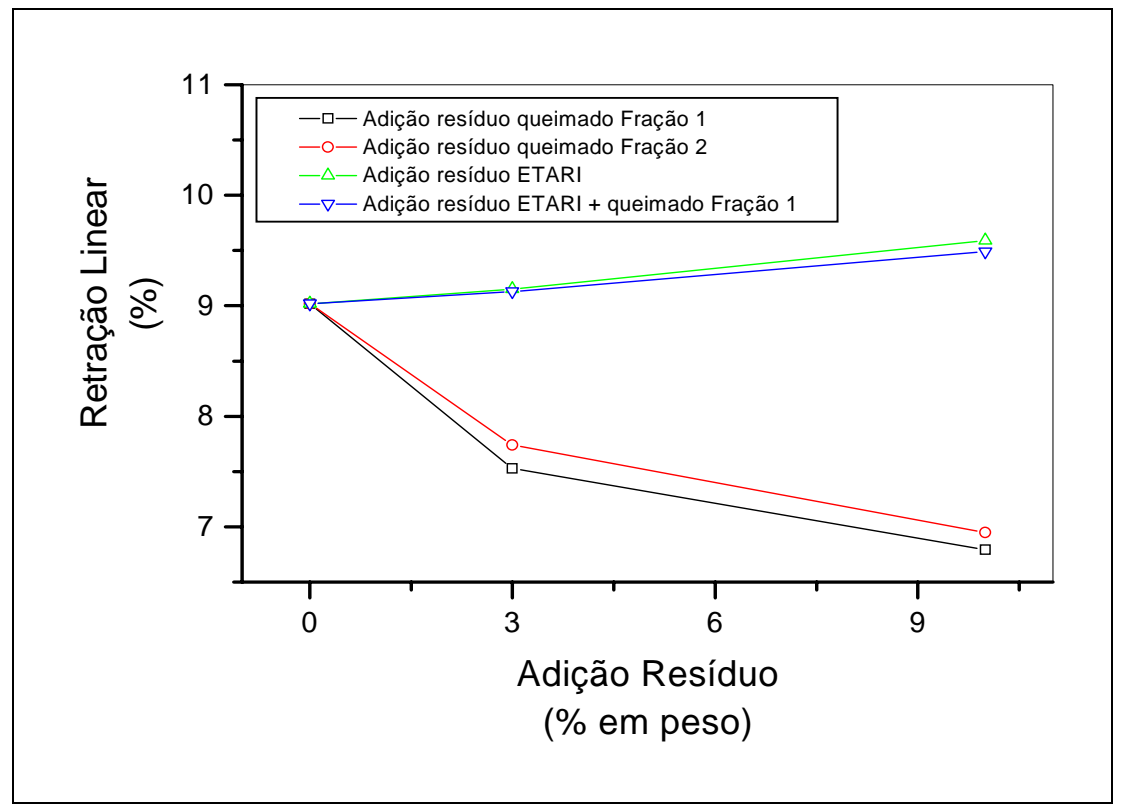

Figura 68b: Retração Linear seco-queimado de amostras de massa cerâmica queimadas em $1100^{\circ} \mathrm{C}$, contendo adições de modo isolado e conjunto dos resíduos de ETARI e queimados frações 1 e 2 . 


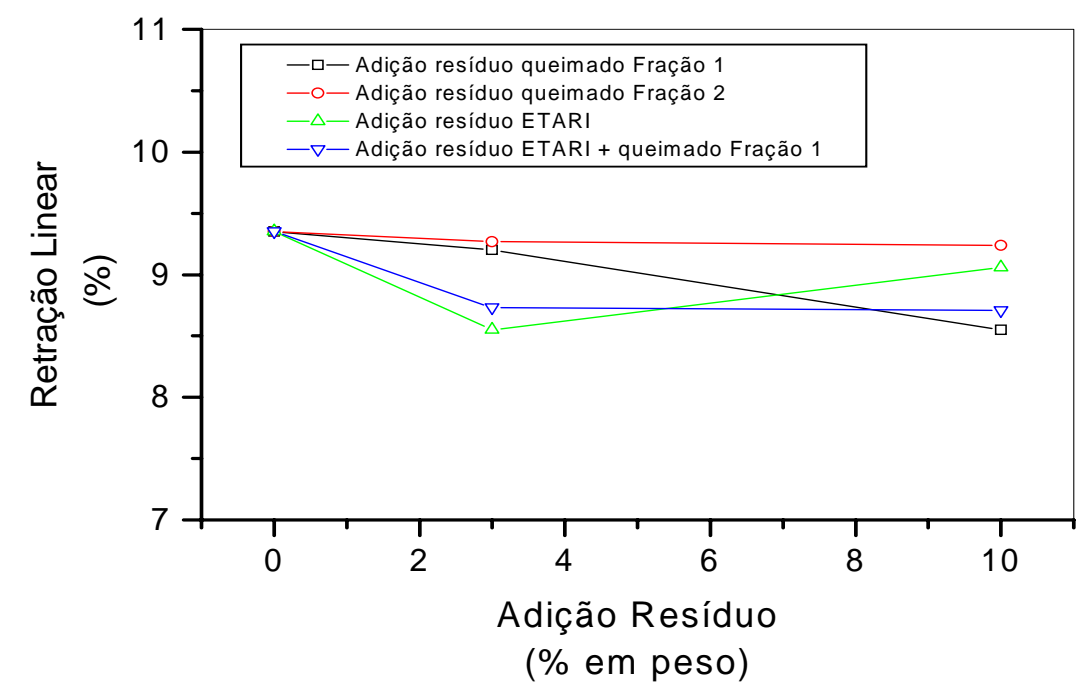

Figura 68c: Retração Linear seco-queimado de amostras de massa cerâmica queimadas em $1075^{\circ} \mathrm{C}$, contendo adições de modo isolado e conjunto dos resíduos de ETARI e queimados frações 1 e 2.

No geral, o comportamento da retração linear seco-queimado na adição conjunta segue o comportamento da adição isolada do resíduo de ETARI. Em altas temperaturas promove baixa retração linear e em baixas temperaturas promove retrações lineares próximas à retração linear da massa cerâmica padrão.

É interessante observar que, ao se adicionarem os resíduos em mesma proporção, mas em quantidades diferentes, os efeitos sobre as propriedades das peças cerâmicas padrão não variam consideravelmente, quando sinterizadas em temperaturas entre $1050^{\circ} \mathrm{C}$ e $1075^{\circ} \mathrm{C}$.

Um comportamento similar ao da retração linear é observado para a absorção de água (Figura 69). 


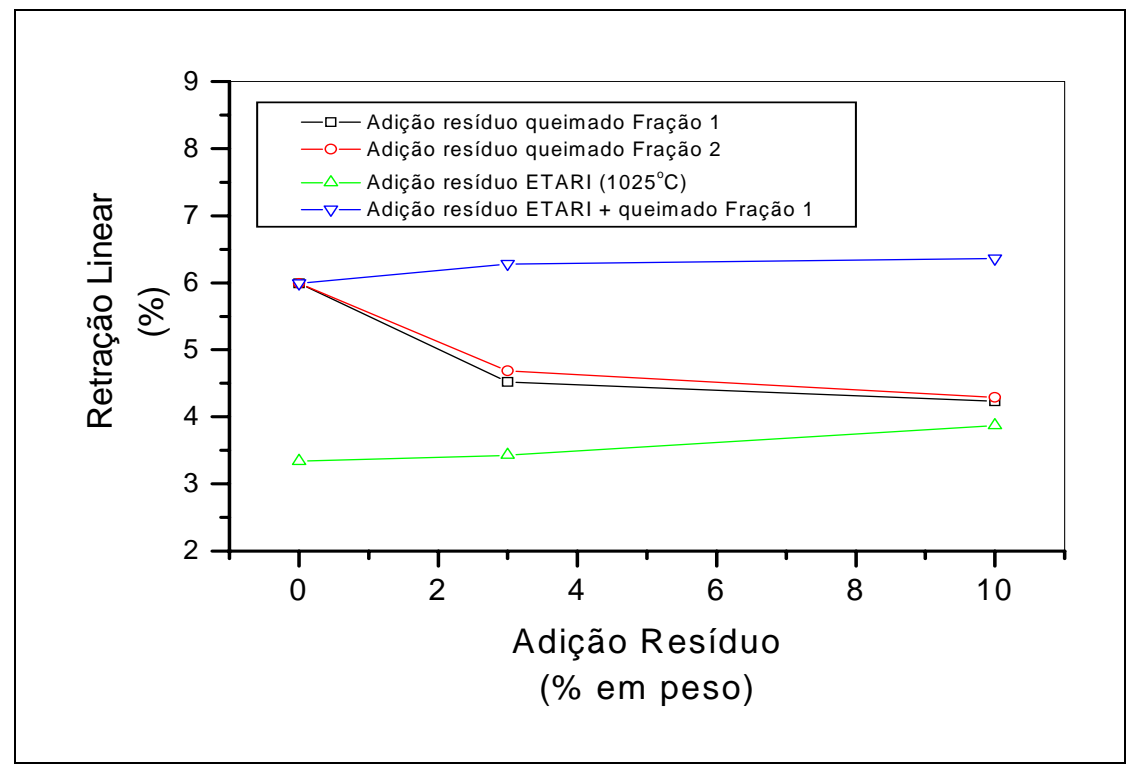

Figura 68d: Retração Linear de amostras de massa cerâmica queimadas em $1050^{\circ} \mathrm{C}$ contendo adições de modo isolado e conjunto dos resíduos de ETARI e queimados frações 1 e 2.

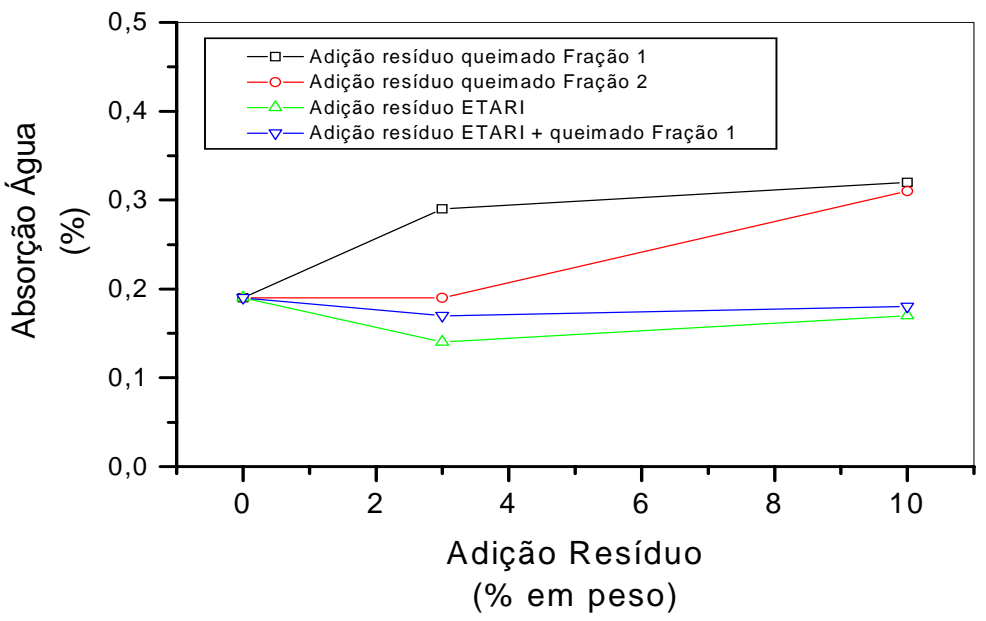

Figura 69a: Absorção de água de amostras de massa cerâmica queimadas em $1125^{\circ} \mathrm{C}$, contendo adições de modo isolado e conjunto dos resíduos de ETARI e queimados frações 1 e 2. 


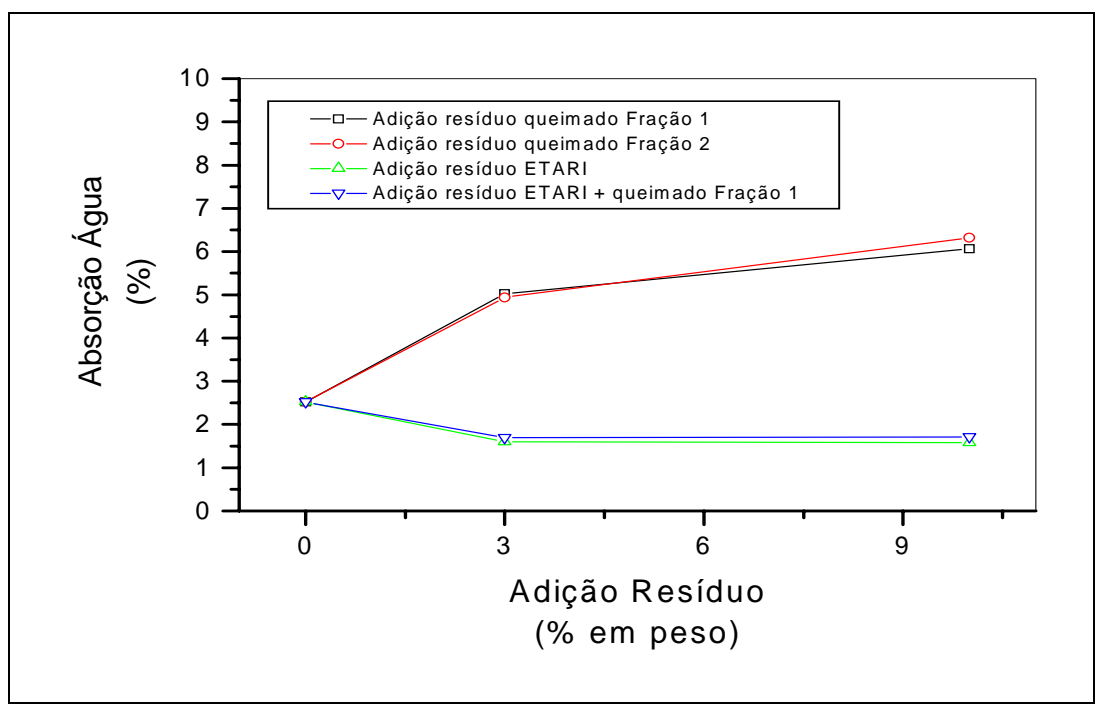

Figura 69b: Absorção de água de amostras de massa cerâmica queimadas em $1100^{\circ} \mathrm{C}$, contendo adições de modo isolado e conjunto dos resíduos de ETARI e queimados frações 1 e 2.

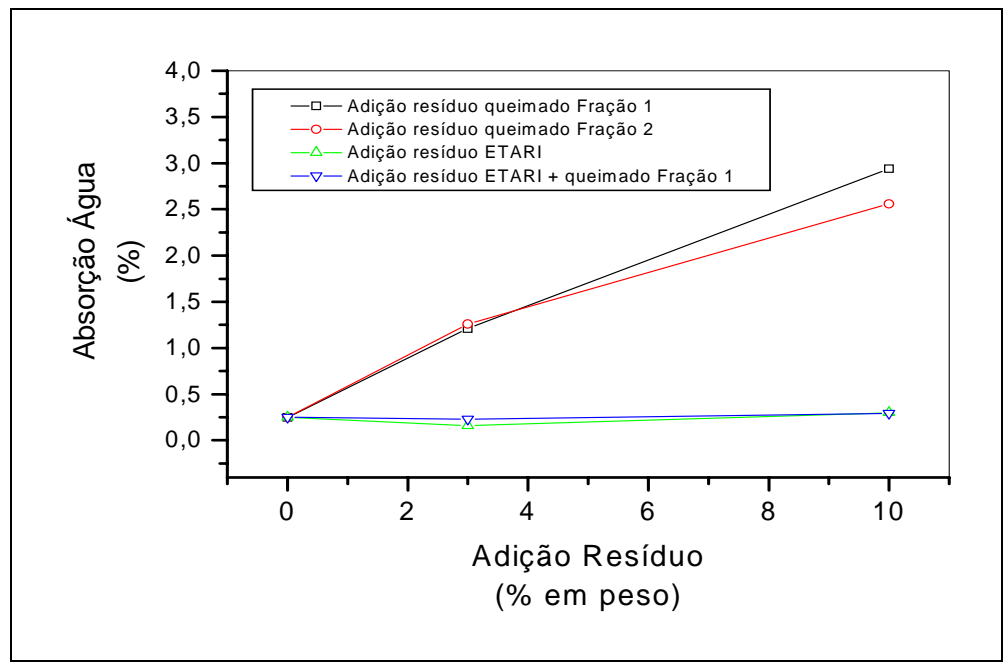

Figura 69c: Absorção de água de amostras de massa cerâmica queimadas em $1075^{\circ} \mathrm{C}$, contendo adições de modo isolado e conjunto dos resíduos de ETARI e queimados frações 1 e 2. 


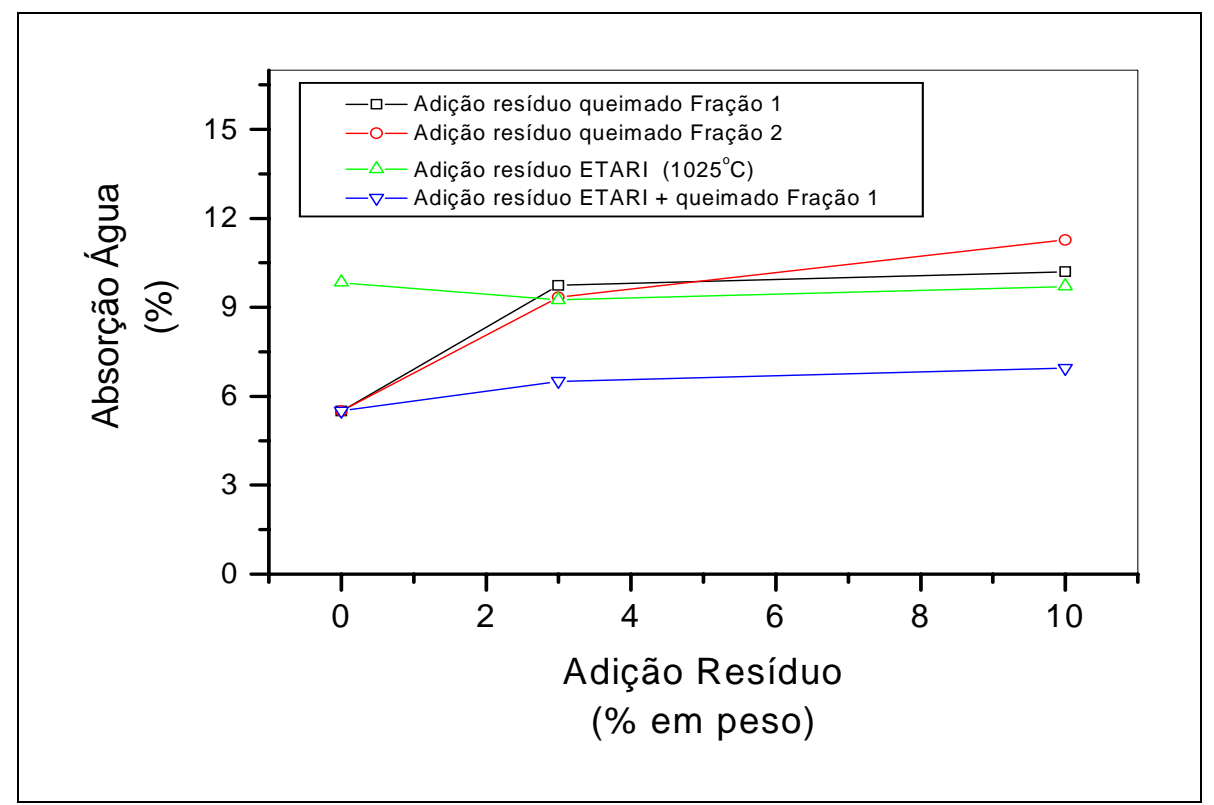

Figura 69d: Absorção de água de amostras de massa cerâmica queimadas em $1050^{\circ} \mathrm{C}$, contendo adições de modo isolado e conjunto dos resíduos de ETARI e queimados frações 1 e 2 .

Embora a adição conjunta siga o comportamento da adição isolada de resíduo de ETARI para as outras propriedades, observa-se na figura 70 que o módulo de resistência à flexão apresenta valores intermediários aos dos resíduos queimados e resíduos de ETARI adicionados isoladamente, quando sinterizados em $1125^{\circ} \mathrm{C}$ e apresentam os maiores valores quando as placas são sinterizadas em $1100^{\circ} \mathrm{C}, 1075^{\circ} \mathrm{C}$ e $1050^{\circ} \mathrm{C}$, sendo, nessa última, muito próximos do valor da massa cerâmica padrão. 


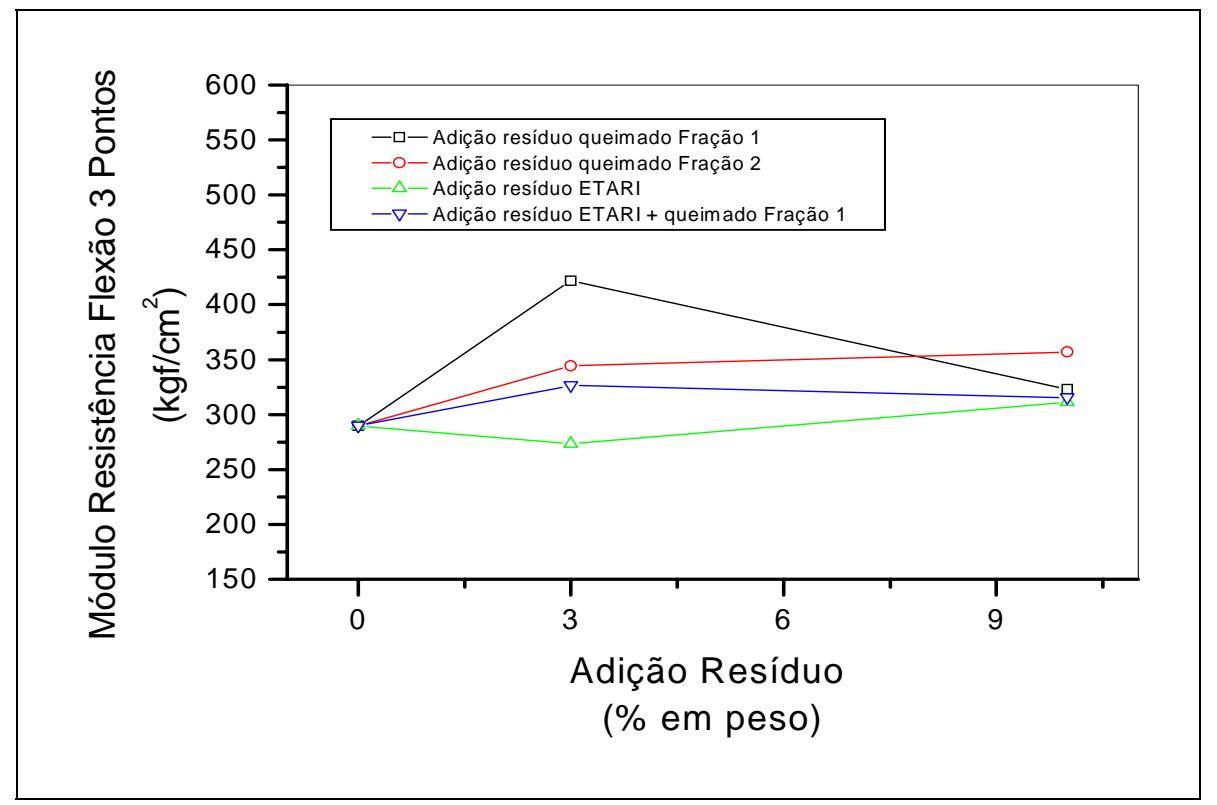

Figura 70a: Módulo de resistência à flexão 3 pontos de amostras queimadas em $1125^{\circ} \mathrm{C}$, de massa cerâmica contendo adições de modo isolado e conjunto dos resíduos de ETARI e queimados frações 1 e 2.

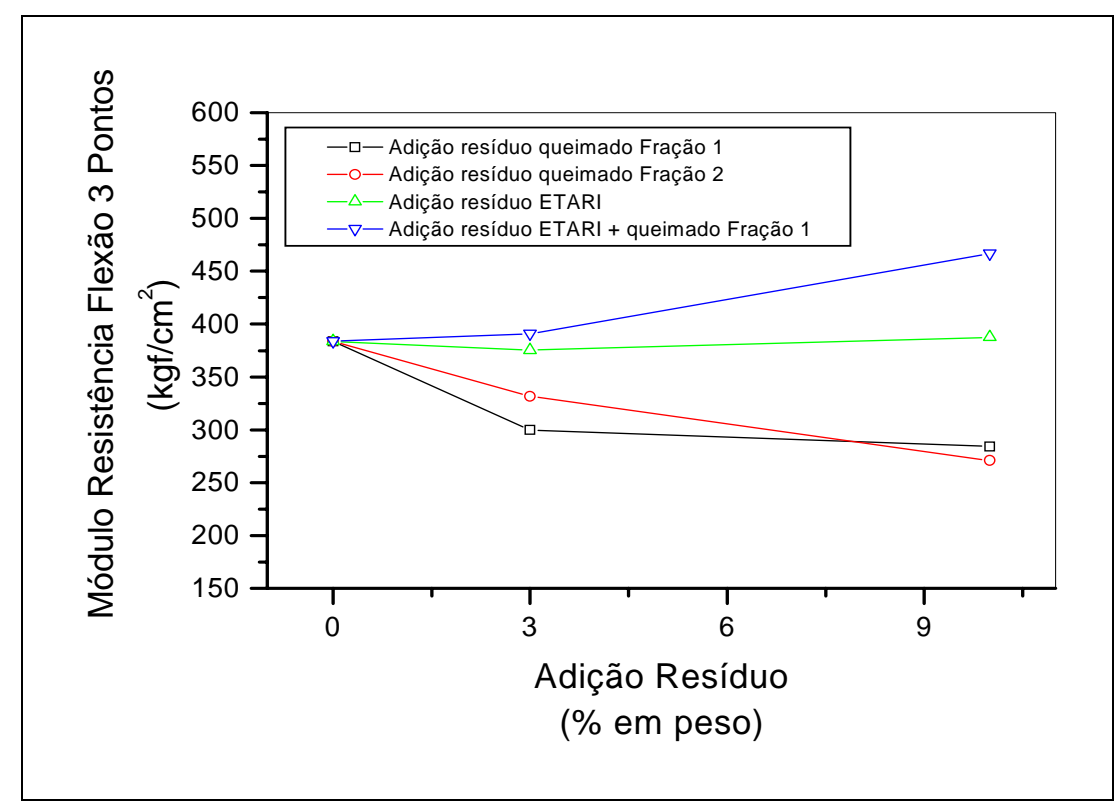

Figura 70b: Módulo de resistência à flexão 3 pontos de amostras queimadas em $1100^{\circ} \mathrm{C}$, de massa cerâmica contendo adições de modo isolado e conjunto dos resíduos de ETARI e queimados frações 1 e 2. 


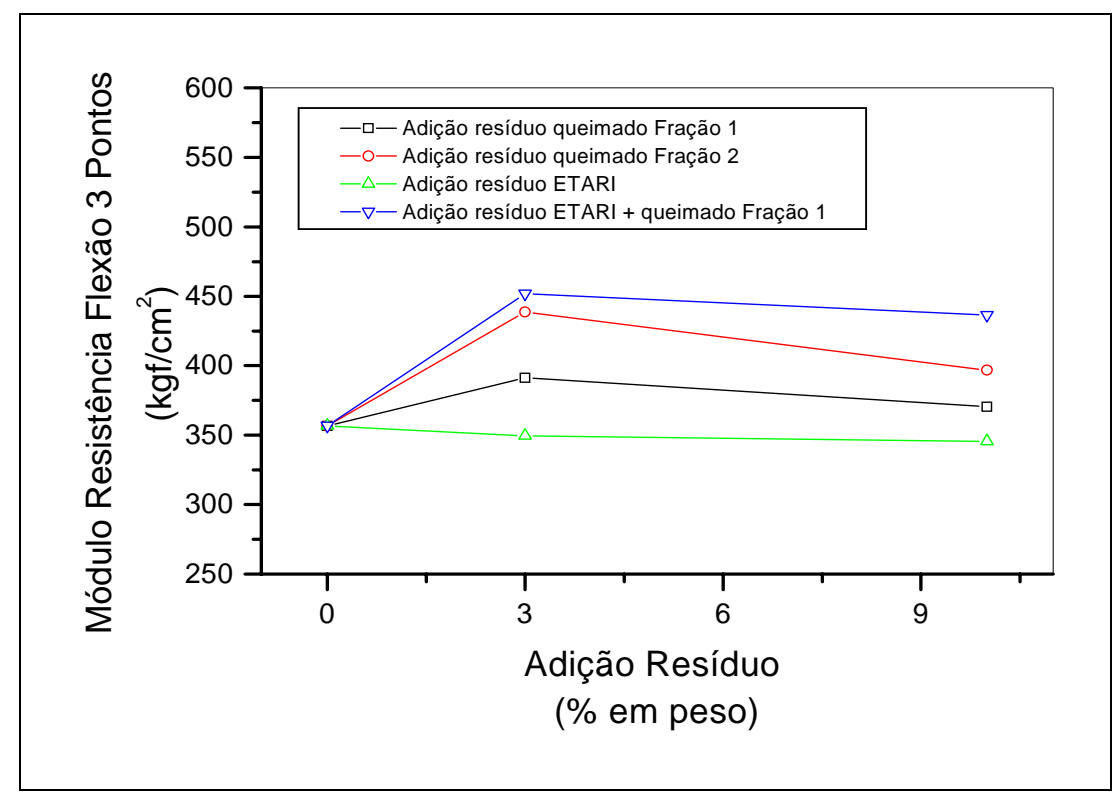

Figura 70c: Módulo de resistência à flexão 3 pontos de amostras queimadas em $1075^{\circ} \mathrm{C}$, de massa cerâmica contendo adições de modo isolado e conjunto dos resíduos de ETARI e queimados frações 1 e 2.

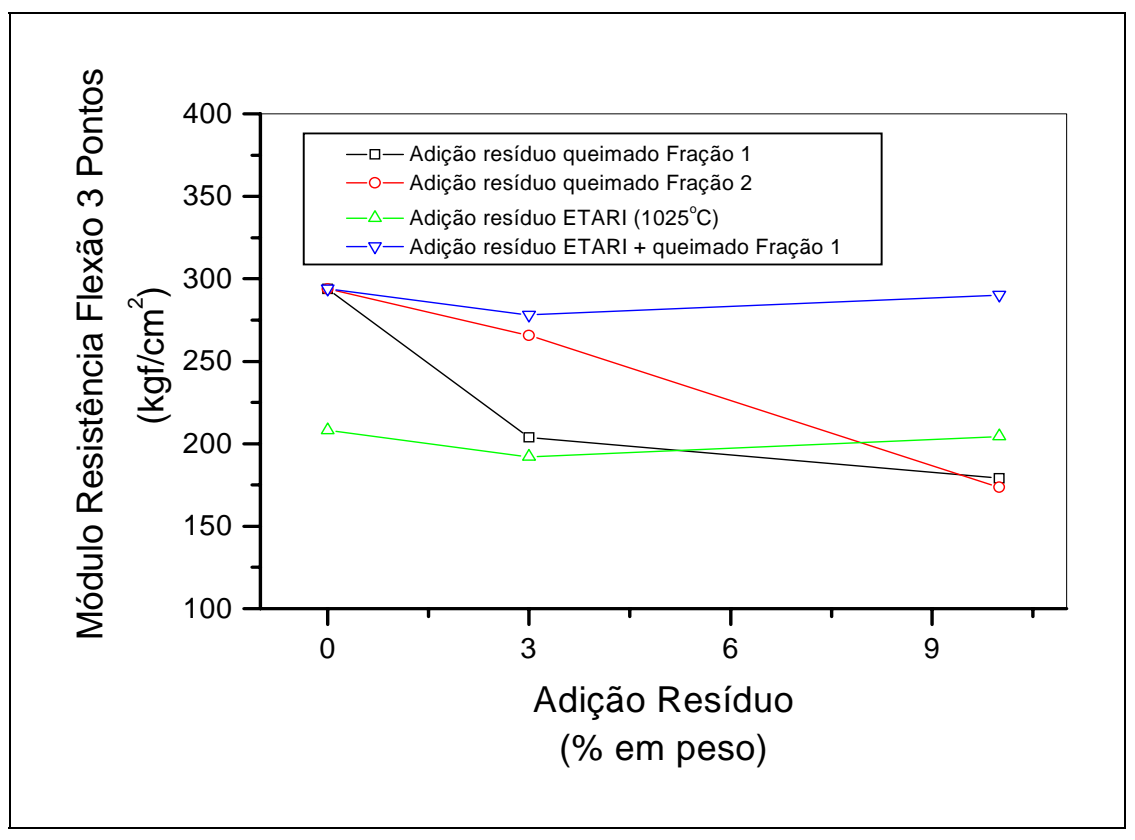

Figura 70d: Módulo de resistência à flexão 3 pontos de amostras queimadas em $1050^{\circ} \mathrm{C}$, de massa cerâmica contendo adições de modo isolado e conjunto dos resíduos de ETARI e queimados frações 1 e 2. 
Assim, quando se compara a adição isolada e conjunta dos resíduos, observa-se que a adição conjunta dos resíduos produz melhores resultados de resistência mecânica, sendo possível adições de quantidades maiores de resíduos, quando sinterizadas em $1050^{\circ} \mathrm{C}$ sem promover alterações significativas, desde que mantenha a proporção de 1:1 dos resíduos de ETARI e queimado. Essas alterações são de pequena intensidade, provavelmente devido a uma questão de balanço entre a quantidade de matéria inerte (resíduo queimado) e matéria vítrea (originada dos resíduos de ETARI).

Não foi realizado um controle dimensional das peças (determinação de empeno, curvatura, esquadro, etc), mas foi observado que a adição conjunta dos resíduos proporciona placas mais uniformes que as placas contendo adição isolada de resíduos de ETARI e queimados frações 1 e 2. Com relação à adição isolada, as placas contendo resíduos queimados apresentaram maior uniformidade dimensional. Essa uniformidade dimensional foi observada nas placas sinterizadas em temperaturas de $1050^{\circ} \mathrm{C}$ e $1075^{\circ} \mathrm{C}$.

Em temperaturas superiores foi observado o inchamento das placas, que foi maior naquelas contendo resíduos de ETARI. 


\section{CONCLUSÕES}

Com o desenvolvimento da pesquisa, pode-se concluir que:

1) Os resíduos de ETARI apresentaram toxicidade, sendo classificados como Classe I Tóxico (TL);

2) O ensaio de bioteste é mais sensível, porém a norma de classificação é mais tolerante quanto à toxicidade dos resíduos cerâmicos, comparando-se com o teste de lixiviação;

3) Os resíduos queimados foram considerados Classe I - Tóxico (TL), porque a concentração de cromo total excede os limites aceitáveis pela norma.

4) As amostras contendo $10 \%$ em peso de resíduos de ETARI e queimados fração 1 não apresentaram toxicidade, sendo classificados como Classe III - Inertes (TL);

5) Não foi detectada a presença de chumbo nas amostras queimadas contendo resíduo de ETARI, o que indica a ocorrência do processo de inertização do resíduo pela massa cerâmica ou a volatilização do chumbo durante a etapa de queima das placas cerâmicas;

6) Todos os resíduos sólidos cerâmicos originados na produção de placa cerâmica podem ser incorporados à massa cerâmica, desde que sejam adotados os procedimentos adequados a cada tipo de resíduo, tornando-se uma solução para a reutilização interna, que propicia o sistema de produção mais limpa, eliminando a necessidade de vertedouros de resíduos;

7) A adição isolada de pequenas quantidades de resíduo altera as propriedades da placa cerâmica, não sendo recomendável a utilização de quantidades acima de 5\% em peso;

8) É possível alterar os padrões de classificação das placas adicionando resíduos de ETARI ou queimados frações 1 e 2;

9) Com a adição isolada dos resíduos de ETARI é possível diminuir a temperatura de queima para $1025^{\circ} \mathrm{C}$, obtendo-se placas com classificação BIIb, economizando energia térmica, ou manter a temperatura em 1050, obtendo-se placas com classificação BIIa;

10) A adição conjunta dos resíduos é a melhor opção para a reciclagem, favorecendo a utilização de temperaturas de queima entre $1050^{\circ} \mathrm{C}$ e $1075^{\circ} \mathrm{C}$ e melhor desempenho mecânico; 
11) A quantidade de resíduos de ETARI e queimado fração 1, em adição conjunta, não causa alterações muito significativas, desde que sejam adicionados em proporção 1:1;

12) A adição conjunta dos resíduos proporciona peças mais uniformes em relação à adição isolada;

13) A placas com adição isolada dos resíduos queimados são mais uniformes do que as placas contendo adição isolada dos resíduos de ETARI;

14) É importante e fundamental reciclar os resíduos cerâmicos, pois se eliminam problemas com disposição de resíduos e com os órgãos de defesa ambiental, aumenta-se à economia com matérias-primas, com melhoria do sistema produtivo, e com a melhora da imagem da empresa, por estar produzindo bens de consumo, sem agredir o meio ambiente.

15) A reciclagem é tecnologicamente viável, sendo imprescindível que a indústria a coloque em prática. 


\section{SUGESTÕES PARA TRABALHOS FUTUROS}

Esse trabalho limitou-se a pesquisar formas de reutilização interna dos resíduos cerâmicos, como forma de eliminar os resíduos gerados. O ideal é que os resíduos não sejam criados. É necessária e de suma importância uma pesquisa que vise a prevenção à poluição, no tocante à minimização da geração de resíduos no processo produtivo das placas cerâmicas.

Podem ser sugeridas, também, ações de conscientização entre as empresas cerâmicas, a fim de que a prática de minimização da geração de resíduos e da reciclagem, embora pouco vantajosa em relação ao fator econômico empresarial (na visão do industrial), é muito valiosa no ponto de vista ambiental e social. 


\section{BIBLIOGRAFIA}

ALVES, W.A .; BALDO, J.B.; O potencial de utilização de um resíduo argiloso na fabricação de revestimento cerâmico- Parte II; Revista Cerâmica Industrial; 3 (1/2), Janl/Abril; 1998;

ASKELAND, D.R.; The science and engineering of materials; $3^{\text {th }}$ Edition, PWS Publishing Company; Boston, 1994;

ASSOCIAÇÃO NACIONAL DOS FABRICANTES DE CERÂMICA PARA REVESTIMENTO; www.anfacer.com.br, 09 set,2001;

ASSOCIAÇÃO NACIONAL DOS FABRICANTES DE CERÂMICA PARA REVESTIMENTO; www.anfacer.com.br, 15 fev,2002;

ASSOCIAÇÃO BRASILEIRA DE NORMAS TÉCNICAS - ABNT-; NBR 10005 Lixiviação de resíduos; 1987;

ASSOCIAÇÃO BRASILEIRA DE NORMAS TÉCNICAS - ABNT; NBR 10004 resíduos sólidos; 1987;

ASSOCIAÇÃO BRASILEIRA DE NORMAS TÉCNICAS - ABNT-; NBR 10007 amostragem de resíduos; 1987;

ASSOCIAÇÃO BRASILEIRA DE NORMAS TÉCNICAS - ABNT-; NBR 7181 -solo análise granulométrica; 1987;

ASSOCIAÇÃO ESPANHOLA DE FABRICANTES DE AZULEJOS E PAVIMENTOS CERÂMICOS - ASCER; Informe 2000: el sector español de fabricantres de baldosas cerámicas; http://www.ascer.es; novembro, 2001. 
ASSOZIAZONE NACIONALE DEI PRODUTTORI DI PIASTRELLE DI

CERAMICA; La depuracione delle acque nell'industria ceramica; Edicer; Bologna; 1988;

BARBA, A .; BELTRÁN, V.; FELIU, C.; GARCÍA, J.; GINÉS, F.; SÁNCHEZ, E.; SANZ, V.; Materias primas para la fabricación de soportes de baldosas cerámicas; Instituto de Tecnología Cerámica; Castellón; 1ª edición; 273-287; 1997;

BARCELÓ; O.A.C. et al..; Adición de residuos de piel curtida al cromo a pastas cerámicas; Técnica Cerámica; 187; 600-610; 1991;

BLASCO, A. et al; Tratamiento de emisiones gaseosas, efluentes líquidos y residuos sólidos de la industria cerámica; Associación de Investigación de las Industrias Cerámicas; Instituto de Tecnología Cerámica, Castellón, 1992;

BLASCO, A. et al.(b); Adición de fangos reciclados a composiciones de pavimentos y revestimientos cerámicos (I), Técnica Cerámica, 195; 470-483; 1992;

BRICKA, R.M.; HOLMES, T.T.; CULLINANE, M.J.JR.; A comparative evaluation of two extraction procedures: The TCLP and the EP proyect report EPA/600/2/049; Environmental Protection Agency - EPA; September 1991;

CAPELINI, M.; Proposta de minimização de resíduos em indústria de acabamento de metais: estudo de caso; São Carlos; 1999. Dissertação (mestrado), Escola de Engenharia de São Carlos, Universidade de São Paulo.

CARIDADE, M. D.; TORKOMIAN, A., L. V.; Estratégias de produção das empresas cerâmicas de Santa Gertrudes, Revista Cerâmica Industrial; 6 (1); 2001;

CARVALHO, A.B.M.; CARVALHO; M. A.B.; A determinação dos impactos e a gestão do desempenho social; Revista Meio Ambiente Industrial; ano IV-n ${ }^{0} 22$ - 23ํㅗㄹ ed.; 43 -52; jan/fev, 2000.

CENTRO CERÂMICO DO BRASIL - CCB; Catálogo técnico; 1999. 
CENTRO TECNOLÓGICO DE CERÂMICA E VIDRO; http://www.ctcv.pt, 04 nov, 2001;

CHAMLEY, H.; Clay sedimentology; Springer-Verlag; Germany; 1989;

CONSERVAÇÃO DE ENERGIA NA INDÚSTRIA CERÂMICA (manual de recomendações); Agrupamento de Engenharia Térmica - Divisão de Engenharia Mecânica - IPT; São Paulo, 1980;

COMPANHIA DE TECNOLOGIA E SANEAMENTO AMBIENTAL - CETESB; L5.018: Água- Teste de toxicidade aguda com Daphnia similis Claus, 1876 (Cladocera, Crustácea), agosto, 1999.

FIGUEREDO Fơ , P.M. et al.; - Projeto: plataforma para indústria brasileira de revestimento cerâmico- Ministério da Ciência e Tecnologia - PADCT III; (Relatório do Grupo Avaliação Ambiental)São Paulo; 1999.

FERRARI, K.R., FIGUEREDO F ${ }^{0}$, P.M., MACHADO, L.A. e PASCHOAL, J.O.A.; Transformações das matérias-primas do suporte durante a queima de revestimento cerâmico; Revista Cerâmica Industrial; 5 (2) Março/Abril; 2000;

FERRARI, K.R., FIGUEREDO F ${ }^{\underline{0}}$, P.M., MACHADO, L.A. e PASCHOAL, J.O.A.; Normas técnicas e legislações ambientais para a indústria de revestimentos cerâmicos brasileira- Parte I: Normas técnicas ABNT; Revista Cerâmica Industrial; 5 (6); Nov/Dez; 2000;

FERRARI, K.R., FIGUEREDO F ${ }^{\underline{o}}$, P.M., MACHADO, L.A. e PASCHOAL, J.O.A.; Normas técnicas e legislações ambientais para a indústria de revestimentos cerâmicos brasileira- Parte II: Legislações ambientais; Revista Cerâmica Industrial; 6 (1) Jan/Fev; 2000; 
FLORÊNCIO, R.V.S.; As argilas do subgrupo itararé: potencialidades como matérias primas cerâmicas e como inertizadoras de resíduos industriais; Tese (Doutorado), Instituto de Geociências, USP; São Paulo; 1999.

GOMES, C.B. (coord.); Técnicas analíticas instrumentais aplicadas à geologia; Edgard Blücher Ltda.; São Paulo; 1984.

GOMES, C.L.S.P.; Crimes contra o meio ambiente: responsabilidade e sansão penal; Editora Oliveira Mendes; São Paulo; 1998.

GRIM, RALPH E.; Clay mineralogy; McGraw-Hill Co.;Second Edition; 1968;

IBAÑEZ, R. et al.; Caracterización de residuos tóxicos y peligrosos: influencia del ensayo de lixiviación; In: XXIV REUNIÓN BIENAL DE LA REAL SOCIEDAD ESPAÑOLA DE QUÍMICA; Anais, Málaga; 21-24 septiembre; 1992;

INSTITUTO DI RICERCHE TECNOLOGICHE PER LA CERAMICA; Il problema dei rifiuti solidi nell'industria ceramica: um modo diverso di smaltimento; Ceramurgia; 11(5); 200-202; 1981;

KINLAW, D. C.; Empresa competitiva e ecológica: desempenho sustentado na era ambiental; Trad. por Lenk Peres Alves de Araújo; Makron Books; São Paulo; 1997.

MACKENZI, R.C. (EDITOR); The differential thermal investigation of clays; Mineralogical Society; London; 1957;

MARINO, L.F.B. e BOSCHI, O.A.; A expansão térmica dos revestimentos cerâmicos Parte IV: Efeitos da adição da dolomita; Revista Cerâmica Industrial; 5 (1), Jan/Fev 2000;

MARTINS, C.A.; Propriedades reológicas de massas cerâmicas; Dissertação (Mestrado); Universidade Federal de São Carlos, São Carlos, 1986; 
MELO, M.A.; MELO, D.M.A.; NETO, G.S.; GALDINO, J.N.; Estudo da gresificação de argilas do $R N$ em processamento cerâmico; Anais do $45^{\circ}$ Congresso Brasileiro de Cerâmica; Ref. 0502301;Maio/Jun; 2001;

MINISTÉRIO DO DESENVOLVIMENTO URBANO E MEIO AMBIENTE; Código Nacional do Meio Ambiente - CONAMA- 20; 1986;

MONFORT, E. et al.; Caracterización de residuos de la industria azulejera; Técnica Cerámica; 195; 238-246; 1992;

MONFORT, E.; ENRIQUE, J.E.; Economia energética e vantagens meioambientais da reutilização de resíduos; Revista Cerâmica Industrial; Vol 1, ago/dez 1997;

MONFORT, E.; JOSÉ, M.J.; Legislación sobre residuos industriales aplicable a la industria cerámica; Revista Técnica Cerámica; 220; 36-46; 1998;

MOORE, D.M.; REYNOLDS-JR., R.C.; X-ray diffraction and the identification and analysis of clay minerals; Oxford University Press; second edition; New York; 1997;

MORENO, M.M.T.; CHRISTOFOLETTI, S.R. e VALARELLI, J.V.; Composição química dos elementos maiores em rochas sedimentares da formação Corumbataí e sua influência na produção de revestimentos cerâmicos; Revista Cerâmica Industrial; 5 (4), Jul/Ago 2000;

MORENO, M.M.T.; ROMANO, R.; Reaproveitamento dos rejeitos de engobe e esmalte nas massas para revestimentos cerâmicos; Anais do $45^{\circ}$ Congresso Brasileiro de Cerâmica; Ref. 0501201;Maio/Jun; 2001;

PIVA, M.A .; PACHECO, A.C.B.; O que as indústrias de revestimento cerâmico da região de Santa Gertrudes esperam das instituições de ensino, pesquisa e desenvolvimento; Revista Cerâmica Industrial; 2 (5/6), Set/Dez; 1997; 
PRICE, B.; Hazardous waste management: new regulation and new technology; Financial Times Business Information; London; 1990;

PROJETO ECOVALOR; http://www.eco.valor.pt; 18 abril, 2000;

REIS, M.; ISO 14000 - gerenciamento ambiental: um novo desafio para a sua competitividade; Qualitymark; São Paulo; 1996.

RICHERSON, D.W.; Modern ceramic engineering: properties, processing, and use in design ; Marcel Dekker, Inc.; New York; 1982;

SALEJ, S.B.; Os impactos da liberalização comercial sobre a qualidade ambiental dos

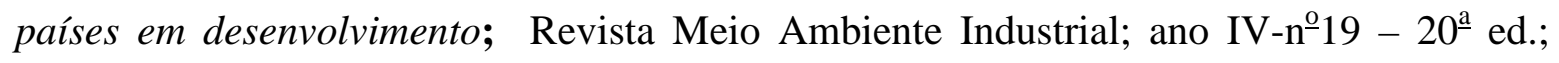
103-108; jul/ago 1999.

SANCHEZ, E.;: Formulação de massas para revestimentos cerâmicos;(Manual); Departamento Engenharia Materiais; UFSCar, São Carlos; 1997;

SANTOS, P.S.; Tecnologia das argila; Texto do curso de pós-graduação ministrado na Escola Politécnica da Universidade de São Paulo; 1966;

SCHALCH, V.; LEITE, W.C. A.; GOMES, L.P.; curso sobre gerenciamento de resíduos sólidos; Associação Brasileira de Engenharia Sanitária e Ambiental - ABES; Goiânia; jun. 1990.

SCHIMIT, N.; KODUCULAN, H.; Recovery, recycle and reuse of industrial waste; Lewis Publishers; Michigan; 1985.

SEIBEL, S.; MEYER-STAMER, J.; MAGGI, C.; Globalização e os desafios para as indústrias italiana, espanhola e brasileira de revestimentos cerâmicos; Revista Cerâmica Industrial; 6 (6), Nov/Dez 2001; 
UNITED STATE ENVIRONMENTAL PROTECTION AGENCY - US EPA; Profile of the metal fabrication industry; http://es.epa.gov/oeca/sector/index.html\#metal; 16 dec.; 1998.

VERNIER, J.; O meio ambiente; Trad. por Marina Appennzeller; Papirus, Campinas; 1994.

VIVONA, D., Visão, desafios e novos rumos da cerâmica de revestimento, Revista Cerâmica Industrial; 5 (2); 2001; 
